\author{
UNIVERSIDADE DE SÃO PAULO \\ ESCOLA DE ENGENHARIA DE SÃO CARLOS \\ DEPARTAMENTO DE ENGENHARIA DE PRODUÇÃO
}

CAMILA DOS SANTOS FERREIRA

\title{
Análise da relação entre normas de sistemas de gestão (ISO 9001, ISO 14001, OHSAS 18001 e NBR 16001) e a sustentabilidade empresarial.
}





\section{Análise da relação entre normas de sistemas de gestão (ISO 9001, ISO 14001, OHSAS 18001 e NBR 16001) e a sustentabilidade empresarial.}

Dissertação apresentada a Escola de Engenharia de São Carlos, da Universidade de São Paulo, como parte dos requisitos para obtenção do título de Mestre em Engenharia de Produção.

Área de Concentração: Processos e Gestão de Operações.

Orientador: Prof. Dr. Mateus Cecílio Gerolamo. 


\section{AUTORIZO A REPRODUÇÃO TOTAL OU PARCIAL DESTE TRABALHO, POR QUALQUER MEIO CONVENCIONAL OU ELETRÔNICO, PARA FINS DE ESTUDO E PESQUISA, DESDE DE QUE CITADA A FONTE.}

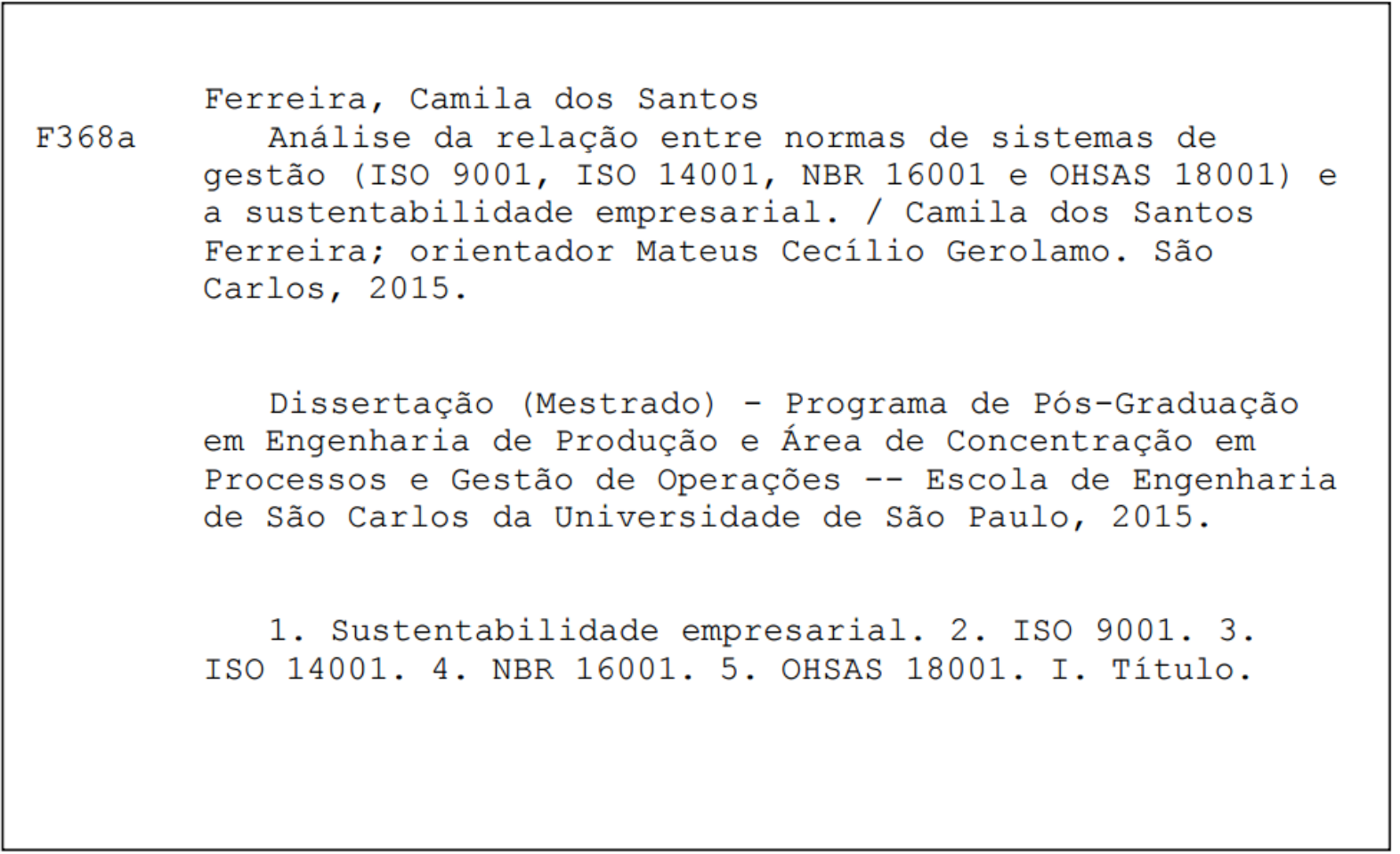




\section{FOLHA DE JULGAMENTO}

Candidata: Bacharel CAMILA DOS SANTOS FERREIRA.

Título da dissertaçāo: "Análise da relação entre normas de sistemas de gestāo (ISO 9001, ISO 14001, OHSAS 18001 e NBR 16001) e a sustentabilidade empresarial".

Data da defesa: 19/08/2015

Comissāo Julgadora:

Resultado:

Prof. Dr. Mateus Cecilio Gerolamo (Orientador)

ANPOVMO4

(Escola de Engenharia de São Carlos/EESC)

Profa. Dra. Érica Pugliesi

(Universidade Federal de São Carlos/UFSCar)

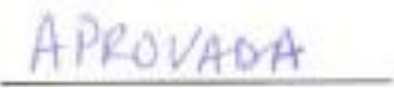

Prof. Titular Luiz Cesar Ribeiro Carpinetti

APRONADA

(Escola de Engenharia de São Carlos/EESC)

Coordenadora do Programa de Pós-Graduação em Engenharia de Produçāo:

Profa. Associada Daisy Aparecida do Nascimento Rebelatto

Presidente da Comissão de Pós-Graduação:

Prof. Associado Paulo César Lima Segantine 



\section{AGRADECIMENTOS}

Agradeço primeiramente a Deus pela vida e por ter colocado tantas pessoas boas em meu caminho, que de maneira direta ou indireta auxiliaram na realização de todos os meus sonhos até o momento. Agradeço ainda ao meu anjo da guarda e todos meus mentores espirituais por sempre girarem meu caminho na busca pelo bem.

Agradeço a minha família especialmente a minha mãe (Ailda dos Santos), minha irmã (Sabrina dos Santos Ferreira) e ao meu cachorro por sempre estarem do meu lado nos momentos mais difíceis e por sempre me apoiarem em minhas decisões. Agradeço também ao meu pai (Milton José Gonçalves Ferreira).

Agradeço ao meu amor e companheiro (Brayan Pétrick de Souza) pelos conselhos, paciência, dedicação, força, incentivo e amor durante essa caminhada.

Agradeço ao Prof. Dr. Mateus Cecílio Gerolamo por aceitar me orientar e por sempre tratar-me com muito respeito e atenção.

Agradeço a todos os meus amigos e colegas do Laboratório de Gestão de Operações que tive o prazer de trabalhar durante 2 anos em especial a Ana Laura, André, Camila (Xará), Carol, Carlos, Diego, Fábio, Lie, Micheli, Nadya, Paulinha e Thales.

Agradeço ao Departamento de Engenharia de Produção e a Escola de Engenharia de São Carlos pela disponibilização da infraestrutura necessária e a todos os funcionários que sempre me trataram muito bem.

Agradeço a Coordenação de Aperfeiçoamento de Pessoal de Nível Superior (CAPES) pelo financiamento da bolsa de mestrado.

Agradeço ao Prof. Dr. José Carlos Barbieri por participar da banca de qualificação desse trabalho e pelas valiosas contribuições.

Agradeço os membros da banca de defesa Profa. Dra. Érica Pugliesi pelo aceite em participar e contribuir no enriquecimento do trabalho e ao Prof. Dr. Luiz Cesar Ribeiro Carpinetti pela participação na banca de qualificação e pelo aceite em participar da banca de defesa.

Agradeço a todos os especialistas que aceitaram participar de minha pesquisa.

Por fim, agradeço à toda a sociedade brasileira que de forma indireta financiou esse trabalho. 



\section{RESUMO}

FERREIRA, C. S. Análise da relação entre normas de sistemas de gestão (ISO 9001, ISO 14001, NBR 16001 e OHSAS 18001) e a sustentabilidade empresarial. 2015. 148 p. Dissertação (Mestrado) - Escola de Engenharia de São Carlos, Universidade de São Paulo, São Carlos, 2015.

A sustentabilidade está sendo inserida no contexto empresarial como uma forma de minimizar os impactos causados pelos processos produtivos. Empresas estão deixando de considerar somente questões econômicas e passaram a atentarem-se as questões socioambientais. Diante desse contexto, as organizações utilizam ferramentas como normas de sistemas de gestão para auxiliar a satisfazer os anseios das partes interessadas e introduzir a sustentabilidade em seus contextos. No cenário científico não identificouse estudos que abordassem a relação existente entre normas de sistemas de gestão e a sustentabilidade empresarial. Sendo assim, esse estudo teve como objetivo analisar a relação entre normas de sistemas de gestão (ISO 14001, ISO 9001, OHSAS 18001 e NBR 16001) e a sustentabilidade empresarial. Para isso realizou-se uma revisão bibliográfica com o intuito de identificar os requisitos da sustentabilidade empresarial. Esses foram extraídos do Índice de Sustentabilidade Empresarial, Indicadores Ethos e Global Reporting Initiative, pois agrupam os principais elementos da sustentabilidade empresarial. Posteriormente foi construída matriz de relação contendo os requisitos da sustentabilidade empresarial e os requisitos de cada norma de sistema de gestão estudada. Essa matriz foi preenchida pela pesquisadora e por 6 especialistas que utilizam essas normas diariamente. Posteriormente as respostas foram consolidadas gerando a Matriz de Relação Consolidada (MRC) que foi analisada e interpretada. As relações foram classificadas como forte, moderada, fraca ou nula. Essa matriz foi o meio utilizado para atingir o objetivo da pesquisa. Os resultados da pesquisa apontam que a ISO 9001 e a OHSAS 18001 possuem relação fraca com a sustentabilidade empresarial. A ISO 14001 apresenta relação moderada e a NBR 16001 apresenta relação forte. Sendo assim, conclui-se que esses padrões normativos podem auxiliar as empresas a introduzirem a sustentabilidade em seu contexto, no entanto, a ISO 9001 e a OHSAS 18001 são normas que abordam apenas alguns elementos da sustentabilidade empresarial. A NBR 16001 é a norma que mais apresenta os elementos da sustentabilidade em seu escopo. Sendo assim, empresas que objetivam introduzir a sustentabilidade nos ambientes corporativos poderiam focar na implementação da NBR.

Palavras-chave: Sustentabilidade empresarial, ISO 14001, ISO 9001, OSHAS 18001, NBR 16001. 



\begin{abstract}
FERREIRA, C. S. Analysis of the relation between management system standards (ISO 9001, ISO 14001, NBR 16001 and OHSAS 18001) and corporate sustainability. 2015. 148 p. Dissertation. School of Engineering of São Carlos, University of São Paulo, São Carlos, 2015.

Sustainability is being inserted into the business context as a way to minimize the negative impacts of production processes. Organizations are ceasing to consider only economic issues and began to heed to social and environmental issues. In this context, organizations use tools such as management system standards to help stakeholders satisfy their aspirations and introduce sustainability into their contexts. A study that approached the relation between standards of management systems and corporate sustainability wasn't identified in the scientific scenery. Therefore, the goal is to analyze the relation between management system standards (ISO 14001, ISO 9001, OHSAS 18001 and NBR 16001) and corporate sustainability. A literature review was carried out in order to identify the requirements of corporate sustainability. These were taken from the Corporate Sustainability Index, Ethos Indicators and Global Reporting Initiative, for they group the main elements of corporate sustainability. Later, a relation matrix containing the requirements of corporate sustainability was built with the requirements of each standard management system studied. This matrix was filled by the researcher and six experts who use these standards daily. Later responses were consolidated generating the Consolidated Relation Matrix which was analyzed and interpreted. Relations were classified as strong, moderate, weak or null. This matrix was the means used to achieve the objective of the research. The survey results show that the ISO 9001 and OHSAS 18001 have weak relation to corporate sustainability. The ISO 14001 has moderate relation and the NBR 16001 presents strong relation. Therefore, it is concluded that these regulatory standards can help companies to introduce sustainability in their context, however, ISO 9001 and OHSAS 18001 are standards that address only some elements of corporate sustainability. The NBR 16001 is the standard that has more elements of sustainability in its scope. Thus, companies aiming to introduce sustainability into corporate environments could focus on the implementation of the NBR 16001.
\end{abstract}

Keywords: Corporate sustainability, ISO 14001, ISO 9001, OHSAS 18001, NBR 16001. 



\section{LISTA DE ABREVIATURAS E SIGLAS}

ABNT - Associação Brasileira de Normas Técnicas.

APP - Área de Preservação Permanente.

BSI - British Standards Institution.

CBT - Confederação Brasileira do Trabalho.

CERE - Coalition for Environmentally Responsible Economies.

CIPA - Comissão Interna de Prevenção de Acidente.

CLT - Consolidação das Leis de Trabalho.

CMMAD/WCED - Comissão Mundial sobre o Meio Ambiente e o Desenvolvimento.

DBO - Demanda Bioquímica de Oxigênio.

EOQC - Organização Europeia de Controle da Qualidade.

GRI - Global Reporting Initiative.

GSCM - Green Supply Chain Management.

ISE - Índice de Sustentabilidade Empresarial.

ISO - International Organization for Standardization.

MIT - Instituto de Tecnologia de Massachusetts.

NBR - Norma Brasileira.

OHSAS - Occupational Health and Safety Assessment Series.

OIT - Organização Internacional do Trabalho.

ONU - Organização das Nações Unidas.

PDCA - Plan - Do-Check - Act.

PNUMA - Programa das Nações Unidas para o Meio Ambiente.

RL - Reserva Legal.

SGA - Sistema de Gestão Ambiental.

SGQ - Sistema de Gestão da Qualidade.

SGSST - Sistema de Gestão da Saúde e Segurança do Trabalho.

SST - Segurança e Saúde do Trabalho.

TC - Comitê Técnico. 



\section{LISTA DE FIGURAS}

Figura 1 - Etapas para a realização da pesquisa.......................................................27

Figura 2 - Panorama mundial de certificações ISO 9001...........................................36

Figura 3 - Evolução temporal do número de certificações ISO 9001 no

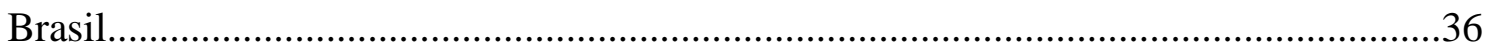

Figura 4 - Evolução temporal do número de certificações ISO 14001 no Brasil...........47

Figura 5 - Número de certificados ISO 14001 - panorama mundial...........................47

Figura 6 - Etapas de desenvolvimento da Matriz de Relacionamento..........................81 



\section{LISTA DE QUADROS}

Quadro 1 - Recorte da Matriz de Relação .29

Quadro 2 - Entradas e saídas das etapas da pesquisa.....................................................30

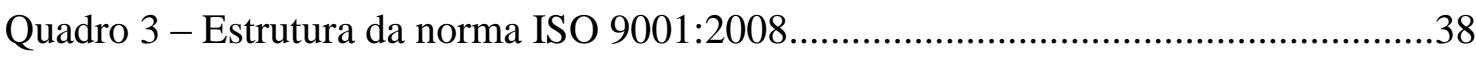

Quadro 4 - Estrutura da norma ISO 14001: 2004.....................................................49

Quadro 5 - Estrutura da norma NBR 16001:2012 _..................................................59

Quadro 6 - Estrutura da norma OHSAS 18001:2007..............................................68

Quadro 7 - Recorte da Matriz de Relação Teórica..........................................................84

Quadro 8 - Informações referentes à experiência dos especialistas...............................86

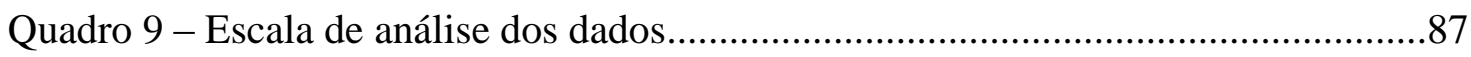

Quadro 10 - Recorte da Matriz de Relação Consolidada..................................................88

Quadro 11 - Visão geral das relações existentes entre as normas de sistema de gestão e os requisitos da sustentabilidade corporativa considerando as médias globais...... . .91

Quadro 12 - Relacionamento entre a ISO 9001 e os requisitos da sustentabilidade empresarial .93

Quadro 13 - Relacionamento entre a ISO 14001 e os requisitos da sustentabilidade empresarial. .97

Quadro 14 - Relacionamento entre a NBR 16001 e os requisitos da sustentabilidade empresarial. 100

Quadro 15 - Relacionamento entre a OHSAS 18001 e os requisitos da sustentabilidade empresarial. 104 



\begin{abstract}
APÊNDICES
Apêndice 1 - Requisitos da sustentabilidade empresarial . .122

Apêndice 2 - Termo de abertura da pesquisa.

Apêndice 3 - Matriz de Relação Consolidada ISO 9001 - Dimensão Social.

Apêndice 4 - Matriz de Relação Consolidada ISO 9001 - Dimensão Ambiental........128

Apêndice 5 - Matriz de Relação Consolidada ISO 9001 - Dimensão Econômica.......129

Apêndice 6 - Matriz de Relação Consolidada ISO 9001 - Dimensão

Socioambiental. .130
\end{abstract}

Apêndice 7 - Matriz de Relação Consolidada ISO 9001 - Dimensão Socioeconômica .131

Apêndice 8 - Matriz de Relação Consolidada ISO 9001 - Dimensão Econômico ambiental. 132

Apêndice 9 - Matriz de Relação Consolidada ISO 9001 - Dimensão ambiental - social - econômica

Apêndice 10 - Matriz de Relação Consolidada ISO 14001 - Dimensão Social. 134

Apêndice 11 - Matriz de Relação Consolidada ISO 14001 - Dimensão Ambiental...135 Apêndice 12 - Matriz de Relação Consolidada ISO 14001 - Dimensão Econômica...136 Apêndice 13 - Matriz de Relação Consolidada ISO 14001 - Dimensão socioambiental. 137

Apêndice 14 - Matriz de Relação Consolidada ISO 14001 - Dimensão socioeconômica.. 138

Apêndice 15 - Matriz de Relação Consolidada ISO 14001 - Dimensão Econômicoambiental. 
Apêndice 16 - Matriz de Relação Consolidada ISO 14001 - Dimensão ambientalsocial-econômica. 140

Apêndice 17 - Matriz de Relação Consolidada NBR 16001 - Dimensão Social. .141 Apêndice 18 - Matriz de Relação Consolidada NBR 16001 - Dimensão ambiental..142 Apêndice 19 - Matriz de Relação Consolidada NBR 16001 - Dimensão econômica..143 Apêndice 20 - Matriz de Relação Consolidada NBR 16001 - Dimensão socioambiental. 144

Apêndice 21 - Matriz de Relação Consolidada NBR 16001 - Dimensão socioeconômica.

Apêndice 22 - Matriz de Relação Consolidada NBR 16001 - Dimensão econômica ambiental. 146

Apêndice 23 - Matriz de Relação Consolidada NBR 16001 - Dimensão ambiental social- econômica. 147

Apêndice 24 - Matriz de Relação Consolidada OHSAS 18001 - Dimensão social.....148 Apêndice 25 - Matriz de Relação Consolidada OHSAS 18001 - Dimensão ambiental. 149

Apêndice 26 - Matriz de Relação Consolidada OHSAS 18001 - Dimensão econômica 150

Apêndice 27 - Matriz de Relação Consolidada OHSAS 18001 - Dimensão socioambiental. 151

Apêndice 28 - Matriz de Relação Consolidada OHSAS 18001 - Dimensão socioeconômica. 152

Apêndice 29 - Matriz de Relação Consolidada OHSAS 18001 - Dimensão econômica ambiental 153

Apêndice 30 - Matriz de Relação Consolidada OHSAS 18001 - Dimensão ambiental social - econômica. 


\section{SUMÁRIO}

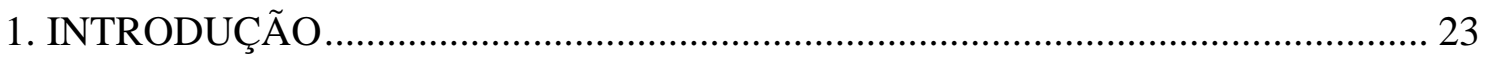

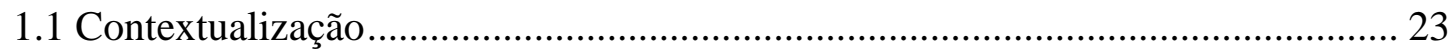

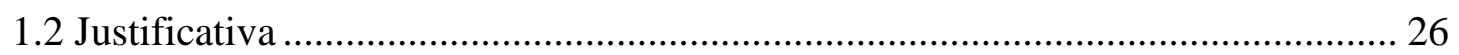

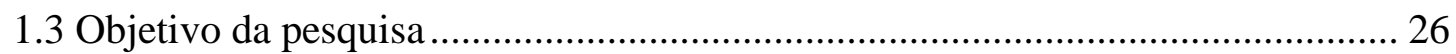

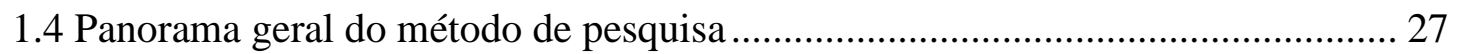

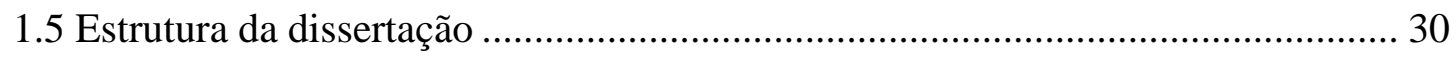

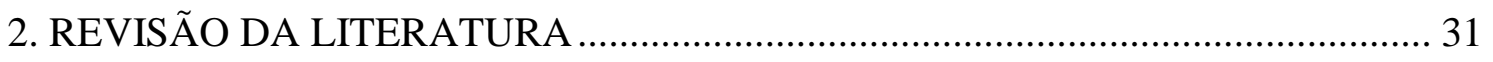

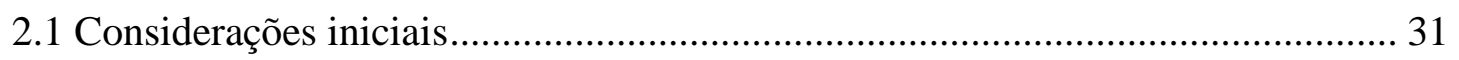

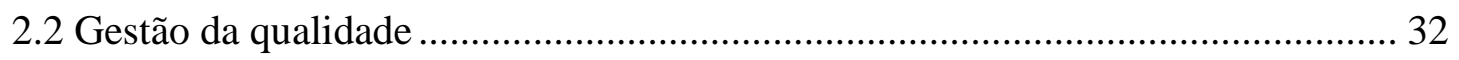

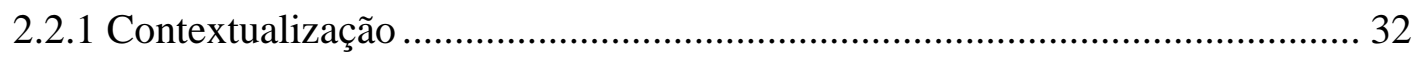

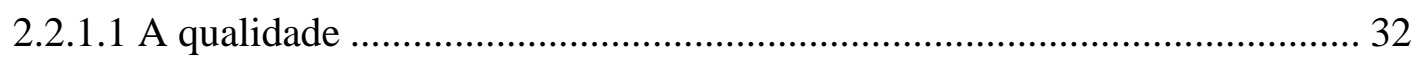

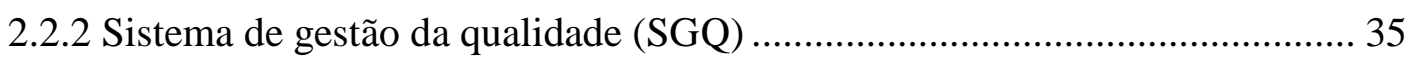

2.3 Relação homem e meio ambiente ……........................................................... 41

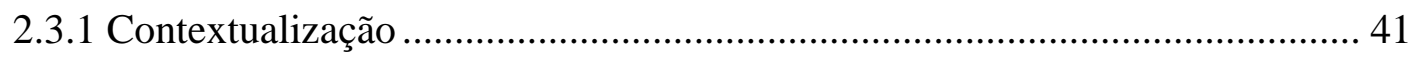

2.3.2 Gestão Ambiental Empresarial............................................................... 44

2.3.3 Sistema de Gestão Ambiental (SGA) _............................................................ 45

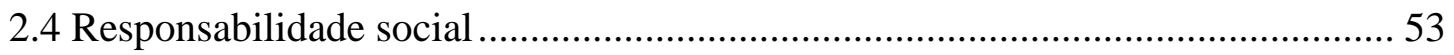

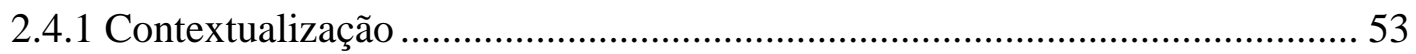

2.4.2 Responsabilidade social empresarial ..................................................... 54

2.4.3 Sistema de Gestão da Responsabilidade Social (SGRS) - ABNT ISO

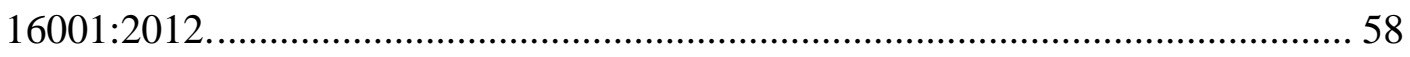

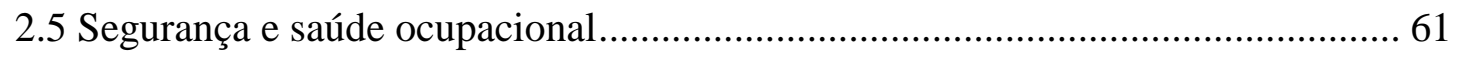

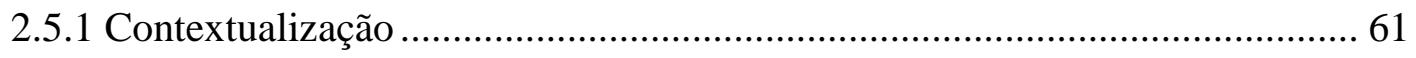

2.5.2 Sistema de gestão de segurança e saúde ocupacional - OHSAS 18001: 2007 


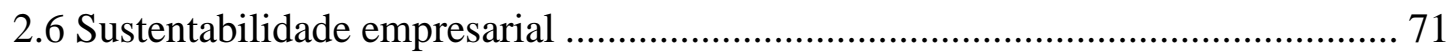

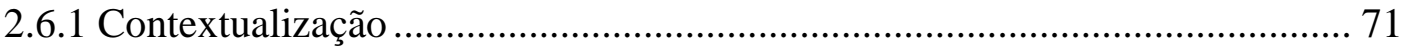

2.6.2 As dimensões/pilares da sustentabilidade ............................................... 75

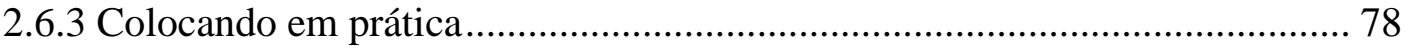

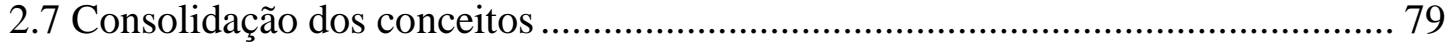

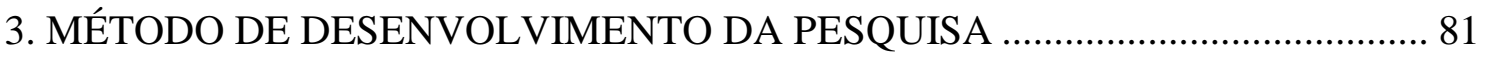

3.1 Etapa 1 - Seleção das normas de sistema de gestão ...................................... 81

3.2 Etapa 2 - Identificação dos requisitos da sustentabilidade empresarial............ 82

3.3 Etapa 3 - Preenchimento da Matriz de Relação Teórica ................................. 83

Quadro 7. Recorte da Matriz de Relação Teórica (Elaborado pela autora). ........... 84

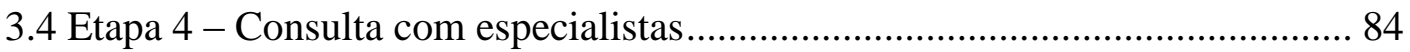

3.5 Etapa 5 - Análise dos dados e construção da Matriz de Relação Consolidada 87

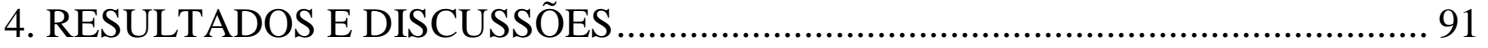

4.1 ABNT NBR ISO 9001:2008 - Sistema de gestão da qualidade - Requisitos...... 92

4.2 ABNT NBR ISO 14001:2004 - Sistema de gestão ambiental: Requisitos com

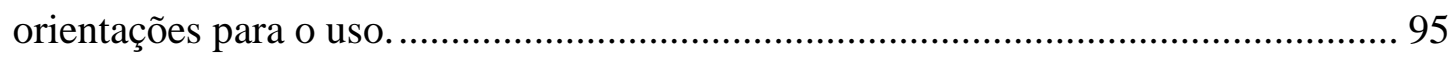

4.3 ABNT NBR 16001:2012 - Responsabilidade social - Sistema de gestão -

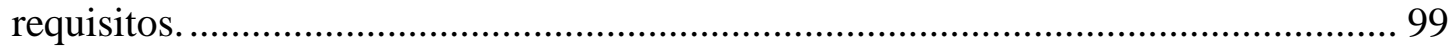

4.4 OHSAS 18001:2007 - Sistema de gestão da segurança e saúde do trabalho -

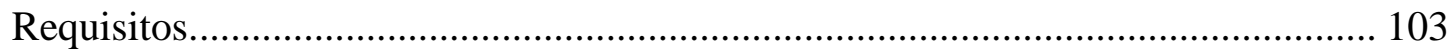

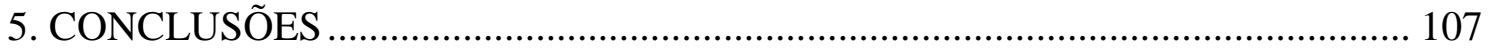

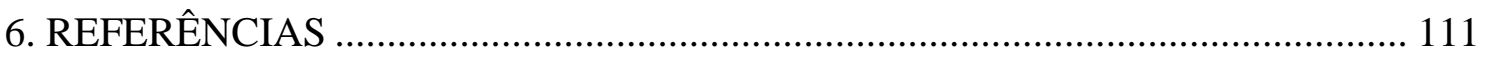

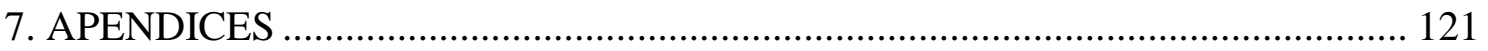




\section{Gapíuto 1}

\section{INTRODUÇÃO}

\subsection{Contextualização}

Os problemas ambientais provocados pelas ações antrópicas decorrentes do uso e exploração dos recursos naturais para produção de bens e serviços em grande escala e incentivos exagerados ao consumismo provocam a degradação do meio ambiente e ameaçam a capacidade de suporte do planeta (BARBIERI, 2011). Diante desse contexto, o desenvolvimento sustentável vem sendo proposto pelos governantes e líderes corporativos como uma alternativa de resolução de problemas ambientais, sociais e econômicos que envolve desde questões globais (ex. mudanças climáticas) até problemas regionais pontuais (ex. acesso ao saneamento básico) (ELKINGTON, 2001).

Para Elkington (2001) sustentabilidade é "o princípio de assegurar que nossas ações de hoje não limitarão a gama de opções econômicas, sociais e ambientais disponíveis para as gerações futuras". No contexto empresarial, a sustentabilidade é considerada como "a adoção de estratégias de negócios e atividades que atendam as necessidades da empresa e seus stakeholders, protegendo, mantendo e melhorando os recursos naturais que serão necessários no futuro" (INTERNATIONAL INSTITUTE FOR SUSTAINABLE DEVELOPMENT, 1992).

Com o processo de industrialização acelerado nos anos 60 os empresários acreditavam que os danos ambientais deveriam ser assumidos pela sociedade em favor do desenvolvimento econômico, onde a poluição provocada pelas organizações era lançada o mais longe possível da fonte poluidora (BARBIERI, 2011). A partir dos anos 70 se observou a busca de uma nova relação entre o meio ambiente e o desenvolvimento econômico, por meio de ações governamentais de caráter corretivo e de baixa eficiência. A poluição gerada pelas indústrias era controlada e remediada no final dos processos "end of the pipe" (fim de tubo) e o cumprimento da legislação ocorria apenas quando obrigatório (BARBIERI, 2011).

Em 1992 ocorreu no Brasil a Conferência Rio 92 realizada pelas Nações Unidas que teve como objetivos incluir as questões ambientais no centro das políticas econômicas e na tomada de decisão dos 178 países que compareceram no encontro (NAÇÕES UNIDAS, 2012; STRONG, 1991). Desde então teve início à abordagem 
estratégica da prevenção a poluição que apresenta uma visão proativa na qual a empresa busca atuar sobre os produtos e processos a fim de prevenir a geração da poluição, empreendendo ações com vistas a uma produção mais eficiente e, portanto, poupadora de materiais e energia em diferentes fases do processo de produção e comercialização (BARBIERI, 2011).

Diante desse contexto, influenciada pelas crescentes discussões relacionadas ao Meio Ambiente em 1993 a International Organization for Standardization (ISO) criou um Comitê técnico ISO/TC 207 para elaborar a série ISO 14000 que tem como objetivo prover as organizações elementos que compõe o sistema da gestão ambiental (SGA) (CERQUEIRA, 2012). As organizações de diversos segmentos estão cada vez mais interessadas em implementar o Sistema de Gestão Ambiental baseado na ISO 14001 Sistema de Gestão Ambiental - para demonstrar seu desempenho ambiental, por meio do controle dos aspectos ambientais e controle dos possíveis impactos que suas atividades possam trazer para o meio ambiente (ASSOCIAÇÃO BRASILIERA DE NORMAS TÉCNICAS, 2004).

A ISO 14001 é o padrão normativo mais utilizado por organizações que desejam implementar e certificar um sistema de gestão ambiental. Além disso, a ISO 14001 possui uma ampla divulgação mundial e compatibilidade com demais normas (BANSAL; BOGNER, 2002). De acordo com a International Organization for Standardization (2014) no final de 2013 o total de certificados ISO 14001 emitidos foi de 301.647 no mundo. No final do ano de 2012 o número total era de 284.654 certificados ISO 14001 distribuídos pelo mundo. Sendo assim, observa-se um aumento de 16.993 novos certificados.

Anteriormente ao lançamento da ISO 14001 a International Organization for Standardization lançou a ISO 9001 - Sistema de Gestão da Qualidade - em 1987 para padronização dos sistemas de gestão da qualidade (ASSOCIAÇÃO BRASILIERA DE NORMAS TÉCNICAS, 2008a). Esse padrão é o mais aceito mundialmente, sua adoção pode ser considerada uma decisão estratégica utilizada por empresas que operam em ambientes complexos, exigentes e competitivos (ASSOCIAÇÃO BRASILIERA DE NORMAS TÉCNICAS, 2010a). De acordo com a International Organization for Standardization (2014) no final de 2013 o total de certificados ISO 9001 emitidos foi de 1.129.446 no mundo. No final do ano de 2012 o número total era de 1.096.987 certificados ISO 9001 distribuídos pelo mundo. Sendo assim, observa-se um aumento de 32.459 novos certificados. 
Diante desse contexto, a gestão da qualidade auxilia as empresas a alcançarem o sucesso sustentado através do atendimento às expectativas das partes interessadas, consciência do ambiente organizacional, aprendizado e introdução de melhorias e/ou inovação (ASSOCIAÇÃO BRASILIERA DE NORMAS TÉCNICAS, 2010a). Os benefícios associados a adoção de um SGQ baseados na ISO 9001 são: maior lucratividade, maiores receitas, melhor desempenho orçamentário, redução de custos, melhor fluxo de caixa, maior retorno sobre o investimento, melhor competitividade, maior retenção e lealdade dos clientes, maior eficácia na tomada de decisão, uso otimizado dos recursos disponíveis, aumento da responsabilidade dos empregados, desenvolvimento do capital intelectual, processos otimizados, efetivos e eficientes, melhor desempenho na cadeia de suprimento, menor tempo de lançamento de produtos e melhor desempenho organizacional (ASSOCIAÇÃO BRASILIERA DE NORMAS TÉCNICAS, 2008b).

Em 1999 foi lançada a primeira versão da norma OHSAS 18001 - Sistema de Gestão da Saúde e Segurança Ocupacional - que tem como objetivo estabelecer diretrizes para implementação do sistema de gestão da Segurança e Saúde do Trabalho (SST) auxiliando as organizações a eliminarem ou minimizarem os riscos associados a segurança e saúde ocupacional de seus colaboradores (BRITISH STANDARDS INSTITUTION, 2007). No Brasil, de acordo com o Anuário Brasileiro de Proteção de 2014, até o final de dezembro de 2013 cerca de 834 empresas obtiveram o certificado OHSAS 18001 (REVISTA PROTEÇÃO, 2014).

Em 2004 foi lançada a norma NBR ISO 16001 - Sistema de Gestão da Responsabilidade social. A NBR ISO 16001 é uma norma brasileira de passível certificação criada pela Associação Brasileira de Normas Técnicas em conjunto com partes interessadas como governo, setor produtivo, organizações não governamentais, entidades de classe e academia que teve sua primeira revisão em 2012. Esta norma pretende auxiliar as organizações a contribuírem para o desenvolvimento sustentável (ASSOCIAÇÃO BRASILEIRA DE NORMAS TÉCNICAS, 2012a). No Brasil, em Abril de 2015 havia 17 empresas certificadas (INMETRO, 2015).

Diante dessa contextualização, autores afirmam que ao considerar o triple bottom line (ambiental, social e econômico) empresas que adotarem as normas ISO 9001, ISO 14001, NBR 16001 e OHSAS 18001 estarão contribuindo diretamente com a sustentabilidade empresarial (ROCHA; SEARCY, KARAPETROVIC, 2007; TSAI; CHOU, 2009). 


\subsection{Justificativa}

A sustentabilidade é um tema que vem sendo discutido com o passar do tempo. Essa temática está sendo inserida nos ambientes empresariais como uma forma de minimizar/eliminar os impactos ambientais e socioeconômicos negativos. Diante desse contexto, a Associação Brasileira de Normas Técnicas (ABNT) divulgou em 2012 uma coletânea que indica as normas que auxiliam no suporte a sustentabilidade empresarial, onde a ISO 14001 está inserida no pilar ambiental, a ISO 9001 no pilar econômico, a NBR 16001 e NBR 18801 (sistema de gestão da segurança e saúde no trabalho) fazem parte do pilar social que nesse estudo será representada pela OSHAS 18001 (ASSOCIAÇÃO BRASILIERA DE NORMAS TÉCNICAS, 2012b).

De acordo com a revisão bibliográfica os estudos encontrados referentes a ISO 9001, ISO 14001 e OHSAS 18001 apontam os benefícios da implementação dos sistemas de gestão baseadas nesses padrões normativos, as barreiras, dificuldades de implementação, a divergência de opiniões referente a melhora do desempenho econômico, ambiental e social das organização que receberam os certificados, entre outras questões. Com relação a NBR 16001 os estudo encontrados abordam temas como elaboração de diretrizes para interpretação da norma; os desafios a serem enfrentados especialmente no processo de auditorias (internas e externas); quantificação de objetivos, metas e programas e comparação com demais padrões normativos (AA 100, AS 18001, ISO 14001 e ISO 26000).

Sendo assim, não foi identificado nenhum estudo que relacionasse essas normas de sistema de gestão com a sustentabilidade empresarial. Sendo assim, essa pesquisa buscou responder a seguinte pergunta:

Qual é a relação entre as normas de sistema de gestão (ISO 9001, ISO 14001,

OHSAS 18001 e NBR 16001) e a sustentabilidade empresarial?

O estudo partirá do pressuposto de que a ISO 14001 representa um elemento que compõe o pilar ambiental, a ISO 9001 representa um elemento que compõe o pilar econômico, a OHSAS 18001 e a NBR 16001 representam elementos que compõem o pilar social.

\subsection{Objetivo da pesquisa}

Este trabalho tem como objetivo analisar as relações existentes entre as normas de sistema de gestão (ISO 14001, ISO 9001, NBR 16001, OHSAS 18001) e a sustentabilidade empresarial. 


\subsection{Panorama geral do método de pesquisa}

Para desenvolvimento dessa pesquisa, a mesma se divide em quatro macro etapas (Figura 1). Inicialmente realizou-se a revisão bibliográfica, em seguida a Matriz de Relação Teórica foi construída, posteriormente ocorreu a consulta com os especialistas e por último os dados foram compilados gerando a Matriz de Relação Consolidada.

\section{Etapas para a realização da pesquisa}

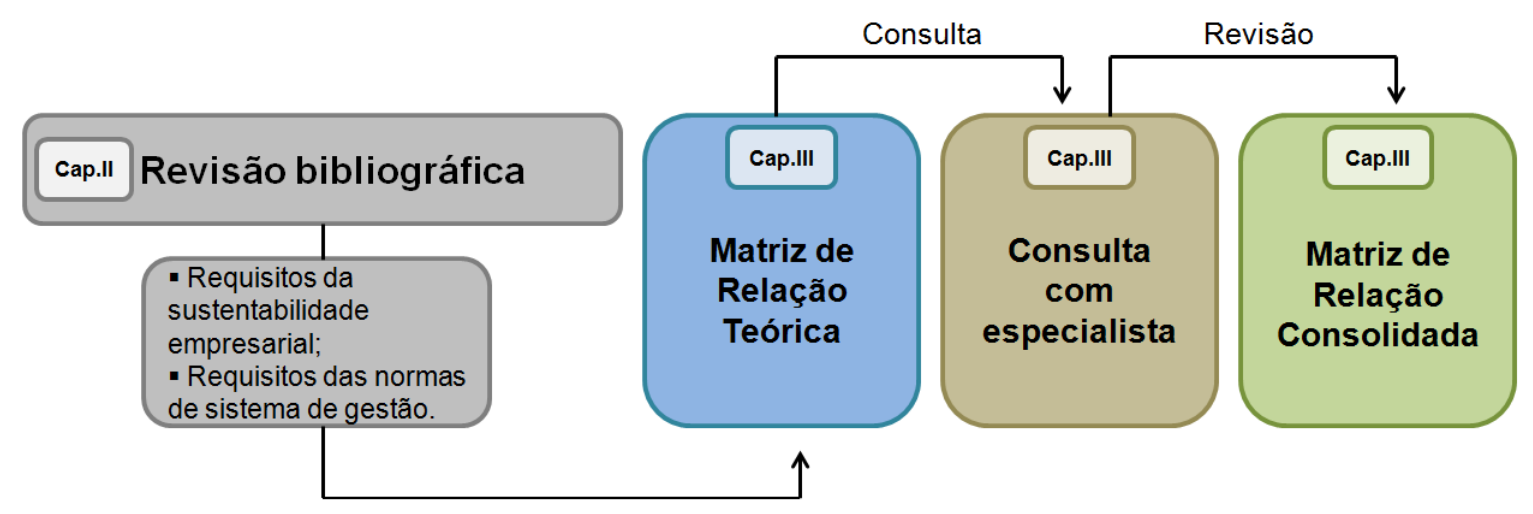

Figura 1. Etapas para a realização da pesquisa (Elaborado pela autora).

\section{Etapa 1 - Revisão bibliográfica}

Nessa etapa foi realizada a revisão bibliográfica tradicional para identificação do cenário em que a temática está inserida. Esta etapa auxiliou na definição da lacuna, problema de pesquisa, definição dos objetivos e formulação dos pressupostos.

Após a definição dos objetivos e da metodologia o próximo passo foi definir quais normas seriam utilizadas. As normas ISO 14001, ISO 9001 e OHSAS foram escolhidas pelo fato de serem mundialmente disseminadas e a NBR 16001 por ser passível de certificação. Além disso, a NBR 16001 assemelha-se em alguns aspectos com a norma ISO 26000 que é um padrão normativo que estabelece diretrizes para implementação de sistema de responsabilidade social e reconhecida mundialmente. Os aspectos semelhantes são: os princípios da transparência, comportamento ético, respeito pelas partes interessadas, respeito pelas normas internacionais de comportamento e respeito pelos direitos humanos, além do propósito do Due diligence. Todas as normas escolhidas são passíveis de certificação.

Posteriormente foi realizado uma revisão bibliográfica para contextualizar o surgimento das normas de sistema de gestão (ISO 9001, ISO 14001, OHSAS 18001 e 
NBR 16001) e identificar as principais discussões acadêmicas relacionadas com essas temáticas. Para isso foram utilizados artigos, livros, normas, teses, dissertações, documentos e dados encontrados em websites. A maioria dos artigos utilizados foram localizados nas bases de dados Web of Science e Scopus. As strings de buscas foram amplas para cada temática sendo elas: "ISO 14001”, “ISO 9001”, "NBR 16001”, "OHSAS 18001" e "corporate sustainability". Como a busca foi ampla os critérios de seleção dos artigos foram selecionar os estudos mais citados e os recentes.

O próximo passo foi realizar a revisão bibliográfica com o intuito de identificar os requisitos da sustentabilidade empresarial. Os requisitos foram identificados baseandose nos Indicadores Ethos, Índice de Sustentabilidade Empresarial e o GRI que apontam indicadores essenciais que podem ser utilizados por empresas que desejam alcançar um maior nível de maturidade referente a sustentabilidade.

Os documentos foram lidos, analisados e comparados entre si. Posteriormente, os tópicos semelhantes identificados nos documentos foram listados e transformados em requisitos. Os requisitos da sustentabilidade baseado nesses indicadores podem ser consultados no Apêndice 1.

Para finalizar essa etapa os requisitos das normas de sistema de gestão (ISO 9001, ISO 14001, OHSAS 18001 e OHSAS 18001) foram lidos, interpretados e listados.

Esta etapa foi fundamental para a construção da Matriz de Relação Teórica, pois nessa fase se identificou os requisitos da sustentabilidade considerando as dimensões do triple bottom line (ambiental, econômico, social e suas inter-relações).

\section{Etapa 2 - Construção da Matriz de Relação Teórica}

Esta etapa teve como objetivo elaborar um instrumento que pudesse ser utilizada para identificar o relacionamento entre a sustentabilidade empresarial e as normas de sistemas de gestão. A Matriz de Relação Teórica foi construída através da inserção dos requisitos da sustentabilidade empresarial (nas linhas) e dos requisitos das normas de sistemas de gestão (ISO 9001, ISO 14001, NBR 16001 e OHSAS 18001) identificados na etapa anterior.

\section{Etapa 3 - Construção da Matriz de Relação Consolidada}

A construção da Matriz de Relação Consolidada teve como objetivo identificar a relação existente entre os requisitos da sustentabilidade empresarial e os requisitos das 
normas de sistema de gestão. A Matriz de Relação Teórica é a Matriz de Relação Consolidada não preenchida.

Para alcançar esse objetivo a Matriz de Relação Teórica foi preenchida pela pesquisadora considerando a escala definida pelo método Desdobramento da Função Qualidade onde $0=$ sem relação, $3=$ relação fraca e $9=$ relação forte (CARPINETTI, 2012).

Posteriormente, para garantir maior confiabilidade nas relações optou-se por consultar especialistas nas normas de sistemas de gestão estudadas. A Matriz de Relação Teórica foi encaminhada para especialistas em normas de sistema de gestão ISO 9001, ISO 14001, OHSAS 18001 e NBR 16001 que preencheram a matriz. Em seguida, as repostas dos especialistas e da pesquisadora foram compiladas gerando a Matriz de Relação Consolidada (Apêndices 3, 4, 5, 6, 7, 8 e 9), onde as análises foram baseadas nas médias das respostas dos especialistas.

O quadro 1 apresenta um recorte da Matriz de Relação Consolidada.

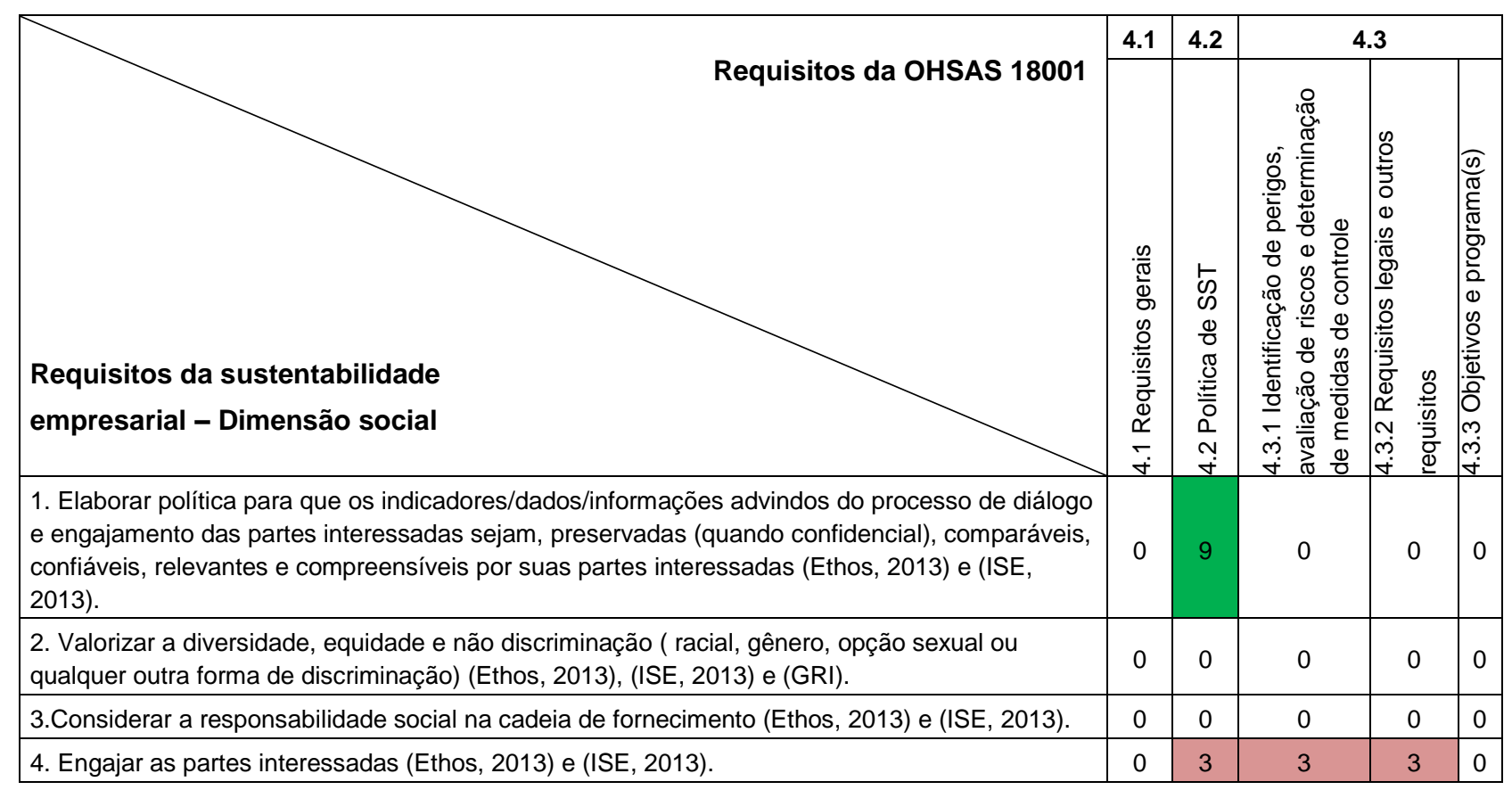

Quadro 1. Recorte da Matriz de Relação (Elaborado pela autora).

Diante desse contexto, o quadro 2 apresenta as entradas e saídas das etapas metodológicas que envolvem a realização da pesquisa. 


\begin{tabular}{|c|c|c|c|}
\hline Etapas metodológicas & Entradas & Processos & Saídas \\
\hline \multirow{3}{*}{$\begin{array}{c}\text { i) Realizar revisão } \\
\text { bibliográfica exploratória } \\
\text { sobre sustentabilidade } \\
\text { empresarial e as normas } \\
\text { de sistemas de gestão } \\
\text { (ISO 14001, ISO } 9001 \text {, } \\
\text { NBR 16001, OHSAS } \\
\text { 18001). }\end{array}$} & $\begin{array}{l}\text { 1. Artigos, livros, teses, } \\
\text { dissertações, entre outros } \\
\text { documentos. }\end{array}$ & $\begin{array}{l}\text { 1. Fazer a revisão } \\
\text { bibliográfica } \\
\text { tradicional/exploratória. }\end{array}$ & $\begin{array}{l}\text { 1. Definição da lacuna } \\
\text { de pesquisa, dos } \\
\text { objetivos e } \\
\text { pressupostos. }\end{array}$ \\
\hline & $\begin{array}{l}\text { 2. Artigos, livros, teses, } \\
\text { dissertações, entre outros } \\
\text { documentos. }\end{array}$ & $\begin{array}{l}\text { 2. Fazer a revisão } \\
\text { bibliográfica } \\
\text { tradicional/exploratória. }\end{array}$ & $\begin{array}{l}\text { 2. Definição das } \\
\text { normas de sistema de } \\
\text { gestão que serão } \\
\text { utilizadas (ISO 9001, } \\
\text { ISO 14001, OHSAS } \\
18001 \text { e NBR 16001). }\end{array}$ \\
\hline & $\begin{array}{l}\text { 3. Artigos, livros, teses, } \\
\text { dissertações, entre outros } \\
\text { documentos. }\end{array}$ & $\begin{array}{l}\text { 3. Fazer a revisão } \\
\text { bibliográfica } \\
\text { tradicional/exploratória. }\end{array}$ & $\begin{array}{l}\text { 3. Revisão } \\
\text { bibliográfica das } \\
\text { normas de sistema de } \\
\text { gestão. }\end{array}$ \\
\hline $\begin{array}{l}\text { ii) Interpretar e identificar } \\
\text { os requisitos das normas } \\
\text { de sistemas de gestão. }\end{array}$ & $\begin{array}{l}\text { 4. Normas de sistema de } \\
\text { gestão. }\end{array}$ & $\begin{array}{l}\text { 4. Interpretar e analisar as } \\
\text { normas de sistemas de } \\
\text { gestão. }\end{array}$ & $\begin{array}{l}\text { 4. Levantamento dos } \\
\text { requistos das normas } \\
\text { de sistemas de } \\
\text { gestão. }\end{array}$ \\
\hline $\begin{array}{l}\text { iii) Identificar os requisitos } \\
\text { da sustentabilidade } \\
\text { empresarial. }\end{array}$ & $\begin{array}{l}\text { 5. Indicadores Ethos, Índice } \\
\text { de Sustentabilidade } \\
\text { Empresarial e GRI. }\end{array}$ & $\begin{array}{l}\text { 5. Identificar os requisitos } \\
\text { da sustentabilidade } \\
\text { empresarial. }\end{array}$ & $\begin{array}{l}\text { 5. Requisitos da } \\
\text { sustentabilidade } \\
\text { empresarial. }\end{array}$ \\
\hline \multirow{3}{*}{$\begin{array}{l}\text { iv) Construir a Matriz de } \\
\text { Relação Teórica. }\end{array}$} & $\begin{array}{l}\text { 5. Requisitos da } \\
\text { sustentabilidade } \\
\text { empresarial. }\end{array}$ & $\begin{array}{l}\text { 5. Inserir na Matriz de } \\
\text { Relação Teórica. }\end{array}$ & $\begin{array}{l}\text { 5. Matriz de Relação } \\
\text { Teórica. }\end{array}$ \\
\hline & $\begin{array}{l}\text { 6. Requisitos das normas } \\
\text { de sistema de gestão. }\end{array}$ & $\begin{array}{l}\text { 6. Inserir na Matriz de } \\
\text { Relação Teórica. }\end{array}$ & $\begin{array}{l}\text { 6. Matriz de Relação } \\
\text { Teórica. }\end{array}$ \\
\hline & $\begin{array}{l}\text { 7. Matriz de Relação } \\
\text { Teórica. }\end{array}$ & $\begin{array}{l}\text { 7. Fazer as relações de } \\
\text { acordo com a escala } \\
\text { determinada. }\end{array}$ & $\begin{array}{l}\text { 7. Matriz de Relação } \\
\text { Teórica. }\end{array}$ \\
\hline $\begin{array}{l}\text { V) Consolidar a Matriz de } \\
\text { Relação Teórica através } \\
\text { da consulta com } \\
\text { (profissionais que } \\
\text { trabalham diretamente } \\
\text { com os sistemas de } \\
\text { gestão). }\end{array}$ & $\begin{array}{l}\text { 8. Matriz de Relação } \\
\text { Teórica. }\end{array}$ & 8. Consultar especialistas. & $\begin{array}{l}\text { 8. Matriz de Relação } \\
\text { Teórica. }\end{array}$ \\
\hline $\begin{array}{l}\text { vi) Compilar as opiniões } \\
\text { dos especialistas e gerar } \\
\text { a Matriz de Relação } \\
\text { Consolidada. }\end{array}$ & $\begin{array}{l}\text { 9. Matrizes de relações } \\
\text { teóricas preenchidas pelos } \\
\text { especialistas (incluindo a } \\
\text { pesquisadora). }\end{array}$ & 9. Compilação dos dados. & $\begin{array}{l}\text { 9. Matriz de Relação } \\
\text { Consolidada }\end{array}$ \\
\hline $\begin{array}{l}\text { vii) Analisar a Matriz de } \\
\text { Relação Consolidada e } \\
\text { concluir o estudo. }\end{array}$ & $\begin{array}{l}\text { 10. Matriz de Relação } \\
\text { Consolidada }\end{array}$ & 10. Analise dos dados. & $\begin{array}{l}\text { 10. Conclusão do } \\
\text { estudo. }\end{array}$ \\
\hline
\end{tabular}

Quadro 2. Entradas e saídas das etapas da pesquisa (Elaborado pela autora).

\subsection{Estrutura da dissertação}

A dissertação está dividido em 5 capítulos que são:

O capítulo 1 apresenta a contextualização, justificativa, contribuição da pesquisa, questão de pesquisa, apresentação das etapas da pesquisa e o método que foi utilizado.

O capítulo 2 apresenta a revisão bibliográfica.

O capítulo 3 apresenta o método da pesquisa.

O capítulo 4 apresenta os resultados e discussões.

O capítulo 5 apresenta a conclusão e contribuições da pesquisa. 


\section{Capíula 2}

\section{REVISÃO DA LITERATURA}

Este capítulo tem como intuito a construção de um quadro teórico que permita a compreensão das temáticas abordadas nessa pesquisa, através de uma revisão da literatura a respeito dos seguintes assuntos: sistemas de gestão (qualidade, ambiental, social e segurança e saúde ocupacional) e sustentabilidade empresarial.

\subsection{Considerações iniciais}

Esse capítulo apresentará a evolução histórica da qualidade até a elaboração da norma ISO 9001, além disso, apontará barreiras, vantagens, desvantagens, entre outras questões relacionadas a implementação dessa norma.

Em seguida apontará os primeiros marcos e eventos internacionais que discutiram a temática sustentabilidade, os diferentes sistemas de gestão ambiental e finalmente a criação da ISO 14001.

A próxima sessão apresenta uma breve contextualização referente a temática responsabilidade social em especial aos direitos humanos universal, posteriormente a inserção da responsabilidade social nas empresas e por último apresenta a NBR ISO 16001 que nesse estudo representa o pilar social.

Posteriormente esse capítulo apresentará uma revisão bibliográfica a respeito da gestão da segurança e saúde ocupacional que discute brevemente temas relacionados a direitos trabalhistas, doenças relacionadas ao trabalho, acidentes ocupacionais e finalmente apresenta a OHSAS 18001 que nesse estudo representa apenas um dos elementos que compõe o pilar social.

Diante desse contexto, acredita-se importante entender o background do surgimento da ISO 9001, ISO 14001, NBR 16001 e OHSAS 18001 para compreender a criação dessas normas.

A penúltima sessão desse tópico apresentará uma discussão referente a sustentabilidade empresarial que inclui conceitos, as dimensões e pilares da sustentabilidade, o Índice de Sustentabilidade Empresarial, os Indicadores Ethos e o Global Reporting Initiative. A última sessão aponta as considerações gerais do estudo. 


\subsection{Gestão da qualidade}

\subsubsection{Contextualização}

Uma breve contextualização será apresentada para compreender os principais tópicos relacionados a ISO 9001 para que posteriormente seja possível correlacionar os requisitos desse padrão normativo com a sustentabilidade corporativa.

\subsubsection{A qualidade}

O termo qualidade atualmente tornou-se de domínio comum e uso público devido aos esforços realizados no passado para popularização desse conceito, no entanto, em alguns casos as definições divulgadas são incorretas conduzindo tomadas de decisões errôneas (PALADINI, 2004).

Segundo a Organização Europeia de Controle da Qualidade (EOQC) "qualidade é a condição necessária de aptidão para o fim a que se destina" (EOQC, 1972 apud PALADINI, 2004). A ISO define qualidade como "grau no qual um conjunto de características inerentes satisfaz a requisitos (necessidade ou expectativa que é expressa, geralmente de forma implícita ou obrigatória)" (ASSOCIAÇÃO BRASILEIRA DE NORMAS TÉCNICAS, 2005).

Para Crosby (1994) qualidade é "induzir as pessoas a fazer melhor tudo aquilo que devem fazer" onde as "pessoas" incluem todas os colaboradores de uma organização considerando desde a Alta Direção até os funcionários de níveis hierárquicos inferiores.

A qualidade pode ser apresentada em cinco abordagens que foram descritas por Garvin (1992). Na abordagem transcendente a qualidade é sinônimo de "qualidade inata" e universalmente reconhecida. É uma propriedade simples, não passível de análise e reconhecida apenas pela experiência. Para o autor a qualidade "não vai além de alegações de que, qualquer que seja a natureza da qualidade, os gerentes conhecê-laão quando virem".

$\mathrm{Na}$ abordagem baseada no produto a qualidade é vista como uma variável precisa e mensurável. Considera que produtos de qualidade possuem altos custos e é vista como uma característica inerente ao produto. A abordagem baseada no usuário considera que qualidade é atender as necessidades dos consumidores, ou seja, produtos de alta qualidade são aqueles que satisfazem ao máximo os clientes. A abordagem baseada na produção considera a qualidade como "conformidade com as especificações", onde 
qualquer desvio do planejado implica na queda da qualidade. E na abordagem baseada no valor a qualidade é percebida em relação ao preço do produto (GARVIN, 1992).

Diante desse contexto, o conceito de qualidade varia de acordo com as áreas do conhecimento (filosofia, economia, marketing e gerência de operações) descritas por Garvin (1992). No entanto, observa-se que as definições giram em torno da necessidade de atendimento a especificações, satisfação dos clientes e adequação ao uso, além disso, envolve uma interação entre produto, uso e cliente.

\subsubsection{Evolução histórica - Eras da qualidade}

$\mathrm{Na}$ Idade Média os produtos eram manufaturados por artesões. Nessa época, a inspeção estava incorporada nos processos produtivos, pois existia um mestre de ofício responsável por revisar cada produto finalizado para garantir sua qualidade (PALADINI, 2004). No início do século XX Taylor observou a necessidade de fabricação de produtos intercambiáveis e padronizados para atender a produção em massa. Com o crescimento industrial houve a necessidade da criação de medidas, métricas e divisão do trabalho, sendo assim surge à figura do inspetor da qualidade que tinha a função de separar os produtos "bons" dos "ruins" (GARVIN, 1992).

$\mathrm{Na}$ década de 30 o conceito de controle estatístico da qualidade (consiste na extração do máximo de informações retiradas de um mínimo de dados de inspeção) foi introduzido pela primeira vez no cenário científico. De acordo com esse conceito, a variabilidade é inevitável na realidade industrial, sendo que essa variação pode apresentar dois componentes: um uniforme que está sempre presente por ser inerente ao processo e outro intermitente que surge durante a realização do trabalho (SHEWART, 1981).

Durante a Segunda Guerra Mundial existia uma urgência na produção de novos produtos, porém a mão de obra mal qualificada interferia na qualidade dos mesmos. Para solucionar esse problema foram criados programas formais de qualificação pessoal. Em seguida, no período conhecido como Guerra Fria o conceito de qualidade se intensificou para que os produtos bélicos sofisticados fossem fabricados de maneira confiável e não necessitassem de manutenção periódica (GARVIN, 1992).

Após a Segunda Guerra Mundial a qualidade passou de uma disciplina restrita ao processo de fabricação e incorporou-se no gerenciamento. Em 1951 Juran classificou os custos associados à produção em: custos evitáveis que estão relacionados a falhas e 
defeitos e os custos inevitáveis relacionados à prevenção (inspeção, amostragem, entre outras iniciativas de controle da qualidade) (GARVIN, 1992).

Em 1956 Feigenbaum propôs o controle da qualidade total e afirmava que a qualidade era um trabalho de todos, ou seja, todos tinham que trabalhar no projeto de um produto até a satisfação dos clientes. Posteriormente surgiu a engenharia de confiabilidade que tinha como objetivo garantir que um produto mantivesse seu desempenho em longo prazo. Em 1961 surgiu a filosofia de que o único padrão de qualidade aceitável era zero defeito (GARVIN, 1992).

No final da década de 70 os produtos japoneses de alta qualidade invadiram o mercado americano proporcionando a insatisfação dos clientes com os produtos nacionais. As pressões do governo forçaram a introdução dos conceitos da qualidade desenvolvidos pela indústria bélica nas demais corporações, já que a competição com o mercado japonês estava tornando-se desleal. Introduziu-se então o conceito de gestão estratégica da qualidade que se preocupa com a melhoria contínua para satisfação dos clientes, fornecedores, colaboradores, acionistas e a sociedade (CAMPOS, 2004).

Nos anos 80 e 90 Juran conceituou a Gestão da Qualidade Total como “o sistema de atividades dirigidas para se atingir clientes satisfeitos, empregados com responsabilidade e autoridade, maior faturamento e menor custo" (JURAN; GRYNA 1993). Diante dessa definição a gestão da qualidade total é vista como uma extensão do planejamento dos negócios objetivando aumentar a competitividade de uma empresa por meio de um conjunto de fundamentos e técnicas da gestão da qualidade valorizando a melhoria contínua (CARPINETTI, 2012).

A partir de 2000 o termo Gestão da Qualidade Total passou a ser substituído por Gestão da Qualidade (CARPINETTI, 2012). Os princípios básicos da gestão da qualidade estão relacionados com foco no cliente, liderança, envolvimento de pessoas, abordagem de processos, abordagem sistêmica para gestão, melhoria contínua, abordagem factual para a tomada de decisão e benefícios mútuos nas relações com fornecedores (ASSOCIAÇÃO BRASILEIRA DE NORMAS TÉCNICAS, 2005).

A gestão da qualidade em níveis operacionais visa satisfazer os anseios dos clientes e reduzir os custos decorrentes da não qualidade. Os custos são divididos em falhas internas que são detectados antes que o produto seja entregue ao cliente (refugo, retrabalho, reinspeção, reteste, redução do preço de vendo do produto devido à baixa qualidade, entre outros), custos de falhas externas identificadas quando o produto está disponível aos clientes (custo de assistência técnica, multas e rompimento de contratos), 
custos de avaliação da qualidade que estão associados a atividades de verificação de conformidade dos produtos (inspeção em processo e produtos obtidos de fornecedores, auditorias de qualidade, entre outras) e custos de prevenção que visa garantir a redução dos custos relacionados a falhas e avaliações (planejamento da qualidade, controle de processo, treinamentos, qualificação e desenvolvimento de fornecedores, entre outros (CARPINETTI, 2012).

Diante desse contexto, os custos da não qualidade poderão ser substituídos pelos custos da qualidade como um caminho interessante para a redução de desperdício. Essa mudança de pensamento poderá garantir a satisfação dos clientes e a manutenção dos produtos no mercado garantindo a sustentabilidade financeira das organizações.

\subsubsection{Sistema de gestão da qualidade (SGQ)}

Segundo Falconi (2009) sistema de gestão é "um conjunto de ações interligadas de tal maneira que os resultados da empresa sejam atingidos", além disso, através de um sistema de gestão é possível definir e demonstrar onde o trabalho de cada funcionário está inserido. Sendo assim, o SGQ auxilia as empresas que possuem dificuldades em atender as necessidades dos clientes e de outras partes interessadas (CERQUEIRA, 2012).

Os primeiros Sistemas da Qualidade formais e documentados tinham como objetivo selecionar os fornecedores que atendiam os requisitos especificados (CERQUEIRA, 2012). Em 1959 foi emitida nos Estados Unidos a especificação militar MIL-Q-9858A e MIL-145208A que estabelecem requisitos para a adoção de um SGQ. A partir desse momento, o Departamento de Defesa dos Estados Unidos passou a exigir que seus fornecedores documentassem seus sistemas de gestão de acordo com essas normas (MIL, 1959).

No Reino Unido a primeira norma de SGQ lançada pela British Standard foi a BS-5750. Diante dessa situação a ISO estabeleceu um Comitê Técnico TC 176 a fim de elaborar um padrão que pudesse ser utilizado pelos diversos setores indústrias e de serviços. O Comitê consolidou os conteúdos apresentados nas diversas normas existentes e elaborou as Normas para Sistemas da Qualidade - ISO série 9000 (CERQUEIRA, 2012).

Desde então muitas empresas vem adotando esses padrões para garantir um SGQ eficaz. De acordo com a International Organization for Standardization (2014) no final de 2013 o total de certificados ISO 9001 emitidos foi de 1.129 .446 no mundo. No final 
do ano de 2012 o número total era de 1.096 .987 certificados ISO 9001 distribuídos pelo mundo. Sendo assim, observa-se um aumento de 32.459 novos certificados como mostra a figura 2 .

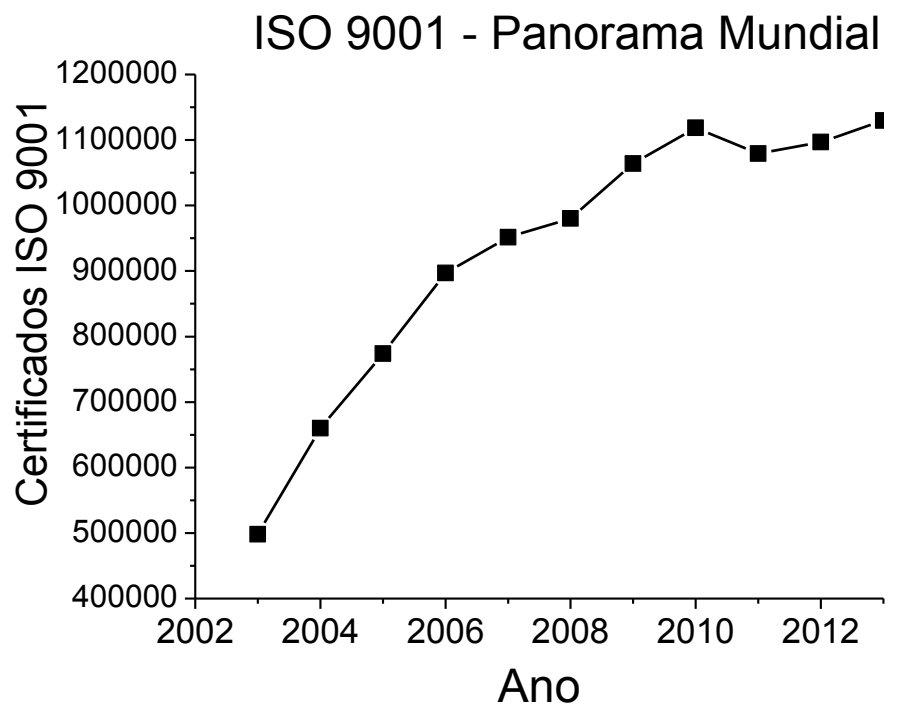

Figura 2. Panorama mundial de certificações ISO 9001 (INTERNATIONAL ORGANIZATION FOR STANDARDIZATION, 2014).

No Brasil o número de certificações ISO 9001 no ano de 2013 (22.128) foi inferior se compararmos com o ano de 2012 (25.791 certificados) como mostra a figura 3.

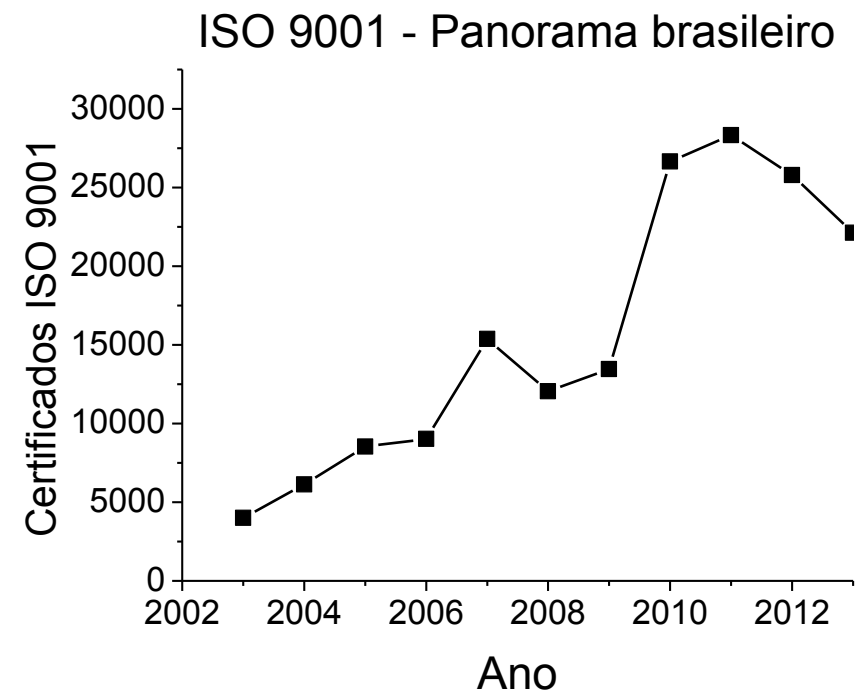

Figura 3. Evolução temporal do número de certificações ISO 9001 no Brasil (INTERNATIONAL ORGANIZATION FOR STANDARDIZATION, 2014).

Diante desse contexto, analisou-se que a norma ISO 9001:2008 é o padrão mais utilizado mundialmente para certificar SGQ (TERZIOVSKI; SAMSON; DOW, 1997). 


\subsubsection{Sistema de Gestão da Qualidade - ABNT NBR ISO 9001:2008}

A primeira versão da norma ISO 9001 foi publicada em 1987 e passou por três revisões nos anos de 1994, 2000 e 2008. Anteriormente a revisão ocorrida em 2000 os sistemas de gestão eram baseadas nas normas ISO 9001, ISO 9002 e ISO 9003. Posteriormente a ISO 9001:2000 consolidou as temáticas e passou a ter um enfoque gerencial para garantir a eficácia da organização em vários aspectos (VALLS, 2004). A norma ISO 9001:2008 estabelece requisitos de gestão da qualidade com base em um modelo de sistema de gestão (CARPINETTI, 2012).

O modelo baseia-se nos princípios de gestão da qualidade total que envolve: foco no cliente, liderança, envolvimento das pessoas, abordagem de processo, abordagem sistêmica para a gestão, melhoria contínua, tomada de decisão baseada em fatos e benefícios mútuos nas relações com os fornecedores (VITORELLI, 2011).

A metodologia utilizada pela ISO 9001:2008 para garantir a melhoria contínua do sistema de gestão da qualidade é o PDCA que significa (ASSOCIAÇÃO BRASILIERA DE NORMAS TÉCNICAS, 2008):

$\checkmark$ Plan (planejar): estabelece os objetivos e processos necessários para gerar resultados de acordo com os requisitos dos clientes e com a política da organização;

$\checkmark$ Do (fazer): implementar os processos;

$\checkmark$ Check (checar): monitorar e medir processos e produtos em relação às políticas, aos objetivos e aos requisitos para produto e relatar os resultados; e

$\checkmark$ Act (agir): executar ações para promover continuamente a melhoria do desempenho do processo.

A ISO 9001 estabelece cinco requisitos que estão inter-relacionados que são: Sistema da Qualidade; Responsabilidade da Direção; Gestão de Recursos; Realização do Produto; e Medição, Análise e Melhoria (CARPINETTI; MIGUEL; GEROLAMO, 2011) como mostra a quadro 3. 


\begin{tabular}{|c|c|c|}
\hline Cláusula & & Título do requisito \\
\hline 4.1 & & Requisitos gerais \\
\hline 4.2 & & Requisitos de documentação \\
\hline \multirow{6}{*}{5} & \multirow{6}{*}{ Responsabilidade da Direção } & 5.1 Comprometimento da direção \\
\hline & & 5.2 Foco no cliente \\
\hline & & 5.3 Política da qualidade \\
\hline & & 5.4 Planejamento \\
\hline & & 5.5 Responsabilidade, autoridade e comunicação \\
\hline & & 5.6 Análise crítica pela direção \\
\hline \multirow{3}{*}{6} & \multirow{3}{*}{ Gestão de Recursos } & 6.1 Provisão de recursos \\
\hline & & 6.2 Recursos humanos \\
\hline & & 6.4 Ambiente de trabalho \\
\hline \multirow{6}{*}{7} & \multirow{6}{*}{ Realização do Produto } & 7.1 Planejamento da realização do produto \\
\hline & & 7.2 Processos relacionados a clientes \\
\hline & & 7.3 Projeto e desenvolvimento \\
\hline & & 7.4 Aquisição \\
\hline & & 7.5 Produção e prestação de serviços \\
\hline & & 7.6 Controle de equipamento de monitoramento e medição \\
\hline \multirow{5}{*}{8} & \multirow{5}{*}{ Medição, Análise e Melhoria } & 8.1 Generalidades \\
\hline & & 8.2 Monitoramento e medição \\
\hline & & 8.3 Controle de produto não conforme \\
\hline & & 8.4 Análise de dados \\
\hline & & 8.5 Melhoria \\
\hline
\end{tabular}

Quadro 3. Estrutura da norma ISO 9001:2008 (ASSOCIAÇÃO BRASILEIRA DE NORMAS TÉCNICAS, 2008a).

\section{Requisitos gerais e de documentação}

A documentação do sistema de gestão da qualidade deve incluir a política e os objetivos da qualidade, o manual da qualidade, registros, procedimentos e outros documentos necessários para a sustentação do sistema de gestão (VITORELLI, 2011).

\section{Responsabilidade da direção}

A alta direção deverá comprometer-se a melhorar continuamente o sistema de gestão da qualidade (NETO; TAVARES; HOFFMANN, 2013). A política da qualidade deve ser uma declaração dos princípios e valores de uma organização. A alta direção deverá estabelecer objetivos que sejam mensuráveis e estejam coerentes com a política da qualidade. Os objetivos deverão ser monitorados por meio de indicadores (VITORELLI, 2011). 


\section{Gestão de recursos}

Os requisitos que compõem essa sessão estão relacionados a necessidade das organizações no processo de identificação e disponibilização de recursos necessários para garantir o funcionamento do sistema de gestão. Esses recursos incluem instalações, equipamentos, ambiente de trabalho, recursos financeiros e humanos (NETO; TAVARES; HOFFMANN, 2013). Além disso, a organização deve assegurar que todos que trabalhem em seu nome estejam conscientes a respeito da importância do sistema de gestão e estejam comprometidas com sua manutenção (CARPINETTI, 2011).

\section{Realização do produto}

Os requisitos apresentados nessa sessão estão relacionados a todas as etapas do processo de realização do produto (NETO; TAVARES; HOFFMANN, 2013). As organizações deverão planejar as atividades de produção em função dos anseios dos clientes. Temas como aquisição (os produtos e serviços adquiridos para realização de um produto podem interferir na qualidade dos mesmo, sendo assim, requisitos tais como qualidade, baixos custos e pontualidade na entrega devem ser considerados), produção e fornecimento de serviços (produtos/serviços que atendam as especificações) e controle de equipamentos de monitoramento e controle (a organização deve definir os equipamentos de medição para monitorar seus processos de forma que os erros sistemáticos e/ou aleatórios sejam compatíveis com os erros de produção) (VITORELLI, 2011).

\section{Medição, análise e melhoria}

Essa sessão trata-se da mensuração, análise e melhoria do sistema de gestão da qualidade, por meio da realização do monitoramento da satisfação do cliente, auditorias internas, controle de produtos não conformes e ações para prevenir a ocorrência de problemas (NETO; TAVARES; HOFFMANN, 2013).

A adoção do sistema de gestão da qualidade baseado nos padrões ISO 9001 é considerado uma decisão estratégica tomada pelas organizações (ASSOCIAÇÃO BRASILEIRA DE NORMAS TÉCNICAS, 2008a). Esse padrão é utilizado por empresas que estejam operando em ambientes complexos, exigentes e competitivos (ASSOCIAÇÃO BRASILEIRA DE NORMAS TÉCNICAS, 2010a). 
As indústrias aeronáuticas e automotivas foram as primeiras a adotarem o padrão ISO 9001, no entanto, rapidamente a implementação do sistema de gestão da qualidade expandiu-se para outros setores e atualmente tornou-se um requisito comum e um fator de competitividade e sobrevivência das empresas (FERREIRA-REBELO; SILVA; SANTOS, 2014).

Diante desse contexto, a gestão da qualidade auxilia as empresas a alcançarem o sucesso sustentado, através do atendimento às expectativas das partes interessadas, consciência do ambiente organizacional, aprendizado e introdução de melhorias e/ou inovação (ASSOCIAÇÃO BRASILEIRA DE NORMAS TÉCNICAS, 2010a). De acordo com a Associação Brasileira de Normas Técnicas (2008b) os benefícios econômicos associados a adoção de um SGQ são: maior lucratividade, maiores receitas, melhor desempenho orçamentário, redução de custos, melhor fluxo de caixa, maior retorno sobre o investimento, melhor competitividade, maior retenção e lealdade dos clientes, maior eficácia na tomada de decisão, uso otimizado dos recursos disponíveis, aumento da responsabilidade dos empregados, desenvolvimento do capital intelectual, processos otimizados, efetivos e eficientes, melhor desempenho na cadeia de suprimento, menor tempo de lançamento de produtos e melhor desempenho organizacional, credibilidade e sustentabilidade.

O aumento da eficiência, definição de responsabilidade, melhorias no trabalho em equipe, melhora na gestão interna, aumento da confiança dos clientes, aumento da fatia de mercado, aumento de lucros e diminuição de custos foram descritos por Zeng, Tian e Tam (2005) como sendo os principais benefícios associado a certificação pelo padrão ISO 9001.

Em uma pesquisa realizada com 300 auditores da qualidade na Nova Zelândia Terziovski, Power e Sohal (2003) encontram evidências que levaram a conclusão de que empresas que adotam o padrão ISO 9001 acreditam que obterão melhora no desempenho dos negócios se a cultura da qualidade for disseminada efetivamente nas organizações. Segundo Qi et al. (2013) a norma ISO 9001 é vista como um alicerce fundamental para o desenvolvimento econômico sustentável de uma empresa.

Em um estudo realizado na China desenvolvido por Zeng; Tian; Tam (2005) em 100 empresas de construção e engenharia civil certificadas ISO 9001 os autores identificaram que as motivações que levaram essas empresas a adotarem o padrão ISO 9001 estão associadas com a melhora na reputação da empresa, satisfazer as exigências dos clientes, responder ao apelo dos governos e melhorar a gestão da organização. 
Atualmente os estudos que envolvem a ISO 9001 estão focando em motivações para adoção da norma ISO 9001 (Allur; Heras-Saizarbitoria; Casadesus, 2014), aumento de empresas que estão perdendo seus certificados (Alič, 2014), integração desse padrão com a OHSAS 18001 (Vitoreli; Carpinetti, 2013) e com a 14001 (Simon; Karapetrovic; Casadesús, 2012).

A ISO 9001 está passando atualmente (julho/2015) pelo processo de revisão. As principais mudanças que ocorrerão estão relacionadas a maior ênfase na geração de valor e na avaliação dos riscos, considerar as partes interessadas, maior envolvimento da alta direção e maior flexibilidade na exigência de procedimentos documentados (BUREAU VERITAS, 2015).

\subsection{Relação homem e meio ambiente}

\subsubsection{Contextualização}

Uma breve contextualização será apresentada para compreender os principais tópicos relacionados a ISO 14001 para que posteriormente seja possível relacionar os requisitos desse padrão normativo com a sustentabilidade empresarial.

\subsubsection{O meio ambiente: marcos e eventos internacionais}

Os problemas ambientais provocados pelas ações antrópicas decorrentes do uso e exploração dos recursos naturais para produção de bens e serviços em grande escala, o despejo de materiais, degradação do meio ambiente e o incentivo exagerado ao consumismo tem gerado quantidades vultosas de resíduos, desperdício de água, perda de biodiversidade, contaminação de solos férteis e o dispêndio de energia que, consequentemente ameaça a capacidade de suporte do planeta (BARBIERI, 2011).

Diante desse contexto, constatou-se uma crescente conscientização envolvendo os setores públicos, privados, sociedade civil e intelectual que influenciaram na realização de encontros que tiveram o objetivo de discutir as questões ambientais e o futuro do planeta.

Em 1968 ocorreu a primeira reunião do Clube de Roma realizada por um pequeno grupo composto por intelectuais, setor público, privado e sociedade civil que tinham como objetivo discutir o consumo de recursos não-renováveis e problemas ambientais da época e consequentemente o futuro da humanidade (THE CLUB OF ROME, 2014).

Em 1972 foi publicado um livro denominado "Os limites do Crescimento" desenvolvido por cientistas do Instituto de Tecnologia de Massachusetts (MIT) 
apresentando alguns cenários futuros baseados em modelagem computacional que simulou a interação de cinco subsistemas globais sendo eles: população, produção de alimentos, produção industrial, poluição e consumo de recursos naturais não renováveis (TURNER, 2008).

A publicação salienta que o crescimento desenfreado da economia mundial levaria o planeta ao colapso em algum momento do século 21, mas que essa preposição pode ser evitada se existir uma combinação de mudanças de atitudes, políticas e desenvolvimento de novas tecnologias que contribuam para minimização dos impactos ambientais (MEADOWS et al., 1972).

No estudo realizado por Turner (2008) o autor compara dados históricos reais levantados entre 1970 a 2000 e constata que sua pesquisa apoia o modelo apresentado no livro e que o sistema mundial está em uma trajetória insustentável a menos que ocorra uma redução substancial e rápida no comportamento de consumo em combinação com o progresso tecnológico.

Ainda em 1972 foi organizado pelas Nações Unidas a Conferência de Estocolmo onde os países membros se comprometeram com a conservação e preservação do meio ambiente. Segundo Barbieri (2011) esse evento ficou marcado por duas opiniões distintas onde os países em desenvolvimento se viram no direito de utilizar os recursos naturais em prol do desenvolvimento econômico, enquanto os países desenvolvidos defendiam a conservação e controle da utilização dos recursos naturais.

No mesmo ano foi criado o Programa das Nações Unidas para o Meio Ambiente (PNUMA) que tem como objetivos monitorar continuamente o meio ambiente, recomendar ações para melhorar a qualidade de vida da população considerando as futuras gerações, identificar e alertar problemas ou ameaças que comprometa a integridade da população (ORGANIZAÇÃO DAS NAÇÕES UNIDAS, 2014a).

Em 1983 foi criado a Comissão Mundial sobre o Meio Ambiente e o Desenvolvimento (CMMAD/WCED) que formula e direciona propostas para solucionar as questões ambientais críticas. A partir desse encontro em 1987 essa comissão apresentou para o mundo o Relatório de Brundtland ou também conhecido como "Nosso Futuro Comum” (ORGANIZAÇÃO DAS NAÇÕES UNIDAS, 2014b).

Em 1992 ocorreu a segunda Conferência Mundial realizada pelas Nações Unidas denominada como Rio-92, Eco-92 ou Cúpula da Terra que reuniu 178 países que tinham como responsabilidade incluir as questões ambientais no centro das políticas 
econômicas e serem consideradas na tomada de decisão (NAÇÕES UNIDAS, 2012; STRONG, 1991).

Segundo Strong (1991) o tema central do encontro foi Meio Ambiente e o Desenvolvimento. $\mathrm{O}$ autor ainda salienta que para acabar com a discussão levantada em Estocolmo a Rio-92 incentivou a extinção das diferenças entre os países desenvolvidos e em desenvolvimento, sendo que esses deveriam receber apoio financeiro e tecnológico para alcançarem o modelo de desenvolvimento sustentável esperado na época. Ao final do evento foram assinados acordos (ex. Agenda 21) que contribuíram para a evolução do desenvolvimento sustentável.

Influenciada pelas crescentes discussões relacionadas ao Meio Ambiente em especial a Rio-92 em 1993 a International Organization for Standardization (ISO) criou um Comitê técnico ISO/TC 207 para elaborar a série ISO 14000. A série tem como objetivo prover as organizações elementos de um sistema da gestão ambiental (SGA) eficaz e auxiliá-las a alcançar seus objetivos ambientais e econômicos (ASSOCIAÇÃO BRASILEIRA DE NORMAS TÉCNICAS, 2004).

Os autores Cordani; Marcovith e Salati (1997) destacam que em 1997 a sociedade civil organizou um encontro denominado Rio+5 para discutir e avaliar os resultados e experiências bem-sucedidas, além de apontar as principais dificuldades e impasses dos cinco anos de esforços para implementar os acordos propostos pela Rio - 92.

Também em 1997 John Elkington lança um conceito de sustentabilidade que complementa o anterior que foi aceito mundialmente baseado no "triple botton line" que considera aspectos sociais e econômicos ligados ao meio ambiente (ELKINGTON, 2001).

Em 1997 foi realizada a terceira Conferência da Partes sobre Mudanças Climáticas que estabeleceu o Protocolo de Kyoto onde os países membros que participaram da Rio 92 se comprometeram a combater o aquecimento global, através da diminuição da emissão de gases do efeito estufa. O Protocolo reconhece que os países desenvolvidos são os principais responsáveis pelos elevados níveis de gases na atmosfera, sendo assim, seu comprometimento em diminuir a emissão de gases do efeito estufa é maior comparado com países em desenvolvimento (UNITED NATIONS, 2014).

Em 2000 foi realizada a Cúpula do Milênio que originou a Declaração do Milênio das Nações Unidas que possui 8 objetivos que deverão ser alcançadas até dezembro de 2015 são eles: erradicar a extrema pobreza e a fome; atingir o ensino básico universal; 
promover a igualdade entre os sexos e a autonomia das mulheres; reduzir a mortalidade infantil; melhorar a saúde materna; combater o HIV/AIDS, a malária e outras doenças; garantir a sustentabilidade ambiental; e estabelecer uma parceria mundial para o desenvolvimento (PROGRAMA DAS NAÇÕES UNIDAS PARA O DESENVOLVIMENTO, 2012).

Em 2012 foi realizado a Rio+20 que propôs a renovação do compromisso político com o desenvolvimento sustentável, por meio da avaliação do progresso e das lacunas na implementação das decisões adotadas pelas principais cúpulas sobre o assunto e do tratamento de temas novos e emergentes (BRASIL, 2011). No entanto, os autores Viola; Franchini (2012) apontam que esse encontro não atendeu as expectativas previstas não sendo bem sucedida. Ainda, segundo os autores na agenda da Rio+20 não havia pretensão de estabelecer acordos rigorosos e legalmente vinculante que os membros devessem seguir, sendo assim, a cúpula foi incapaz de oferecer um progresso no paradigma da governança do desenvolvimento sustentável, já que não discutiu efetivamente temas centrais como por exemplo a Economia Verde.

\subsubsection{Gestão Ambiental Empresarial}

A gestão ambiental empresarial é um conjunto de práticas, programas e políticas administrativas e operacionais que considera a minimização e quando possível a eliminação dos impactos ambientais através do planejamento, implementação, realocação ou desativação de atividade degradantes ao meio ambiente, incluindo todas as fases do ciclo de vida de um produto (NETO; CAMPOS; SHIGUNOV, 2009).

Esse conceito também pode ser definido como as diretrizes e as atividades administrativas e operacionais realizadas com o objetivo reduzir ou eliminar danos ou problemas causados pelas ações humanas (BARBIERI, 2011). Diante desse contexto, dependendo de como a empresa atua perante as questões ambientais ela pode desenvolver-se em três abordagens diferentes controle da poluição, prevenção da poluição e estratégica (BARBIERI, 2011).

Nos anos 60 e 70 as questões ambientais que começaram a surgir no ambiente industrial possuíam um caráter de tratamento pontual e desvinculado de qualquer preocupação com os processos de desenvolvimento. As ações para resolver alguns problemas ambientais eram apenas lançar os poluentes o mais longe possível da fonte poluidora, ou seja, somente dispersa-los. Com o processo de industrialização acelerado 
os empresários acreditavam que os danos ambientais e poluição deveriam ser assumidos pela sociedade em favor do desenvolvimento econômico (BARBIERI, 2011).

A partir dos anos 70 se observou a busca de uma nova relação entre o meio ambiente e o desenvolvimento econômico, através de ações governamentais de caráter corretivo que eram fragmentadas apoiadas em medidas integradas e de baixa eficiência. A poluição gerada pelas indústrias era controlada e remediada no final dos processos "end of the pipe" (fim de tubo) e o cumprimento da legislação ocorria apenas quando obrigatório. Nessa época, os empresários não possuíam nenhuma visão das oportunidades decorrentes de uma gestão ambiental eficiente e viam as questões ambientais como um gasto adicional a seus processos (BARBIERI, 2011).

Nos anos 90 teve início a abordagem estratégica da prevenção a poluição que apresenta uma visão proativa na qual a empresa busca atuar sobre os produtos e processos a fim de prevenir a geração da poluição, empreendendo ações com vistas a uma produção mais eficiente e, portanto, poupadora de materiais e energia em diferentes fases do processo de produção e comercialização. É uma abordagem vantajosa para as organizações, pois aumenta a produtividade devido à redução de poluentes o que permite reduzir custos, produzir mais bens e serviços com mais insumos (BARBIERI, 2011).

Observa-se que com o passar do tempo as empresas vem se preocupando com as questões ambientais e estão adotando concepções administrativa e tecnológicas que auxiliam para o alcance da sustentabilidade. Além disso, as organizações estão sendo pressionadas pelas partes interessadas (sociedade, mercado e governo) a internalizar suas externalidades, ou seja, reduzir e minimizar os impactos ambientais negativos para que esses não afetem as partes interessadas.

\subsubsection{Sistema de Gestão Ambiental (SGA)}

Um Sistema de Gestão Ambiental é um dos meios que as empresas podem adotar para internalizar suas externalidades. Um SGA pode ser utilizado para desenvolver e implementar sua política ambiental e para gerenciar os aspectos ambientais, incluindo estrutura organizacional, atividades de planejamento, responsabilidades, práticas, procedimentos, processos e recursos (ASSOCIAÇÃO BRASILEIRA DE NORMAS TÉCNICAS, 2004). Segundo Barla (2007) um SGA pode ser definido como um conjunto de regras e procedimentos que tem como objetivo diminuir os impactos ambientais das organizações. 
O primeiro modelo de gestão ambiental formal denominado Programa de Atuação Responsável (Responsible Care Program) foi criado em 1984 no Canadá por uma Associação de Indústrias Químicas (Chemical Manufacturers Association). É um programa voluntário e não certificável que visa a melhora na performance em saúde, segurança, qualidade ambiental e atendimento das necessidades das partes interessadas. Estabelece diretrizes para a gestão segura de produtos químicos e atualmente é utilizada por empresas do setor químico em mais de 60 países (RESPONSABLE CARE, 2014).

Em seguida em 1989 empresas alemãs perceberam que proteger o meio ambiente poderia tornar-se uma vantagem competitiva e George Winter desenvolveu o modelo voluntário e não certificável de Sistema de Gestão Ambiental denominado Winter. O modelo aponta seis razões para que as empresas adotem um sistema de gestão sendo eles: sobrevivência humana, consenso público, oportunidade de mercado, redução de riscos, redução de custos e integridade pessoal (NETO; CAMPOS; SHIGUNOV, 2009).

No mesmo ano em 1989 a Coalisão para as Economias Responsáveis pelo Meio Ambiente (Coalition for Environmentally Responsible Economies - CERE) estabeleceu princípios como proteção da biosfera, uso sustentável de recursos naturais, redução e disposição de resíduos, conservação de energia, redução de riscos, comercialização de produtos e serviços seguros, restauração ambiental, informações a comunidade, compromisso de administração e auditorias e relatórios (CERE, 2014).

Em 1993 foi criado na União Europeia o Sistema Europeu de Eco-Gestão e Auditorias (Eco-Management and Audit Scheme - EMAS) que define critérios para certificação ambiental de processos industriais (EUROPEAN COMMISSION, 2014).

Em 1993 a International Organization for Standardization (ISO) criou um Comitê técnico ISO/TC 207 para elaborar a série ISO 14000 que tem como objetivo prover as organizações de elementos de um sistema da gestão ambiental (SGA) eficaz que possam ser integrados a outros requisitos da gestão e auxiliá-las a alcançarem seus objetivos ambientais e econômicos. As organizações de diversos segmentos estão cada vez mais interessadas em implementar o Sistema de Gestão Ambiental para demonstrar seu desempenho ambiental, por meio do controle dos aspectos ambientais e controle dos possíveis impactos que suas atividades possam trazer para o meio ambiente (ASSOCIAÇÃO BRASILEIRA DE NORMAS TÉCNICAS, 2004).

A norma ISO 14001 é o padrão mais adotado por organizações que desejam implementar um sistema de gestão ambiental. É um padrão certificável e possui ampla 
divulgação mundial e compatibilidade com demais normas (BANSAL; BOGNER, 2002).

No Brasil o número de certificações ISO 14001 no ano de 2013 (3.695) foi superior se compararmos com o ano de 2012 (3300 certificados) como mostra a figura 4.

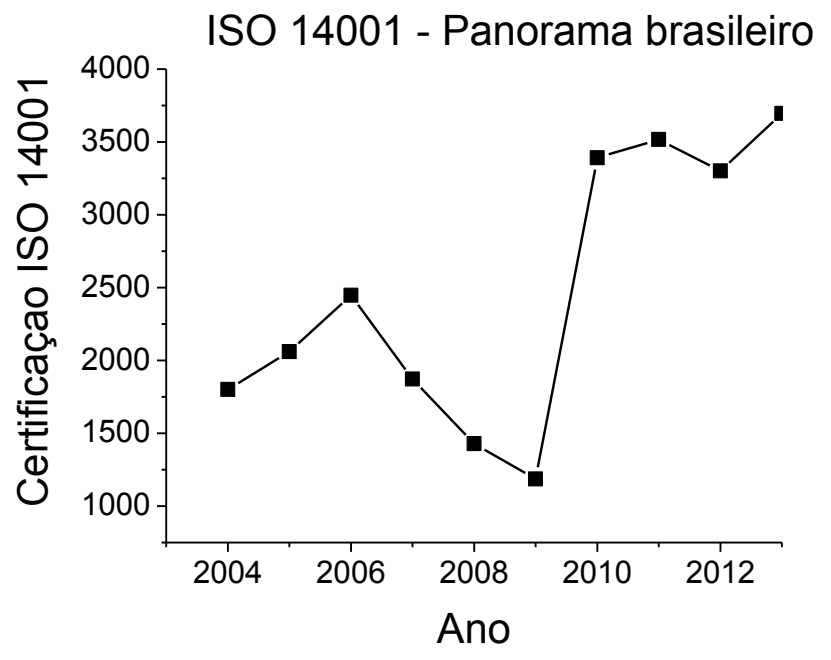

Figura 4. Evolução temporal do número de certificações ISO 14001 no Brasil (INTERNATIONAL ORGANIZATION FOR STANDARDIZATION, 2014).

De acordo com a International Organization for Standardization (2014) no final de 2013 o total de certificados ISO 14001 emitidos foi de 301.647 no mundo. No final do ano de 2012 o número total era de 284.654 certificados ISO 14001 distribuídos pelo mundo. Sendo assim, observa-se um aumento de 16.993 novos certificados como mostra a Figura 5.

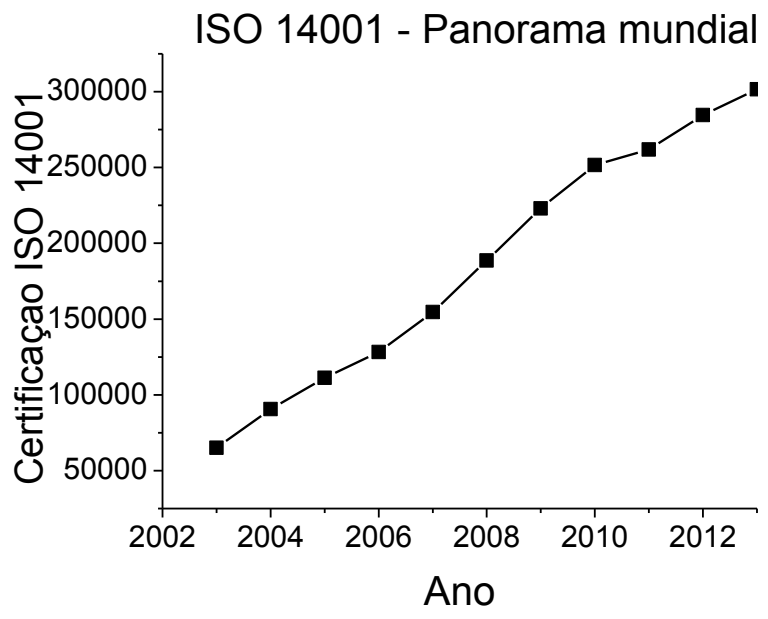

Figura 5. Número de certificados ISO 14001 - panorama mundial (INTERNATIONAL ORGANIZATION FOR STANDARDIZATION, 2014). 
Diante desse contexto, observa-se que empresas multinacionais residentes em países desenvolvidos que adotam a padronização ISO 14001 e investem em recursos (financeiro e humanos) nas filiais incentivam essas novas empresas a adotarem práticas corporativas incluindo a certificação do sistema de gestão ambiental (PRAKASH; POTOSKI, 2007). Geralmente as filiais estão localizadas em países onde a legislação ambiental vigente não é rigorosa, com isso as novas empresas passam a desconsiderar as exigências legais estabelecidas em seus países que são menos restritas influenciando todos os stakeholders (PRAKASH; POTOSKI, 2007). Os autores Prakash e Potoski (2006) afirmam que o livre comércio auxilia na disseminação da norma ISO 14001 se os exportadores possuírem a certificação. Sendo assim, o mercado pode servir como um instrumento importante para incentivar a difusão de modelos de governança e práticas organizacionais incluindo os padrões ISO.

\subsubsection{Sistema de Gestão Ambiental - ABNT NBR ISO 14001:2004}

A ISO 14001 foi criada em 1996 influenciada pelas discussões levantadas na Eco92 e revisada em 2004. Atualmente (Julho/2015) está passando pelo processo revisão. Pode ser compreendida como um padrão internacional que define critérios para sistemas de gestão ambiental (SGA) incluindo requisitos para a estrutura organizacional, práticas, processos, recursos, responsabilidades e procedimentos a fim de sistematizar o sistema em uma organização (BANSAL; BOGNER, 2002).

Esse padrão pode ser adotado pelas empresas voluntariamente. Além disso, a norma é baseada nos princípios da melhoria contínua e utiliza o ciclo PDCA (ASSOCIAÇÃO BRASILEIRA DE NORMAS TÉCNICAS, 2004)

Esta norma tem como objetivo especificar os requisitos de um sistema de gestão ambiental orientando uma organização a implementar uma política e objetivos considerando os requisitos legais e ambientais (ASSOCIAÇÃO BRASILEIRA DE NORMAS TÉCNICAS, 2004) como mostra o quadro 4.

\section{Requisitos gerais}

Essa sessão tem a função de estabelecer as obrigatoriedades no cumprimento de todos os requisitos descritos na norma (NETO, TAVARES, HOFFMANN, 2013). 


\begin{tabular}{|c|c|c|}
\hline Cláusula & & Título do requisito \\
\hline 4.1 & & Requisitos gerais \\
\hline 4.2 & & Política ambiental \\
\hline \multirow{3}{*}{4.3} & \multirow{3}{*}{ Planejamento } & 4.3.1 Aspectos ambientais \\
\hline & & 4.3.2 Requisitos legais e outros \\
\hline & & 4.3.3 Objetivos, metas e programa(s) \\
\hline \multirow{7}{*}{4.4} & \multirow{7}{*}{ Implementação e operação } & 4.4.1 Recursos, funções, responsabilidades e autoridades \\
\hline & & 4.4.2 Competência, treinamento e conscientização \\
\hline & & 4.4.3 Comunicação \\
\hline & & 4.4.4 Documentação \\
\hline & & 4.4.5 Controle de documentos \\
\hline & & 4.4.6 Controle operacional \\
\hline & & 4.4.7 Preparação e resposta à emergência \\
\hline \multirow{5}{*}{4.5} & \multirow{5}{*}{ Verificação } & 4.5.1 Monitoramento e medição \\
\hline & & 4.5.2 Avaliação do atendimento a requisitos legais e outros \\
\hline & & 4.5.3 Não conformidade, ação corretiva e ação preventiva \\
\hline & & 4.5.4 Controle de registros \\
\hline & & 4.5.5 Auditoria interna \\
\hline 4.6 & Análise & 4.6 Análise pela administração \\
\hline
\end{tabular}

Quadro 4. Estrutura da norma ISO 14001: 2004 (ASSOCIAÇÃO BRASILEIRA DE NORMAS TÉCNICAS, 2004).

\section{Política ambiental}

Essa sessão aborda a política ambiental que deve conter as diretrizes da organização com relação ao comprimento dos requisitos estabelecidos pela norma. Deve incluir o comprometimento com a melhoria contínua, prevenção da poluição, atendimento aos requisitos legais, além disso, deve ser comunicada a todas as partes interessadas (NETO, TAVARES, HOFFMANN, 2013).

\section{Planejamento}

Nessa sessão é necessário que a organização identifique os aspectos e impactos ambientais significativos considerando o escopo delimitado. Incluir o atendimento aos requisitos legais e outros que as organizações julgam necessários. Além disso, devem-se estabelecer objetivos, metas e programas para garantir a manutenção do sistema de gestão (NETO, TAVARES, HOFFMANN, 2013).

\section{Implementação e operação}

A implementação do sistema de gestão ambiental em uma organização só é possível se todos da organização estiverem comprometidos e engajados no processo de 
certificação. Os requisitos dessa sessão têm como objetivo assegurar recursos e condições necessárias para uma efetiva implementação (NETO, TAVARES, HOFFMANN, 2013).

\section{Verificação}

Esta sessão agrupa requisitos que tem como objetivo coletivo garantir o atendimento as diretrizes estabelecidas no sistema de gestão ambiental por meio de tratamento de não conformidades reais e potenciais, atendimento a requisitos legais, avaliação do desempenho ambiental, entre outros (NETO, TAVARES, HOFFMANN, 2013).

\section{Análise}

Nesta etapa a alta direção deve assegurar que o SGA se mantenha adequado, pertinente e eficaz (NETO, TAVARES, HOFFMANN, 2013).

O estudo realizado por Gonzáles-Benito e Gonzáles-Benito (2008) que teve como objetivo explorar as ligações entre as práticas e comportamentos desenvolvidos na função de operação e a implementação da norma ISO 14001 (foram analisados dados empíricos fornecidos por 184 fábricas espanholas) conclui que empresas que possuem funções de operações proativas (tendência de uma organização adotar todas as práticas, ferramentas ou sistemas de gestão avançados, modernos e promissores dentro das funções de produção e operações) são mais propensas a adotar a ISO 14001. Essas empresas buscam originalidade e inovação, sendo assim, a certificação pode ser uma diferencial na obtenção de novos mercados.

Segundo Jiang e Bansal (2003) em seu estudo que teve como objetivo identificar as razões pelas quais as empresas canadense de papel e celulose certificaram-se ISO 14001 (foram entrevistado gestores ambientais de 16 empresas) identificou que os principais fatores que levam as organizações a adotarem a norma ISO 14001 estão relacionados com as influências externas (demanda de mercado e pressões institucionais) e internas que refletem na opção estratégica da empresa em como lidar com as questões ambientais. Os autores Heras-Saizarbitoria; Landín; Molina-Azorín (2011) em seu estudo que teve como objetivo analisar as motivações e os benefícios obtidos por empresas (foram analisados 214 empresas espanholas), através da certificação ISO 14001 complementam que empresas que adotam a certificação 
considerando os fatores internos possuem maiores benefícios se comparadas com aquelas que buscam a certificações apenas objetivando os fatores externos.

Com as crescentes discussões a respeito das questões ambientais as partes interessadas passaram a preocupar-se com a sustentabilidade dentro das organizações, ou seja, as pressões externas de clientes estrangeiros e acionistas que visavam lucro de longo prazo induziram as empresas adotarem o padrão (NISHITANI, 2009). Os autores Jiang e Bansal (2003) concluíram que muitas empresas não obterão o certificado ISO 14001 se não sofrerem com pressões institucionais e das partes interessadas e sugerem que empresas certificadas pressionem seus fornecedores a comprometerem-se ambientalmente criando um elo em toda a cadeia de suprimento.

Em um estudo realizado no Japão que teve como objetivo estimar os efeitos da certificação ISO 14001 no gerenciamento da cadeia de abastecimento apontou que empresas certificadas ISO 14001 são 40\% mais propensas a avaliar o desempenho ambiental de seus fornecedores e 50\% mais propensas a exigir que seus fornecedores se comprometam em adotar práticas ambientais. Para realização desta pesquisa foram entrevistados 1.499 japoneses que trabalhavam em fabricas que possuíam mais de 50 funcionários e que fossem responsáveis por atividades ambientais nas organizações (ARIMURA; DARNALL; KATAYAMA, 2011). Sendo assim, mesmo que a ISO 14001 não melhore o desempenho ambiental de uma empresa, sua adoção pode afetar as ações ambientais de outras organizações promovendo práticas de Green Supply Chain Management (GSCM).

Em um estudo realizado com gestores e fornecedores de duas empresas multinacionais suecas e certificadas ISO 14001 que teve como objetivo entender o papel da ISO 14001 em práticas da cadeia de suprimento demonstrou que as decisões no momento da compra não consideraram as questões ambientais envolvidas e muitas vezes o gerente de compras não possuía conhecimento suficiente da norma. Tornou-se evidente que as decisões sobre compras de matéria-prima não foram tomada juntamente com o departamento de meio ambiente. Observa-se que a comunicação é um dos principais desafios a serem superados internamente para que as questões ambientais passem a ser consideradas efetivamente nas organizações e em toda a cadeia de suprimento (NAWROCKA; BRORSON; LINDHQVIST, 2009).

Diante desse contexto, o estudo de Babakri; Bennett; Franchetti (2003) que teve como objetivo identificar fatores críticos na implementação de um sistema de gestão ambiental baseado na ISO 14001 aponta que os elementos que exigem mais esforços no 
momento da implementação são: identificação dos aspectos e impactos ambientais, elaboração e controle de documentos, treinamentos, processo de auditoria, controle operacional, inserção de programas de gestão ambiental e estabelecimento e cumprimento dos objetivos e metas. Além disso, os autores apontam as barreiras encontradas no processo de implementação que são: altos custos da certificação, falta de recursos humanos e financeiros, incerteza sobre os benefícios que a implementação irá trazer para as organizações, falta de comprometimento da alta direção, resistência a mudança e melhorias e falta de comprometimento relacionado às questões ambientais. Esse estudo foi realizado em 177 empresas Norte Americanas de vários segmentos (ex. automotivo, têxtil, químico, entre outros) certificadas ISO 14001.

O estudo realizado por Bansal e Bogner (2002) que teve como objetivo identificar com base em considerações econômicas e institucionais os benefícios de implementar a ISO 14001 e identificar quando a certificação pode ser apropriada de acordo com cada contexto empresarial apontou que os benefícios decorrentes do processo de certificação, manutenção e renovação do certificado de um sistema de gestão ambiental (ISO 14001) devem ser significativos o suficiente para justificar os custos financeiros envolvidos.

Um SGA adotado de maneira correta pode permitir que as empresas alcancem maior eficiência e eficácia organizacional, através da diminuição dos custos e dos impactos ambientais. Além disso, empresas que adotaram a ISO 14001 obtêm vantagens competitivas e retornos financeiros superiores se comparado com aquelas que não possuem o certificado (BANSAL; BOGNER, 2002).

Ainda os autores Heras-Saizarbitoria; Landín; Molina-Azorín (2011) afirmam que os benefícios estão relacionados ao comprimento da legislação. Além disso, empresas que adotam essa norma melhoram seu desempenho ambiental e diminui a poluição gerada (ARIMURA; DARNALL E KATAYAMA, 2008). O aumento da fatia do mercado também foi apontado como um ponto positivo da adoção da certificação (BANSAL; HUNTER, 2003).

Apesar das crescentes pressões institucionais referentes à adoção da ISO 14001 alguns autores questionam a eficiência deste padrão como mostra Boiral e Henri (2012). Um estudo realizado anteriormente por Boiral (2007) em nove organizações canadenses certificadas ISO 14001 demonstrou que as principais melhorias relacionadas à adoção desse padrão foram de natureza técnica e administrativa. Alguns anos atrás Jiang e Bansal (2003) concluíram que a certificação contribui para a manutenção de um sistema de gestão ambiental, no entanto a padronização leva a uniformidade e não excelência. 
Diante desse contexto, essas melhorias não garantem a minimização ou eliminação dos impactos ambientais negativos.

Em seu estudo Barla (2007) pesquisou o comportamento das variáveis Demanda Bioquímica de Oxigênio (DBO) e sólidos totais suspensos em indústrias de papel e celulose no Quebec (Canadá) e concluíram que apesar da DBO ter diminuído (9\%) não foram identificadas mudanças significativas na quantidade de sólidos totais em suspensão. No mesmo estudo foi realizada uma comparação entre empresas não certificadas e aquelas que adotaram a ISO 14001 e os resultados apontam que empresas que não possuíam certificado apresentaram uma redução de emissão superior se comparada as que certificadas. Sendo assim, o autor conclui que muitas vezes a ISO 14001 é ineficaz na redução das externalidades ambientais.

Atualmente (julho/2015) a ISO 14001 está passando pelo processo de revisão. As principais mudanças que ocorreram estão relacionadas a importância de considerar as questões ambientais no planejamento estratégico da organização, necessidade de considerar as partes interessadas, as lideranças devem assumir a responsabilidade de promover a gestão ambiental, maior ênfase na melhoria do desempenho (redução de emissões, resíduos, entre outros), preocupação com o fim da vida do produto (descarte e tratamento), comunicação interna e externa igualitária, entre outras (FONSECA, 2015).

\subsection{Responsabilidade social}

Uma breve contextualização será apresentada para compreender os principais tópicos relacionados a NBR 16001 para que posteriormente seja possível relacionar os requisitos desse padrão normativo com a sustentabilidade corporativa.

\subsubsection{Contextualização}

Em 1948 foi promulgada e adotada pelas Nações Unidas a Declaração Universal dos Direitos Humanos que estabelece princípios para elaboração de políticas públicas e privadas que considerem as questões sociais. A declaração é formada por 30 artigos que abordam as seguintes temáticas: liberdade e igualdade de direitos independente se sua raça, cor, sexo, língua, religião, opinião pública, origem nacional ou social, entre outros; todos têm o direito a vida e a segurança; ninguém poderá ser escravo; ninguém deverá ser submetido a tortura ou crueldade; reconhecimento perante a lei; todos tem o direito a justiça; liberdade de locomoção; direito a nacionalidade; direito de matrimônio; direito de propriedade; liberdade de pensamento, opinião e religião; direito de saúde, educação, 
alimentação, vestuário, habitação, cuidados médico e segurança em caso de desemprego; e a sociedade tem o dever de respeitar esses direitos (ORGANIZAÇÃO DAS NAÇÕES UNIDAS, 1948). Sendo assim, empresas que localizarem-se em países que adotaram esses princípios legalmente deverão atendê-los (BARBIERI; CAJAZEIRA, 2009).

Em 1996 a Organização das Nações Unidas (ONU) estabeleceu o Pacto Internacional sobre Direitos Civis e Políticos (enfatiza questões como discriminação e direitos das minorias - conjunto de indivíduos usualmente discriminados, segregados, e excluídos do convívio social tais como negros, pessoas com deficiência, mulheres, índios, idosos, homoafetivos, imigrantes, entre outros) e o Pacto Internacional de Direitos Econômicos, Sociais e Culturais (enfatiza questões que envolvam trabalho condições de trabalho decente, igualdade entre homens e mulheres no ambiente de trabalho, entre outros - e assistência e proteção a todas as crianças e adolescentes) que detalham e estabelecem mecanismos para o alcance dos princípios estabelecidos na Declaração dos Direitos Humanos (ORGANIZAÇÕES DAS NAÇÕES UNIDAS, 1996a; ORGANIZAÇÕES DAS NAÇÕES UNIDAS, 1996b).

Em 2000 a ONU reúne em Nova Iorque 191 países com o intuito de discutir a desigualdade existem no mundo e firmar acordos e objetivos que devem ser alcançado pelos países membros. Surge a partir desse momento a Declaração do Milênio que possui 8 objetivos que são: 1) Erradicar a extrema pobreza e a fome; 2) Atingir o ensino básico fundamental; 3) Promover igualdade entre os sexos e autonomia das mulheres; 4) Reduzir a mortalidade infantil; 5) Combater a AIDS, a malária e outras doenças; 6) Melhorar a saúde das gestantes; 7) Garantir a sustentabilidade do planeta; e 8) Estabelecer uma parceria mundial para o desenvolvimento.

De acordo com Barbieri e Cajazeira (2009) esses princípios se implementados no ambiente empresarial poderão auxiliar no direcionamento das atividades filantrópicas e no alcance da doutrina da responsabilidade social.

\subsubsection{Responsabilidade social empresarial}

Discussões a respeito da temática responsabilidade social ocorrem desde o surgimento das empresas, mas somente recentemente essa temática passou a ser destaque em praticamente todos os setores da sociedade (BARBIERI; CAJAZEIRA, 2009). Segundo Carroll (1979) a responsabilidade social das empresas englobam as 
expectativas econômicas, legais, éticas e discriminatórias/filantrópica que a sociedade possui com relação as organizações.

Um dos principais autores que auxiliaram a acessão das discussões relacionadas a responsabilidade social no contexto corporativo (referindo-se a empresas que se constituem na forma de sociedade anônima de capital aberto, onde a administração está desvinculada dos proprietários) foi o economistas Friedman autor do livro Capitalismo e liberdade e ganhador do Prêmio Nobel em 1976 quando acusou a doutrina da responsabilidade social de subversiva (BARBIERI; CAJAZEIRA, 2009).

Segundo Friedman (1970) a responsabilidade social de uma empresa é gerar lucro. O autor afirma ainda que se o lucro estiver dentro da lei significa que as corporações estão produzindo bens ou serviços que gerarão benefícios para a sociedade e para o governo, sendo esse o responsável por resolver os problemas sociais existentes. Ainda afirma que o objetivo dos dirigentes é obter lucro para os acionistas e aqueles indivíduos que quiserem contribuir na resolução de problemas sociais, poderiam utilizar seus próprios recursos e não os das corporações, já que essas são artificiais e não possuem responsabilidades além das legais contrariando a ideia filantrópica empresarial.

No entanto, os acionistas não são os únicos interessados nas empresas existindo outras partes interessadas que não se preocupam somente com os lucros e benefíciosfinanceiros, ou seja, analisando a posição de Friedman perante esse assunto as questões que envolvem a coletividade não são consideradas (BARBIERI; CAJAZEIRA, 2009).

Diante desse contexto, as partes interessadas (stakeholder) passaram a pressionar as empresas a respeitar os valores sociais, éticos e eliminar os impactos sociais e ambientais provenientes de seus processos produtivos (PENIDO et al., 2008). De acordo com a Associação Brasileira de Normas Técnicas (2012a) stakeholders são "individuo ou grupo que tem um interesse em quaisquer decisão ou atividades de uma organização". Ou seja, as partes interessadas podem ser grupos de interesses que possuam um envolvimento direto ou indireto com as atividades das empresas como, por exemplo: cliente, sindicatos, fornecedores, investidores, autoridades governamentais, entre outros (BARBIERI; CAJAZEIRA, 2009).

A ABNT (2012) aponta a necessidade do engajamento das partes interessadas. Esse processo envolve diálogo (diálogo pode ocorrer através reuniões, conferências, audiências publicas, workshops, comitês consultivos, através da internet, entre outros). Dentre as razões apontadas pela ABNT para engajar as partes interessadas estão: aumentar a compreensão das organizações a respeito dos efeitos que suas decisões 
afetam as partes interessadas e conciliar conflitos que envolvam as empresas, as partes interessadas e a sociedade como um todo.

De acordo com Barbieri e Cajazeira (2009) as principais dificuldades de implementar as práticas de responsabilidade social empresarial estão relacionadas ao mapeamento das partes interessadas, seus direitos, suas expectativas, obrigações; nas diferentes visões a respeito da relação entre as empresas e os stakeholder; e na inserção de todas essas questões no ambiente empresarial sustentável financeiramente.

Para auxiliar as empresas a ultrapassarem esses obstáculos Carroll (1991) desenvolveu um esquema que considerou a desagregação de seus componentes. Esse esquema foi representado por uma pirâmide que foi dividida em 4 dimensões que são:

Econômica - o objetivo principal de uma organização é gerar lucro através da oferta de bens e serviços para manter-se competitivas no mercado;

$>$ Legal - está relacionada ao comprimento de requistos legais e outros necessários para que as empresas mantenham sua reputação e boa imagem perante as partes interessadas;

> Ética - representa o comportamento ético que a sociedade espera que as organizações atendam. Segundo a Associação Brasileira de Normas Técnicas (2010b) comportamento ético é definido como "comportamento que esteja de acordo com os princípios aceitos de uma conduta moral e correta no contexto de uma situação específica e que seja consistente com normas internacionais de comportamento" (pag. 2). A má conduta ética de gestores que praticam a corrupção, falsificação, biopirataria, incentivo ao trabalho escravo, sonegação, desvio de verbas, doações a campanhas eleitorais, entre outros estão sendo repugnados pelas partes interessadas, ou seja, a sociedade está exigindo que as organizações adotem uma postura ética (MORAES, et al. 2008); e

Filantrópica - A dimensão filantrópica onde as organizações buscam resolver problemas sociais. A princípio as ações relacionadas às questões sociais eram baseadas na filantropia, onde empresários bem sucedidos doavam para a sociedade parte de seus ganhos. A filantropia parte de uma atitude individual, voluntária, de caráter similar a caridade e possui base assistencialista. Diferentemente da filantropia a responsabilidade social parte de ações coletivas que buscam fomentar a cidadania para todas as partes interessadas (MELO- 
NETO; FROES, 2001). A responsabilidade social pode ser exercida de duas formas através de projetos sociais que são voltados para resolução de problemas voltados para a população e através de ações comunitárias que é a participação das empresas em programas sociais em parceria com governos, lideres comunitários, ONGs, entre outros (MELO-NETO; FROES, 2001).

Posteriormente Schwartz e Carroll (2003) aperfeiçoaram esse modelo e resumiram para três domínios que são: econômico (refere-se a atividades voltadas para obtenção de lucro), legal (refere-se as respostas dadas pelas empresas a respeito de questões legais) e ético (refere-se às responsabilidades das empresas em atenderem os anseios e expectativas das partes interessadas). Para criação do novo modelo foi utilizado 3 círculos que possuem intersecções.

Diante dessa abordagem as empresas deixaram de preocupar-se somente com obtenção de lucro e passaram a preocupar-se com o bem estar das partes interessadas, preservação do meio ambiente, compromissos éticos e transparência (PENIDO et al., 2008). Segundo Penido et al., (2008) os benefícios associados a empresas que adotam a responsabilidade social são: satisfação do consumidor, melhoria da imagem corporativa, motivação interna, engajamento da comunidade e de outras partes interessadas, entre outros.

Para ajudar empresas a incorporarem a doutrina da responsabilidade social em 2010 a International Organization for Standardization publicou a norma ISO 26000 Diretrizes sobre Responsabilidade Social que fornece orientação sobre os princípios da responsabilidade social reconhece o engajamento das partes interessadas, temas centrais e as questões sociais (ASSOCIAÇÃO BRASILEIRA DE NORMAS TÉCNICAS, 2010b).

Os princípios da responsabilidade social apontados pela norma são:

Accountability onde as organizações prestem contas e se responsabilizem pelos impactos na sociedade, meio ambiente e economia;

$>$ Transparência nas decisões e atividades que impactam todos as partes interessadas;

$>$ A organização deve comprometer-se em manter o comportamento ético;

As partes interessadas devem ser respeitadas, consideradas e ouvidas;

$>$ Garantia de respeito pelo estado de direito; 
Respeitar as normas internacionais de comportamento; e

$>$ Sobretudo garantir o atendimento dos direitos humanos.

Os temas centrais da responsabilidade social são:

Governança organizacional;

$>$ Direitos humanos;

$>$ Práticas de trabalho;

$>$ Meio ambiente;

$>$ Práticas legais de operação;

$>$ Questões relativas ao consumidor; e

Envolvimento e desenvolvimento da comunidade.

A norma ISO 26000 não é certificável, no entanto, o Brasil foi um dos países pioneiros a desenvolver um padrão passível de certificação a NBR 16001 que será apresentado a seguir.

\subsubsection{Sistema de Gestão da Responsabilidade Social (SGRS) - ABNT ISO} 16001:2012.

A NBR 16001 é uma norma brasileira de passível certificação criada pela Associação Brasileira de Normas Técnicas em conjunto com partes interessadas como governo, setor produtivo, organizações não governamentais, entidades de classe e academia que teve sua primeira versão lançada em 2004 e revisada em 2012.

Esta norma pretende auxiliar as organizações a contribuirem para 0 desenvolvimento sustentável e visa estimulá-las a irem além da conformidade legal, posto que esta é uma obrigação fundamental de qualquer organização e parte essencial de sua responsabilidade social (ASSOCIAÇÃO BRASILEIRA DE NORMAS TÉCNICAS, 2012a). No Brasil atualmente (Abril, 2015) há 17 empresas certificadas e 3 organismos de certificação (INMETRO, 2014).

Essa norma é aplicável a qualquer tipo e porte de organização e adéqua-se a diferentes condições geográficas, culturais e sociais brasileiras (ASSOCIAÇÃO BRASILEIRA DE NORMAS TÉCNICAS, 2012a). A norma foi desenvolvida com base no ciclo PDCA (Plan, Do, Check e Act), sendo que os requisitos da norma podem ser relacionados com cada uma das etapas do ciclo, como mostra a quadro 5. 


\begin{tabular}{|c|c|c|}
\hline Cláusulas & & Título do requisito \\
\hline 3.1 & & Requisitos gerais \\
\hline 3.2 & & Política da Responsabilidade social. \\
\hline \multirow{7}{*}{3.3} & \multirow{7}{*}{ Planejamento. } & 3.3.1 Identificação das partes interessadas. \\
\hline & & 3.3.2 Temas centrais da responsabilidade social e suas questões. \\
\hline & & 3.3.3 Due diligence. \\
\hline & & 3.3.4 Identificação de oportunidades de melhoria e inovação. \\
\hline & & 3.3.5 Requisitos legais e outros. \\
\hline & & 3.3.6 Objetivos, metas e programas. \\
\hline & & 3.3.7 Recursos, funções, responsabilidades e autoridades. \\
\hline \multirow{5}{*}{3.4} & \multirow{5}{*}{$\begin{array}{l}\text { Implementação e } \\
\text { operações. }\end{array}$} & 3.4.1 Competência, treinamento e conscientização. \\
\hline & & 3.4.2 Engajamento das partes interessadas. \\
\hline & & 3.4.3 Comunicação. \\
\hline & & 3.4.4 Tratamento de conflitos ou desavenças. \\
\hline & & 3.4.5 Controle operacional. \\
\hline \multirow{4}{*}{3.5} & \multirow{4}{*}{$\begin{array}{l}\text { Requisitos de } \\
\text { documentação. }\end{array}$} & 3.5.1 Generalidades. \\
\hline & & 3.5.2 Manual do sistema de gestão da responsabilidade social. \\
\hline & & 3.5.3 Controle de documentos. \\
\hline & & 3.5.4 Controle de registros. \\
\hline \multirow{5}{*}{3.6} & \multirow{5}{*}{$\begin{array}{l}\text { Medição, análise e } \\
\text { melhoria. }\end{array}$} & 3.6.1 Monitoramento e medição. \\
\hline & & 3.6.2 Avaliação do atendimento a requisitos legais e outros. \\
\hline & & 3.6.3 Não conformidade e ações corretivas e preventivas. \\
\hline & & 3.6.4 Auditoria interna. \\
\hline & & 3.6.5 Análise pela Alta Direção. \\
\hline
\end{tabular}

Quadro 5. Estrutura da norma NBR 16001:2012 (ASSOCIAÇÃO BRASILEIRA DE NORMAS TÉCNICAS, 2012a).

\section{Requisitos legais}

Esses requisitos asseguram o atendimento aos requisitos normativos $\mathrm{e}$ ao alinhamento dos anseios da organização (NETO; TAVARES; HOFFMANN, 2013).

\section{Política de responsabilidade social}

A política contempla as diretrizes da organização perante as questões relacionadas a responsabilidade social (NETO; TAVARES; HOFFMANN, 2013).

\section{Planejamento}

Os requisitos inseridos na fase de planejamento buscam alinhar as ações das organizações para que os requisitos da responsabilidade social sejam alcançados. Os requisitos abordam os seguintes temas: identificação das partes interessadas (alinhamento das necessidades das partes interessadas); temas centrais (governança, 
direitos humanos, práticas de trabalho, meio ambiente, questões relativas ao consumidos, envolvimento e desenvolvimento da comunidade); Due diligence (prevenir e evitar a ocorrência de impacto social negativo); identificação de oportunidades de melhorias e inovação; requisitos legais; objetivos, metas e programas para auxiliar no alcance da responsabilidade social; e recursos, funções, responsabilidade e autoridade (inclui qualificações necessárias, tecnologias, recursos financeiros e humanos e nomeação de responsáveis por repassar o desempenho da responsabilidade social para a alta direção) (NETO; TAVARES; HOFFMANN, 2013).

\section{Implementação e operação}

O conjunto de requisitos que representa a fase "executar" do ciclo PDCA visa assegurar os recursos e condições necessárias para a operação adequada o Sistema de Gestão da Responsabilidade Social. Os requisitos que compõem essa fase abordam as seguintes temáticas: competência, treinamento e conscientização (onde a organização deve estabelecer e manter procedimento para identificar as necessidades de treinamento e conscientização de seus funcionários e de terceirizados) (CERQUEIRA, 2012); engajamento das partes interessadas (estruturação de procedimentos para estabelecer, implementar e engajar as partes interessadas) (NETO; TAVARES; HOFFMANN, 2013); Comunicação (elaborar procedimentos para a comunicação interna e com as partes interessadas externas) (CERQUEIRA, 2012); tratamento de conflitos e desavenças e controle operacional (planejamento das operações associadas aos impactos sociais significativos) (NETO; TAVARES; HOFFMANN, 2013).

\section{Medição, análise e melhoria}

Após o planejamento e a implementação é necessário monitorar e medir os requisitos para identificar se esses estão de em conformidade com os critérios definidos nas fases anteriores. Os temas abordados pelos requisitos inseridos nessa fase são: Monitoramento e medição (permite o acompanhamento do atendimento aos requisitos do sistema de gestão da responsabilidade social); avaliação do atendimento aos requisitos legais e outros (garantir o atendimento legal nos âmbitos federal, estadual e municipal); não conformidade e ações corretivas e preventivas (estruturação de procedimento que identifique não-conformidades reais ou potenciais, ações de mitigação de impactos sociais, análise de causa, entre outros); auditoria interna (identificar internamente a conformidade do Sistema de Gestão da Responsabilidade 
Social); e análise pela direção (análise crítica da alta direção para garantir a adequada continuidade do sistema) (NETO; TAVARES; HOFFMANN, 2013).

De acordo com o estudo realizado por Soratto et al. (2006) que discute a avaliação da conformidade e a certificação de sistema de gestão da responsabilidade social de acordo com a NBR 16001 existem obstáculos potenciais à auditoria de certificação, considerando a subjetividade de seus requisitos e a dificuldade de quantificar objetivos, metas e programas, de acordo com as temáticas propostas.

\subsection{Segurança e saúde ocupacional}

Uma breve contextualização será apresentada para compreender os principais tópicos relacionados a OHSAS 18001 para que posteriormente seja possível correlacionar os requisitos desse padrão normativo com a sustentabilidade corporativa.

\subsubsection{Contextualização}

Preocupações envolvendo saúde e segurança no trabalho podem ser observado em períodos datados antes da aparição de Cristo, no entanto, somente em meados do século XVI surgem as primeiras pesquisas que evidenciaram a possibilidade do trabalho causar danos à saúde dos trabalhadores. Essas investigações ocorreram principalmente na mineração, onde se observou uma doença comum denominada "asma dos mineiros" provocada pelo uso inapropriado do mercúrio causando a intoxicação dos mesmos, além disso, constataram-se elevadas taxas de acidentes nesse ambiente de trabalho (MELO, 2001).

Um marco importante para evolução da história da Segurança e Saúde Ocupacional acorreu com a publicação de uma obra denominada "De Morbis Artificum Diatriba" escrita pelo médico Bernardino Ramazzini. A obra foi pioneira a classificar e sistematizar doenças do trabalho. No entanto, essa e outras pesquisas permaneceram desconhecidas por muito tempo (MELO, 2001).

A partir do século XIX as questões de saúde e trabalho tornou-se preocupação pública especialmente na Inglaterra. A Revolução Industrial levou o trabalhador a se submeter a extensas jornadas de trabalho, conviver com constantes acidentes, precárias condições de trabalho, exposição a trabalhos perigosos e insalubres, além disso, o trabalho infantil era constantemente utilizado nessa época (OLIVEIRA, 2001) (esse fato pode ser observado no livro "O Capital” de Karl Marx publicado 1867). 
Diante desse cenário o Parlamento Inglês em 1802 criou a primeira lei de proteção aos trabalhadores denominada de Lei de Saúde e Moral dos Aprendizes que estabelecia o limite de 12 horas de trabalho por dia, regulamentava o trabalho noturno e tornava obrigatório que as fábricas tivessem ventilação constante e que suas paredes fossem limpas pelo menos duas vezes ao ano. Porém, essa lei não foi eficiente por sofrer grande resistência dos empregadores (MELO, 2001). Posteriormente em 1833 surgiu a lei denominada Factory Act que exigia que as empresas possuíssem escolas que deveriam ser frequentadas por trabalhadores menores de 13 anos, a idade mínima para iniciar o trabalho era apenas 9 anos, além disso, era proibido o trabalho noturno para menores de 18 anos onde poderiam trabalhar no máximo 12 horas por dia (VITORELI, 2010).

Em 1919 foi criado a Organização Internacional do Trabalho (OIT) como parte do Tratado de Versalhes que pôs fim à Primeira Guerra Mundial. A OIT é uma agência responsável por elaborar e aplicar normas internacionais referentes ao trabalho. No ano de sua criação ocorreu a primeira Conferência Internacional do Trabalho organizada pela mesma que adotou seis convenções que são: limitação de 8 horas diárias de trabalho e 48 horas de trabalho semanais, proteção a maternidade, à luta contra o desemprego, à definição da idade mínima de 14 anos para trabalho na indústria e à proibição do trabalho noturno de mulheres e menores de 18 anos (ORGANIZAÇÃO INTERNACIONAL DO TRABALHO, 2015).

No Brasil, o histórico de legislações ocorre com a criação da Confederação Brasileira do Trabalho (CBT), durante o IV Congresso Operário Brasileiro em 1912 que reivindicava questões relacionadas a jornada de trabalho ( 8 horas por dia), indenização para acidentes de trabalho, seguro obrigatório para os casos de doenças, pensão para velhice, fixação de salário mínimo, entre outros (MINISTÉRIO DO TRABALHO E EMPREGO, 2015).

Em 1930 através do Decreto $n^{\circ} 19.433$ foi criado Ministério dos Negócios do Trabalho, Indústria e Comércio que tem como cargo o estudo e despacho de todos os assuntos relativos ao trabalho, indústria e comércio (BRASIL, 1930). O Decreto-Lei $\mathrm{n}^{\circ}$ 5.452 aprova em 1943 a Consolidação das Leis do Trabalho (CLT) que são normas que regulam as relações individuais e coletivas de trabalho (BRASIL, 1943).

Em 1944 o Decreto 7.036 põe em vigor a Lei de Acidentes do Trabalho, onde um dos tópicos abordados era a obrigação das empresas em organizarem comissões internas, com representantes dos trabalhadores, para estimular o interesse na prevenção de acidentes ocupacionais (BRASIL, 1944) (atualmente está lei não está em vigor e foi 
substituída pelo Decreto 7.036 publicado em 2009). Posteriormente em 1953 a Portaria $\mathrm{n}^{\mathrm{o}} 155$ regulamenta a organização e funcionamento das Comissões Internas de Prevenção de Acidentes (CIPA) (MELO, 2001). Em 1966 a Lei no 5.161 autoriza a instituição da Fundação Centro Nacional de Segurança, Higiene e Medicina do Trabalho (FUNDACENTRO) que tem como objetivo a realização de estudos e pesquisas pertinentes aos problemas de segurança, higiene e medicina do trabalho (BRASIL, 1966).

Em 1988 a atual Constituição da Republica Federativa do Brasil foi promulgada e aborda temas como: duração do trabalho normal não superior a oito horas diárias e quarenta e quatro horas semanais, incentivo a inserção das mulheres no ambiente de trabalho, seguro contra a acidentes de trabalho, proibição da distinção entre trabalhos (técnicos, manual e intelectual), proibição do trabalho insalubre; participação sindical, fiscalização do trabalho por órgãos responsáveis, trabalho livre, remuneração, segurodesemprego, redução de riscos que envolvam a saúde e segurança dos trabalhadores, e entre outros (BRASIL, 1988).

O estudo realizado pelo Ministério do Trabalho e Emprego (2015) que estabelece estratégias nacionais para redução dos acidentes do trabalho entre 2015 e 2016 aponta que no Brasil entre o período de 1988 a 2013 ocorreram 14.566.870 doenças e acidentes do trabalho e entre 1996 e 2011 foram notificadas 47.597 mortes relacionadas ao trabalho. Esses acidentes geram custos para a vida e saúde dos trabalhadores, para as famílias, empresas e Estado.

Os custos dos acidentes de trabalho podem ser divididos em três categorias. Os custos diretos que estão incluso gastos com tratamento e reabilitação médica. Os custos indiretos que envolvem custos previdenciários, custos salariais, custos administrativos e perda de produtividade dos trabalhadores quando possível voltar ao trabalho. Os custos humanos estão relacionados com a piora na qualidade de vida do trabalhador e seus familiares (LEBEAU; DUGUAY, 2013). A OIT estima que 2,8 trilhões (4\%) do Produto Interno Mundial (PIB) são perdidos por ano com custos diretos e indiretos relacionados a acidente e doenças do trabalho (INTERNATIONAL LABOUR OFFICE, 2013).

Segundo a Organização internacional do Trabalho (2013a) o melhor caminho para prospecção de um cenário otimista é investir na prevenção que, além de proteger a vida dos trabalhadores e dos meios de subsistência de seus familiares contribui para o desenvolvimento econômico e social dos países. Para isso, é importante a disseminação 
da cultura preventiva de segurança e saúde que exige diálogo entre os trabalhadores, empresários e poder público. O estudo aponta ainda as seguintes necessidades: prevenir, detectar precocemente, tratar e indenizar doenças ocupacionais; integrar a prevenção de doenças e acidentes de trabalho nos programas internos e externos de inspeção do trabalho; implementar medidas preventivas; monitoramento do ambiente de trabalho; vigilância médica; atualizar listas nacionais de doenças profissionais; e reforçar o diálogo entre as partes interessadas.

Aproximadamente 2,02 milhões de pessoas morrem por ano devido a doenças relacionadas ao trabalho (doenças respiratórias, perturbações músculo-esquelética, pneumoconioses, perturbações mentais, entre outras). Observa-se que riscos tradicionais como, por exemplo, a utilização do amianto foi sanada em alguns países que proibiram o uso do mesmo. No entanto, mudanças sociais, tecnológicas e organizacionais nos locais de trabalho decorrentes da globalização trouxeram novos problemas como, por exemplo, estresse e depressão (ORGANIZAÇÃO INTERNACIONAL DO TRABALHO, 2013a).

De acordo com o Manual de Combate ao Trabalho em Condições Análogas às de Escravo desenvolvido pelo Ministério do Trabalho e Emprego (2011) existe diversas denominações relacionadas ao fenômeno de exploração ilícita e precária do trabalho e que são utilizados para tratar indistintamente da mesma realidade jurídica como: trabalho forçado, trabalho escravo, exploração do trabalho, trabalho degradante, semiescravidão, entre outros.

Esse contexto se caracteriza por condições de trabalho que não reúna as mínimas condições necessárias para garantir os direitos dos trabalhadores, restringindo sua liberdade, sujeitando-os a condições degradantes e humilhações que interfiram na dignidade dos mesmos. Condições degradantes se refere a desde o constrangimento físico e/ou moral (ex. impossibilidade do trabalhador extinguir o vínculo de acordo com sua vontade) até péssimas condições de trabalho e remuneração (ex. falta de instalações sanitárias e água potável, higiene e segurança no trabalho, remuneração irregular, jornadas exaustivas de trabalho, alojamentos sem condições de habitações, entre outras condições).

De acordo com o artigo 149, do Código Penal brasileiro existem 4 formas básicas de se caracterizar condições análogas à de escravo que são: a) sujeição da vítima a trabalhos forçados que pode ser definido como "todo trabalho ou serviço exigido de um indivíduo sob ameaça de qualquer penalidade e para o qual ele não se ofereceu de 
espontânea vontade" (ORGANIZAÇÃO INTERNACIONAL DO TRABALHO, 1930); b) sujeição da vítima a jornadas exaustivas que não se refere exclusivamente a duração da jornada de trabalho mas também a esforço excessivos que sobrecarrega o indivíduo; c) sujeição da vítima a condições degradantes; e d) restrição, por qualquer meio, da locomoção da vítima em razão de dívida contraída com o empregado ou preposto (MINISTÉRIO DO TRABALHO E EMPREGO, 2011; BRASIL, 1940).

Com relação a essa temática existem algumas variáveis que devem ser analisadas como: aliciamento de trabalhadores de um local para outro território nacional; violência contra os trabalhadores; restrições à liberdade dos trabalhadores (vigilância armada, localização geográfica, endividamento, ameaças, retenção de documentos e atraso no pagamento de salários); jornada e descanso; identificação das condições de trabalho (equipamento de proteção individual e coletiva, acidentes e doenças, alimentação, agrotóxicos, transporte do trabalhador, ferramentas, máquinas, equipamento, implementos agrícolas e instalações elétricas); tráfico de pessoas e trabalho infantil (MINISTÉRIO DO TRABALHO E EMPREGO, 2011).

O estudo realizado pela Organização Internacional do Trabalho em 2013 que buscou medir o progresso na luta contra o trabalho infantil mundial e mapeou esse cenário indica que 168 milhões de crianças trabalham em todo o mundo correspondendo a $11 \%$ da totalidade da população infantil mundial e que 85 milhões de crianças executam trabalho perigoso que colocam em risco suas vidas, segurança e desenvolvimento moral. De acordo com dados coletados em 2008 o número de crianças trabalhando perigosamente era de aproximadamente 115 milhões, sendo assim, observou-se uma diminuição no número de crianças trabalhando perigosamente (ORGANIZAÇÃO INTERNACIONAL DO TRABALHO, 2013b).

Pode-se definir que trabalho infantil "é aquele realizado por crianças e adolescentes que estão abaixo da idade mínima para a entrada no mercado de trabalho, segundo a legislação em vigor no país" (ORGANIZAÇÃO INTERNACIONAL DO TRABALHO, 2001). No Brasil é proibido que crianças menores de 16 anos trabalhem, salvo nas condições de aprendiz, a partir dos 14 anos conforme a Lei 10.097/2000, art. $1^{\circ}$ (BRASIL, 2000).

Diante desse contexto, de acordo com a Declaração Relativa aos Direitos e Princípios Fundamentais no Trabalho (1998) trabalho descente está relacionado a intersecção de quatro objetivos estratégicos que são: a) liberdade sindical e reconhecimento efetivo do direito de negociação efetiva; b) eliminação de todas as 
formas de trabalho forçado; c) abolição efetiva do trabalho infantil; e d) eliminação de todas as formas de discriminação em matéria de emprego e ocupação (inclusive com relação a inserção das mulheres no mercado de trabalho) (ORGANIZAÇÃO INTERNACIONAL DO TRABALHO, 1998).

A ideia de que as mulheres geram mais custos se comparado aos homens é observado frequentemente no ambiente corporativo. Esse fato constituiu uma importante barreira para o acesso das mulheres em melhores empregos e igualdade salarial. Os principais fatores que estão relacionados a essa ideia são: que as mulheres são menos produtivas se comparados aos homens, alto número de absenteísmo, resistência em fazer horas extras e viagens (cuidados com a família), perdas financeira e de produção no período de gestação e custos indiretos relacionados a maternidade e cuidados infantil (ORGANIZAÇÃO INTERNCIAONAL DO TRABALHO, 2005).

Um estudo realizado pela Organização Internacional do Trabalho em 2001 que pesquisou sobre o custo do trabalho de homens e mulheres em cinco países da América Latina (Argentina, Brasil, Chile, México e Uruguai). Para obtenção dos resultados foi aplicado um questionário para as empresas selecionadas. As principais perguntas do questionaram foram: a) Os custos não-salariais do trabalho das mulheres assalariadas são mais altos que os dos homens, e, em caso afirmativo, isso constituiria um desestímulo para a sua contratação, ou para que elas tenham acesso a condições igualitárias de trabalho em comparação com os homens? b) O absenteísmo das mulheres é ou não mais elevado que o dos homens e, em caso afirmativo, constitui um desestímulo para a sua contratação? c) Qual é o custo da reprodução biológica e social, e de que maneira esse custo incide sobre o trabalho? d) Quem assume e quem deve assumir esse custo: as mulheres, as famílias, as empresas, o conjunto da sociedade? (ORGANIZAÇÃO INTERNACIONAL DO TRABALHO, 2005).

Diante desse contexto, o estudo a cima concluiu que o custo não-salarial associados diretamente à maternidade e aos cuidados infantil representam menos de $2 \%$ da remuneração bruta mensal das mulheres assalariadas nos 5 países estudados; com relação ao período de licença-maternidade a empresa não tem custos, pois o pagamento do salário das mulheres nessas condições não é assumido pela empresa e sim pela previdência social, sendo assim, a maternidade não deve ser abordado como um problema; os salários das mulheres são inferiores aos dos homens pois assumem gastos que na realidade não existe como os citado anteriormente; e o absenteísmo das mulheres 
descartando o período de licença-maternidade é praticamente igual ao dos homens (ORGANIZAÇÃO INTERNACIONAL DO TRABALHO, 2005).

Diante dessa contextualização, nas décadas de 1980 e 1990 foram desenvolvidos alguns modelos normativos que auxiliam as empresas a gerirem a segurança e saúde ocupacional como, por exemplo, a BS 8800:1996 que estabelece diretrizes e orientações para a estruturação do sistema de gestão. Posteriormente, com aceitação de normas de sistema de gestão da qualidade e ambiental observou-se uma demanda por um padrão normativo que estivesse características similares as normas ISO 9001 e ISO 14001. Diante desse contexto em 1999 foi publicada a Ocucupational Health and Safety Assessment Series (OSHAS) (NETO; TAVARES; HOFFMANN, 2013).

\subsubsection{Sistema de gestão de segurança e saúde ocupacional - OHSAS 18001: 2007}

O sistema de gestão de segurança e saúde permite que organizações implementem práticas de segurança e gerenciamento de riscos, desde de que esse sistema esteja estruturado e integrado com todas as atividades da empresa. O gerenciamento de riscos corporativos visa proporcionar maneiras de identificar, combater e mitigar riscos que envolvem todos os trabalhadores de uma organização (MUÑIZ; PEÓN E ORDÁS, 2012).

Para que o sistema de segurança e saúde alcance seu objetivo é necessário que todos os funcionários desde a alta administração até cargos hierarquicamente inferiores estejam cientes da importância de gerenciar risco e comprometam-se em gerenciar os riscos em seus postos de trabalho (MUÑIZ; PEÓN E ORDÁS, 2012).

O objetivo da OHSAS 18001:2007 é estabelecer um sistema de gestão da Segurança e Saúde do Trabalho (SST) destinado a eliminar ou minimizar o risco para os trabalhadores e outras partes interessadas que possam ser expostas a riscos para a SST associados às suas atividades (BRITISH STANDARDS INSTITUTION, 2007).

Esse padrão normativo foi criado por diversos organismos certificadores e entidades nacionais de normalização. Nesta época a ISO não assumiu a responsabilidade de elaborar essa norma, pois entendia a existência de algum grau de superposição com as atividades desenvolvidas pela Organização Internacional do Trabalho (OIT). No entanto, em 2013 a ISO criou o comitê ISO/PC 283 que deu início a elaboração de uma norma internacional que deverá substituir a OHSAS 18001:2007. A publicação está prevista para 2016 (NETO; TAVARES; HOFFMANN, 2013). 
Desde sua criação a OHSAS 18001 apresentou uma aceitação das empresas do mundo inteiro, talvez pelo fato dessa norma ser facilmente integrada com a ISO $9001 \mathrm{e}$ 14001 e por ser um padrão certificável (SEIFFERT, 2010). No Brasil, de acordo com o Anuário Brasileiro de Proteção de 2013, até o final de dezembro de 2012 cerca de 846 empresas obtiveram o certificado OHSAS 18001 (REVISTA PROTEÇÃO, 2014).

Em 2007, a OHSAS teve sua primeira revisão que trouxe mudanças como: uma maior ênfase na importância da saúde, prevenção e gerenciamento de incidentes, além de um melhor alinhamento com a ISO 14001:2004 (NETO; TAVARES; HOFFMANN, 2013). A norma foi desenvolvida com base no ciclo PDCA (Plan, Do, Check e Act), sendo que os requisitos da norma podem ser relacionados com cada uma das etapas do ciclo, como mostra o quadro 6.

\begin{tabular}{|c|c|c|}
\hline Cláusula & & Título do requisito \\
\hline 4.1 & & Requisitos gerais. \\
\hline 4.2 & & Política de SST. \\
\hline \multirow{3}{*}{4.3} & \multirow{3}{*}{ Planejamento } & $\begin{array}{l}\text { 4.3.1 Identificação de perigos, avaliação de riscos e determinação } \\
\text { de medidas de controle. }\end{array}$ \\
\hline & & 4.3.2 Requisitos legais e outros requisitos. \\
\hline & & 4.3.3 Objetivos e programa(s). \\
\hline \multirow{7}{*}{4.4} & \multirow{7}{*}{$\begin{array}{l}\text { Implementação e } \\
\text { operação }\end{array}$} & $\begin{array}{l}\text { 4.4.1 Recursos, atribuições, responsabilidade, obrigações e } \\
\text { autoridades. }\end{array}$ \\
\hline & & 4.4.2 Competência, formação e sensibilização. \\
\hline & & 4.4.3 Comunicação, participação e consulta. \\
\hline & & 4.4.4 Documentação. \\
\hline & & 4.4.5 Controle dos documentos. \\
\hline & & 4.4.6 Controle operacional. \\
\hline & & 4.4.7 Preparação e resposta a emergências. \\
\hline \multirow{5}{*}{4.5} & \multirow{5}{*}{ Verificação } & 4.5.1 Medição e monitoramento do desempenho. \\
\hline & & 4.5.2 Avaliação da conformidade. \\
\hline & & $\begin{array}{l}\text { 4.5.3 Investigação de incidentes, não conformidades, ações } \\
\text { corretivas e ações preventivas. }\end{array}$ \\
\hline & & 4.5.4 Controle dos registros. \\
\hline & & 4.5.5 Auditoria interna. \\
\hline 4.6 & & Revisão pela Gestão. \\
\hline
\end{tabular}

Quadro 6. Estrutura da norma OHSAS 18001:2007 (BRITISH STANDARDS INSTITUTION, 2007).

\section{Requisitos gerais}

Esta subseção aponta diretrizes para uma organização que anseia implementar um Sistema de Segurança e Saúde no Trabalho (SST) em conformidade com a OHSAS 18001:2007 (KAUSEK, 2007). Esse requisito estabelece a obrigatoriedade do 
cumprimento dos demais requisitos descritos na norma (NETO; TAVARES; HOFFMANN, 2013).

\section{$>$ Política da segurança e saúde no trabalho}

Esta subseção aponta a necessidade de elaboração de uma política de SST e o comprometimento da Alta Direção em atendê-la. Essa política deve apresentar de forma clara as intenções da organização a respeito da SST (KAUSEK, 2007).

\section{$>$ Planejamento}

Segundo Neto, Tavares e Hoffmann (2013) os requisitos inseridos na fase de planejamento tem como objetivo estabelecer um alinhamento das ações das organizações. Os autores apontam a necessidade de identificar os perigos e requisitos legais, posteriormente o estabelecimento de objetivos de SST e programas que auxiliem no atendimento dos objetivos.

\section{$>$ Implementação e operação}

Os requisitos inseridos nessa fase apontam assuntos como: identificação de recursos necessários para implementar e manter o SST; definição responsabilidade e funções onde os responsáveis deverão prestar contas a alta direção; competência, treinamento e conscientização de todos os funcionários que poderiam sofrem impactos relacionados a SST; comunicação e consulta (a organização deve estabelecer um procedimento para a comunicação interna e/ou externa de aspectos relacionados a SST); documentação (criação de um manual de SST); controle de documentos (envolve revisão de documentos, documentar procedimentos, remover documentos obsoletos e localização de documentos quando necessário); controle operacional (consiste no controle de todos os métodos necessários para o controle da SST organizacional e identificação de riscos durante essa fase); e preparação a resposta a emergência (a organização deve identificar potencial acidentes ou situações de emergência e elaborar procedimentos para a a prevenção e/ou mitigação de possíveis impactos negatrivos a SST) (KAUSEK, 2007).

Esse conjunto de requisitos visa assegurar os recursos e condições necessárias para a operação adequada o Sistema de Gestão da Segurança e Saúde no Trabalho (SGSST). Para uma correta implementação e funcionamento de um SGSST o 
planejamento levará ao estabelecimento de práticas de prevenção e controle (NETO; TAVARES; HOFFMANN, 2013).

\section{$>$ Verificação}

Após o planejamento e a implementação é necessário monitorar e medir os requisitos para identificar se esses estão de em conformidade com os critérios definidos nas fases anteriores (NETO; TAVARES; HOFFMANN, 2013). Os temas abordados pelos requisitos inseridos nessa fase são: monitoramento e medição (a organização estabelece controle operacional para minimizar os perigos no ambiente de trabalho); acidentes, incidentes, não-conformidade, ação corretiva e preventiva; controle de registros (proteção dos documentos de deteriorização, perda, retenção, entre outros perigos); e auditoria interna que garante a melhoria contínua do SGSST (KAUSEK, 2007).

\section{Análise crítica pela direção}

Esta etapa representa o ciclo final do PDCA onde se analisa os compromissos estabelecidos na política e nos objetivos estão sendo atendidos (NETO; TAVARES; HOFFMANN, 2013). A alta direção deve periodicamente realizar essa fase para garantir a sustentabilidade, eficiência e adequação do SGSST (KAUSEK, 2007).

No estudo realizado por Fernández-Muñiz; Montes-Peón e Vázquez-Ordás (2009) que teve como objetivo identificar boas práticas na gestão da segurança e analisar o efeito dessas práticas sobre um conjunto de indicadores de desempenho organizacional (ex. lesões pessoais, danos materiais, motivação dos colaboradores, satisfação do cliente, produtividade, qualidade do produto, entre outros). A amostra do estudo foi composta de 455 empresas espanholas nas quais foi testado o modelo elaborado pelo autor. Diante desse contexto, o autor concluiu que a implementação de um sistema de gestão da segurança e saúde do trabalho pode reduzir as taxas de acidentes, lesões pessoais, melhora as condições de trabalho, aumenta a motivação dos funcionários, reduz o absenteísmo, melhora da imagem e reputação empresarial, influência positiva na produtividade e inovação e influência positiva sobre vendas, lucros e rentabilidade da empresa.

A OHSAS 18001:2007 está passando atualmente (julho/2015) pelo processo de revisão. Essa norma será substituída pela ISO 45001:2016 (THE BRITISH 
STANDARDS INSTITUTION, 2015). As principais mudanças que ocorrerão estão relacionadas a inserção dos aspectos de segurança e saúde ocupacional no sistema de gestão global da organização deixando de ser apenas aspectos extras, aumento do comprometimento da alta direção e de lideranças, maior ênfase na gestão de riscos, ênfase na necessidade de entender e demonstrar conformidade, entre outras (INTERNATIONAL STANDARDS ORGANIZATION, 2015).

\subsection{Sustentabilidade empresarial}

Uma breve contextualização será apresentada para compreender os principais tópicos relacionados a sustentabilidade corporativa para que posteriormente seja possível relacionar a sustentabilidade empresarial com as normas ISO 9001, ISO 14001, OHSAS 18001 e NBR 16001.

\subsubsection{Contextualização}

A sustentabilidade empresarial é um tema que vem sendo discutido gradativamente com o passar do tempo. No entanto, observa-se que existe pouco conhecimento de como as práticas de sustentabilidade poderiam ajudar efetivamente as empresas (LINNENLUECKE; GRIFFITHS, 2010).

Para Elkington (2001) sustentabilidade é "o princípio de assegurar que nossas ações de hoje não limitarão a gama de opções econômicas, sociais e ambientais disponíveis para as gerações futuras”. Segundo Van Marrewijk (2003) sustentabilidade corporativa é "o que demonstra a inclusão de preocupações sociais e ambientais nas operações comerciais e nas interações com as partes interessadas".

Para Jappur (2004) sustentabilidade corporativa está ligada ao compromisso que a empresa possui perante o assunto. Ou seja, "entre seus objetivos, o cuidado com o meio ambiente, o bem-estar das partes interessadas e a constante melhoria da sua própria reputação".

Sustentabilidade corporativa pode ser considerada como "a adoção de estratégias de negócios e atividades que atendam as necessidades da empresa e seus stakeholders, protegendo, mantendo e melhorando os recursos naturais que serão necessários no futuro humano" (INTERNATIONAL INSTITUTE FOR SUSTAINABLE DEVELOPMENT, 1992).

As empresas podem ainda considerar os aspectos sociais, éticos e ambientais na tomada de decisão apenas se essa integração propiciar retornos financeiros, ou seja, 
consideram esses aspectos para obterem vantagens financeiras (MARREWIJK, 2003). Na visão de Savitz e Weber (2007), uma empresa sustentável é aquela que gera lucro para os acionistas, ao mesmo tempo em que protege o meio ambiente e melhora a vida das pessoas com quem mantém interações.

Wagner (2005) realizou um estudo que discute as influências das estratégias corporativas (fim de tubo e prevenção da poluição) no desempenho econômico e ambiental das organizações. $\mathrm{O}$ autor constatou que empresas que adotaram estratégias ambientais orientadas para a preservação obtiveram uma relação positiva entre desempenho econômico e ambiental. Em contra partida aquelas que levaram em consideração apenas o tratamento fim de tudo tiveram efeitos negativos do desempenho ambiental se comparado ao desempenho econômico.

Ainda os autores Hart (1997), Reinhardt (1999), King e Lenox (2001) e Wagner (2010) demonstraram em seus estudos que empresas que consideram as questões ambientais em seu desenvolvimento estratégico possuem um desempenho financeiro superior se comparado a outras que não demonstraram esse interesse provando que as organizações podem ser "verdes" e ao mesmo tempo competitivas. Por exemplo, o estudo realizado por Dowell; Hart e Yeung (2000) apontou que empresas que adotaram normas globais ambientais tiveram retorno financeiro superior das demais.

Sendo assim, as organizações poderiam guiar o crescimento econômico aliado ao social e ambiental para alcançar sucesso em longo prazo. No entanto as organizações estão focadas em ganhos de curto prazo impulsionadas principalmente pelo mercado de ações. Ainda, as taxas de desconto tendem a valorizar esse tipo de ganho tornando os custos associados à responsabilidade social e ambiental não atraentes (DYLLICK; HOCKERTS, 2002).

As empresas que tiverem como meta obter ganhos de longo prazo considerando o tripé da sustentabilidade estarão propicias a alcançar a sustentabilidade corporativa (DYLLICK; HOCKERTS, 2002). Diante desse contexto, Bos-Brouwers (2010) afirma que as organizações consideram a inovação como um dos principais processos de garantia de rentabilidade em longo prazo. Com o aumento da pressão das partes interessadas as empresas estão preocupadas em eliminar os impasses ambientais e sociais utilizando a inovação sustentável para reverter o cenário mundial.

Segundo Bos-Brouwers (2010) inovação sustentável pode ser definida como a renovação ou melhoria de produtos, serviços e processos que proporcionam desempenho econômico, social e ambiental. Além disso, afirma que sustentabilidade 
corporativa visa melhorar o desempenho ambiental, econômico e social de empresas baseando-se no tripé da sustentabilidade.

Marrewijk (2003) em seu trabalho interpretou várias definições de sustentabilidade corporativa considerando o nível de ambição das corporações. Para o autor sustentabilidade corporativa pode ser orientada pelo compromisso das empresas em proporcionar o bem-estar da sociedade, sendo percebida como um dever e obrigação na busca de um comportamento correto.

A sustentabilidade corporativa pode ser adotada também como uma iniciativa das empresas em ir além do atendimento as conformidades legais e obtenção de lucro. Consiste na busca de soluções equilibradas entre as esferas econômicas, sociais e ecológicas havendo uma sinergia entre as partes interessadas, além disso, é reconhecida como um progresso na busca por melhores condições de vida (MARREWIJK, 2003).

$\mathrm{O}$ autor ainda afirma que a sustentabilidade corporativa pode ser "totalmente integrada e incorporada em todos os aspectos da organização, visando contribuir para a qualidade e continuidade da vida de cada entidade e ser no presente e futuro" (MARREWIJK, 2003). O autor ressalta que nessa abordagem a sociedade é responsável pela manutenção de todos os seres vivos do planeta. Diante desse contexto, as empresas são consideradas integrantes da sociedade, ou seja, cabendo a elas não somente oferecer produtos de qualidade como também auxiliar na preservação e/ou mitigação dos aspectos ambientais e sociais (PIMENTA, 2010).

Segundo Dyllick e Hockerts (2002) empresas ecologicamente sustentáveis consomem os recursos naturais de maneira consciente, não se envolvem em atividade que degradem o meio ambiente e não emitem gases que se acumulam no ambiente a uma taxa superior à capacidade do sistema natural de absorver e assimilar essas emissões, ou seja, respeitam a capacidade de suporte do planeta.

Os autores em seu estudo apontaram os principais aspectos ambientais que devem ser considerados pelas empresas para o alcance da sustentabilidade corporativa sendo eles: as emissões de gases para o ar, lançamento de efluentes na água, emissão de poluentes no solo, descarte de resíduos, biodiversidade e questões relacionadas ao produto (utilização de material biodegradável, eliminação de substâncias tóxicas, considerar o ciclo de vida do produto, remanufatura, ecodesign, entre outros) (BAUMGARTNER; EBNER, 2010).

Amaral (2005) argumenta que a sustentabilidade corporativa considerando os pilares ambientais e sociais será alcançada através da Ecoeficiência (entrega de produtos 
e serviços com qualidade e que não impacte o meio ambiente) e Responsabilidade Social (comprometimento da empresa em promover a qualidade de vida, igualdade social, entre outros princípios éticos).

Segundo Dyllick e Hockerts (2002) sustentabilidade corporativa pode ser definida como a responsabilidade que as empresas possuem em atender as necessidades diretas e indiretas das partes interessadas (acionistas, colaboradores, clientes, sociedade civil, entre outros) sem comprometer a capacidade de atender as necessidades das futuras gerações.

Ainda segundo Dyllick e Hockerts (2002) existem dois tipos de capital envolvendo as partes interessadas. O capital humano que está relacionado a aspectos como habilidades, motivação, criação de parcerias e fidelização dos funcionários e o capital social que inclui a qualidade de serviços públicos (educação, saúde, empregos, cultura, entre outros). Para os autores empresas socialmente sustentáveis valorizam as comunidades em que operam promovendo capital social considerando todos os stakeholders e aumenta o capital humano e de seus parceiros.

Os aspectos sociais apontados pelos autores Baumgartner e Ebner (2010) são fundamentais para o alcance da sustentabilidade em uma organização são eles: envolver governança corporativa transparente para melhorar o relacionamento entre os stakeholders, motivação e incentivo, garantia da segurança e saúde no trabalho, desenvolvimento do capital humano através da orientação, treinamento e educação permanente, comportamento ético e garantia dos direitos humanos, sem corrupção, formação de cartéis e praticar a cidadania empresarial

Diante das discussões apresentadas anteriormente observa-se que empresas que desejam tornar-se sustentáveis na maioria das vezes necessitam realizar mudanças culturais para garantir que todas as partes interessadas estejam envolvidas. Sendo assim, os autores Linnenluecke e Griffiths (2010) observaram uma inexistência de literatura consolidada apontando como a cultura organizacional orientada para a sustentabilidade corporativa é composta. Diante desse contexto, os autores identificaram que essa cultura pode ser composta por diversas sub-culturas, sendo que cada membro pode conter atitudes distintas se comparadas com outras sub-culturas. Por exemplo, funcionários de diferentes sub-culturas podem dar ênfase ao desenvolvimento pessoal interno, eficiência de recursos, proteção ao meio ambiente ou engajamento dos stakeholders.

Observou-se que a maioria dos conceitos de sustentabilidade corporativa são vagos. Os autores Marrewijk e Werre (2003) afirmam que cada organização deve 
escolher ou desenvolver seu próprio conceito de sustentabilidade corporativa considerando seu contexto.

\subsubsection{As dimensões/pilares da sustentabilidade}

Em 1983 foi criado a Comissão Mundial sobre o Meio Ambiente e o Desenvolvimento (CMMAD/WCED) que formulou e direcionou propostas para solucionar as questões ambientais críticas. Em 1987 essa comissão apresentou para o mundo o Relatório de Brundtland ou também conhecido como "Nosso Futuro Comum" o qual formalizou o conceito de desenvolvimento sustentável que é definido como "o desenvolvimento que satisfaz as necessidades do presente sem comprometer a capacidade das gerações futuras satisfazerem as suas próprias necessidades" ambiente. No Relatório "Nosso Futuro Comum" são apresentados três componentes fundamentais para o desenvolvimento sustentável que envolve a proteção ambiental, crescimento econômico e equidade social (ORGANIZAÇÃO DAS NAÇÕES UNIDAS, 2014b).

Através destes três componentes surge o conceito desenvolvido por Elkington denominado por triple bottom line, que são basicamente três pilares (social, econômico e ambiental) que norteiam as decisões organizacionais a fim de aproximar os conceitos de responsabilidade social corporativa ao desenvolvimento sustentável. A seguir os pilares do triple bottom line serão apresentados (ELKINGTON, 2001).

Pilar social: O autor afirma que o grau de confiança entre as organizações a seus stakeholders é um fator importante no alcance da sustentabilidade em longo prazo. Além disso, os custos sociais precisarão ser inseridos na contabilidade. A contabilidade social "tem o objetivo de avaliar os impactos de uma organização ou empresa sobre as pessoas (interna e externa)". Questões como treinamento e educação, relação com a comunidade de entorno, segurança no trabalho e do produto, geração de empregos para minorias e filantropia estão sendo incorporados nos custos sociais. A entrelinha que envolve os pilares econômico e social coloca em pauta questões como a ética empresarial, desemprego e direito de minorias;

Pilar econômico: O pilar de uma empresa é o lucro. Para calcula-lo os contadores levantam, registram e analisam dados numéricos. No contexto da sustentabilidade existe uma necessidade das empresas elaborem um modelo de contabilidade que insira a contabilidade ambiental e social. Para isso é 
necessário entender que capital econômico significa o valor total de seus ativos menos as suas obrigações. O capital de uma empresa é composto por capital físico (ex. maquinários), capital financeiro, capital humano e capital intelectual, além disso, o capital natural e social precisarão serem absorvidos pelo capital econômico, onde todas as externalidades deverão ser internalizadas. Nas entrelinhas entre os pilares econômico e ambiental está a eco-eficiência que envolve bens e serviços que eliminaram ou minimizaram os impactos ambientais em seus processos de produção e que possuam qualidade e competividade no mercado; e

Pilar ambiental: Nesse pilar o autor aponta a necessidade de se contabilizar as riquezas naturais como madeira, água, solo, fauna, flora, biodiversidade, emissão de gases como o dióxido de carbono e o metano na atmosfera (proveniente do consumo de recursos não-renováveis), utilização de recursos renováveis entre outras riquezas que sustentam um ecossistema. Ou seja, as organizações deverão certificar-se de que não estão ultrapassando a capacidade de suporte do planeta. Uma das formas de alcançar esse objetivo é monitorando os seus impactos ambientais e de seus fornecedores, ou ainda em toda a cadeia produtiva considerando o ciclo de vida dos produtos. Nas entrelinhas entre os pilares ambiental e social existem as questões relacionadas às injustiças ambientais, onde pessoas ficam em desvantagem em razão de problemas ambientais.

Inserido no contexto da Rio 92 o autor Sachs (1993) afirma que para planejar o desenvolvimento é necessário considerar cinco dimensões da sustentabilidade que serão apresentadas a seguir:

Sustentabilidade social: na qual o objetivo é construir uma civilização com maior equidade na distribuição de renda para que a distância entre os privilegiados diminua em relação aos desprivilegiados, além disso, garantia de melhores condições de vida e cumprimento dos direitos de cada cidadão;

> Sustentabilidade econômica: busca alocar e gerir os recursos de maneira eficiente, onde são avaliados termos macro-sociais e não somente lucratividade empresarial;

Sustentabilidade ecológica: que aponta as necessidade de diminuir a utilização de recursos não-renováveis substituindo-os por recursos ou 
produtos renováveis e/ou abundantes e ambientalmente inofensivos, redução da geração de resíduo e da poluição, investimento em ciência e tecnologias limpas e cumprimento das legislações vigentes em cada país;

Sustentabilidade espacial: defende a ideia de uma relação equilibrada entre a configuração rural e urbana, onde ocorra uma melhor distribuição de terras e assentamentos humanos e atividades econômicas que enfatizem as seguintes questões: concentração excessiva de áreas metropolitanas, incentivo a pequenos agricultores, estabelecimento de áreas de reservas naturais, entre outros;

$>$ Sustentabilidade cultural: defende a ideia do respeito as especificidades de cada ecossistema, de cada cultura e de cada local.

Posteriormente o autor inseriu outra dimensão que é a sustentabilidade política (SACHS, 2002).

Sustentabilidade política: no âmbito nacional baseia-se na democracia, garantia dos direitos humanos e desenvolvimento de projetos sociais. No âmbito internacional baseia-se na prevenção de guerras, na paz mundial, na cooperação entre as confederações, nas questões ambientais, na preservação da biodiversidade e da diversidade cultural e cooperação cientifica e tecnológica.

No Brasil o Instituto Brasileiro de Geografia e Estatística (IBGE) publicou indicadores de desenvolvimento sustentável como uma forma de integrar-se ao conjunto de esforços internacionais considerando os princípios firmados na Rio 92. O intuito da publicação foi de divulgar a população a realidade brasileira frente ao desenvolvimento sustentável. A publicação aponta indicadores relacionados a dimensão ambiental que abordam temas como: atmosfera, terra, água doce, oceanos, mares e áreas costeiras, biodiversidade e saneamento. A dimensão social aponta indicadores relacionados a população, trabalho e rendimento, saúde, educação, habitação, segurança, situação social, distribuição de renda e condições de vida da população. A dimensão econômica trata de indicadores de desempenho macroeconômico e financeiro, além dos impactos no consumo de recursos materiais e uso de energia primária. A dimensão institucional aponta indicadores relacionados a orientação política, capacidade e esforços necessárias 
para a melhora nos resultados dos indicadores (INSTITUTO BRASILEIRO DE GEOGRAFIA E ESTATÍSTICA, 2004).

Diante desse contexto, esses pilares e dimensões surgem como uma forma de minimizar a desigualdade social e econômica nos países e incentivar a conscientização a respeito das questões ambientais.

\subsubsection{Colocando em prática}

As organizações estão adotando ferramentas que as auxiliam a atingirem a sustentabilidade corporativa como, por exemplo, os Indicadores Ethos, o Índice de Sustentabilidade Corporativa e o Global Reporting Initiative (GRI).

Os indicadores Ethos para negócios sustentáveis e responsáveis são ferramentas que auxiliam as empresas a incorporarem na sua gestão os conceitos relacionados à sustentabilidade corporativa (Ethos, 2007). A ferramenta é composta por um questionário onde é possível as empresas realizarem um autodiagnóstico da gestão e identificar em qual nível a empresa está inserida facilitando a incorporação dos conceitos que permeiam a sustentabilidade corporativa (Ethos, 2014). Os indicadores abordam tema sete temas principais são eles: valores, transparência e governança, público interno, meio ambiente, fornecedores, consumidores e clientes, comunidade, governo e sociedade (Ethos, 2007). Segundo Silveira, 2008 a principal finalidade desses indicadores são auxiliar no processo de incorporação e monitoramento de práticas de gestão relacionadas à responsabilidade social.

O Índice de Sustentabilidade Empresarial é "uma ferramenta para análise comparativa do desempenho das empresas listadas na BM\&FBovespa sob o aspecto da sustentabilidade corporativa, baseada em eficiência econômica, equilíbrio ambiental, justiça social e governança corporativa" (BOVESPA, 2014).

Sua missão é “induzir as empresas a adotarem as melhores práticas de sustentabilidade empresarial e apoiar os investidores na tomada de decisão de investimentos socialmente responsáveis”. Os questionários são divididos em dimensão ambiental (questionário especifico para cada setor de atuação), dimensão mudanças climáticas, dimensão natureza do produto, dimensão econômica, dimensão governança corporativa, dimensão social e dimensão geral (BOVESPA, 2014).

Outra ferramenta utilizada pelas empresas para demonstrarem seu desempenho sustentável é o Global Reporting Initiative (GRI). O GRI "auxilia as organizações a estabelecer metas, aferir seu desempenho e gerir mudanças com vistas a tornar suas 
operações mais sustentáveis", divulgando informações de seus impactos econômico e socioambientais (GLOBAL REPORTING INITIATIVE, 2013). O GRI tem como objetivo "ajudar relatores a elaborar relatórios de sustentabilidade relevantes, que incluam informações valiosas sobre as questões de sustentabilidade mais cruciais para a organização, bem como tornar o processo de relato de sustentabilidade uma prática padrão" (GLOBAL REPORTING INITIATIVE, 2013).

Essa ferramenta traz o conceito de "materialidade" que significa "que os relatórios de sustentabilidade focarão questões efetivamente cruciais para a consecução das suas metas e gestão do seu impacto na sociedade", tornando-os mais confiáveis e compreensíveis (GLOBAL REPORTING INITIATIVE, 2013).

Diante desse contexto, os Indicadores Ethos, o Índice de Sustentabilidade Empresarial e o GRI apontam indicadores essenciais que podem ser utilizados por empresas que desejam alcançar um maior nível de maturidade referente a sustentabilidade. Sendo assim, esses documentos serviram de base para identificação dos principais requisitos da sustentabilidade apontados nesse estudo (Apêndice 1).

\subsection{Consolidação dos conceitos}

A sustentabilidade é um princípio que vem sendo discutido por muitos pesquisadores e que está sendo incorporado por diversas organizações como uma forma de minimizar os impactos ambientais, sociais e econômicos causados pelos processos produtivos. Neste trabalho adotou-se o conceito de sustentabilidade proposto por Elkington (2001) que consiste no "princípio de assegurar que nossas ações de hoje não limitarão a gama de opções econômicas, sociais e ambientais disponíveis para as gerações futuras".

Diante desse contexto, empresas do mundo inteiro estão deixando de considerar somente questões econômicas e passaram a atentar-se as questões socioambientais. Essas mudanças de pensamento estão diretamente relacionadas com as pressões que as partes interessadas estão impondo. Sendo assim, as organizações utilizam ferramentas como normas de sistema de gestão ISO 14001, ISO 9001, OHSAS 18001 e NBR 16001 para auxiliar a satisfazer os anseios das partes interessadas e tornarem-se sustentáveis.

De acordo com a revisão bibliográfica identificou-se estudos que apontam as vantagens, os benefícios, as barreiras e o desempenho econômico, social ou ambiental que a implementação desses sistemas podem trazer para as empresas. No entanto, não se identificou estudos que correlacionassem esses padrões normativos com a 
sustentabilidade corporativa. Sendo assim, partiu-se do pressuposto que a norma ISO 14001 representa o pilar ambiental, a ISO 9001 representa apenas um elemento que compõe o pilar econômico, a NBR 16001 representa o pilar social e a OHSAS 18001 representa um dos elementos do pilar social considerando o modelo do "triple bottom line".

Além disso, a sustentabilidade pode ser medida nas organizações através da utilização de indicadores de sustentabilidade como descritos no Índice de Sustentabilidade Empresarial, nos Indicadores Ethos e no Global Reporting Initiative. Sendo assim, os principais requisitos da sustentabilidade foram coletados desses documentos. Diante desse contexto, esse estudo busca identificar a relação entre as normas de sistema de gestão e os requisitos da sustentabilidade extraído desses documentos. 


\section{Tapítula 3}

\section{MÉTODO DE DESENVOLVIMENTO DA PESQUISA}

Esta sessão ilustrará os passos realizados para a elaboração da Matriz de Relação. Esse instrumento auxiliou na identificação da relação existente entre as normas de sistema de gestão (ISO 9001, ISO 14001, OHSAS 18001 e NBR 16001) e a sustentabilidade empresarial. As etapas foram as seguintes: realização de uma revisão bibliográfica exploratória para identificação dos requisitos da sustentabilidade empresarial; leitura e interpretação das normas de sistema de gestão utilizadas; construção da Matriz de Relação Teórica; preenchimento da Matriz de Relação Teórica; consulta com especialistas; compilação das opiniões dos especialistas e criação da Matriz de Relação Consolidada como mostra a figura 6.

\section{Etapas de desenvolvimento da Matriz de Correlação}

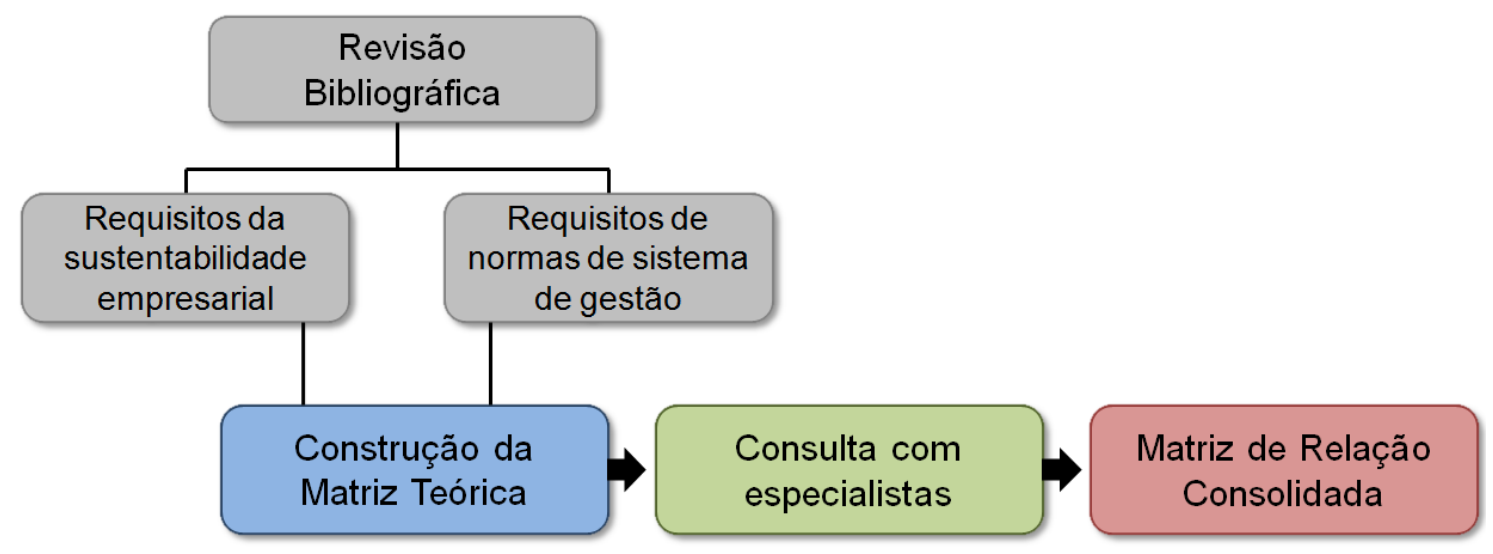

Figura 6. Método de desenvolvimento da Matriz de Relacionamento (Elaborado pela autora).

\subsection{Etapa 1 - Seleção das normas de sistema de gestão}

A seleção das normas de sistema de gestão utilizadas no estudo foi a primeira etapa para a construção da Matriz de Relação Teórica. Os critérios de seleção das normas foram:

$>$ Normas de sistema de gestão conhecidas mundialmente;

$>$ Normas de sistema de gestão que se enquadram nas dimensões da sustentabilidade de acordo com a teoria do Triple bottom line (ambiental, social, econômico e suas inter-relações); 
Normas que sejam passiveis de certificação.

A escolha foi baseada na Coletânea divulgada pela ABNT em 2012 que indica normas que auxiliam no suporte a sustentabilidade corporativa. Sendo assim, a ISO 14001, ISO 9001 e OHSAS 18001 foram escolhidas, pois atendem todos os requisitos de inclusão. A NBR 16001 não é um padrão mundialmente conhecido, já que se aplica apenas ao cenário brasileiro, mas essa norma foi considerada, pois assemelha-se em alguns aspectos com a norma ISO 26000 que estabelece diretrizes para implementação de um sistema de responsabilidade social. Os aspectos semelhantes são: os princípios da transparência, comportamento ético, respeito pelas partes interessadas, respeito pelas normas internacionais de comportamento e respeito pelos direitos humanos, além do propósito do Due diligence.

Diante desse contexto, a ISO 14001 representa um elemento que compõe o pilar ambiental, a ISO 9001 representa um elemento que compõe o pilar econômico, a OHSAS 18001 e a NBR 16001 representam alguns elementos que compõem o pilar social. Posteriormente as normas foram lidas, interpretadas e seus requisitos foram listados e inseridos nas colunas da Matriz de Relação Teórica.

\subsection{Etapa 2 - Identificação dos requisitos da sustentabilidade empresarial}

O objetivo dessa etapa foi identificar os requisitos da sustentabilidade empresarial. Para isso foi realizada uma revisão bibliográfica exploratória sobre a temática e identificou-se que existem muitos estudos que abordam a questão da sustentabilidade empresarial. Desses estudos poderia ser extraído os requisitos da sustentabilidade, no entanto, não haveria tempo hábil para análise de todos esses trabalhos. Sendo assim, consideramos três documentos que apontam os principais indicadores de sustentabilidade que podem ser utilizados por empresas que desejam alcançar um maior nível de maturidade nesse assunto.

Os requisitos da sustentabilidade empresarial foram baseados no Índice de Sustentabilidade Corporativa (ISE), Indicadores Ethos e o Global Reporting Initiative (GRI), considerando o princípio de "materialidade". Com isso, considerou-se que essas ferramentas agrupam os mais importantes indicadores de sustentabilidade empresarial.

A extração dos requisitos da sustentabilidade empresarial seguiu os seguintes passos: 
1) Leitura e listagem dos indicadores apresentados pelo documento denominado “G4 Diretrizes para relato de sustentabilidade: princípios para relato e conteúdo padrão" disponibilizado pelo Global Reporting Initiative que estabelece diretrizes para empresas que desejam elaborar seus relatórios de acordo com o GRI;

2) Leitura e listagem dos indicadores apresentados pelo documento denominado "Indicadores Ethos de Responsabilidade Social (2013)" disponibilizado pelo Instituto de empresas e responsabilidade social (ETHOS);

3) Leitura e listagem dos indicadores apresentados pelo documento denominado “Questionários ISE 2013” disponibilizado pela BOVESPA;

4) Os indicadores iguais ou similares foram agrupados;

5) Os indicadores foram transformados em requisitos considerando que requisito é: “ a necessidade ou expectativa que é expressa, geralmente, de forma implícita ou obrigatória" (ASSOCIAÇÃO BRASILEIRA DE NORMAS TÉCNICAS, 2005);

6) Posteriormente os requisitos foram enquadrados nas dimensão da sustentabilidade e suas inte-relações;

7) Os requisitos da sustentabilidade empresarial foram listados nas linhas da Matriz de Relação Teórica.

\subsection{Etapa 3 - Preenchimento da Matriz de Relação Teórica}

Após a identificação dos requisitos da sustentabilidade empresarial e a listagem dos requisitos das normas de sistemas de gestão a pesquisadora preencheu a matriz analisando as relações existentes entre cada requisito da sustentabilidade com os requisitos das normas. A escala utilizada nas relações foi adaptada da matriz de relação do método Desdobramento da Função Qualidade (QFD), sendo elas:

\section{Escalas}

* Relação forte (9) - quando os requistos da sustentabilidade empresarial estão diretamente relacionados com os requisitos das normas de sistema de gestão;

* Relação fraca (3) - quando os requistos da sustentabilidade empresarial estão indiretamente relacionados com os requisitos das normas de sistema de gestão;

* Relação nula (0) - quando os requistos da sustentabilidade empresarial não possuem relação com os requisitos das normas de sistema de gestão. 
O quadro 7 representa um recorte da Matriz de Relação Teórica para exemplificar como ocorreu o preenchimento da mesma. Analisando o quadro 7 é possível observar que o requisito da sustentabilidade " 1 . Elaborar política para que os indicadores/dados/informações advindos do processo de diálogo e engajamento das partes interessadas sejam, preservadas (quando confidencial), comparáveis, confiáveis, relevantes e compreensíveis por suas partes interessadas (Ethos, 2013) e (ISE, 2013)" apresentou relação forte com os seguintes requisitos da NBR 16001: Política da responsabilidade social (3.2) e Identificação das partes interessadas (3.3.1). Diante desse contexto, a pesquisadora assumiu que esses requisitos da NBR 16001 auxiliam diretamente (forte) as empresas a atenderem o requisito da sustentabilidade citado anteriormente o mesmo ocorreu para relações fracas e nulas.

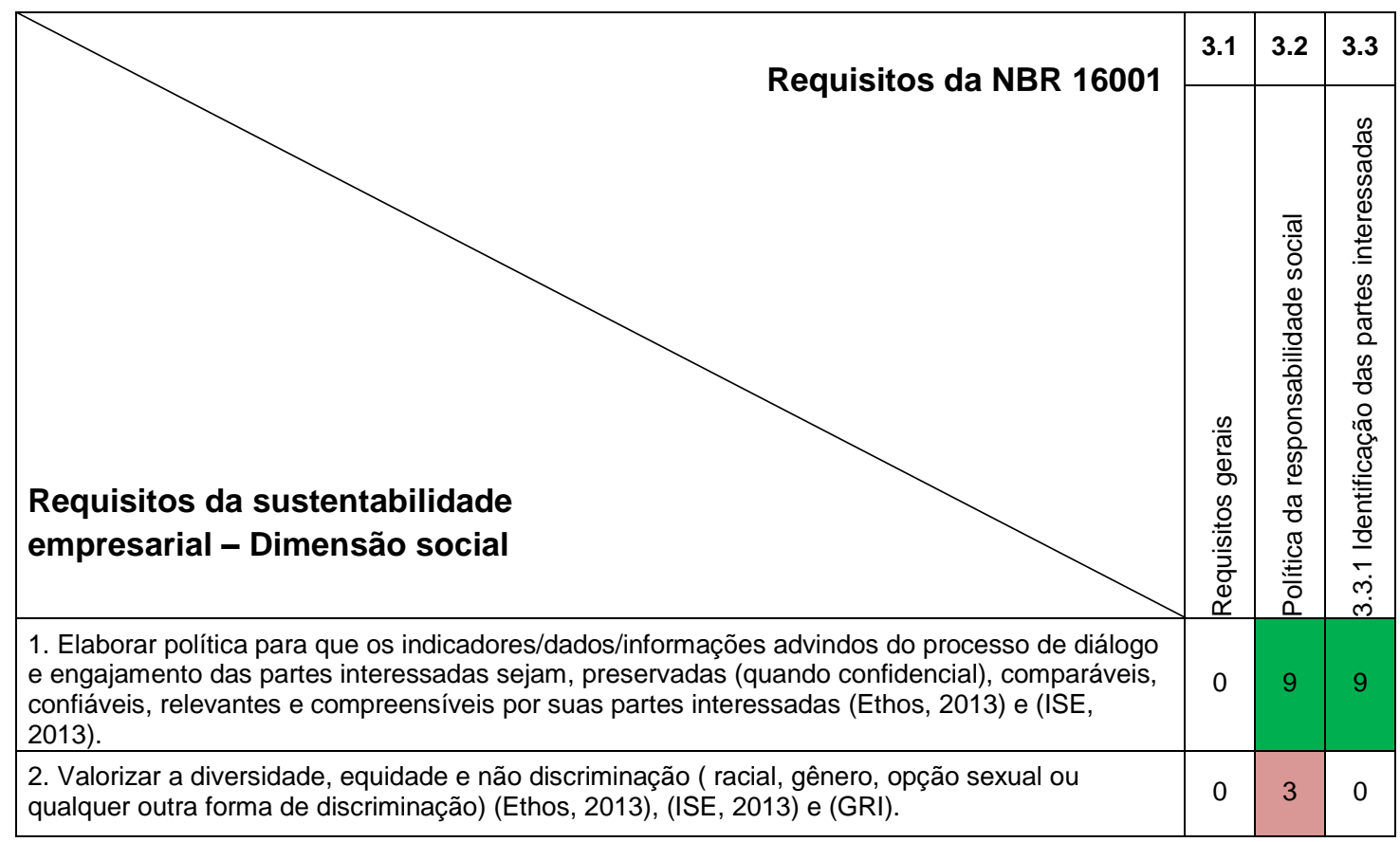

Quadro 7. Recorte da Matriz de Relação Teórica (Elaborado pela autora).

\subsection{Etapa 4 - Consulta com especialistas}

O objetivo dessa etapa foi obter uma análise rigorosa por especialistas em normas de sistema de gestão (ISO 9001, ISO 14001, OHSAS 18001 e NBR 16001) da Matriz de Relação Teórica para garantir uma maior confiabilidade das relações.

\subsubsection{Seleção dos especialistas}

Os critérios de seleção dos especialistas foram os seguintes:

Possuir formação universitária; 
Conhecer detalhadamente pelo menos uma das normas de sistema de gestão (ISO 9001, ISO 14001, OHSAS 18001 e NBR 16001);

> Possuir no mínimo 2 anos de experiência prática utilizando pelo menos uma das normas de sistema de gestão estudas nessa pesquisa;

Desejável que os participantes tenham realizado cursos específicos que abordassem as normas de sistema de gestão.

\subsubsection{Procedimento de coleta de dados}

Primeiramente os especialistas foram contatados via e-mail ou telefone para identificação do interesse na participação da pesquisa, além disso, utilizou-se uma rede social que ajuda a encontrar conexões profissionais para divulgar a pesquisa e encontrar especialista interessados em participar da pesquisa. Após o aceite foi encaminhado via e-mail o termo de declaração de escopo (Apêndice 1) que apresentou o objetivo da pesquisa, justificativa e garantia de sigilo de possíveis informações confidenciais das empresas que os especialistas trabalham.

Para a coleta de dados foi utilizado um questionário semi-estruturado. No momento das entrevistas foram realizadas apresentações referentes a pesquisa para que os especialistas pudessem entender o objetivo do estudo. Posteriormente, a pesquisadora explicou para os especialistas a forma de preenchimento da Matriz de Relação Teórica. As etapas para a realização desses processos estão descritas a seguir:

\section{Etapa 1}

Após as explicações da pesquisadora a mesma coletou informações generalizadas a respeito dos especialistas, sobre suas experiências profissionais, entre outras.

\section{Questões}

1) Qual sua formação acadêmica?

2) Quantos anos o(a) Sr(a) trabalha com as normas ISO 9001, ISO 14001, OHSAS 18001 ou NBR 16001 ?

3) $O(A) \operatorname{Sr}($ a) realizou curso(s) específicos relacionados a pelo menos uma das normas?

\section{Etapa 2}


A pesquisadora explicou como os especialistas deveriam preencher a Matriz de Relação Teórica (ver sessão 3.3). A princípio o intuito era que os especialistas preenchessem a Matriz de Relação no momento da entrevista. No entanto, a partir da $1^{\circ}$ entrevista observou-se que seria inviável, pois essa análise demanda tempo e atenção no momento do preenchimento. Sendo assim, após as explicações foi estabelecido um prazo para que os especialistas encaminhassem via e-mail a Matriz de Relação preenchida.

\section{Etapa 3}

Juntamente com a Matriz de Relação Teórica os especialista puderam responder a seguinte questão: Quais outros requisitos a norma analisada atende que não foram apresentados na Matriz de Relacionamento?

Quando não foi possível realizar entrevistas presenciais as informações necessárias para a realização da consulta foram enviadas via e-mail para os especialistas que posteriormente enviaram a Matriz de Relação preenchida com as relações.

As informações referentes à experiência dos especialistas estão descritas no quadro 8 a seguir:

\begin{tabular}{c|c|c|c|c}
\hline Norma & Especialistas & Formação Acadêmica & $\begin{array}{c}\text { Anos de } \\
\text { experiência }\end{array}$ & $\begin{array}{c}\text { Realizou curso } \\
\text { específico }\end{array}$ \\
\hline \multirow{2}{*}{$\begin{array}{c}\text { ISO } \\
14001\end{array}$} & 1 & Biologia & 3 anos & Curso auditor interno \\
\cline { 2 - 5 } & 2 & $\begin{array}{c}\text { Pós-graduação em } \\
\text { gestão ambiental }\end{array}$ & 4 anos & Curso de auditor líder \\
\cline { 2 - 5 } & 3 & Engenharia de Produção & 5 anos & Curso auditor interno \\
\cline { 2 - 5 } ISO & 4 & Engenharia de materiais & 2 anos & Curso de auditor líder \\
\hline 9001 & 2 & $\begin{array}{c}\text { Pós-graduação em } \\
\text { gestão ambiental }\end{array}$ & 4 anos & Curso de auditor líder \\
\cline { 2 - 5 } & 3 & Engenharia de Produção & 5 anos & Curso auditor interno \\
\hline NBR & 5 & Administração & 8 anos & Não \\
\hline $\begin{array}{c}\text { OHSAS } \\
18001\end{array}$ & 6 & $\begin{array}{c}\text { Pós-graduação em meio } \\
\text { ambiente }\end{array}$ & 18 anos & Curso de auditor líder \\
\hline
\end{tabular}

Quadro 8. Informações referentes à experiência dos especialistas (Elaborado pela autora).

Foram convidados cerca de 55 especialistas, no entanto, apenas 6 aceitaram participar da pesquisa. Alguns justificaram a não participação devido ao tempo e 
atenção necessária que deveriam ser dispensada no preenchimento das matrizes e outros especialista não responderam o e-mail.

Sendo assim, dentre os 6 especialistas 3 preencheram a Matriz de Relação referente a ISO 14001, 3 preencheram a Matriz referente a ISO 9001, 1 preencheu a Matriz de Relação referente a NBR 16001 e 1 preencheu a Matriz de Relação referente a OHSAS 18001. Dois especialistas preencheram tanto a Matriz de Relação referente a ISO 14001 e a ISO 9001. O período médio para a entrega da matriz de relação preenchida foi de aproximadamente 2 mês após o primeiro contato com os especialistas. Além disso, a pesquisadora também preencheu todas as matrizes no papel de especialista acadêmica.

\subsection{Etapa 5 - Análise dos dados e construção da Matriz de Relação Consolidada}

Após o recebimento das matrizes preenchidas pelos especialistas foi elaborado a Matriz de Relação Consolidada seguindo os seguintes passos: 1) os dados provenientes das matrizes preenchidas pelos especialistas foram transferidos para uma planilha digital separadas de acordo com as normas analisadas e 2) calculou-se as médias de cada relação atribuída pelos especialistas e pela pesquisadora de acordo com cada norma. Sendo assim, a Matriz de Relação Consolidada representa os valores médios das opiniões (considerando que $0=$ relação nula, $3=$ relação fraca e $9=$ relação forte) dos especialistas e da pesquisadora.

Como a Matriz de Relação Consolidada é formada por médias (global, geral e valor médio) adota-se a partir desse momento a seguinte escala de análise para melhor compreensão e interpretação dos resultados como mostra o quadro 9:

$$
\begin{gathered}
0=\text { Relação nula (branco) } \\
0>\mathrm{e} \leq 1,5=\text { Relação fraca (marrom) } \\
1,5>\mathrm{e} \leq 3=\text { Relação moderada (rosa) } \\
3>\mathrm{e} \leq 9=\text { Relação forte (verde) }
\end{gathered}
$$

Quadro 9. Escala de análise dos dados (Elaborado pela autora). 
Para compreensão dos resultados é pertinente considerar como foram calculadas as seguintes médias:

Média global $=$ a média de todas as relações existentes considerando cada dimensão;

Média geral $=$ é a média do relacionamento entre cada requisito da sustentabilidade com cada requisito das normas de sistemas de gestão (médias das linhas ou das colunas); e

Valor médio $=$ é a média individual de cada relação de acordo com as respostas dadas pelos especialistas e pela pesquisadora (valor de cada célula).

A seguir o quadro 10 apresenta um recorte da Matriz de Relação Consolidada para exemplificar.

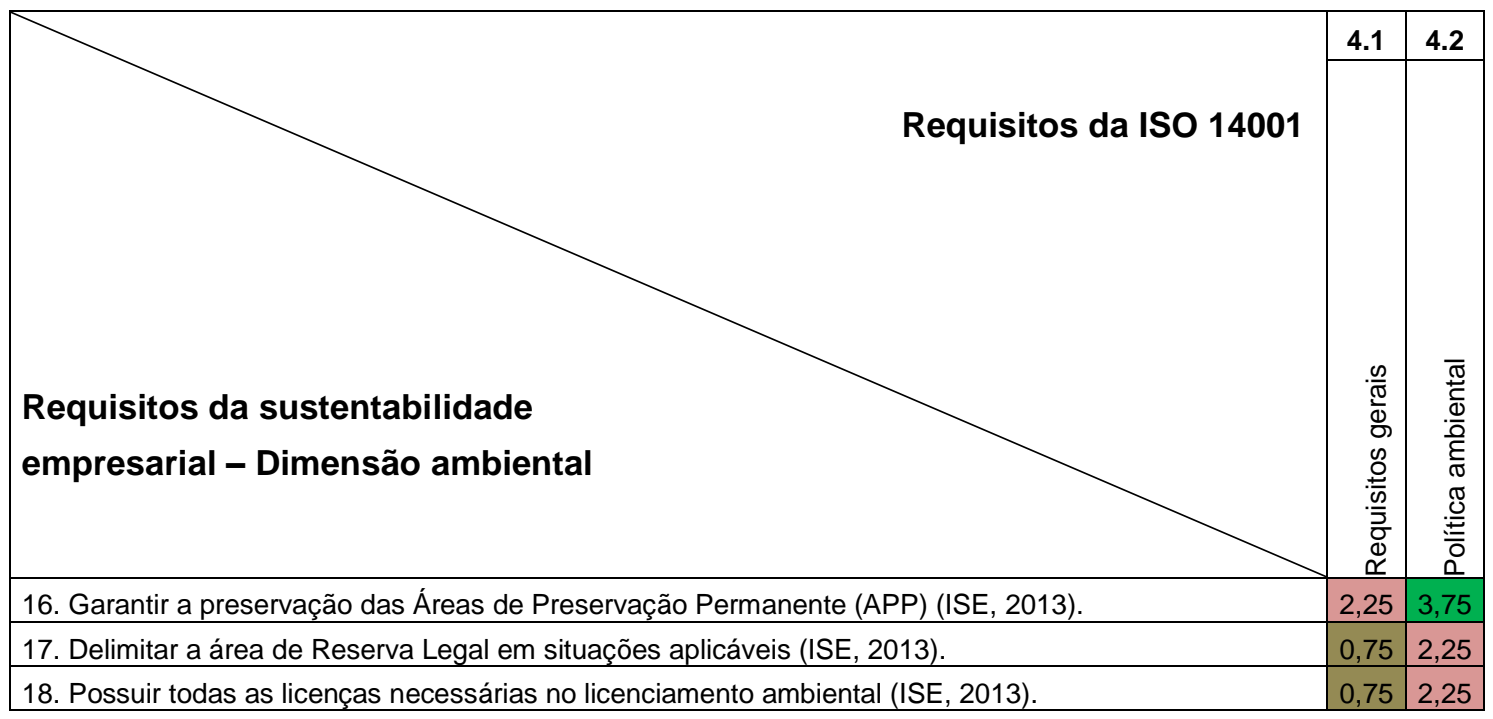

Quadro 10. Recorte da Matriz de Relação Consolidada (Elaborado pela autora).

O método de pesquisa utilizado permite que os usuários interpretem os resultados das seguintes maneiras:

1. Considerando os valores médios (valor de cada célula). Esta maneira permite que o usuário identifique a relação existente entre cada requisito da sustentabilidade empresarial com cada requisito da norma de sistema de gestão utilizado;

2. Analisando e interpretando os valores das médias globais (média das linhas e das colunas). Esta maneira permite que o usuário interprete a relação geral de cada requisito da sustentabilidade com os vários requisitos dos sistemas de 
gestão (linha) ou de cada requisito de um sistema de gestão específico com vários requisitos de sustentabilidade (coluna);

3. Analisando e interpretando os valores das médias globais (média de todas as relações existentes considerando cada dimensão). Esta maneira permite que o usuário identifique a relação global de todos os requisitos da sustentabilidade com a norma de sistema de gestão analisada.

Nesse estudo os pesquisadores optaram pelas opções de análises número 2 e 3, pois as relações entre os requisitos da sustentabilidade e os requisitos da norma de sistema de gestão foram analisadas considerando as médias gerais e globais. Essa forma de análise foi utilizada, pois os pesquisadores desejavam identificar as relações existentes considerando as normas como um todo e não analisar detalhamento como é o caso da opção 1. Os atores entendem que, embora apenas um requisito de algum sistema de gestão possa ser responsável e suficiente por atender um ou mais requisitos de sustentabilidade, o suporte seria mais efetivo se vários requisitos das normas se relacionarem com um requisito de sustentabilidade. 


\section{Capíula 4}

\section{RESULTADOS E DISCUSSÕES}

Analisando as médias globais apresentadas nas matrizes observa-se que a ISO 9001 apresentou relação fraca com a sustentabilidade empresarial em todas as dimensões. Todas as médias globais identificadas apresentaram valores abaixo de $1 \mathrm{e}$ alguns próximos de 0 como mostra o quadro 11 .

Com relação a OHSAS 18001 de acordo com as médias globais observa-se que a dimensão ambiental - social - econômica apresentou relação nula com a sustentabilidade empresarial. As demais médias globais apresentaram valores próximos a 0 demonstrando relação fraca (quadro 11).

Analisando as médias globais identificadas nas matrizes referentes as ISO 14001 observa-se esse padrão normativo apresenta relação moderada com a sustentabilidade empresarial. As dimensões que apresentaram as maiores médias globais foram a econômico - ambiental $(2,07)$ e a ambiental $(2,06)$. A dimensão que apresentou a menor média global foi a econômica $(0,22)$ como mostra o quadro 11 .

Com relação a NBR 16001 observa-se que esse padrão normativo apresenta relação forte com a sustentabilidade empresarial, já que dentre as 7 dimensão analisadas 4 apresentaram relação forte sendo elas: social-ambiental-econômica $(3,45)$, socioeconômica $(3,31)$, econômico-ambiental $(3,2)$ e ambiental $(3,04)$ como mostra o quadro 11. Esses resultados provavelmente estão relacionados ao fato da NBR 16001 abordar questões sociais, ambientais e econômicas em seu escopo.

\begin{tabular}{c|c|c|c|c}
\cline { 2 - 5 } & \multicolumn{5}{c}{ Normas de sistemas de gestão } \\
\hline Dimensões & NBR 16001 & ISO 14001 & ISO 9001 & OHSAS 18001 \\
\hline Social & 2,4 & 0,7 & 0,8 & 0,3 \\
\hline Ambiental & 3,1 & 2,1 & 0,2 & 0,1 \\
\hline Econômica & 1,1 & 0,2 & 0,1 & 0,1 \\
\hline Socioambiental & 2,8 & 1,6 & 0,1 & 0,1 \\
\hline Socioeconômica & 3,3 & 0,4 & 0,6 & 0,5 \\
\hline Econômico - ambiental & 3,2 & 2,1 & 0,2 & 0,2 \\
\hline Social - ambiental - econômica & 3,5 & 1,7 & 0,3 & 0 \\
\hline
\end{tabular}

Quadro 11. Visão geral das relações existentes entre as normas de sistema de gestão e os requisitos da sustentabilidade corporativa considerando as médias globais. Onde: verde $=$ relação forte; rosa = relação moderada; marrom = relação fraca e branco = relação nula . 


\subsection{ABNT NBR ISO 9001:2008 - Sistema de gestão da qualidade - Requisitos.}

A seguir o quadro 12 apresenta um mapeamento do relacionamento da norma ISO 9001 com os requisitos da sustentabilidade que foram resumidos em temas centrais. Os resultados detalhados podem ser encontrados nos apêndices desse trabalho. As discussões estão baseadas em apenas algumas temáticas que foram consideradas mais relevantes. Para a elaboração desse quadro foram considerado as médias gerais.

Considerando a dimensão social as temáticas que apresentaram relação fraca com a ISO 9001 foram: valorizar a diversidade, equidade, não descriminação, princípios éticos, direitos humanos, entre outras. Diante desse contexto, a norma ISO 9001 não apresenta requisitos específicos que abordem essas temática, no entanto, esses assuntos estão indiretamente ligados ao compromisso que as organizações assumem perante as partes interessadas.

A temática relacionada a saúde e segurança no trabalho apresentou relação fraca com a ISO 9001. O estudo realizado por Depexe e Paladini (2008) no estado de Santa Catarina (BR) com 14 empresas do setor de construção civil que teve como objetivo identificar a percepção das empresas em relação aos benefícios obtidos pela implantação e certificação de sistema de gestão da qualidade apontou que os principais benefícios relacionados aos funcionários são: melhoria da saúde e segurança no trabalho, aumento da satisfação com o trabalho, aumento das sugestões dos trabalhadores, redução de rotatividade, redução de absenteísmo e aumento da qualificação dos trabalhadores que está associada a preparação interna. Sendo assim, o estudo realizado por Depexe e Paladini (2008) confirma a relação identificada no presente estudo, demonstrando que a ISO 9001 pode auxiliar as empresas a incorporarem (indiretamente) questões associadas a saúde e segurança no trabalho.

A temática que envolve treinamento apresentou relação fraca com a ISO 9001 considerando a média geral $(0,37)$. No entanto, analisando pontualmente a Matriz de Relação Consolidada (apêndice 3) é possível observar que essa temática apresentou relação forte com o requisito 6.2.2 Competência, treinamento e conscientização (valor médio $=5,25$ ). 


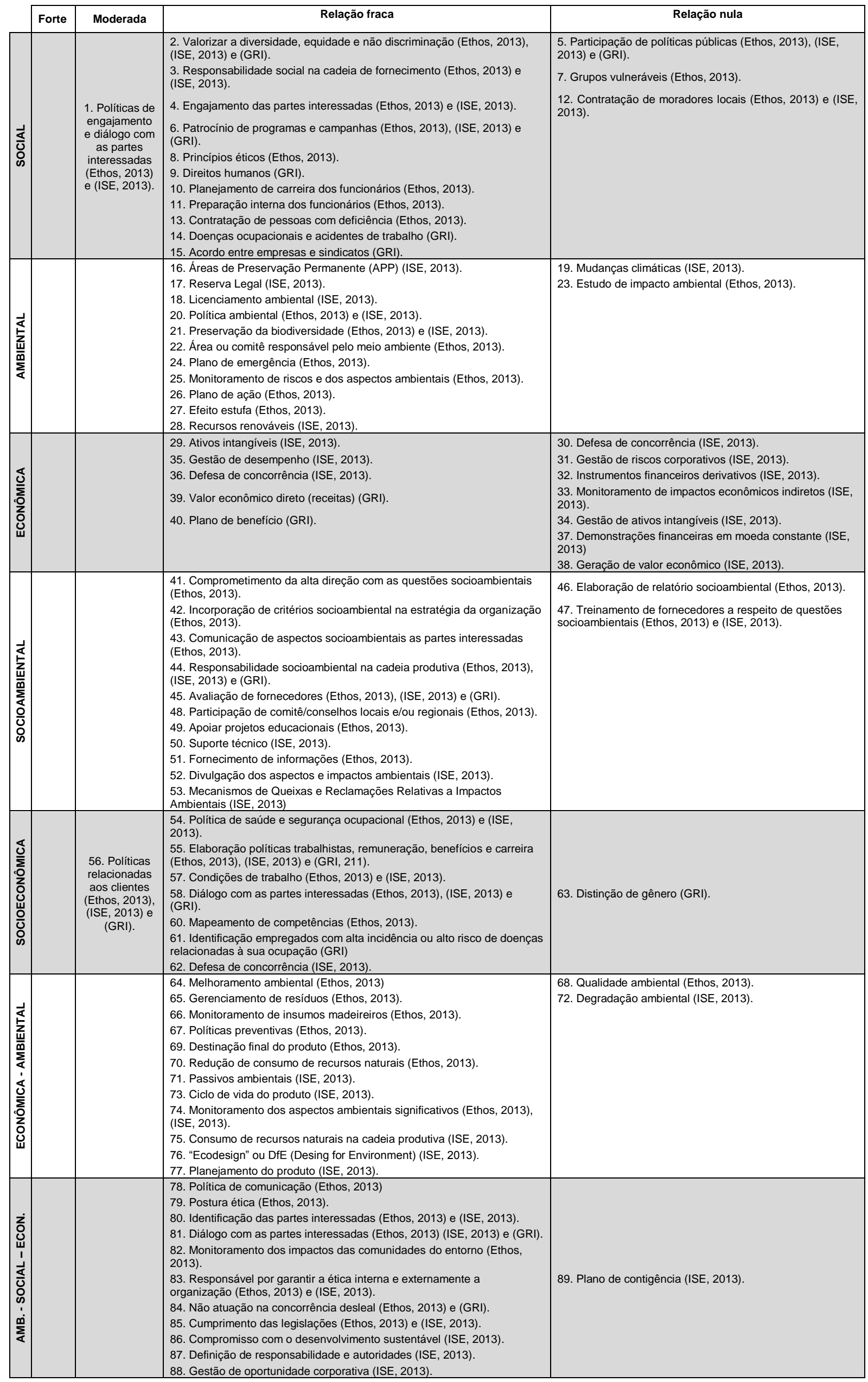

Quadro 12. Relacionamento entre a ISO 9001 e os requisitos da sustentabilidade empresarial. 
As temáticas que apresentaram relações nulas com a ISO 9001 foram: oferecer oportunidade a grupos vulneráveis, engajamento da população local e participação de elaboração, implementação e avaliação de políticas públicas. Essas relações foram nulas pelo fato da ISO 9001 não abordar questões específicas de responsabilidade social.

Com relação a dimensão ambiental as temáticas que apresentaram relação nula com a ISO 9001 foram: mudanças climáticas e estudo de impacto ambiental. Essas relações foram nulas pelo fato da ISO 9001 não abordar questões ambientais específicas.

As temáticas que apresentaram relações nulas com a ISO 9001 inseridas na dimensão econômica foram: defesa de concorrência, gestão de riscos corporativos, monitoramento de impactos econômicos, gestão de ativos intangíveis, lucro econômico, entre outros. Não foi identificado nenhuma relação forte ou moderada. No entanto, de acordo com a Associação Brasileira de Normas Técnicas (2008b) os benefícios associados com a adoção de um SGQ baseado na ISO 9001 são: maior lucratividade, maiores receitas, melhor desempenho orçamentários, redução de custos, melhor fluxo de caixa, maior retorno sobre o investimento, melhor competitividade, maior retenção e lealdade dos clientes, maior eficácia na tomada de decisão, uso otimizado dos recursos disponíveis, aumento da responsabilidade dos empregados, desenvolvimento do capital intelectual, processos otimizados, efetivos e eficientes, melhor desempenho na cadeia de suprimento, menor tempo de lançamento de produtos e melhor desempenho organizacional, credibilidade e sustentabilidade. Sendo assim, de acordo com a Associação Brasileira de Normas Técnicas (2008b) a ISO 9001 pode auxiliar as empresas (indiretamente) a obter benéficos econômicos confirmando a relação encontrada no presente estudo.

Analisando a dimensão socioambiental não se identificou nenhuma relação forte ou moderada entre as temáticas extraídas dos requisitos da sustentabilidade e a ISO 9001. As temáticas que apresentaram relações fracas foram: responsabilidade socioambiental, incorporação de critérios socioambientais na estratégia organizacional, apoiar projeto de educação ambiental, entre outros. As temáticas que apresentaram relações nulas com a ISO 9001 foram relacionadas a elaboração de relatório e treinamento socioambiental. Essas temáticas apresentaram relações fracas ou nulas pelo fato da ISO 9001 não considerar em seu escopo questões sociais e ambientais. No entanto, as empresas podem incorporar em seu escopo essas questões. 
Considerando a dimensão socioeconômica a temática que apresentou relação moderada com a ISO 9001 está associada a elaboração de políticas relacionadas aos clientes. Essa temática está inserida no requisito 5.2 Foco no cliente da norma. De acordo com a Associação Brasileira de Normas Técnicas (2008) a alta direção deve se comprometer que os requisitos dos clientes sejam atendidos para garantir sua satisfação. Além disso, foco no cliente é um dos princípios de gestão de qualidade, tais como liderança, envolvimento de pessoas, abordagem de processo, abordagem sistêmica para a gestão, melhoria contínua, abordagem factual para tomada de decisão e benefícios mútuos nas relações com os fornecedores.

A temática condições de trabalho apresentou relação fraca com a ISO 9001 considerando a média geral $(1,26)$. No entanto, a norma apresenta o requisito 6.4 Ambiente de trabalho que evidencia a necessidade das organizações gerenciarem o ambiente de trabalho para que o atendimento aos requisitos do produto sejam alcançados. Analisando pontualmente a Matriz de Relação Consolidada (apêndice 7) o valor médio $(4,5)$ da relação entre o requisito da sustentabilidade empresarial que aborda esse assunto e o requisito da norma foi forte.

As temáticas políticas de saúde e segurança no trabalho, políticas trabalhistas, remuneração e benefícios apresentaram relação fraca com a ISO 9001. Essa norma não apresenta requisitos específicos relacionados a esses assuntos, no entanto, estão associados ao atendimento de requisitos legais e obrigatórios em qualquer organização.

Com relação a dimensão econômica - ambiental as temáticas que apresentaram relação nula com a ISO 9001 foram: qualidade ambiental e degradação ambiental. Essas relações foram nulas pelo fato da ISO 9001 não abordar questões ambientais. O restante dos requisitos inseridos nessa dimensão apresentaram relação fraca.

Analisando a dimensão ambiental - social - econômica a temática que apresentou relação nula com a ISO 9001 foi: plano de contingência. Essa relação foi nula pelo fato da ISO 9001 não abordar questões ambientais e econômicas específicas. Os demais requisitos inseridos nessa dimensão apresentaram relação fraca.

\subsection{ABNT NBR ISO 14001:2004 - Sistema de gestão ambiental: Requisitos com orientações para o uso.}

A seguir o quadro 13 apresenta um mapeamento do relacionamento da norma ISO 14001 com os requisitos da sustentabilidade que foram resumidos em temas centrais. Os 
resultados detalhados podem ser encontrados nos apêndices desse trabalho. As discussões estão baseadas em apenas algumas temática que foram consideradas mais relevantes.

Considerando a dimensão social a temática que apresentou relação moderada com a ISO 14001 está associada com a garantia dos direitos humanos. A ISO 14001 não possui requisito específico relacionado a essa temática, no entanto, os direitos humanos devem ser assegurados em qualquer situação e contexto.

Considerando a dimensão ambiental a preservação de Áreas de Preservação Permanente (APP) apresentou relação forte com a ISO 14001. As temáticas licenciamento ambiental, mudanças climáticas, estudo de impacto ambiental, entre outros apresentaram relação moderada. Observa-se que todas as temáticas listadas anteriormente estão relacionadas ao atendimento aos requisitos legais e com o compromisso que as organizações estabelecem quando implementam um sistema de gestão ambiental baseados na ISO 14001. De acordo com o estudo realizado por Heras-Saizarbitoria; Landín e Molina-Azorín (2011) que teve como objetivo identificar as motivações que levam as empresas a adotarem a ISO 14001 o cumprimento das leis e regulamentos ambientais foi apontado como uma das principais causas que levam as empresas a implementarem esse sistema.

A elaboração de política ambiental apresentou relação forte com a ISO 14001. Essa temática está inserida no requisito 4.2 Política Ambiental apontando os compromissos das organizações em manterem o sistema de gestão ambiental. 


\begin{tabular}{|c|c|c|c|c|}
\hline & $\begin{array}{c}\text { Relação } \\
\text { forte }\end{array}$ & Relação moderada & Relação fraca & Rel. nula \\
\hline $\begin{array}{l}\frac{1}{0} \\
\\
\end{array}$ & & 9. Direitos humanos (GRI). & $\begin{array}{l}\text { 1. Políticas de engajamento e diálogo com as partes interessadas } \\
\text { (Ethos, 2013) e (ISE, 2013). } \\
\text { 2. Valorizar a diversidade, equidade e não discriminação (Ethos, } \\
\text { 2013), (ISE, 2013) e (GRI). } \\
\text { 3. Responsabilidade social na cadeia de fornecimento (Ethos, } \\
\text { 2013) e (ISE, 2013). } \\
\text { 4. Engajamento das partes interessadas (Ethos, 2013) e (ISE, } \\
\text { 2013). } \\
\text { 5. Participação de políticas públicas (Ethos, 2013), (ISE, 2013) e } \\
\text { (GRI). } \\
\text { 6. Patrocínio de programas e campanhas (Ethos, 2013), (ISE, } \\
\text { 2013) e (GRI). } \\
\text { 7. Grupos vulneráveis (Ethos, 2013). } \\
\text { 8. Princípios éticos (Ethos, 2013). } \\
\text { 10. Planejamento de carreira dos funcionários (Ethos, 2013). } \\
\text { 11. Preparaçãoo interna dos funcionários (Ethos, 2013). } \\
\text { 12. Contratacaão de moradores locais (Ethos, 2013) e (ISE, 2013). } \\
\text { 13. Contratacãa de pessoas com deficiência (Ethos, 2013). } \\
\text { 14. Doenças ocupacionais e acidentes de trabalho (GRI). } \\
\text { 15. Acordo entre empresas e sindicatos (GRI). }\end{array}$ & \\
\hline 它 & \begin{tabular}{|l} 
16. Áreas de \\
Preservação \\
Permanente \\
(APP) (ISE, \\
2013). \\
20. Política \\
ambiental \\
(Ethos, \\
2013) e (ISE, \\
2013). \\
\end{tabular} & $\begin{array}{l}\text { 17. Reserva Legal (ISE, 2013). } \\
\text { 18. Licenciamento ambiental (ISE, 2013). } \\
\text { 19. Mudanças climáticas (ISE, 2013). } \\
\text { 21. Preservação da biodiversidade (Ethos, 2013) e (ISE, 2013). } \\
\text { 22. Área ou comitê responsável pelo meio ambiente (Ethos, } \\
\text { 2013). } \\
\text { 23. Estudo de impacto ambiental (Ethos, 2013). } \\
\text { 24. Plano de emergência (Ethos, 2013). } \\
\text { 25. Monitoramento de riscos e dos aspectos ambientais (Ethos, } \\
\text { 2013). } \\
\end{array}$ & $\begin{array}{l}\text { 26. Plano de ação (Ethos, 2013). } \\
\text { 27. Efeito estufa (Ethos, 2013). } \\
\text { 28. Recursos renováveis (ISE, 2013). }\end{array}$ & \\
\hline 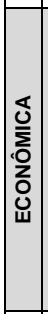 & & & $\begin{array}{l}\text { 29. Ativos intangíveis (ISE, 2013). } \\
\text { 30. Defesa de concorrência (ISE, 2013). } \\
\text { 31. Gestão de riscos corporativos (ISE, 2013). } \\
\text { 32. Instrumentos financeiros derivativos (ISE, 2013). } \\
\text { 33. Monitoramento de impactos econômicos indiretos (ISE, 2013). } \\
\text { 34. Gestão de ativos intangíveis (ISE, 2013). } \\
\text { 35. Gestão de desempenho (ISE, 2013). } \\
\text { 36. Defesa de concorrência (ISE, 2013). } \\
\text { 37. Demonstrações financeiras em moeda constante (ISE, 2013) } \\
\text { 38. Geraçãoo de valor econômico (ISE, 2013). } \\
\text { 39. Valor econômico direto (receitas) (GRI). } \\
\end{array}$ & $\begin{array}{l}\text { 40. Plano de } \\
\text { benefício } \\
\text { (GRI). }\end{array}$ \\
\hline 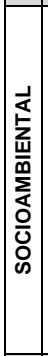 & & $\begin{array}{l}\text { 41. Comprometimento da alta direção com as questōes } \\
\text { socioambientais (Ethos, 2013). } \\
\text { 42. Incorporação de criterios socioambiental na estratégia da } \\
\text { organização (Ethos, 2013). } \\
\text { 43. Comunicação de aspectos socioambientais as partes } \\
\text { interessadas Ethos, , 2013). } \\
\text { 44. Responsabilidade socioambiental na cadeia produtiva } \\
\text { (Ethos, 2013), (ISE, 2013) e (GRI). } \\
\text { 45. Avaliação de fornecedores (Ethos, 2013), (ISE, 2013) e } \\
\text { (GRI). } \\
\text { 52. Divulgaçãa dos aspectos e impactos ambientais (ISE, } \\
\text { 2013). } \\
\text { 53. Mecanismos de Queixas e Reclamações Relativas a } \\
\text { Impactos Ambientais (ISE, 2013) }\end{array}$ & $\begin{array}{l}\text { 46. Elaboração de relatório socioambiental (Ethos, 2013). } \\
\text { 47. Treinamento de fornecedores a respeito de questões } \\
\text { socioambientais (Ethos, 2013) e (ISE, 2013). } \\
\text { 48. Participação de comitê/conselhos locais e/ou regionais (Ethos, } \\
\text { 2013). } \\
\text { 49. Apoiar projetos educacionais (Ethos, 2013). } \\
\text { 50. Suporte técnico (ISE, 2013). } \\
\text { 51. Fornecimento de informações (Ethos, 2013). }\end{array}$ & \\
\hline 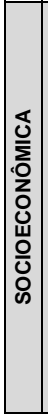 & & & $\begin{array}{l}\text { 54. Política de saúde e segurança ocupacional (Ethos, 2013) e } \\
\text { (ISE, 2013). } \\
\text { 55. Elaboração políticas trabalhistas, remuneração, benefícios e } \\
\text { carreira (Ethos, 2013), (ISE, 2013) e (GRI, 211). } \\
56 \text {. Políticas relacionadas aos clientes (Ethos, 2013), (ISE, 2013) } \\
\text { e (GRI). } \\
\text { 57. Condições de trabalho (Ethos, 2013) e (ISE, 2013). } \\
\text { 58. Diálogo com as partes interessadas (Ethos, 2013), (ISE, 2013) } \\
\text { e (GRI). } \\
\text { 59. Inclusão de fornecedores locais (Ethos, 2013) (ISE, 2013) e } \\
\text { (GRI). } \\
\text { 60. Mapeamento de competências (Ethos, 2013). } \\
\text { 61. Identificação empregados com alta incidência ou alto risco de } \\
\text { doenças relacionadas à sua occupação (GRI) } \\
\text { 62. Defesa de concorrência (ISE, 2013). } \\
\text { 63. Distinção de gênero (GRI). }\end{array}$ & \\
\hline 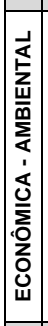 & $\begin{array}{l}65 . \\
\text { Gerenciame } \\
\text { nto de } \\
\text { resíduos } \\
\text { (Ethos, } \\
2013 \text { ). }\end{array}$ & $\begin{array}{l}\text { 64. Melhoramento ambiental (Ethos, 2013) } \\
\text { 66. Monitoramento de insumos madeireiros (Ethos, 2013). } \\
\text { 67. Políticas preventivas (Ethos, 2013). } \\
\text { 68. Qualidade ambienta (Ethos, 2013). } \\
\text { 69. Destinacãá final do produto (Ethos, 2013). } \\
\text { 70. Redução de consumo de recursos naturais (Ethos, 2013). } \\
\text { 71. Passivos ambientais (ISE, 2013). } \\
\text { 74. Monitoramento dos aspectos ambientais significativos } \\
\text { (Ethos, 2013), (ISE, 2013). } \\
\text { 75. Consumo de recursos naturais na cadeia produtiva (ISE, } \\
\text { 2013). } \\
\text { 76. "Ecodesign" ou DfE (Desing for Environment) (ISE, 2013). }\end{array}$ & $\begin{array}{l}\text { 72. Degradacăão ambiental (ISE, 2013). } \\
\text { 73. Ciclo de vida do produto (ISE, 2013). } \\
\text { 77. Planejamento do produto (ISE, 2013). }\end{array}$ & \\
\hline 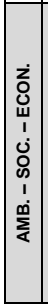 & & $\begin{array}{l}\text { 78. Política de comunicação (Ethos, 2013) } \\
\text { 79. Postura ética (Ethos, 2013). } \\
\text { 80. Identificação das partes interessadas (Ethos, 2013) e (ISE, } \\
\text { 2013). } \\
\text { 82. Monitoramento dos impactos das comunidades do entorno } \\
\text { (Ethos, 2013). } \\
\text { 83. Responsável por garantir a ética interna e externamente a } \\
\text { organização (Ethos, 2013) e (ISE, 2013). } \\
\text { 86. Compromisso com o desenvolvimento sustentável (ISE, } \\
\text { 2013). } \\
\text { 89. Plano de contigência (ISE, 2013). }\end{array}$ & $\begin{array}{l}\text { 81. Diálogo com as partes interessadas (Ethos, 2013) (ISE, 2013) } \\
\text { e (GRI). } \\
\text { 84. Não atuação na concorrência desleal (Ethos, 2013) e (GRI). } \\
\text { 85. Cumprimento das legislações (Ethos, 2013) e (ISE, 2013). } \\
\text { 87. Definição de responsabilidade e autoridades (ISE, 2013). }\end{array}$ & \\
\hline
\end{tabular}

Quadro 13. Relacionamento entre a ISO 14001 e os requisitos da sustentabilidade empresarial. 
Analisando a dimensão econômica as temáticas que apresentaram relação fraca com a ISO 14001 foram: gestão de risco corporativo, gestão de desempenho, gestão de ativos intangíveis, valor econômico direto, entre outros. No entanto, os autores Bansal e Bogner (2002) afirmam que um SGA adotado de maneira correta pode permitir que as empresas alcancem maior eficiência e eficácia organizacional, através da diminuição dos custos e dos impactos ambientais. Além disso, empresas que adotaram a ISO 14001 obtêm vantagens competitivas e retornos financeiros superiores se comparado com aquelas que não possuem o certificado. A manutenção e renovação do certificado de um sistema de gestão ambiental (ISO 14001) devem ser significativo o suficiente para justificar os custos financeiros envolvidos. Sendo assim, de acordo com Bansal e Bogner (2002) a ISO 14001 pode auxiliar as empresas (indiretamente) a obter benéficos econômicos confirmando a relação encontrada no presente estudo.

Considerando a dimensão socioambiental a temática comprometimento da alta direção com as questões socioambientais apresentou relação moderada com a ISO 14001 considerando a média geral $(2,33)$. No entanto, de acordo com a Associação Brasileira de Normas Técnicas (2005) a alta administração deve se comprometer em implementar e manter o SGA disponibilizando os recursos necessários (financeiro e humano). Analisando pontualmente a Matriz de Relação Consolidada (apêndice 13) observa-se uma relação forte (valor médio $=3,75$ ) entre o requisito da sustentabilidade empresarial que aborda essa temática e o requisito da ISO 14001 Política Ambiental (4.2).

A divulgação dos aspectos e impactos ambientais foi uma temática que apresentou relação fraca com a ISO 14001 considerando a média geral $(2,42)$. No entanto, essa temática está inserida no requisito 4.3.1 Aspectos ambientais, onde as organizações devem identificar os aspectos e impactos ambientais significativos. Analisando pontualmente a Matriz de Relação Consolidada (apêndice 13) observa-se uma relação forte (valor médio $=6,75$ ) entre o requisito da sustentabilidade empresarial que aborda essa temática e o requisito da ISO 14001 Aspectos ambientais (4.3.1).

Considerando a dimensão socioeconômica as temáticas que abordam relacionamento com clientes, diálogo entre os clientes, funcionários, fornecedores e distribuidores, condição ideal de trabalho e inclusão de fornecedores regionais apresentaram relação fraca com a ISO 14001. No entanto, esses assuntos auxiliam na melhora da imagem das organizações perante as partes interessadas. De acordo com o estudo realizado por Heras-Saizarbitoria; Landín e Molina-Azorín (2011) uma das 
principais motivações que levam as empresas a implementarem um SGA é a melhora da imagem corporativa. O estudo realizado por Tan (2005) que teve como objetivo identificar os benefícios derivados da implementação da ISO 14001 em empresas localizadas na Malásia (18 empresas foram analisadas) apontou a melhora da imagem empresarial perante as partes interessadas como um benefício, sendo que $94 \%$ dos entrevistados concordaram com essa afirmação.

Considerando a dimensão econômica - ambiental a temática gerenciamento de resíduos apresentou relação forte com a ISO 14001 e está inserida no requisito 4.3.2 Requisitos legais e outros da norma.

A elaboração de políticas preventivas apresentou relação moderada com a ISO 14001. No entanto, essa temática está inserida no requisito 4.2 Política ambiental, onde as organizações devem assumir o compromisso com a melhoria contínua e com a prevenção da poluição.

Analisando os resultados obtidos na dimensão ambiental - social - econômica a temática compromisso com o desenvolvimento sustentável apresentou relação moderada com a ISO 14001. Esse resultado indica que a ISO 14001 é apenas um instrumento que auxilia no desenvolvimento sustentável.

\subsection{ABNT NBR 16001:2012 - Responsabilidade social - Sistema de gestão - requisitos.}

A seguir o quadro 14 apresenta um mapeamento do relacionamento da norma NBR 16001 com os requisitos da sustentabilidade que foram resumidos em temas centrais. Os resultados detalhados podem ser encontrados nos apêndices desse trabalho. As discussões estão baseadas em apenas algumas temática que foram consideradas mais relevantes.

Com relação a dimensão social as temáticas que apresentaram relação forte com a NBR 16001 foram: valorização da diversidade, equidade, não discriminação, engajamento das partes interessadas, direitos humanos e doenças e acidentes no trabalho. Essas temáticas podem ser identificadas claramente na NBR 16001 evidenciando a existência de relações fortes entre esses assuntos. 


\begin{tabular}{|c|c|c|c|c|}
\hline & Relação forte & Relação moderada & Relação fraca & Nula \\
\hline 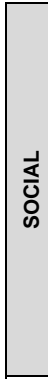 & $\begin{array}{l}\text { 2. Valorizar a diversidade, equidade e não } \\
\text { discriminação (Ethos, 2013), (ISE, 2013) e } \\
\text { (GRI). } \\
\text { 4. Engajamento das partes interessadas (Ethos, } \\
\text { 2013) e (ISE, 2013). } \\
\text { 9. Direitos humanos (GRI). } \\
\text { 14. Doenças ocupacionais e acidentes de } \\
\text { trabalho (GRI). }\end{array}$ & $\begin{array}{l}\text { 1. Políticas de engajamento e diálogo com as } \\
\text { partes interessadas (Ethos, 2013) e (ISE, 2013). } \\
\text { 3. Responsabilidade social na cadeia de } \\
\text { fornecimento (Ethos, 2013) e (ISE, 2013). } \\
\text { 5. Participação de políticas públicas (Ethos, 2013), } \\
\text { (ISE, 2013) e (GRI). } \\
\text { 7. Grupos vulneráveis (Ethos, 2013). } \\
\text { 8. Princípios éticos (Ethos, 2013). } \\
\text { 12. Contratação de moradores locais (Ethos, } \\
\text { 2013) e (ISE, 2013). } \\
\text { 13. Contratação de pessoas com deficiência } \\
\text { (Ethos, 2013). } \\
\text { 15. Acordo entre empresas e sindicatos (GRI). }\end{array}$ & $\begin{array}{l}\text { 6. Patrocínio de programas e campanhas } \\
\text { (Ethos, 2013), (ISE, 2013) e (GRI). } \\
\text { 10. Planejamento de carreira dos } \\
\text { funcionários (Ethos, 2013). } \\
\text { 11. Preparação interna dos funcionários } \\
\text { (Ethos, 2013). }\end{array}$ & \\
\hline$\frac{1}{\stackrel{c}{\leftarrow}}$ & $\begin{array}{l}\text { 16. Áreas de Preservação Permanente (APP) } \\
\text { (ISE, 2013). } \\
\text { 17. Reserva Legal (ISE, 2013). } \\
\text { 18. Licenciamento ambiental (ISE, 2013). } \\
\text { 19. Mudanças climáticas (ISE, 2013). } \\
\text { 21. Preservação da biodiversidade (Ethos, 2013) } \\
\text { e (ISE, 2013). } \\
\text { 23. Estudo de impacto ambiental (Ethos, 2013). } \\
\text { 24. Plano de emergência (Ethos, 2013). } \\
\text { 25. Monitoramento de riscos e dos aspectos } \\
\text { ambientais (Ethos, 2013). }\end{array}$ & $\begin{array}{l}\text { 20. Política ambiental (Ethos, 2013) e (ISE, 2013). } \\
\text { 22. Área ou comitê responsável pelo meio } \\
\text { ambiente (Ethos, 2013). } \\
\text { 27. Efeito estufa (Ethos, 2013). } \\
\text { 28. Recursos renováveis (ISE, 2013). }\end{array}$ & 26. Plano de ação (Ethos, 2013). & \\
\hline 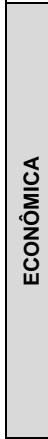 & & & $\begin{array}{l}\text { 29. Ativos intangíveis (ISE, 2013). } \\
\text { 30. Defesa de concorrência (ISE, 2013). } \\
\text { 31. Gestão de riscos corporativos (ISE, } \\
\text { 2013). } \\
\text { 32. Instrumentos financeiros derivativos } \\
\text { (ISE, 2013). } \\
\text { 33. Monitoramento de impactos econômicos } \\
\text { indiretos (ISE, 2013). } \\
\text { 34. Gestão de ativos intangíveis (ISE, 2013). } \\
\text { 35. Gestão de desempenho (ISE, 2013). } \\
\text { 36. Defesa de concorrência (ISE, 2013). } \\
\text { 37. Demonstraços financeiras em moeda } \\
\text { constante (ISE, 2013) } \\
\text { 38. Geração de valor econômico (ISE, 2013). } \\
\text { 39. Valor econômico direto (receitas) (GRI). } \\
\text { 40. Plano de benefício (GRI). }\end{array}$ & \\
\hline 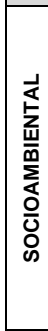 & $\begin{array}{l}\text { 43. Comunicação de aspectos socioambientais } \\
\text { as partes interessadas (Ethos, 2013). } \\
\text { 47. Treinamento de fornecedores a respeito de } \\
\text { questôes socioambientais (Ethos, 2013) e (ISE, } \\
\text { 2013). } \\
\text { 51. Fornecimento de informações (Ethos, 2013). } \\
\text { 52. Divulgação dos aspectos e impactos } \\
\text { ambientais (ISE, 2013). }\end{array}$ & $\begin{array}{l}\text { 41. Comprometimento da alta direção com as } \\
\text { questôes socioambientais (Ethos, 2013). } \\
\text { 42. Incorporação de critérios socioambiental na } \\
\text { estratégia da organização (Ethos, 2013). } \\
\text { 44. Responsabilidade socioambiental na cadeia } \\
\text { produtiva (Ethos, 2013), (ISE, 2013) e (GRI). } \\
\text { 45. Avaliaçãa de fornecedores (Ethos, 2013), } \\
\text { (ISE, 2013) e (GRI). } \\
\text { 49. Apoiar projetos educacionais (Ethos, 2013). } \\
\text { 50. Suporte técnico (ISE, 2013). } \\
\text { 53. Mecanismos de Queixas e Reclamações } \\
\text { Relativas a Impactos Ambientais (ISE, 2013) }\end{array}$ & $\begin{array}{l}\text { 46. Elaboração de relatório socioambiental } \\
\text { (Ethos, 2013). } \\
\text { 48. Participação de comitê/conselhos locais } \\
\text { e/ou regionais (Ethos, 2013). }\end{array}$ & \\
\hline 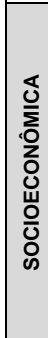 & $\begin{array}{l}\text { 54. Política de saúde e segurança ocupacional } \\
\text { (Ethos, 2013) e (ISE, 2013). } \\
\text { 55. Elaboracaão politicas trabalhistas, } \\
\text { remuneração, benefícios e carreira (Ethos, } \\
\text { 2013), (ISE, 2013) e (GRI, 211). } \\
\text { 56. Políticas relacionadas aos clientes (Ethos, } \\
\text { 2013), (ISE, 2013) e (GRI). } \\
\text { 57. Condiçōes de trabalho (Ethos, 2013) e (ISE, } \\
\text { 2013). } \\
\text { 61. Identificicação empregados com alta } \\
\text { incidência ou alto risco de doenças relacionadas } \\
\text { à sua ocupação (GRI) } \\
\text { 63. Distinção de gênero (GRI). }\end{array}$ & $\begin{array}{l}\text { 58. Diálogo com as partes interessadas (Ethos, } \\
\text { 2013), (ISE, 2013) e (GRI). } \\
\text { 59. Inclusão de fornecedores locais (Ethos, 2013) } \\
\text { (ISE, 2013) e (GRI). } \\
\text { 60. Mapeamento de competências (Ethos, 2013). } \\
\text { 62. Defesa de concorrência (ISE, 2013). }\end{array}$ & & \\
\hline 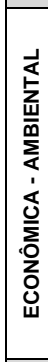 & $\begin{array}{l}\text { 65. Gerenciamento de resíduos (Ethos, 2013). } \\
\text { 67. Políticas preventivas (Ethos, 2013). } \\
\text { 68 .Qualidade ambiental (Ethos, 2013). } \\
\text { 69. Destinação final do produto (Ethos, 2013). } \\
\text { 70. Redução de consumo de recursos naturais } \\
\text { (Ethos, 2013). } \\
\text { 74. Monitoramento dos aspectos ambientais } \\
\text { significativos (Ethos, 2013), (ISE, 2013). } \\
\text { 75. Consumo de recursos naturais na cadeia } \\
\text { produtiva (ISE, 2013). } \\
\text { 76. "Ecodesign" ou DfE (Desing for Environment) } \\
\text { (IIE, 2013). } \\
\text { 77. Planejamento do produto (ISE, 2013). }\end{array}$ & $\begin{array}{l}\text { 71. Passivos ambientais (ISE, 2013). } \\
\text { 72. Degradação ambiental (ISE, 2013). } \\
\text { 73. Ciclo de vida do produto (ISE, 2013). }\end{array}$ & $\begin{array}{l}\text { 64. Melhoramento ambiental (Ethos, 2013) } \\
66 \text {. Monitoramento de insumos madeireiros } \\
\text { (Ethos, 2013). }\end{array}$ & \\
\hline 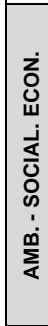 & $\begin{array}{l}\text { 78. Política de comunicação (Ethos, 2013) } \\
\text { 79. Postura ética (Ethos, 2013). } \\
\text { 80. Identificacãa das partes interessadas (Ethos, } \\
\text { 2013) e (ISE, 2013). } \\
\text { 81. Diálogo com as partes interessadas (Ethos, } \\
\text { 2013) (ISE, 2013) e (GRI). } \\
\text { 82. Monitoramento dos impactos das } \\
\text { comunidades do entorno (Ethos, 2013). } \\
\text { 89. Plano de contigência (ISE, 2013). }\end{array}$ & $\begin{array}{l}\text { 83. Responsável por garantir a ética interna e } \\
\text { externamente a organização (Ethos, 2013) e (ISE, } \\
\text { 2013). } \\
\text { 84. Não atuacão na concorrência desleal (Ethos, } \\
\text { 2013) e (GRI). } \\
\text { 85. Cumprimento das legislações(Ethos, 2013) e } \\
\text { (ISE, 2013). } \\
\text { 86. Compromisso com o desenvolvimento } \\
\text { sustentável (ISE, 2013). } \\
\text { 87. Definição de responsabilidade e autoridades } \\
\text { (ISE, 2013). } \\
\text { 88. Gestão de oportunidade corporativa (ISE, } \\
\text { 2013). }\end{array}$ & & \\
\hline
\end{tabular}

Quadro 14. Relacionamento entre a NBR 16001 e os requisitos da sustentabilidade empresarial. 
A garantia de princípios éticos foi uma temática que apresentou relação moderada com a NBR 16001 considerando o media geral $(2,8)$. No entanto, um do princípios da responsabilidade social apontados pela norma é o comportamento ético (3.2. Política da responsabilidade social). Sendo assim, analisando pontualmente a Matriz de Relação Consolidada (apêndice 17) observa-se que essa temática apresentou relação forte (valor médio $=9)$ com o requisito 3.2. Política da responsabilidade social. Esse resultado indica que todos os especialistas acreditam nesse relacionamento.

O assunto relacionado a contratação de moradores locais apresentou relação moderada com a NBR 16001 considerando a média geral $(2,67)$. No entanto, essa temática faz parte do tema central da responsabilidade social (envolvimento e desenvolvimento da comunidade). Sendo assim, analisando pontualmente a Matriz de Relação Consolidada (apêndice 17) observa-se que essa temática apresentou relação forte (valor médio $=9$ ) com o requisito 3.3.2. Temas centrais da responsabilidade social e suas questões. Esse resultado indica que todos os especialistas acreditam nesse relacionamento.

Ao analisar-se a dimensão ambiental é possível identificar as seguintes temáticas que obtiveram relação forte com a NBR 16001: preservar áreas de APP e RL, licenciamento ambiental, mudanças climáticas, preservação da biodiversidade, planos de emergência ambiental, impactos e aspectos ambientais e recursos naturais. Não foi identificado relações nulas. Todos os requisitos da sustentabilidade empresarial inseridos na dimensão ambiental apresentaram relações (forte, moderada ou fraca) pelo fato da NBR 16001 considerar o meio ambiente como um dos temas centrais da responsabilidade social.

Com relação a dimensão econômica todos os requisitos da sustentabilidade empresarial apresentaram relação fraca com a NBR 16001, pois esse padrão não aponta requisitos específicos abordando as temáticas estudadas.

Com relação a dimensão socioambiental a temática comunicação com as partes interessadas apresentou relação forte com a NBR 16001. Esse relacionamento pode ser evidenciado pelo fato da norma apresentar o requisito 3.4.3 Comunicação, onde a organização deve divulgar periodicamente os dados relacionados a responsabilidade social e manter a comunicação com as parte interessadas.

Analisando a dimensão socioeconômica as temáticas que apresentaram relação forte com a NBR 16001 foram: saúde e segurança ocupacional, políticas trabalhistas, relação com os clientes, condições de trabalho e distinção de gênero. Esses assuntos 
podem ser inseridos nos temas centrais da responsabilidade social apontados pela NBR 16001 que são: práticas de trabalho (que envolve emprego e relação de trabalho, condições de trabalho e proteção social, diálogo social, segurança e saúde no trabalho, desenvolvimento humano e treinamento no local de trabalho), direitos humanos (cumplicidade, discriminação, exclusão de grupos vulneráveis, direitos civis e políticos, direitos econômicos e sociais e direitos fundamente no trabalho) e questões relativas ao consumidor (que envolve marketing legal, informações factuais e não tendenciosas, práticas contratuais justas, proteção à segurança e saúde do consumidor, consumo sustentável, atendimento e suporte ao consumidor, resolução de problemas, reclamações e controvérsia, proteção e privacidade de dados do consumidor, educação e conscientização) (ASSSOCIAÇÃO BRASILEIRA DE NORMAS TÉCNICAS, 2012). Nessa dimensão não identificou-se relações fracas e nulas.

O diálogo com as partes interessadas apresentou relação moderada com a NBR 16001 considerando a média geral $(2,61)$. No entanto, essa temática pode ser inserida em vários requisitos da norma (3.3.1 Identificação das parte interessadas, 3.3.2 Temas centrais da responsabilidade social e suas questões, 3.4.2 Engajamento das partes interessadas e 3.4.3 Comunicação). Sendo assim, analisando pontualmente a Matriz de Relação Consolidada (apêndice 21) o requisito da sustentabilidade empresarial que aborda essa questão apresentou relação forte (valor médio $=9$ ) com 3 dos requisitos da NBR 16001 citados anteriormente.

Com relação a dimensão econômica - ambiental as temáticas que apresentaram relação forte com a NBR 16001 foram: gerenciamento de resíduos, políticas preventivas, qualidade ambiental, destinação final do produto, redução de consumo de recursos naturais, entre outros. Nessa dimensão não identificou-se relações nulas com a NBR 16001.

A dimensão ambiental - social - econômica apresentou relação forte com as seguintes temáticas: comunicação, postura ética, identificação e diálogo com as partes interessadas e monitoramento dos impactos das comunidades do entorno das empresas. Todas essas questões podem ser inseridas no requisito da NBR 16001 Temas centrais da responsabilidade social e suas questões (3.3.2).

O compromisso com o desenvolvimento sustentável apresentou relação moderada com a NBR 16001 considerando a média global (3). No entanto, essa temática está contemplada no requisito 3.2 Política da responsabilidade social da norma. Sendo assim, analisando a Matriz de Relação Consolidada (apêndice 23) observa-se que existe 
uma relação forte (valor médio $=6$ ) entre o requisito da sustentabilidade empresarial que aborda essa temática e o requisito 3.2 Política da responsabilidade social.

\subsection{OHSAS 18001:2007 - Sistema de gestão da segurança e saúde do trabalho - Requisitos.}

A seguir o quadro 15 apresenta um mapeamento do relacionamento da norma OHSAS 18001 com os requisitos da sustentabilidade que foram resumidos em temas centrais. Os resultados detalhados podem ser encontrados nos apêndices desse trabalho. As discussões estão baseadas em apenas algumas temática que foram consideradas mais relevantes.

Considerando a dimensão social as temáticas que apresentaram relação fraca com a OHSAS 18001 foram: tipos e taxas de lesões, doenças ocupacionais, dias perdidos, absenteísmo e número de óbitos relacionados ao trabalho. No entanto, o estudo realizado por Fernández-Muñiz; Montes-Peón e Vázquez-Ordás (2009) que teve como objetivo identificar boas práticas na gestão da segurança e analisar o efeito dessas práticas sobre um conjunto de indicadores de desempenho organizacional (ex. lesões pessoais, danos materiais, motivação dos colaboradores, satisfação do cliente, produtividade, qualidade do produto, entre outros) aponta que a implementação de um sistema de gestão da segurança e saúde do trabalho pode reduzir as taxas de acidentes, lesões pessoais, melhora as condições de trabalho, aumenta a motivação dos funcionários, reduz o absenteísmo, melhora da imagem e reputação empresarial, influência positiva na produtividade e inovação e influência positivamente sobre vendas, lucros e rentabilidade da empresa. 


\begin{tabular}{|c|c|c|c|c|}
\hline & Forte & Moderada & Relação fraca & Relação nula \\
\hline 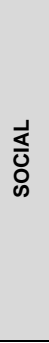 & & $\begin{array}{l}4 . \\
\text { Engajamento } \\
\text { das partes } \\
\text { interessadas } \\
\text { (Ethos, } \\
\text { (2013) e (ISE, } \\
\text { 2013). }\end{array}$ & $\begin{array}{l}\text { 1. Políticas de engajamento e diálogo com } \\
\text { as partes interessadas (Ethos, 2013) e (ISE, } \\
\text { 2013). } \\
\text { 3. Responsabilidade social na cadeia de } \\
\text { fornecimento (Ethos, 2013) e (ISE, 2013). } \\
\text { 8. Princípios éticos (Ethos, 2013). } \\
\text { 9. Direitos humanos (GRI). } \\
\text { 10. Planejamento de carreira dos } \\
\text { funcionários (Ethos, 2013). } \\
\text { 14. Doenças ocupacionais e acidentes de } \\
\text { trabalho (GRI). }\end{array}$ & $\begin{array}{l}\text { 2. Valorizar a diversidade, equidade e não discriminação (Ethos, 2013), (ISE, } \\
\text { 2013) e (GRI). } \\
\text { 5. Participação de políticas públicas (Ethos, 2013), (ISE, 2013) e (GRI). } \\
\text { 6. Patrocínio de programas e campanhas (Ethos, 2013), (ISE, 2013) e (GRI). } \\
\text { 7. Grupos vulneráveis (Ethos, 2013). } \\
\text { 11. Preparação interna dos funcionários (Ethos, 2013). } \\
\text { 12. Contratação de moradores locais (Ethos, 2013) e (ISE, 2013). } \\
\text { 13. Contratação de pessoas com deficiência (Ethos, 2013). } \\
\text { 15. Acordo entre empresas e sindicatos (GRI). }\end{array}$ \\
\hline 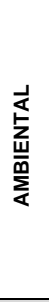 & & & $\begin{array}{l}\text { 24. Plano de emergência (Ethos, 2013). } \\
\text { 25. Monitoramento de riscos e dos aspectos } \\
\text { ambientais (Ethos, 2013). } \\
\text { 26. Plano de ação (Ethos, 2013). }\end{array}$ & $\begin{array}{l}\text { 16. Áreas de Preservação Permanente (APP) (ISE, 2013). } \\
\text { 17. Reserva Legal (ISE, 2013). } \\
\text { 18. Licenciamento ambiental (ISE, 2013). } \\
\text { 19. Mudanças climáticas (ISE, 2013). } \\
\text { 20. Política ambiental (Ethos, 2013) e (ISE, 2013). } \\
\text { 21. Preservação da biodiversidade (Ethos, 2013) e (ISE, 2013). } \\
\text { 22. Área ou comitê responsável pelo meio ambiente (Ethos, 2013). } \\
\text { 23. Estudo de impacto ambiental (Ethos, 2013). } \\
\text { 27. Efeito estufa (Ethos, 2013). } \\
\text { 28. Recursos renováveis (ISE, 2013). }\end{array}$ \\
\hline 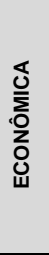 & & & $\begin{array}{l}\text { 29. Ativos intangíveis (ISE, 2013). } \\
\text { 30. Defesa de concorrência (ISE, 2013). } \\
\text { 35. Gestão de desempenho (ISE, 2013). }\end{array}$ & $\begin{array}{l}\text { 31. Gestão de riscos corporativos (ISE, 2013). } \\
\text { 32. Instrumentos financeiros derivativos (ISE, 2013). } \\
\text { 33. Monitoramento de impactos econômicos indiretos (ISE, 2013). } \\
\text { 34. Gestão de ativos intangívesis (ISE, 2013). } \\
\text { 36. Defesa de concorrência (ISE, 2013). } \\
\text { 37. Demonstrações financeiras em moeda constante (ISE, 2013) } \\
\text { 38. Geração de valor econômico (ISE, 2013). } \\
\text { 39. Valor econômico direto (receitas) (GRI). } \\
\text { 40. Plano de benefício (GRI). }\end{array}$ \\
\hline 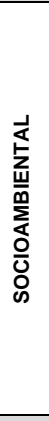 & & & $\begin{array}{l}\text { 41. Comprometimento da alta direção com } \\
\text { as questôes socioambientais (Ethos, 2013). } \\
\text { 44. Responsabilidade socioambiental na } \\
\text { cadeia produtiva (Ethos, 2013), (ISE, 2013) e } \\
\text { (GRI). } \\
\text { 45. Avaliação de fornecedores (Ethos, 2013), } \\
\text { (ISE, 2013) e (GRI). } \\
\text { 46. Elaboração de relatório socioambiental } \\
\text { (Ethos, 2013). } \\
\text { 47. Treinamento de fornecedores a respeito } \\
\text { de questốes socioambientais (Ethos, 2013) e } \\
\text { (ISE, 2013). }\end{array}$ & $\begin{array}{l}\text { 42. Incorporação de critérios socioambiental na estratégia da organização (Ethos, } \\
\text { 2013). } \\
\text { 43. Comunicação de aspectos socioambientais as partes interessadas (Ethos, } \\
\text { 2013). } \\
\text { 48. Participação de comitê/conselhos locais e/ou regionais (Ethos, 2013). } \\
\text { 49. Apoiar projetos educacionais (Ethos, 2013). } \\
\text { 50. Suporte técnico (ISE, 2013). } \\
\text { 51. Fornecimento de informações (Ethos, 2013). } \\
\text { 52. Divulgação dos aspectos e impactos ambientais (ISE, 2013). } \\
\text { 53. Mecanismos de Queixas e Reclamações Relativas a Impactos Ambientais } \\
\text { (ISE, 2013) }\end{array}$ \\
\hline 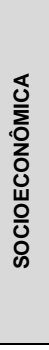 & & & $\begin{array}{l}\text { 54. Política de saúde e segurança } \\
\text { ocupacional (Ethos, 2013) e (ISE, 2013). } \\
\text { 55. Elaboração políticas trabalhistas, } \\
\text { remuneração, benefícios e carreira (Ethos, } \\
\text { 2013), (ISE, 2013) e (GRI, 2111). } \\
\text { 57. Condiçoes de trabalho (Ethos, 2013) e } \\
\text { (ISE, 2013). } \\
\text { 58. Diálogo com as partes interessadas } \\
\text { (Ethos, 2013), (ISE, 2013) e (GRI). } \\
\text { 60. Mapeamento de competências (Ethos, } \\
\text { 2013). } \\
\text { 61. Identificação empregados com alta } \\
\text { incidência ou alto risco de doenças } \\
\text { relacionadas à sua ocupaçâo (GRI) }\end{array}$ & $\begin{array}{l}\text { 56. Políticas relacionadas aos clientes (Ethos, 2013), (ISE, 2013) e (GRI). } \\
\text { 59. Inclusão de fornecedores locais (Ethos, 2013) (ISE, 2013) e (GRI). } \\
\text { 62. Defesa de concorrência (ISE, 2013). } \\
\text { 63. Distinção de gênero (GRI). }\end{array}$ \\
\hline 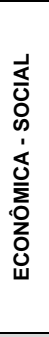 & & $\begin{array}{l}\text { 67. Políticas } \\
\text { preventivas } \\
\text { (Ethos, } \\
\text { 2013). }\end{array}$ & $\begin{array}{l}\text { 65. Gerenciamento de resíduos (Ethos, } \\
\text { 2013). }\end{array}$ & $\begin{array}{l}\text { 64. Melhoramento ambiental (Ethos, 2013) } \\
\text { 66. Monitoramento de insumos madeireiros (Ethos, 2013). } \\
\text { 68. Qualidade ambienta (Ethos, 2013). } \\
\text { 69. Destinaçãa final do produto (Ethos, 2013). } \\
\text { 70. Redução de consumo de recursos naturais (Ethos, 2013). } \\
\text { 71. Passivos ambientais (ISE, 2013). } \\
\text { 72. Degradação ambiental (ISE, 2013). } \\
\text { 73. Ciclo de vida do produto (ISE, 2013). } \\
\text { 74. Monitoramento dos aspectos ambientais significativos (Ethos, 2013), (ISE, } \\
\text { 2013). } \\
\text { 75. Consumo de recursos naturais na cadeia produtiva (ISE, 2013). } \\
\text { 76. “Ecodesign" ou DfE (Desing for Environment) (ISE, 2013). } \\
\text { 77. Planejamento do produto (ISE, 2013). }\end{array}$ \\
\hline 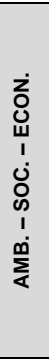 & & & & $\begin{array}{l}\text { 78. Política de comunicação (Ethos, 2013) } \\
\text { 79. Postura ética (Ethos, 2013). } \\
\text { 80. Identificação das partes interessadas (Ethos, 2013) e (ISE, 2013). } \\
\text { 81. Diálogo com as partes interessadas (Ethos, 2013) (ISE, 2013) e (GRI). } \\
\text { 82. Monitoramento dos impactos das comunidades do entorno (Ethos, 2013). } \\
\text { 83. Responsável por garantir a ética interna e externamente a organização (Ethos, } \\
\text { 2013) e (ISE, 2013). } \\
\text { 84. Não atuação na concorrência desleal (Ethos, 2013) e (GRI). } \\
\text { 85. Cumprimento das legislações (Ethos, 2013) e (ISE, 2013). } \\
\text { 86. Compromisso com o desenvolvimento sustentável (ISE, 2013). } \\
\text { 87. Definição de responsabilidade e autoridades (ISE, 2013). } \\
\text { 88. Gestão de oportunidade corporativa (ISE, 2013). } \\
\text { 89. Plano de contigência (ISE, 2013). }\end{array}$ \\
\hline
\end{tabular}

Quadro 15. Relacionamento entre a OHSAS 18001 e os requisitos da sustentabilidade empresarial. 
Analisando a dimensão ambiental uma das temáticas que teve relação fraca com a OHSAS 18001 está relacionado com monitoramento de riscos e dos aspectos ambientais. A ocorrência de acidentes ambientais podem gerar danos a segurança e saúde dos colaboradores e terceirizados. Nessa dimensão não identificou-se relações fortes ou moderadas.

Considerando a dimensão econômica observa-se que a OHSAS 18001 não apresentou relação forte nem moderada com nenhum dos requisitos da sustentabilidade empresarial inseridas nessa dimensão. Isso se deve pelo fato da OHSAS não considerar questões econômicas específicas.

Analisando a dimensão socioambiental observa-se que a OHSAS 18001 não apresentou relação forte nem moderada com nenhum dos requisitos da sustentabilidade empresarial inseridas nessa dimensão. Isso aconteceu pelo fato da OHSAS 18001 não considerar diretamente questões ambientais.

Com relação a dimensão socioeconômica as temáticas como política de saúde e segurança ocupacional, condições de trabalho e monitoramento de riscos apresentaram relação fraca com a OHSAS 18001. No entanto, analisando a Matriz de Relação Validada (apêndice 28) é possível identificar que essas temáticas apresentaram relações fortes com os seguintes requisitos da sustentabilidade respectivamente: 4.2 Política de Segurança e saúde no trabalho (valor médio = 9), 4.4.6 Controle operacional (valor médio =9) e 4.3.1 Identificação de perigos, avaliação de riscos e determinação de medidas de controle (valor médio $=9$ ).

A dimensão econômica - ambiental apresentou relação nula com praticamente todas as temáticas envolvidas na sustentabilidade. Com relação a dimensão ambiental social - econômica é possível observar que todas as relações existentes foram nulas apontando que a OHSAS 18001 representa apenas uma contribuição que se enquadra no pilar social da sustentabilidade. 


\section{Gapíula 5}

\section{CONCLUSÕES}

Este trabalho teve como objetivo analisar a relação entre normas de sistemas de gestão (ISO 9001, ISO 14001, OHSAS 18001 e NBR 16001) e a sustentabilidade empresarial. Para alcançar esse objetivo foi realizado uma revisão bibliográfica exploratória a respesito das temáticas a fim de encontrar as lacunas de pesquisa. Diante desse contexto, não identificou-se estudo que apontassem a relação entre as normas de sistema de gestão ISO 9001, ISO 14001, OHSAS 18001 e NBR 16001 com a sustentabilidade empresarial. Essas normas de sistema de gestão foram selecionadas pelo fato de serem amplamente aceita no mundo, com exceção da NBR 16001 que é um padrão normativo brasileiro certificável e que foi selecionado por fazer parte da coletânea de normas que auxiliam as empresas no suporte a sustentabilidade empresarial. Os requisitos da sustentabilidade empresarial foram identificados considerando o princípio de materialidade apresentado no GRI. Sendo assim, extraiu-se esses requisitos do GRI, do Índice de Sustentabilidade Empresarial e dos Indicadores Ethos. Posteriormente foi estabelecido uma escala de relação (forte, fraca e nula) onde especialistas foram consultados para auxiliarem no preenchimento da Matriz de Relação.

Analisando as matrizes de relacionamento foi possível concluir que a ISO 9001 apresenta relação fraca com a sustentabilidade corporativa. Isso aconteceu pelo fato da ISO 9001 não abordar diretamente questões econômicas, sociais e ambientais. Sendo assim, é possível concluir que a ISO 9001 é uma ferramenta que pode ser utilizada para ajudar as empresas a serem sustentáveis, no entanto sua utilização sozinha não garantirá a sustentabilidade empresarial. A ISO 14001 apresentou relação moderada com a sustentabilidade corporativa, pelo fato de que esse padrão não considera diretamente as questões econômicas e sociais. Sendo assim, é possível concluir que a ISO 14001 é uma ferramenta que pode ser utilizada para ajudar as empresas a serem sustentáveis, no entanto, sua utilização sozinha não garantirá a sustentabilidade empresarial.

Analisando a matriz de relacionamento consolidada a NBR 16001 apresentou relação forte com a sustentabilidade empresarial. No entanto, essa norma é que possui menor aceitação pelas empresas, talvez pelo fato da questão da responsabilidade social ser uma temática que está começando a ser inserida nas organizações de maneira 
sistemática. As dimensões que apresentaram médias globais enquadrando-se na relação forte foram: dimensão ambiental, socioeconômico, econômica - ambiental e social ambiental - econômica. Esse padrão normativo apresentou relação forte com a sustentabilidade empresarial pelo fato de considerar questões ambientais, sociais e econômicas. Diante desse contexto, o pressuposto assumido no início da pesquisa de que a NBR 16001 representa o pilar social é aceitável. Além disso, foi possível observar que esse padrão também representa o pilar ambiental.

A OHSAS 18001 apresentou relação fraca com a sustentabilidade corporativa. Os requisitos da sustentabilidade empresarial inseridos na dimensão ambiental - social econômica apresentaram todas as relação nulas com os requisitos desse padrão. Isso ocorreu pelo fato desse padrão não considerar diretamente questões econômicas e ambientais. Sendo assim, é possível concluir que a OHSAS 18001 é uma norma que pode ser utilizada para ajudar as empresas a serem sustentáveis, no entanto sua utilização sozinha não garantirá a sustentabilidade empresarial, já que essa representa apenas algumas características presentes no pilar social.

É importante frisar que o estudo apresenta algumas limitações sendo elas:

Os resultados foram interpretados considerando as médias gerais e globais, ou seja, analisamos as normas como um todo como o método propõe;

> Não foi possível identificar os requisitos da sustentabilidade empresarial detalhadamente, pois inviabilizaria a pesquisa, por isso consideramos o princípio de materialidade do GRI;

$>$ O número de especialistas consultados poderia ter sido maior;

$>$ Outras normas poderiam ter sido inseridas no escopo da pesquisa, no entanto, o tempo foi um limitante.

As sugestões para realização de trabalhos futuros são:

$>$ Aumentar o número de especialistas consultados para analisar-se estatisticamente;

> Inserir outras normas no estudo que fazem parte da coletânea da ABNT para a sustentabilidade como ISO 14062:2004 (Gestão ambiental - Integração de aspectos ambientais no projeto e desenvolvimento do produto), ISO 14040:2009 (Gestão ambiental - Avaliação do ciclo de vida - Princípios e estrutura), ISO 
14044:2009 (Gestão ambiental - Avaliação do ciclo de vida - Requisitos e orientações), ISO 9004:2008 (Gestão para o sucesso sustentado de uma organização - uma abordagem da gestão da qualidade), ISO 10002:2010 (Gestão da qualidade - Satisfação do cliente - Diretrizes para o tratamento de reclamações nas organizações), ISO 10014:2008 (Custos da Qualidade - Gestão de aspectos econômicos da qualidade), ISO 31000:2009 (Gestão de riscos Princípios e diretrizes), ISO 50001:2011 (Sistemas de gestão da energia Requisitos com orientações para uso), NBR 18801:2010 (Sistema de gestão da segurança e saúde no trabalho — Requisitos) e ISO 26000:2010 (Diretrizes em responsabilidade social); e

Atualizar a pesquisa considerando a revisão que as normas ISO 9001, ISO 14001 e OHSAS 18001 estão passando até a data de conclusão desta pesquisa (julho/2015).

As recomendações para gestores que desejam implementar esses sistemas de gestão para inserir a sustentabilidade em seus contextos são as seguintes:

> A ISO 9001 provavelmente não auxiliará diretamente ao alcance desse objetivo. No entanto, a implementação de um sistema de gestão da qualidade baseado nesse padrão normativo poderá assegura um dos elementos que compõe a sustentabilidade empresarial que está relacionada a entrega de produtos de qualidade para os clientes. Esse padrão sozinho não representa a dimensão econômica. Os benefícios econômicos gerados podem ser uma consequência da implementação desse sistema;

> A OHSAS 18001 é um padrão normativo que abrange apenas um elementos da sustentabilidade empresarial que está relacionado a garantia da saúde e segurança dos trabalhadores e terceiros no ambiente de trabalho. Sendo assim, sozinho não representa o pilar social. No entanto, ao implementar um sistema de segurança e saúde ocupacional as empresas estarão caminhando em direção a sustentabilidade, sendo assim, recomenda-se implementar esse sistema de gestão;

$>$ De acordo com o presente estudo a ISO 14001 possui uma relação forte com os assuntos relacionados ao atendimento de requisitos legais aplicáveis, introduz a questão da prevenção da poluição em seu escopo, auxilia na identificação de aspectos e impactos ambientais significativos, entres outros. Sendo assim, esse 
padrão normativo representa a dimensão ambiental, ou seja, empresas que implementarem o sistema de gestão ambiental baseados nesse padrão poderão inserir essas temáticas em seus contextos. Sendo assim, recomenda-se a implementação desse sistema. Diante desse contexto, a ISO 14001 utilizada sozinha não garante a inserção da sustentabilidade nos ambientes corporativos, já que não aborda questões sociais e econômicas;

Com relação a NBR 16001 o presente estudo aponta que esse padrão normativo foi o que mais apresentou os elementos da sustentabilidade empresarial. Sendo assim, recomenda-se a utilização desse padrão normativo como uma forma que as empresas possuem em inserir as questões sociais, ambientais e econômicas em seus contextos.

As recomendação destinadas a participantes de comitês de revisão dos padrões normativos estudados:

A ISO 14001, ISO 9001 e OHSAS 18001 poderiam incluir em seus escopos a necessidade de identificar as partes interessas, manter o diágolo e engajamento com as mesmas, além de indicar a necessidade das empresas monitorarem seus impactos (ambiental, social e econômico) considerando todas as partes interessadas. Com relação a NBR 16001 recomenda-se a inserção de elementos da sustentabilidade relacionados a dimensão econômica (ex. gestão de riscos corporativos) e um elaboração de requisitos mais detalhados e claros. 


\section{REFERÊNCIAS}

ALIC, M. Impact of ISO 9001 certification cancellation on business performance: a case study in Slovenian organisations. Total Quality Management \& Business Excellence, v. 25, n. 7-8, p. 790-811, 2014.

ALLUR, E.; HERAS-SAIZARBITORIA, I.; CASADESUS, M. Internalization of ISO 9001: a longitudinal survey. Industrial Management \& Data Systems, v. 114, n. 6, p. 872-885, 2014.

AMARAL, S. P. Sustentabilidade ambiental, social e econômica: como entender, medir e relatar. 2. ed. São Paulo: Tocalino, 2005. 124 p.

ARIMURA, T. H.; DARNALL, N.; KATAYAMA, H. Is ISO 14001 a gateway to more advanced voluntary action? The case of green supply chain management. Journal of Environmental Economics and Management, v. 61, n. 2, p. 170-182, 2011.

ASSOCIAÇÃO BRASILEIRA DE NORMAS TÉCNICAS. ABNT NBR 16001:2012. Rio de Janeiro: Associação Brasileira de Normas Técnicas, 2012a. 48p.

ASSOCIAÇÃO BRASILEIRA DE NORMAS TÉCNICAS. ABNT NBR ISO 10014:2008. Rio de Janeiro: Associação Brasileira de Normas Técnicas, 2008b. 32p.

ASSOCIAÇÃO BRASILEIRA DE NORMAS TÉCNICAS. ABNT NBR ISO 14001:2004. Rio de Janeiro: Associação Brasileira de Normas Técnicas, 2004. 27p.

ASSOCIAÇÃO BRASILEIRA DE NORMAS TÉCNICAS. ABNT NBR ISO 26000:2010. Rio de Janeiro: Associação Brasileira de Normas Técnicas, 2010b. 112p.

ASSOCIAÇÃO BRASILEIRA DE NORMAS TÉCNICAS. ABNT NBR ISO 9000:2005. Rio de Janeiro: Associação Brasileira de Normas Técnicas, 2005. 42p.

ASSOCIAÇÃO BRASILEIRA DE NORMAS TÉCNICAS. ABNT NBR ISO 9001:2008. Rio de Janeiro: Associação Brasileira de Normas Técnicas, 2008a. 28p.

ASSOCIAÇÃO BRASILEIRA DE NORMAS TÉCNICAS. ABNT NBR ISO 9004:2010. Rio de Janeiro: Associação Brasileira de Normas Técnicas, 2010a. 47.

ASSOCIAÇÃO BRASILEIRA DE NORMAS TÉCNICAS. Coletânea de normas técnicas: Gestão para suporte a sustentabilidade. Rio de Janeiro: Associação Brasileira de Normas Técnicas, 2012b. 573p.

BABAKRI, K.A.; BENNETT, R.A.; FRANCHETTI, M. Critical factors for implementing ISO 14001 standard in United States industrial companies. Journal of Cleaner Production, v. 11, n. 7, p. 749-752, 2003.

BANSAL, P.; BOGNER, W. C. Deciding on ISO 14001: Economics, institutions, and context. Long Range Planning, v. 35, n. 3, p. 269-290, 2002. 
BANSAL, P.; HUNTER, T. Strategic explanations for the early adoption of ISO 14001. Journal of Business Ethics, v. 46, n. 3, p. 289-299, 2003.

BARBIERI, J. C. Gestão Ambiental Empresarial: conceitos, modelos e instrumentos. São Paulo: 2011. 358p.

BARBIERI, J.C.; CAJAZEIRA, J. E. R. Responsabilidade social empresarial e empresa sustentável: da teoria à prática. São Paulo: Editora Saraiva, 2009.

BARLA, P. ISO 14001 certification and environmental performance in Quebec's pulp and paper industry. Journal of Environmental Economics and Management, v. 53, n. 3, p. 291-306, 2007.

BAUMGARTNER, R. J.; EBNER, D. Corporate Sustainability Strategies: Sustainability Profiles and Maturity Levels. Sustainable Development, v. 18, n. 2, p. 76-89, 2010.

BOIRAL, O. Corporate greening through ISO 14001: A rational myth? Organization Science, v. 18, n. 1, p. 127-146, 2007.

BOIRAL, O.; HENRI, J.F. Modelling the impact of ISO 14001 on environmental performance: A comparative approach. Journal of Environmental Management, v. 99, p. 84-97, 2012.

BOS-BROUWERS, H. E. J. Corporate Sustainability and Innovation in SMEs: Evidence of Themes and Activities in Practice. Business Strategy and the Environment, v. 19, n. 7, p. 417-435, 2010.

BOVESPA. Índice de Sustentabilidade Empresarial - ISE. 2014. Disponível em: $<$ http://www.bmfbovespa.com.br/indices/ResumoIndice.aspx?Indice=ISE\&idioma=ptbr>. Acesso em: 06 Nov. 2014.

BRASIL. Conferência das Nações Unidas sobre Desenvolvimento Sustentável: Brasil na Rio+20. 2011. Disponível em: < http://www.rio20.gov.br/sobre_a_rio_mais_20.html>. Acesso em: 07 Nov. 2014.

BRASIL. Constituição da República Federativa do Brasil - 1988. Acesso em: 03 jul. 2015. Disponível em: <http://www.planalto.gov.br/ccivil_03/constituicao/constituicaocompilado.htm>.

BRASIL. Decreto no 19.433, de 26 de Novembro de 1930. Acesso em: 03 jul. 2015. Disponível em: <http://www2.camara.leg.br/legin/fed/decret/1930-1939/decreto-1943326-novembro-1930-517354-publicacaooriginal-1-pe.html>.

BRASIL. Decreto-Lei no 5.452 aprova em 1943. Acesso em: 03 jul. 2015. Disponível em: < http://www.planalto.gov.br/ccivil_03/decreto-lei/Del5452.htm>.

BRASIL. DECRETO-LEI No 7.036 - DE 10 DE NOVEMBRO DE 1944. Acesso em: 4 jul. $2015 . \quad$ Disponível em: 
http://www3.dataprev.gov.br/sislex/paginas/23/1967/..\%5C..\%5C24\%5C1944\%5C7036 .htm>.

BRASIL. Lei 10.097/2000. Acesso em: 03 jul. 2015. Disponível em: < http://www.planalto.gov.br/Ccivil_03/LEIS/L10097.htm>.

BRASIL.Lei $\mathbf{n}^{\mathbf{0}}$ 5.161, de 21 de outubro de 1966. Acesso em: 03 jul. 2015. Disponível em: <http://www.planalto.gov.br/ccivil_03/leis/L5161.htm>.

BRASIL. Decreto-Lei no 2.848, de 7 de dezembro de 1940. Acesso em: 21 jul. 2015. Disponível em: < http://www.planalto.gov.br/ccivil_03/decreto-lei/Del2848.htm>.

BRITISH STANDARDS INSTITUTION. OHSAS 18001:2007. 2. ed. London: OHSAS Project Group, 2007. p. 22

BUREAU VERITAS. ISO 9001:2015 - Versão DIS publica. 2015. Acesso em: 03 jul. $2015 . \quad$ Disponível em: $<$ http://www.bureauveritascertification.com.br/novidades/noticias/iso-90012015$\%$ E2\%80\%93-versao-dis-publicada\#\&panel1-2>.

CAMPOS, V. F. TQC - Controle da Qualidade Total (no estilo japonês). INDG Tecnologia e Serviços Ltda: Nova Lima, 2004. 255p.

CARPINETTI, L.C.R. Gestão da qualidade: conceitos e técnicas. Atlas: São Paulo, 2012. 239p.

CARPINETTI, L.C.R; MIGUEL, P.A.C; GEROLAMO, M.C. Gestão da qualidade ISO 9001:2008: princípios e requisitos. São Paula: Atlas. 2011.

CARROLL, A. B. The pyramid of corporate social responsibility: Toward the moral management of organizational stakeholders. Business Horizons, v. 34, n. 4, p. 39-48, 1991.

CARROLL, A.B. Three-Dimensional Conceptual Model of Corporate Social Performance. Academy of Management Review, n. 4, v. 4, p. 497-505, 1979.

CERE. Coalition for Environmentally Responsible Economies. 2014. Disponível em: < http://www.ceres.org/about-us>. Acesso em: 05 Nov. 2014.

CERQUEIRA, J.P. Sistemas de gestão integrados: ISO 9001, ISO 14001, AS 8000 e NBR 16001. Conceitos e aplicações. Qualitimark: Rio de Janeiro, 2012. 517p.

CORDANI, U. G.; MARCOVITCH, J.; SALATI, E.. Avaliação das Ações Brasileiras apos a Rio-92 . Estudos Avançados. 1997, v.11, n.29, p. 399-408, 1997.

CROSBY, P. B. Qualidade é investimento. Rio de Janeiro: 1994. 327p.

DEPEXE, M. D.; PALADINI, E. P. Benefícios da implantação e certificação de sistemas de gestão da qualidade em empresas construtoras. Revista Gestão Industrial, v. 04, n. 02, p. 145-161, 2008. 
DOWELL, G.; HART, S.; YEUNG, B. Do corporate global environmental standards create or destroy market value? Management Science, v. 46, n. 8, p. 1059-1074, 2000.

DYLLICK, T. HOCKERTS, K. Beyond the business case for corporate sustainability. Business Strategy and the Environment, v. 11. n. 2, p.130-141, 2002.

ELKINGTON, J. Canibais com garfo e faca. São Paulo: Makron Books, 2001. 444p.

ETHOS. Indicadores Ethos de Responsabilidade Social Empresarial. São Paulo: Instituto Ethos, 2007.

ETHOS. Indicadores Ethos para Negócios Sustentáveis e Responsáveis. 2014. Disponível em: < http://www3.ethos.org.br/conteudo/gestao-socialmente-responsavel/>. Acesso em: 06 Nov. 2014.

EUROPEAN COMMISSION. Environmental: about EMAS. Disponível em: <http://ec.europa.eu/environment/emas/about/index_en.htm>. Acesso em: 05 Nov. 2014.

FALCONI, V. O verdadeiro poder: práticas de gestão que conduzem a resultados revolucionários. INDG Tecnologia e Serviços Ltda: Nova Lima, 2009. 159p.

FERNÁNDEZ-MUÑIZ， B.; MONTES-PEÓN， J.M.; VÁZQUEZ-ORDÁS， C.J. Relation between occupational safety management and firm performance. Safety Science. v. 47, p. 980 - 991. 2009.

FERREIRA-REBELO, M.; SANTOS, G.; SILVA, R. A generic model for integration of Quality, Environment and Safety Management Systems. The TQM Journal, v. 26, n. 2, p. 143-159, 2014.

FONSECA, L.M.C.M. ISO 14001:2015: An Improved Tool for Sustainability. Journal of Industrial Engineering and Management. v. 8, n. 1, p. 37-50, 2015.

FRIEDMAN, M. The Social Responsibility of Business is to Increase its Profits. The New York Times Company. 1970. Acesso em: 03 jul. 2015. Disponível em: < http://www.colorado.edu/studentgroups/libertarians/issues/friedman-soc-respbusiness.html>.

GARVIN, D. A. Gerenciando a qualidade: a visão estratégica e competitiva. Rio de Janeiro: 1992. 358p.

GLOBAL REPORTING INITIATIVE. Diretrizes para relato de sustentabilidade. 2013. 272p.

GONZALEZ-BENITO, J.; GONZALEZ-BENITO, O. Operations management practices linked to the adoption of ISO 14001: An empirical analysis of Spanish manufacturers. International Journal of Production Economics, v. 113, n. 1, p. 6073, 2008.

HART, S. L. Beyond greening: Strategies for a sustainable world. Harvard Business Review, v. 75, n. 1, p. 66-76, 1997.

HERAS-SAIZARBITORIA, I.; LANDIN, A.G.; MOLINA-AZORIN, F.J. Do drivers 
matter for the benefits of ISO 14001? International Journal of Operations \& Production Management, v. 31, n. 1-2, p. 192-215, 2011.

INMETRO. Programa Brasileiro de Certificação em Responsabilidade Social. 2015. Disponível em:

http://www.inmetro.gov.br/qualidade/responsabilidade_social/programa_certificacao.as p>. Acesso em: 13 Jul. 2015.

INSTITUTO BRASILEIRO DE GEOGRAFIA E ESTATISTICA. Indicadores de Desenvolvimento Sustentável. 2004. Acesso em: 4 jul. 2015. Disponível em: < http://www.ibge.gov.br/home/geociencias/recursosnaturais/ids/defaulttab.shtm>.

INTERNATIONAL INSTITUTE FOR SUSTAINABLE DEVELOPMENT. Business strategy for sustainable development: Leadership and accountability for the '90s. Canada: IISD, Deloitte and Touche with Business Council for Sustainable Development, 1992. 82p.

INTERNATIONAL LABOUR OFFICE. Safety and health in the use of chemicals at work. World Day for safety and health at work 28 April 2014.

INTERNATIONAL ORGANIZATION FOR STANDARDIZATION. The ISO Survey of Management System Standard Certifications - 2014. Disponível em: < http://www.iso.org/iso/home/standards/certification/iso-survey.htm >. Acesso em: 18 Nov. 2014.

INTERNATIONAL STANDARDS ORGANIZATION. First draft of ISO's occupational health and safety standard now available. 2015. Acesso em: 3 jul. 2015. Disponível em: < http://www.iso.org/iso/news.htm?refid=Ref1874>.

JAPPUR, R. F. A sustentabilidade corporativa frente às diversas formações de cadeias produtivas segundo a percepção de especialistas. 2004. 161 f. Dissertação (Mestrado em Engenharia de Produção) - Programa de Pós-Graduação em Engenharia de Produção, Universidade Federal de Santa Catarina, Florianópolis, 2004.

JIANG, R. H. J.; BANSAL, P. Seeing the need for ISO 14001. Journal of Management Studies, v. 40, n. 4, p. 1047-1067, 2003.

JURAN, J.M.; GRYNA, F.M. Quality planning and analysis: from product development through use. 3 ed. New York: McGraw-Hill, 1993. 634 p

KAUSEK, J. OHSAS 18001 Designing an implementing an effective health and safety management system. Lanham, Maryland: The Rowman and Littlefield Publishing Group. 162 p.

KING, A.A.; LENOX, M.J. Does It Really Pay to Be Green? An Empirical Study of Firm Environmental and Financial Performance: An Empirical Study of Firm Environmental and Financial Performance. Journal of Industrial Ecology, v. 5, n. 1, p.105-116, 2001. 
LEBEAU. M.; DUGUAY, P. The Costs of Occupational Injuries: A Review of the Literature. The Institut de recherche Robert-Sauvé en santé et en sécurité du travail (IRSST). 2013.

LINNENLUECKE, M. K.; GRIFFITHS, A. Corporate sustainability and organizational culture. Journal of World Business, v. 45, n. 4, p. 357-366, 2010.

MARREWIJK, M. Concepts and definitions of CSR and corporate sustainability: Between agency and communion. Journal of Business Ethics, v. 44, n. 2, p. 95-105, 2003.

MARREWIJK, V.M.; WERRE, M. Multiple levels of corporate sustainability. Journal of Business Ethics, v. 44, n. 2, p. 107-119, 2003.

MASSACHUSETTS INSTITUTE OF TECHNOLOGY. The Innovation Bottom Line: How Companies that see sustainability as both a necessity and an opportunity, and change their business models in response, are finding success. Research Report, 2013.

MEADOWS et al. The limits to growth. New York: Universe Book. 205p. 1972.

MELLO, M.B.F.V. Influência da cultura organizacional no sistema de gestão da segurança e saúde no trabalho em empresas construtoras. $180 \mathrm{p}$. Tese (doutorado). Universidade Federal de Santa Catarina. Santa Catarina, 2001.

MELO-NETO, F.P.; FROES, C. Gestão da responsabilidade social corporativa: o caso brasileiro. Rio de Janeiro: Qualitymark, 2001. 189p.

MIL. Quality program reqirements. MIL-Q-9858A. 1959.

MINISTÉRIO DO TRABALHO E EMPREGO. A história do Ministério do Trabalho e Emprego. 2015. Acesso em: 03 jul. 2015. Disponível em: <http://www2.mte.gov.br/institucional/historia.asp>.

MINISTÉRIO DO TRABALHO E EMPREGO. Manual de combate ao trabalho em condições análogas às de escravo. 2011.

MORAES, M.C.P.; BENEDICTO, G.C.; CALIL, J.F.; MOREIRA, C.A.A. Análise da relevância da ética na prática empresarial. 123-134p. In: CALIL, J.F.; BENEDICTO, G.C.; SILVA-FILHO, C.F. Ética, responsabilidade social e governança corporativa. Campinas: Alínea, 2008. 218p.

MUNIZ,F. B.; PEON, J.M.M.; ORDAS, C.J.V. Occupational risk management under the OHSAS 18001 standard: analysis of perceptions and attitudes of certified firms. Journal of Cleaner Production, v. 24, p. 36-47, 2012.

NAÇÕES UNIDAS. Do Rio à Rio+20: Progresso e desafio desde a Cúpula da Terra de 1992. Rio de Janeiro, 2012.

NAWROCKA, D.; BRORSON, T.; LINDHQVIST, T. ISO 14001 in environmental supply chain practices. Journal of Cleaner Production, v. 17, n. 16, p. 1435-1443, 2009. 
NETO, A. S.; CAMPOS, L. D. S.; SHIGUNOV, T. Fundamentos da gestão ambiental. Rio de Janeiro: Ciência Moderna, 2009. 318p.

NETO, J.B.M.R.; TAVARES, J. da C.; HOFFMANN, S.C. (2013). Sistema de Gestão Integrado: qualidade, meio ambiente, responsabilidade social e segurança e saúde no trabalho. São Paulo: Editora Senac, 342 p.

NISHITANI, K. An empirical study of the initial adoption of ISO 14001 in Japanese manufacturing firms. Ecological Economics, v. 68, n. 3, p. 669-679, 2009.

OLIVEIRA, R.M.R. A abordagem das lesões por esforços repetitivos/distúrbios osteomoleculares relacionados ao trabalho - LER/DORT no Centro de Referência em Saúde do Trabalhador do Espírito Santo - CRST/ES. [Mestrado] Fundação Oswaldo Cruz, Escola Nacional de Saúde Pública; 2001. 143 p.

ORGANIZAÇÃO DAS NAÇÕES UNIDAS. Programa das Nações Unidas para o Meio Ambiente. 2014a. Disponível em: <http://www.onu.org.br/onu-nobrasil/pnuma/>. Acesso em 05 Nov. 2014.

ORGANIZAÇÃO DAS NAÇÕES UNIDAS. A ONU e o Meio Ambiente. 2014b. Disponível em: < http://www.onu.org.br/a-onu-em-acao/a-onu-e-o-meio-ambiente/>. Acesso em: 05 Nov. 2014.

ORGANIZAÇÃO DAS NAÇÕES UNIDAS. Declaração dos Direitos Humanos. 1948.

ORGANIZAÇÃO DAS NAÇÕES UNIDAS. Luzes sobre a Rio+20: o que aconteceu desde 1992. 2012. Disponível em: < http://www.onu.org.br/rio20/tema/rio-92/>. Acesso em: 05 Nov. 2014.

ORGANIZAÇÃO DAS NAÇÕES UNIDAS. Pacto Internacional dos Direitos Civis e Políticos. 1996a.

ORGANIZAÇÃO DAS NAÇÕES UNIDAS. Pacto Internacional sobre os Direitos Econômicos, Sociais e Culturais. 1996b.

ORGANIZAÇÃO DAS NAÇÕES UNIDAS. Programa das Nações Unidas para o Meio Ambiente. 2014a. Disponível em: <http://www.onu.org.br/onu-nobrasil/pnuma/>. Acesso em 05 Nov. 2014.

ORGANIZAÇÃO INTERNACIONAL DO TRABALHO. A prevenção das doenças profissionais: 2 milhoes de trabalhadores morre por ano. 2013a.

ORGANIZAÇÃO INTERNACIONAL DO TRABALHO. Combate ao trabalho infantil. 52p. 2001.

ORGANIZAÇÃO INTERNACIONAL DO TRABALHO. Declaração da OIT sobre os princípios e direitos fundamentais no trabalho. 1998. 
ORGANIZAÇÃO INTERNACIONAL DO TRABALHO. História. 2015. Acesso em: 03 jul. 2015. Disponível em: <http://www.oitbrasil.org.br/content/hist\%C3\%B3ria>.

ORGANIZAÇÃO INTERNACIONAL DO TRABALHO. Medir o progresso na Luta contra o Trabalho Infantil: Estimativas e tendências mundiais 2000-2012. 2013b.

ORGANIZAÇÃO INTERNACIONAL DO TRABALHO. Questionando um mito: custos do trabalho de homens e mulheres / Laís Abramo (ed.); Organização Internacional do Trabalho - Brasília : OIT , 2005. 196 p.

ORGANIZAÇÃO INTERNACIONAL DO TRABALHO. Trabalho forçado ou obrigatório. 1930. Acesso em: 21 jul. 2015. Disponível em: < http://www.oitbrasil.org.br/node/449>.

PALADINI, E. P. Gestão da qualidade: teoria e práticas. São Paulo: 2004. 339p.

PENIDO, A.M.S.; RODRIGES, A.C.; BENEDICTO, S.C.; DIAS, W.P. Surgimento e evolução da responsabilidade social empresarial: uma reflexão teórico analítica 63-82p. In: CALIL, J.F.; BENEDICTO, G.C.; SILVA-FILHO, C.F. Ética, responsabilidade social e governança corporativa. Campinas: Alínea, 2008. 218p.

PIMENTA, H.C.D. (2010). Sustentabilidade empresarial: práticas em cadeias produtivas. Natal: IFRN Editora, 2010.

POLTRONIERI, C.F. Avaliação do grau de maturidade dos Sistemas de Gestão Integrados (SGI). 2014. 116p. Dissertação (Mestrado) - Escola de Engenharia de São Carlos, Universidade de São Paulo, São Carlos, 2014.

PRAKASH, A.; POTOSKI, M. Racing to the bottom? Trade, environmental governance, and ISO 14001. American Journal of Political Science, v. 50, n. 2, p. 350-364, 2006.

Investing up: FDI and the cross-country diffusion of ISO 14001 management systems. International Studies Quarterly, v. 51, n. 3, p. 723-744, 2007.

PROGRAMA DAS NAÇÕES UNIDAS PARA O DESENVOLVIMENTO. Os Objetivos de Desenvolvimento do Milênio: 8 objetivos para 2015. 2012. Disponível em: < http://www.pnud.org.br/ODM.aspx>. Acesso em: 05 Nov. 2014.

QI, G. et al. ISO and OHSAS certifications How stakeholders affect corporate decisions on sustainability. Management Decision, v. 51, n. 10, p. 1983-2005, 2013.

REINHARDT, F. Market Failure and the Environmental Policies of Firms: Economic Rationales for "Beyond Compliance" Behavior. Journal of Industrial Ecology, v. 3, n. 1, p. 9-21, 1999.

RESPONSIBLE CARE. A Brief History of Responsible Care: a Vision Born in Canada That's Leading the World. 2014. Disponível em: <http://www.canadianchemistry.ca/responsible_care/index.php/en/responsible-carehistory>. Acesso em: 05 de Nov. 2014.

REVISTA PROTEÇÃO. Anuário Brasileiro de Proteção 2014. Disponível em: < http://www.protecao.com.br/conteudo/anuario_brasileiro_de_p_r_o_t_e_c_a_o/anuario 
_2014/JajbAJ_JyjgAJ>. Acesso em: Acesso em: 23 Out. 2014.

ROCHA, M.; SEARCY, C.; KARAPETROVIC, S. Integrating Sustainable Development into Existing Management Systems. Total Quality Management, v. 18, p. 83-92, 2007.

SACHS, Ignacy. Caminhos para o desenvolvimento sustentável. 3. ed. Rio de Janeiro: Garamond, 2002.

SACHS, Ignacy. Estratégia de Transição para o Século XXI. São Paulo: Nobel, 1993.

SAVITZ, A. W.; WEBER, K. A empresa sustentável: o verdadeiro sucesso é o lucro com responsabilidade social e ambiental. Rio de Janeiro: Elsevier, 2007. 304 p.

SCHWARTZ, M.; CARROLL, A. Corporate Social Responsibility: a three-domain approach. Business Ethics Quarterly, v. 13, I.4, p. 503-530, 2003.

SEIFFERT, M. E. B.. Sistemas de gestão ambiental (ISO 14001) e saúde e segurança ocupacional (OHSAS 18001) vantagens da implantação integrada. São Paulo: Atlas, 2010. 201p.

SHEWART, W.A. Economic Control of Quality of Manufactured Product. D. Van Nostrand Company Inc.: Toronto, New York and London, 1981. 506p.

SIMON, A.; KARAPETROVIC, S.; CASADESUS, M. Difficulties and benefits of integrated management systems. Industrial Management \& Data Systems, v. 112, n. 5-6, p. 828-846, 2012.

SORATTO et al. Sistema da gestão da responsabilidade social: desafios para a certificação nbr 16001. Revista Gestão Industrial. v. 2, n. 4, p. 13-25, 2006.

STRONG, M. F. Eco 92 - critical challenges and global-solutions. Journal of International Affairs, v. 44, n. 2, p. 287-300,1991.

TAN, L. P. Implementing ISO 14001: is it beneficial for firms in newly industrialized Malaysia? Journal of Cleaner Production, v. 13, n. 4, p. 397-404, 2005.

TERZIOVSKI, M.; POWER, D.; SOHAL, A.S. The longitudinal effects of the ISO 9000 certification process on business performance. European Journal of Operational Research, v. 146, n. 3, p. 580-595, 2003.

TERZIOVSKI, M.; SAMSON, D.; DOW, D. The business value of quality management systems certification. Evidence from Australia and New Zealand. Journal of Operations Management, v. 15, n. 1, p. 1-18, 1997.

THE BRITISH STANDARDS INSTITUTION. ISO 45001:2016. 2015. Acesso em: 3 jul. 2015. Disponível em: < http://www.bsigroup.com/en-ID/BS-OHSAS-18001/BSOHSAS-18001-revision/>.

THE CLUB OF ROME. About the CLUB OF ROME. 2014. Disponível em: < http://www.clubofrome.org/>. Acesso em 05 Nov. 2014.

TSAI, W.H.; CHOU, W.C. Selecting management systems for sustainable development in SMEs: A novel hybrid model based on DEMATEL, ANP, and ZOGP. Expert 
Systems with Applications, v. 36, n. 2, p. 1444-1458, 2009.

TURNER, G. M. A comparison of The Limits to Growth with 30 years of reality. Global Environmental Change-Human and Policy Dimensions, v. 18, n. 3, p. 397$411,2008$.

UNITED NATIONS. Kyoto Protocol. 2014. Disponível em: < http://unfccc.int/kyoto_protocol/items/2830.php>. Acesso em: 05 Nov. 2014.

VALLS, V.M. O enfoque por processos da NBR ISO 9001 e sua aplicação nos serviços de informação. Ciência da informação, v. 33, n. 2, p. 172-178. Disponível em: < http://www.scielo.br/scielo.php?pid=S0100-19652004000200018\&script=sci_arttext $>$. Acesso em: 21 Set. 2015.

VIOLA, E.; FRANCHINI, M. Os limites planetários, a Rio+20 e o papel do Brasil. Cadernos EBAPER.BR. , v. 10, nº 3, Rio de Janeiro, Set. 2012.

VITORELI, G. A.; CARPINETTI, L. C. R. Análise da integração dos sistemas de gestão normalizados ISO 9001 e OHSAS 18001: estudo de casos múltiplos. Gestão \& Produção, v. 20, n. 1, p. 204-217, 2013.

VITORELI, G.A. Análise da integração dos sistemas de gestão normalizados ISO 9001 e OHSAS 18001: estudo de casos múltiplos. 145 f. Dissertação (mestrados). Escola de Engenharia de São Carlos, Universidade de São Paulo, São Carlos. 2011.

WAGNER, M. How to reconcile environmental and economic performance to improve corporate sustainability: corporate environmental strategies in the European paper industry. Journal of Environmental Management, v. 76, n. 2, p. 105-118, 2005.

WAGNER, M. The role of corporate sustainability performance for economic performance: A firm-level analysis of moderation effects. Ecological Economics, v. 69, n. 7, p. 1553-1560, 2010.

ZENG, S. X.; TIAN, P.; TAM, C. M. Quality assurance in design organizations: a case study in China. Managerial Auditing Journal, v. 20, n. 7, p. 679-690, 2005. 


\section{APENDICES}


Apêndice 1. Requisitos da sustentabilidade empresarial identificados nesse trabalho.

\begin{tabular}{|c|c|c|c|c|}
\hline \multirow{2}{*}{ Dim. } & \multirow[b]{2}{*}{ Requisitos da sustentabilidade empresarial } & \multicolumn{3}{|c|}{ Referências } \\
\hline & & GRI (2013) & Ethos (2013) & ISE (2013) \\
\hline \multirow{15}{*}{. } & $\begin{array}{l}\text { 1. Elaborar política para que os indicadores/dados/informações advindos do processo de } \\
\text { diálogo e engajamento das partes interessadas sejam, preservadas (quando confidencial), } \\
\text { comparáveis, confiáveis, relevantes e compreensíveis por suas partes interessadas. }\end{array}$ & & - & $\mathrm{X}$ \\
\hline & $\begin{array}{l}\text { 2. Valorizar a diversidade, equidade e não discriminação ( racial, gênero, opção sexual ou } \\
\text { qualquer outra forma de discriminação). }\end{array}$ & $\mathrm{X}$ & $\mathrm{X}$ & $\mathrm{X}$ \\
\hline & 3.Considerar a responsabilidade social na cadeia de fornecimento. & & $\mathrm{X}$ & $\mathrm{X}$ \\
\hline & 4. Engajar as partes interessadas. & & $\mathrm{X}$ & $\mathrm{X}$ \\
\hline & $\begin{array}{l}\text { 5. Participar do processo de elaboração, avaliação, implantação ou monitoramento de políticas } \\
\text { públicas. }\end{array}$ & $\mathrm{X}$ & $\mathrm{X}$ & $\mathrm{X}$ \\
\hline & 6. Apoiar, patrocinar e desenvolver projetos, programas, campanhas e pesquisas científicas. & $\mathrm{X}$ & $\mathrm{X}$ & $\mathrm{X}$ \\
\hline & 7. Oferecer oportunidade de trabalho para grupos vulneráveis. & & $\mathrm{X}$ & \\
\hline & 8. Estimular os funcionários a cumprirem os valores e princípios éticos da organização. & & $\mathrm{X}$ & \\
\hline & 9. Garantir o atendimento dos direitos humanos. & $\mathrm{X}$ & & \\
\hline & $\begin{array}{l}\text { 10.Elaborar programas de aconselhamento sobre o planejamento de carreiras, de forma a } \\
\text { auxiliar os empregados na reflexão sobre suas funções e identificação de objetivos em longo } \\
\text { prazo. }\end{array}$ & & $\mathrm{X}$ & \\
\hline & $\begin{array}{l}\text { 11.Elaborar programa sistemático de preparação interna, oferecendo oportunidades de } \\
\text { aproveitamento da capacidade de trabalho dos aposentados. }\end{array}$ & & $\mathrm{X}$ & \\
\hline & $\begin{array}{l}\text { 12.Elaborar programa para empregar, na medida do possível, o maior número de moradores do } \\
\text { local em que está inserida, dando-lhes formação, com o objetivo de aumentar os níveis de } \\
\text { qualificação daquela comunidade, em cooperação com sindicatos, ONGs, representantes da } \\
\text { comunidade ou autoridades públicas competente. }\end{array}$ & & $\mathrm{X}$ & $\mathrm{X}$ \\
\hline & 13. Elaborar programa específico de contratação de pessoas com deficiência. & & $\mathrm{X}$ & \\
\hline & $\begin{array}{l}\text { 14. Identificar os tipos e taxas de lesões, doenças ocupacionais, dias perdidos, absenteísmo e } \\
\text { número de óbitos relacionados ao trabalho, discriminados por região e gênero. }\end{array}$ & $\mathrm{X}$ & & \\
\hline & $\begin{array}{l}\text { 15. Estabelecer acordos formais entre as empresas, sindicatos e colaboradores para manter o } \\
\text { direito dos colaboradores. }\end{array}$ & $\mathrm{X}$ & & \\
\hline \multirow{13}{*}{ 吾 } & 16. Garantir a preservação das Áreas de Preservação Permanente (APP). & & & $\mathrm{X}$ \\
\hline & 17. Delimitar a área de Reserva Legal em situações aplicáveis. & & & $\mathrm{X}$ \\
\hline & 18. Possuir todas as licenças necessárias no licenciamento ambiental. & & & $\mathrm{X}$ \\
\hline & 19. Considerar a questão das mudanças climáticas. & & & $\mathrm{X}$ \\
\hline & $\begin{array}{l}\text { 20. Elaborar Política Ambiental (deve ser formal, de conhecimento de todos os empregados e } \\
\text { constar no código de conduta e/ou na declaração de valores das empresas). }\end{array}$ & & $\mathrm{X}$ & $\mathrm{X}$ \\
\hline & 21. Contribuir para a preservação da biodiversidade por meio de políticas específicas. & & $\mathrm{X}$ & $\mathrm{X}$ \\
\hline & 22. Possuir área ou comitê responsável pelo meio ambiente. & & $\mathrm{X}$ & \\
\hline & 23. Exigir estudos de impacto ambiental em toda a cadeia produtiva. & & $\mathrm{X}$ & \\
\hline & $\begin{array}{l}\text { 24. Possuir planos de emergência ambiental, que relacionem todos os seus processos e } \\
\text { produtos ou serviços que envolvam situações de risco, e treinar seus empregados regularmente } \\
\text { para enfrentar tais situações. }\end{array}$ & & $\mathrm{X}$ & \\
\hline & 25.Identificar e monitorar os riscos e os aspectos ambientais. & & $\mathrm{X}$ & \\
\hline & 26. Elaborar planos de ações. & & $\mathrm{X}$ & \\
\hline & 27. Divulgar o inventário de emissões de GEE. & & & $\mathrm{X}$ \\
\hline & $\begin{array}{l}\text { 28. Os processos de gestão da companhia devem incorporar o uso sustentável dos recursos } \\
\text { naturais renováveis como requisito prioritário. }\end{array}$ & & & $\mathrm{X}$ \\
\hline \multirow{12}{*}{ 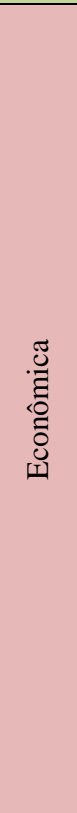 } & $\begin{array}{l}\text { 29. Adotar políticas para os ativos intangíveis (capital organizacional, capital humano, capital } \\
\text { de informação e capital reputacional). }\end{array}$ & & & $\mathrm{X}$ \\
\hline & 30. Considerar os valores da defesa da concorrência em suas políticas corporativas. & & & $\mathrm{X}$ \\
\hline & $\begin{array}{l}\text { 31. Elaborar processos e procedimentos implementados de gestão de riscos corporativos (risco } \\
\text { estratégico, risco operacional, risco financeiro - mercado, crédito e liquidez, risco reputacional } \\
\text { e risco legal) que considerem aspectos de curto, médio e longo prazo, acompanhados pelo } \\
\text { Conselho de Administração. }\end{array}$ & & & $\mathrm{X}$ \\
\hline & 32. Restringir o uso de instrumentos financeiros derivativos para fins exclusivos de proteção. & & & $\mathrm{X}$ \\
\hline & $\begin{array}{l}\text { 33. Implementar processos e procedimentos para monitorar impactos econômicos indiretos das } \\
\text { atividades da companhia. }\end{array}$ & & & $\mathrm{X}$ \\
\hline & $\begin{array}{l}\text { 34. Elaborar processos e procedimentos implementados de gestão de ativos intangíveis, além } \\
\text { dos contabilizados. }\end{array}$ & & & $\mathrm{X}$ \\
\hline & $\begin{array}{l}\text { 35. Possuir sistema de gestão de desempenho baseado em indicadores vinculados ao } \\
\text { planejamento estratégico. }\end{array}$ & & & $\mathrm{X}$ \\
\hline & 36. Implantar medidas de defesa da concorrência. & & & $\mathrm{X}$ \\
\hline & 37. Preparar e publicar as demonstrações financeiras em moeda constante. & & & $\mathrm{X}$ \\
\hline & 38. Calcular o lucro econômico ou outras medidas de geração de valor econômico. & & & $\mathrm{X}$ \\
\hline & $\begin{array}{l}\text { 39. Relatar o valor econômico direto (receitas) gerado e distribuído (custos operacionais; } \\
\text { salários e benefícios de empregados; pagamentos a provedores de capital; pagamentos ao } \\
\text { governo (por país); investimentos comunitários), com base no regime de competência de } \\
\text { exercícios. }\end{array}$ & $\mathrm{X}$ & & \\
\hline & 40. Elaborar um plano de benefícios da organização. & $\mathrm{X}$ & & \\
\hline
\end{tabular}


Apêndice 1. Continuação...

Requisitos da sustentabilidade

41. Comprometimento da alta direção com as questões socioambientais.

42. Incorporar critérios socioambiental na estratégia da organização.

43. Comunicar a toda a organização e outras partes interessadas a importância de considerar os aspectos socioambientais.

44. A responsabilidade socioambiental deve ser repassada em toda a cadeia produtiva.

45. Possuir normas de seleção e avaliação de fornecedores que contemplam critérios específicos de responsabilidade socioambiental.

46. Produzir relatórios periódicos com evidências de que questões relacionadas à responsabilidade socioambiental empresarial estão sendo cumpridas e implementadas em sua cadeia produtiva.

47. Caso necessário treinar os fornecedores para que se adequem as questões relacionadas a responsabilidade socioambiental.

48. Participar de comitês/conselhos locais ou regionais para discutirem a questão ambiental com o governo e a comunidade.

49. Desenvolver campanhas, apoiar ou participar de projetos educacionais em parceria com organizações não governamentais e ambientalistas, exercendo liderança social em favor dessa causa.

50. Disponibilizar suporte técnico aos consumidores finais com vistas ao uso sustentável de seus produtos ou serviços.

51. Fornecer aos consumidores e clientes informações detalhadas sobre danos socioambientais resultantes do uso e na destinação final de seus produtos.

52. Divulgar informações a respeito dos aspectos e impactos ambientais gerados pela organização.

53. Mecanismos de Queixas e Reclamações Relativas a Impactos Ambientais.

54. Elaborar políticas que garanta a saúde e segurança dos colaboradores e outras partes interessadas.

55. Elaborar políticas trabalhistas, remuneração, benefícios e carreira.

56. Elaborar política(s) que aborde $(\mathrm{m})$ as questões relacionadas aos clientes.

57. Oferecer condições de trabalho ideal para os colaboradores, terceirizados e outras partes interessadas (treinamentos, infraestrutura, incentivos, desenvolvimento profissional, entre outros).

58. Manter um canal de diálogo com os clientes, funcionários, fornecedores e distribuidores.

59. Incluir entre seus fornecedores indivíduos ou grupos da comunidade, tais como cooperativas de pequenos produtores ou de iniciativas solidárias, associações de bairro e organizações com projetos de geração de renda para grupos usualmente excluídos (populações indígenas, pessoas com deficiência etc.).

60. Elaborar programa de mapeamento para identificação de competências potenciais a serem desenvolvidas.

61. Identificar empregados com alta incidência ou alto risco de doenças relacionadas à sua ocupação.

62. Adotar política contínua de esclarecimento aos funcionários sobre defesa da concorrência. 63. Manter os valores dos salários dos colaboradores sem distinção de gênero.

64. Desenvolver programas internos de melhoramento ambiental.

65. Possuir programas de gerenciamento de resíduos.

66. Possuir programas específicos para verificar a origem e a cadeia de produção dos insumos madeireiros e florestais utilizados em sua operação diária e/ou processo produtivo.

67. Priorizar políticas preventivas.

68. Possuir políticas e sistema de monitoramento visando o aumento da qualidade ambiental 69. Participar da destinação final dos produtos e processos pós-consumo.

70. Sem alterar seus padrões tecnológicos atuais, procurar reduzir o consumo de energia, de água, de produtos tóxicos e de matérias-primas e implantar processos para a destinação adequada de resíduos.

71. Considerar os passivos ambientais.

72. Possuir seguro para degradação ambiental decorrente de acidentes em suas operações.

73. Considera a abordagem baseado no ciclo de vida dos produtos.

74. Possuir processo para medir, monitorar e auditar periodicamente os aspectos ambientais significativos relacionados ao consumo de recursos naturais e à produção de resíduos e dejetos, estabelecendo periodicamente novas metas.

75. Monitorar o consumo de recursos naturais na cadeia produtiva.

76. Considerar iniciativas tais como "ecodesign" ou DfE (Desing for Environment).

77. As estratégias envolvendo a definição de produtos e/ou serviços oferecidos pela companhia e/ou por suas controladas ou os projetos de Pesquisa e Desenvolvimento elaborados pelas mesmas preveem planos para reposicionamento (refere-se à mudança no mix de produtos/serviços do portfólio e/ou público-alvo) em função das potenciais mudanças nos padrões de oferta e demanda de recursos naturais.

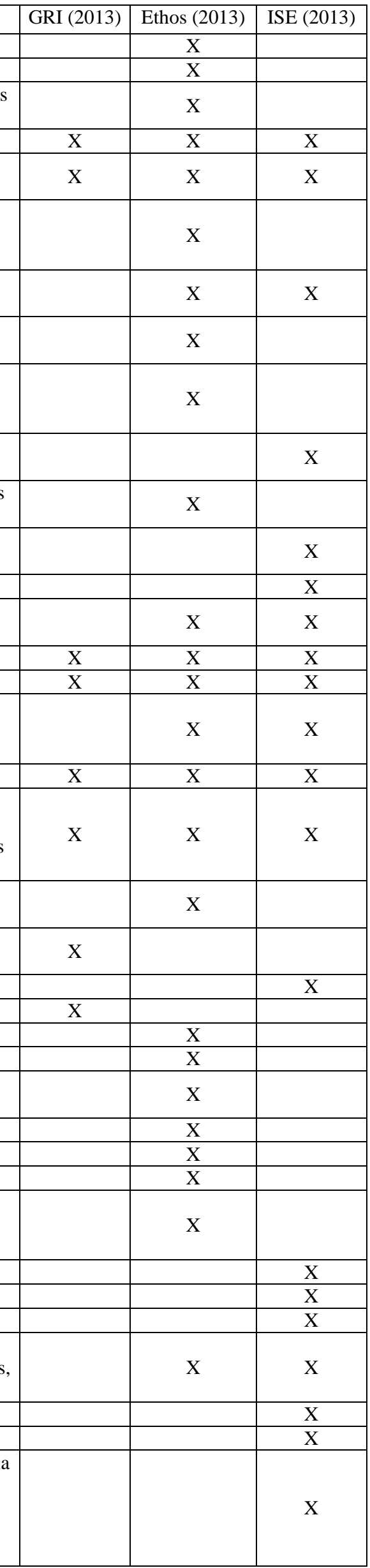


Apêndice 1. Continuação...

\begin{tabular}{|c|c|c|c|c|}
\hline Dim. & Requisitos da sustentabilidade empresarial & GRI (2013) & Ethos (2013) & ISE (2013) \\
\hline \multirow{4}{*}{ 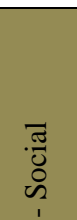 } & 78. Elaborar política de comunicacão. & & $\mathrm{X}$ & \\
\hline & 79. Assumir uma postura ética. & & $\mathrm{X}$ & \\
\hline & $\begin{array}{l}\text { 80. Identificar as partes interessadas e conhecer o contexto em que cada parte está inserida } \\
\text { para que as mesmas possam auxiliar na mitigação dos impactos socioambientais envolvidos } \\
\text { em cada contexto. }\end{array}$ & & $\mathrm{X}$ & $\mathrm{X}$ \\
\hline & 81. Manter o diálogo com as partes interessadas. & $\mathrm{X}$ & $\mathrm{X}$ & $\mathrm{X}$ \\
\hline \multirow{3}{*}{$\begin{array}{l}\text { 苞 } \\
\frac{0}{0} \\
\text { ह }\end{array}$} & 82. Monitorar os impactos causados por suas atividades na comunidade de entorno. & & $\mathrm{X}$ & \\
\hline & $\begin{array}{l}\text { 83. Possuir conselho ou responsável formal por questões éticas internas e externas e garantir a } \\
\text { gerência eficaz. }\end{array}$ & & $\mathrm{X}$ & $\mathrm{X}$ \\
\hline & 84. Não praticar concorrência desleal. & $\mathrm{X}$ & $\mathrm{X}$ & \\
\hline \multirow{5}{*}{ 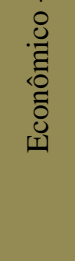 } & 85. Cumprir a legislação e pagamentos de tributos. & $\mathrm{X}$ & $\mathrm{X}$ & \\
\hline & 86. Comunicar o compromisso com o desenvolvimento sustentável. & & & $\mathrm{X}$ \\
\hline & 87. Definir responsabilidades e autoridades. & & & $\mathrm{X}$ \\
\hline & $\begin{array}{l}\text { 88. Existir processos e procedimentos implementados para gestão de oportunidades } \\
\text { corporativas que considere aspectos socioambientais de curto, médio e longo prazo. }\end{array}$ & & & $\mathrm{X}$ \\
\hline & $\begin{array}{l}\text { 89. Possuir plano de contigência que considere desastres naturais, impactos ambientais, } \\
\text { impactos sociais, impactos em infraestrutura/operacionais (incluindo TI). }\end{array}$ & & & $X$ \\
\hline
\end{tabular}


Apêndice 2. Termo de abertura da pesquisa

\section{TERMO DE ABERTURA DA PESQUISA}

\section{Justificativa da Pesquisa}

A sustentabilidade é um tema que está sendo inserido no contexto empresarial como uma forma de minimizar os impactos causados pelos processos produtivos. Diante desse contexto, as organizações utilizam ferramentas como normas de sistema de gestão ISO 14001, ISO 9001, OHSAS 18001 e NBR 16001 para auxiliar a satisfazer os anseios das partes interessadas. Tem-se observado que as certificações estão sendo cada vez mais obtidas com o passar do tempo. No cenário científico identifica-se autores que apontam que essas normas auxiliam as empresas a melhorarem seu desempenho ambiental, social e econômico contemplando as dimensões da sustentabilidade e outros de discordam dessas afirmações. Diante dessas discussões o estudo de caso auxiliará a responder a seguinte pergunta:

Qual a relação entre as normas de sistema de gestão e sustentabilidade corporativa?

\section{Premissas da Pesquisa}

As premissas para a realização da pesquisa são:

- Permissão para acessar documentos necessários ao decorrer da pesquisa como uma forma de garantir a qualidade da mesma;

- Comprometimento dos gestores que serão entrevistados em responder as perguntar realizadas com fidelidade;

- Os pesquisadores assumem o compromisso ético de não divulgar o nome, informações confidencias, documentos, entre outros requisitos que a empresa julgue importante no final da pesquisa.

- Não haverá custos para a empresa participante do estudo de caso, salvo o tempo de seus profissionais para a participação em reuniões, realização de entrevistas, preenchimento de questionários, etc.

- Os pesquisadores assumem o compromisso de enviar um relatório para a empresa participante do estudo de caso com os resultados desta pesquisa.

\section{Implicações Éticas}

Não divulgar informações confidenciais da empresa. 


\section{ASSINATURA DO TERMO DE ABERTURA DA PESQUISA}

Responsabilidade dos Pesquisadores,

Nós, Camila dos Santos Ferreira e Prof. Dr. Mateus Gerolamo Cecílio, pesquisadores do Programa de Pós-Graduação em Engenharia de Produção EESC/USP declaramos a responsabilidade de desenvolver a pesquisa de acordo com os termos descritos anteriormente e acordados entre as partes. Além disso, nos comprometemos a não divulgar informações confidencias e nem o nome da organização em nenhum meio de divulgação, sejam nos meios acadêmicos ou outras mídias.

Mestranda Camila dos Santos Ferreira

E-mail: ferreira.camila@usp.br

Prof. Dr. Mateus Cecílio Gerolamo E-mail: gerolamo@sc.usp.br

Autorização e Responsabilidade do Cliente,

$\mathrm{Eu},($ ), autorizo a realização deste projeto, bem como, prover dos recursos necessários, em acordo com os termos anteriormente descritos e acordados entre as partes. 
Apêndice 3. Matriz de Relação Consolidada ISO 9001 - Dimensão Social.

\begin{tabular}{|c|c|c|c|c|c|c|c|c|c|c|c|c|c|c|c|c|c|c|c|c|c|c|c|}
\hline \multirow[b]{2}{*}{$\begin{array}{l}\text { Requisitos da sustentabilidade } \\
\text { empresarial - Dimensão social }\end{array}$} & \multicolumn{2}{|c|}{4.} & \multicolumn{6}{|c|}{5} & \multicolumn{3}{|c|}{6.} & \multicolumn{6}{|c|}{7.} & \multicolumn{5}{|c|}{8.} & \multirow[b]{2}{*}{ 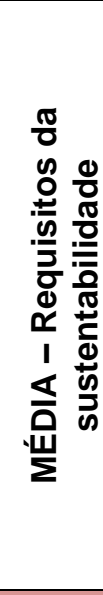 } \\
\hline & 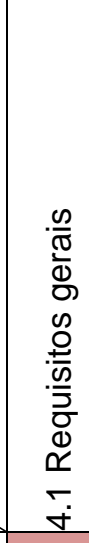 & 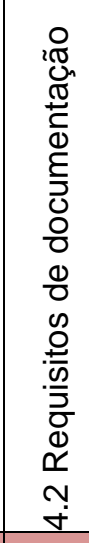 & 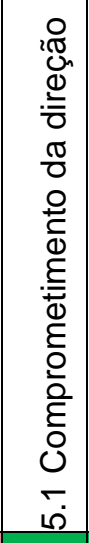 & 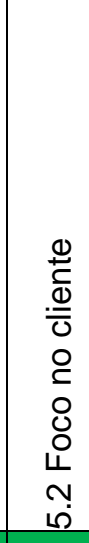 & 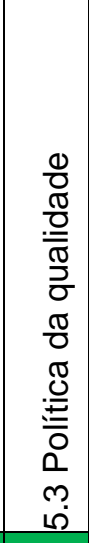 & 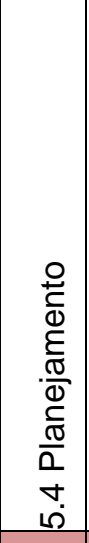 & 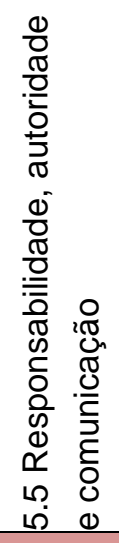 & 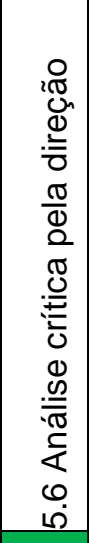 & $\begin{array}{l}0 \\
0 \\
00 \\
\overline{0} \\
0 \\
0 \\
0 \\
0 \\
0 \\
0 \\
0 \\
0 \\
0 \\
0 \\
0 \\
0 \\
0\end{array}$ & 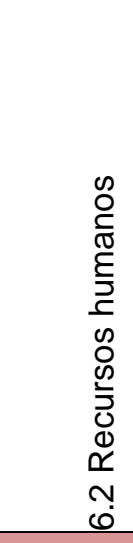 & 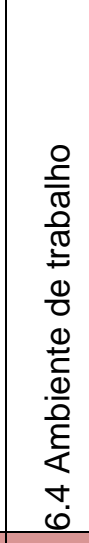 & 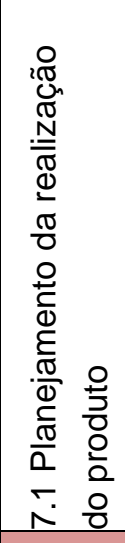 & 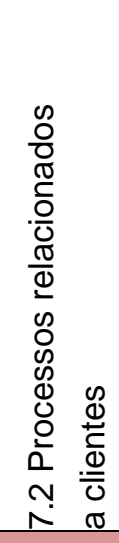 & 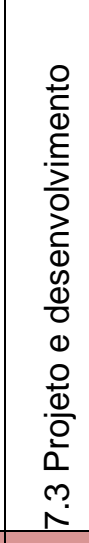 & 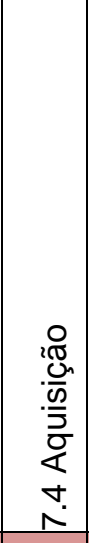 & 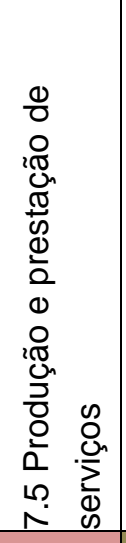 & 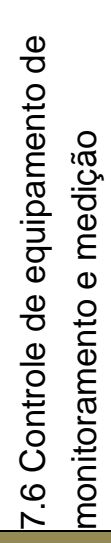 & $\begin{array}{l}0 \\
\mathbb{0} \\
0 \\
\frac{\pi}{0} \\
\frac{0}{\pi} \\
\frac{\pi}{0} \\
\stackrel{0}{0} \\
0 \\
0 \\
- \\
\infty\end{array}$ & 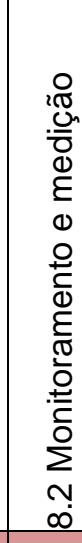 & 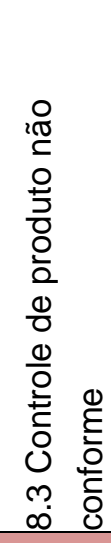 & 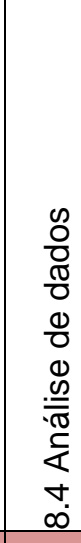 & 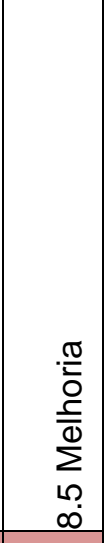 & \\
\hline $\begin{array}{l}\text { 1. Elaborar política para que os indicadores/dados/informações } \\
\text { advindos do processo de diálogo e engajamento das partes } \\
\text { interessadas sejam, preservadas (quando confidencial), } \\
\text { comparáveis, confiáveis, relevantes e compreensíveis por suas } \\
\text { partes interessadas (Ethos, 2013) e (ISE, 2013). }\end{array}$ & 2,25 & 2,25 & 4,5 & 4,5 & 6 & 2,25 & 2,25 & 4,5 & 3 & 3 & 2,25 & 3 & 3 & 3 & 2,25 & 3 & 1,5 & 2,25 & 2,25 & 2,25 & 2,25 & 2,25 & 2,89 \\
\hline $\begin{array}{l}\text { 2. Valorizar a diversidade, equidade e não discriminação ( racial, } \\
\text { gênero, opção sexual ou qualquer outra forma de discriminação) } \\
\text { (Ethos, 2013), (ISE, 2013) e (GRI). }\end{array}$ & 0,75 & 0,75 & 1,5 & 0,75 & 0,75 & 0,75 & 0,75 & 0,75 & 0,75 & 4,5 & 3,75 & 0,75 & 0,75 & 0,75 & 0,75 & 0,75 & 0,75 & 0,75 & 0,75 & 0,75 & 0,75 & 0,75 & 1,09 \\
\hline $\begin{array}{l}\text { 3.Considerar a responsabilidade social na cadeia de fornecimento } \\
\text { (Ethos, 2013) e (ISE, 2013). }\end{array}$ & 0,75 & 0,75 & 0,75 & 0,75 & 0,75 & 0,75 & 0,75 & 0,75 & 0,75 & 0,75 & 0,75 & 0,75 & 0,75 & 0,75 & 1,5 & 0,75 & 0,75 & 0,75 & 0,75 & 0,75 & 0,75 & 0,75 & 0,78 \\
\hline 4. Engajar as partes interessadas (Ethos, 2013) e (ISE, 2013). & 0,75 & 0,75 & 3 & 1,5 & 0,75 & 0,75 & 2,25 & 2,25 & 1,5 & 5,25 & 3 & 0,75 & 0,75 & 0,75 & 0,75 & 0,75 & 0,75 & 2,25 & 0,75 & 0,75 & 0,75 & 0,75 & 1,43 \\
\hline $\begin{array}{l}\text { 5. Participar do processo de elaboração, avaliação, implantação ou } \\
\text { monitoramento de políticas públicas (Ethos, 2013), (ISE, 2013) e } \\
\text { (GRI). }\end{array}$ & 0 & 0 & 0 & 0 & 0 & 0 & 0 & 0 & 0 & 0 & 0 & 0 & 0 & 0 & 0 & 0 & 0 & 0 & 0 & 0 & 0 & 0 & 0 \\
\hline $\begin{array}{l}\text { 6. Apoiar, patrocinar e desenvolver projetos, programas, } \\
\text { campanhas e pesquisas científicas (Ethos, 2013), (ISE, 2013) e } \\
\text { (GRI). }\end{array}$ & 0,75 & 0,75 & 0,75 & 0,75 & 2,25 & 3 & 0,75 & 0,75 & 3 & 0,75 & 0,75 & 4,5 & 0,75 & 3,75 & 0,75 & 0,75 & 0,75 & 0,75 & 0,75 & 0,75 & 0,75 & 4,5 & 1,5 \\
\hline $\begin{array}{l}\text { 7. Oferecer oportunidade de trabalho para grupos vulneráveis } \\
\text { (Ethos, 2013). }\end{array}$ & 0 & 0 & 0 & 0 & 0 & 0 & 0 & 0 & 0 & 0 & 0 & 0 & 0 & 0 & 0 & 0 & 0 & 0 & 0 & 0 & 0 & 0 & 0 \\
\hline $\begin{array}{l}\text { 8. Estimular os funcionários a cumprirem os valores e princípios } \\
\text { éticos da organização (Ethos, 2013). }\end{array}$ & 2,25 & 0,75 & 3 & 0,75 & 0,75 & 3 & 0,75 & 0,75 & 0,75 & 3,75 & 1,5 & 3 & 0,75 & 0,75 & 0,75 & 0,75 & 0,75 & 0,75 & 0,75 & 0,75 & 0,75 & 0,75 & 1,29 \\
\hline 9. Garantir o atendimento dos direitos humanos (GRI). & 2,25 & 0 & 0,75 & 0 & 0 & 0 & 3 & 0 & 0 & 2,25 & 4,5 & 0 & 0 & 0 & 0 & 0 & 0 & 0 & 0 & 0 & 0 & 0 & 0,58 \\
\hline $\begin{array}{l}\text { 10.Elaborar programas de aconselhamento sobre o planejamento } \\
\text { de carreiras, de forma a auxiliar os empregados na reflexão sobre } \\
\text { suas funçôes e identificação de objetivos em longo prazo (Ethos, } \\
\text { 2013). }\end{array}$ & 0,75 & 0 & 0,75 & 0 & 2,25 & 0 & 2,25 & 0 & 0 & 3,75 & 0 & 0 & 0 & 0 & 0 & 0 & 0 & 0 & 0 & 0 & 0 & 0 & 0,44 \\
\hline $\begin{array}{l}\text { 11.Elaborar programa sistemático de preparação interna, } \\
\text { oferecendo oportunidades de aproveitamento da capacidade de } \\
\text { trabalho dos aposentados (Ethos, 2013). }\end{array}$ & 0 & 0 & 1,5 & 0 & 1,5 & 0 & 0 & 0 & 0 & 5,25 & 0 & 0 & 0 & 0 & 0 & 0 & 0 & 0 & 0 & 0 & 0 & 0 & 0,37 \\
\hline $\begin{array}{l}\text { 12.Elaborar programa para empregar, na medida do possível, o } \\
\text { maior número de moradores do local em que está inserida, dando- } \\
\text { Ihes formação, com o objetivo de aumentar os níveis de } \\
\text { qualificação daquela comunidade, em cooperação com sindicatos, } \\
\text { ONGs, representantes da comunidade ou autoridades públicas } \\
\text { competentes (Ethos, 2013) e (ISE, 2013). }\end{array}$ & 0 & 0 & 0 & 0 & 0 & 0 & 0 & 0 & 0 & 0 & 0 & 0 & 0 & 0 & 0 & 0 & 0 & 0 & 0 & 0 & 0 & 0 & 0 \\
\hline $\begin{array}{l}\text { 13. Elaborar programa específico de contratação de pessoas com } \\
\text { deficiência (Ethos, 2013). }\end{array}$ & 0 & 0 & 0,75 & 0 & 0 & 0 & 0 & 0 & 0 & 2 & 0 & 0 & 0 & 0 & 0 & 0 & 0 & 0 & 0 & 0 & 0 & 0 & 0,12 \\
\hline $\begin{array}{l}\text { 14. Identificar os tipos e taxas de lesões, doenças ocupacionais, } \\
\text { dias perdidos, absenteísmo e número de óbitos relacionados ao } \\
\text { trabalho, discriminados por região e gênero (GRI). }\end{array}$ & 0 & 0 & 0,75 & 0 & 0 & 0 & 0,75 & 0,75 & 0 & 4,5 & 3,75 & 0 & 0 & 0 & 0 & 0 & 0 & 0 & 0 & 0 & 0 & 1,5 & 0,54 \\
\hline $\begin{array}{l}\text { 15. Estabelecer acordos formais entre as empresas, sindicatos e } \\
\text { colaboradores para manter o direito dos colaboradores (GRI). }\end{array}$ & 0 & 0 & 2,25 & 0 & 0 & 0 & 0,75 & 0,75 & 0 & 0,75 & 0,75 & 0 & 0 & 0 & 0 & 0 & 0 & 0 & 0 & 0 & 0 & 0,75 & 0,27 \\
\hline MÉDIA - Requisitos da ISO 9001 & 0,7 & 0,4 & 1,35 & 0,6 & 1 & 0,7 & 0,95 & 0,75 & 0,65 & 2,43 & 1,4 & 0,85 & 0,45 & 0,65 & 0,45 & 0,45 & 0,35 & 0,5 & 0,4 & 0,4 & 0,4 & 0,8 & 0,76 \\
\hline
\end{tabular}


Apêndice 4. Matriz de Relação Consolidada ISO 9001 - Dimensão Ambiental.

\begin{tabular}{|c|c|c|c|c|c|c|c|c|c|c|c|c|c|c|c|c|c|c|c|c|c|c|c|}
\hline \multirow[b]{2}{*}{$\begin{array}{l}\text { Requisitos da sustentabilidade } \\
\text { empresarial - Dimensão ambiental }\end{array}$} & \multicolumn{2}{|c|}{4.} & \multicolumn{6}{|c|}{5} & \multicolumn{3}{|c|}{6.} & \multicolumn{6}{|c|}{7.} & \multicolumn{5}{|c|}{8.} & \multirow{2}{*}{ 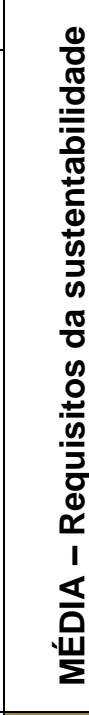 } \\
\hline & 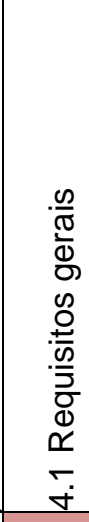 & 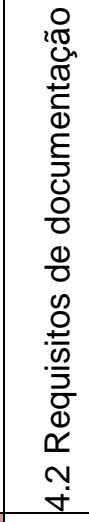 & 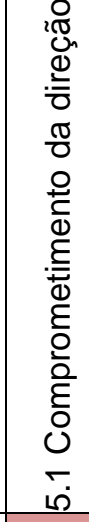 & 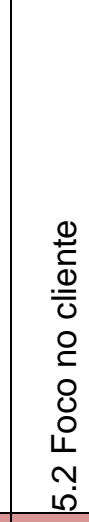 & 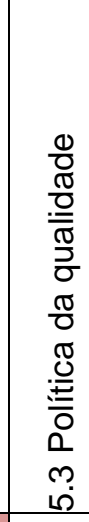 & 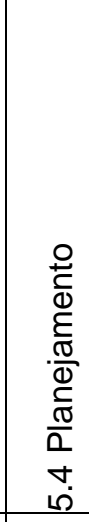 & 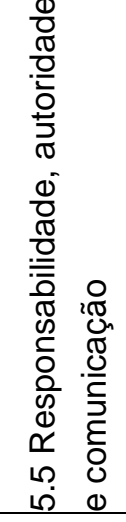 & 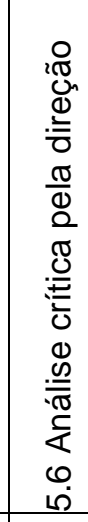 & $\begin{array}{l}\infty \\
0 \\
0 \\
\overline{0} \\
0 \\
\Phi \\
\Phi \\
0 \\
0 \\
0 \\
.0 \\
0 \\
0 \\
0 \\
0 \\
0\end{array}$ & 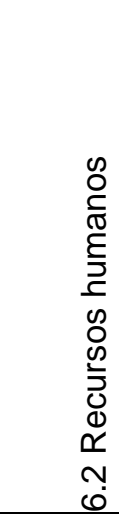 & 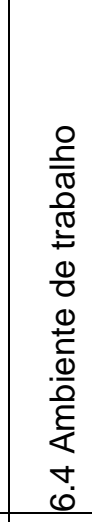 & 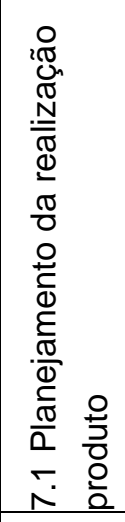 & 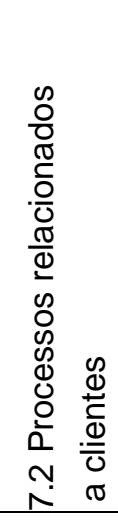 & $\begin{array}{l}0 \\
0 \\
0 \\
0 \\
\frac{E}{2} \\
0 \\
0 \\
0 \\
0 \\
0 \\
0 \\
0 \\
0 \\
0 \\
.0 \\
.0 \\
0 \\
0 \\
0 \\
0 \\
\end{array}$ & 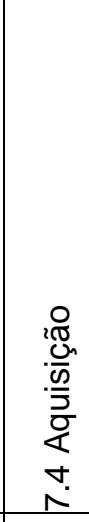 & 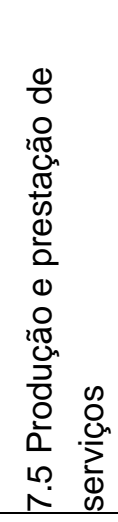 & 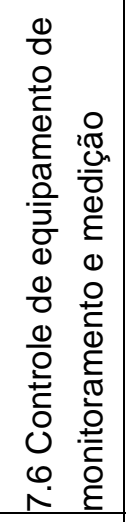 & 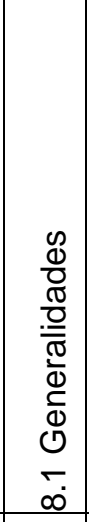 & 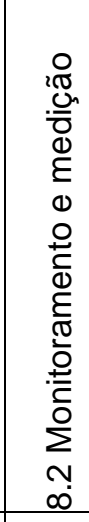 & $\begin{array}{l}0 \\
0 \\
0 \\
20 \\
20 \\
0 \\
0 \\
5 \\
0 \\
0 \\
0 \\
0 \\
0 \\
0 \\
0 \\
0 \\
0 \\
0 \\
0 \\
0 \\
0 \\
0 \\
\infty \\
0\end{array}$ & $\begin{array}{l}0 \\
0 \\
0 \\
\frac{0}{0} \\
0 \\
0 \\
0 \\
0 \\
\frac{0}{0} \\
\frac{0}{\pi} \\
\frac{\pi}{4} \\
0 \\
0 \\
\infty\end{array}$ & 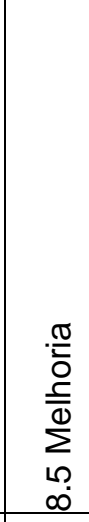 & \\
\hline $\begin{array}{l}\text { 16. Garantir a preservação das Áreas de Preservação } \\
\text { Permanente (APP) (ISE, 2013). }\end{array}$ & 2,25 & 0 & 2,25 & 2,25 & 0 & 0 & 0 & 0 & 0 & 0 & 0 & 0 & 0 & 0 & 0 & 0 & 0 & 0 & 0 & 0 & 0 & 0 & 0,31 \\
\hline $\begin{array}{l}\text { 17. Delimitar a área de Reserva Legal em situações aplicáveis } \\
\text { (ISE, 2013). }\end{array}$ & 2,25 & 0 & 0 & 0 & 0 & 0 & 0 & 0 & 0 & 0 & 0 & 0 & 0 & 0 & 0 & 0 & 0 & 0 & 0 & 0 & 0 & 0 & 0,11 \\
\hline $\begin{array}{l}\text { 18. Possuir todas as licenças necessárias no licenciamento } \\
\text { ambiental (ISE, 2013). }\end{array}$ & 2,25 & 0 & 0 & 2,25 & 0 & 0 & 0 & 0 & 0 & 0 & 0 & 0 & 0 & 0 & 0 & 0 & 0 & 0 & 0 & 0 & 0 & 0 & 0,21 \\
\hline 19. Considerar a questão das mudanças climáticas (ISE, 2013). & 0 & 0 & 0 & 0 & 0 & 0 & 0 & 0 & 0 & 0 & 0 & 0 & 0 & 0 & 0 & 0 & 0 & 0 & 0 & 0 & 0 & 0 & 0 \\
\hline $\begin{array}{l}\text { 20. Elaborar Política Ambiental (deve ser formal, de } \\
\text { conhecimento de todos os empregados e constar no código de } \\
\text { conduta e/ou na declaração de valores das empresas) (Ethos, } \\
\text { 2013) e (ISE, 2013). }\end{array}$ & 0 & 0 & 0 & 2,25 & 0 & 0 & 0 & 0 & 0 & 0 & 0 & 0 & 0 & 0 & 0 & 0 & 0 & 0 & 0 & 0 & 0 & 0 & 0,10 \\
\hline $\begin{array}{l}\text { 21. Contribuir para a preservação da biodiversidade por meio } \\
\text { de políticas específicas (Ethos, 2013) e (ISE, 2013). }\end{array}$ & 0 & 0 & 0 & 2,25 & 0 & 0 & 0 & 0 & 0 & 0 & 0 & 0 & 0 & 0 & 0 & 0 & 0 & 0 & 0 & 0 & 0 & 0 & 0,10 \\
\hline $\begin{array}{l}\text { 22. Possuir área ou comitê responsável pelo meio ambiente } \\
\text { (Ethos, 2013). }\end{array}$ & 2,25 & 0 & 0 & 0 & 0 & 0 & 2,25 & 0 & 0 & 0 & 0 & 0 & 0 & 0 & 0 & 0 & 0 & 0 & 0 & 0 & 2,25 & 0 & 0,31 \\
\hline $\begin{array}{l}\text { 23. Exigir estudos de impacto ambiental em toda a cadeia } \\
\text { produtiva (Ethos, 2013). }\end{array}$ & 0 & 0 & 0 & 0 & 0 & 0 & 0 & 0 & 0 & 0 & 0 & 0 & 0 & 0 & 0 & 0 & 0 & 0 & 0 & 0 & 0 & 0 & 0 \\
\hline $\begin{array}{l}\text { 24. Possuir planos de emergência ambiental, que relacionem } \\
\text { todos os seus processos e produtos ou serviços que envolvam } \\
\text { situações de risco, e treinar seus empregados regularmente } \\
\text { para enfrentar tais situações (Ethos, 2013). }\end{array}$ & 0 & 0 & 0 & 2,25 & 0 & 0 & 0 & 0 & 0 & 0 & 0 & 0 & 0 & 0 & 0 & 0 & 0 & 0 & 0 & 0 & 0 & 0 & 0,10 \\
\hline $\begin{array}{l}\text { 25.Identificar e monitorar os riscos e os aspectos ambientais } \\
\text { (Ethos, 2013). }\end{array}$ & 0 & 0 & 0 & 2,25 & 0 & 0 & 0 & 0 & 0 & 0 & 0 & 0 & 0 & 0 & 0 & 0 & 0 & 0 & 0 & 0 & 0 & 0 & 0,10 \\
\hline 26. Elaborar planos de ações (Ethos, 2013). & 0 & 0 & 0 & 0 & 3 & 0 & 0 & 0 & 0 & 0 & 0 & 4,5 & 0 & 0 & 0 & 0 & 0 & 0 & 0 & 0 & 0 & 0 & 0,34 \\
\hline 27. Divulgar o inventário de emissões de GEE (ISE, 2013). & 0 & 0 & 0 & 0 & 2,25 & 0 & 0 & 0 & 0 & 0 & 0 & 0 & 0 & 0 & 0 & 0 & 0 & 0 & 0 & 0 & 0 & 0 & 0,10 \\
\hline $\begin{array}{l}\text { 28. Os processos de gestão da companhia devem incorporar o } \\
\text { uso sustentável dos recursos naturais renováveis como } \\
\text { requisito prioritário (ISE, 2013). }\end{array}$ & 0 & 0 & 0 & 2,25 & 2,25 & 0 & 0 & 0 & 0 & 0 & 0 & 0 & 0 & 0 & 0 & 0 & 0 & 0 & 0 & 0 & 0 & 0 & 0,21 \\
\hline MÉDIA - Requisitos da ISO 9001 & 0,69 & 0,00 & 0,17 & 1,21 & 0,58 & 0,00 & 0,17 & 0,00 & 0,00 & 0,00 & 0,00 & 0,35 & 0,00 & 0,00 & 0,00 & 0,00 & 0,00 & 0,00 & 0,00 & 0,00 & 0,17 & 0,00 & 0,15 \\
\hline
\end{tabular}


Apêndice 5. Matriz de Relação Consolidada ISO 9001 - Dimensão Econômica.

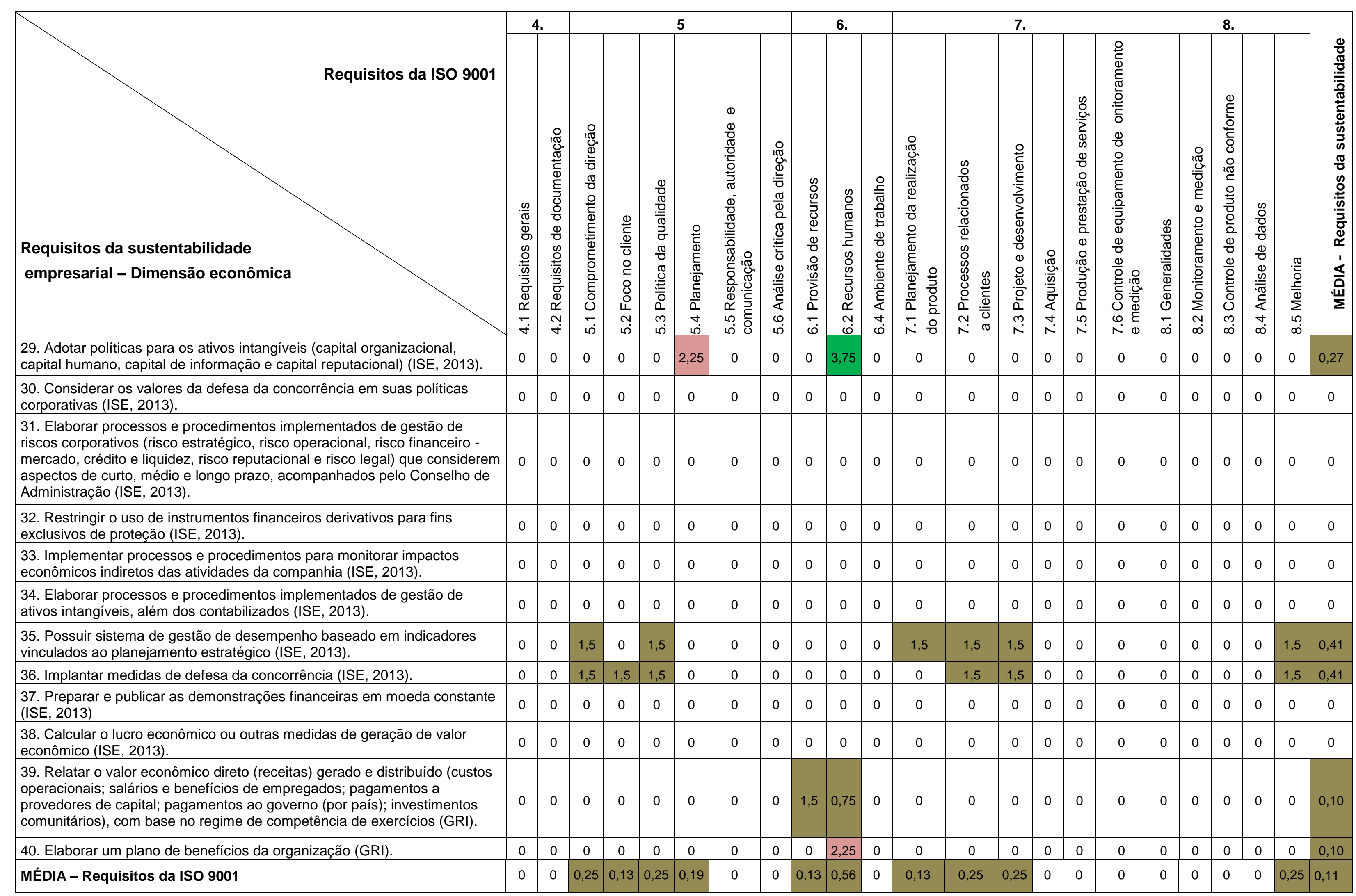


Apêndice 6. Matriz de Relação Consolidada ISO 9001 - Dimensão Socioambiental.

\begin{tabular}{|c|c|c|c|c|c|c|c|c|c|c|c|c|c|c|c|c|c|c|c|c|c|c|c|}
\hline \multirow[b]{2}{*}{$\begin{array}{l}\text { Requisitos da sustentabilidade } \\
\text { empresarial - Dimensão Socioambiental }\end{array}$} & \multicolumn{2}{|c|}{4.} & \multicolumn{6}{|c|}{5} & \multicolumn{3}{|c|}{6.} & \multicolumn{6}{|c|}{7.} & \multicolumn{5}{|c|}{8.} & \multirow[b]{2}{*}{ 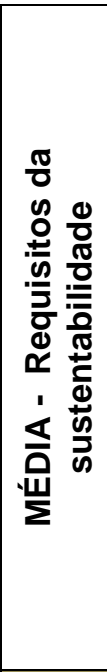 } \\
\hline & 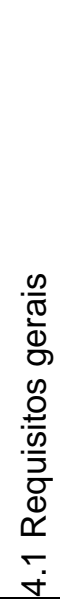 & 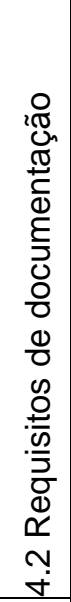 & 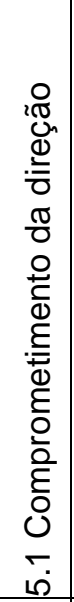 & 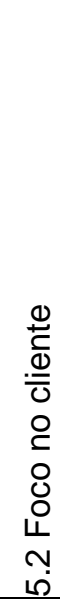 & 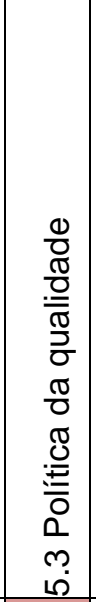 & 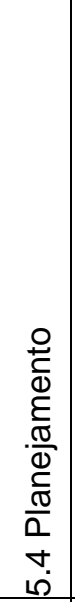 & 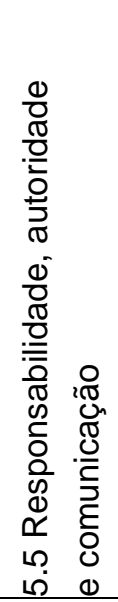 & 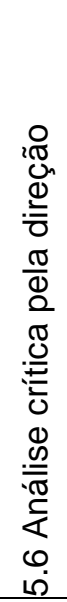 & 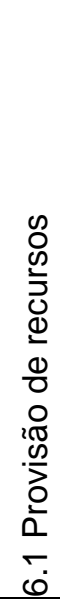 & 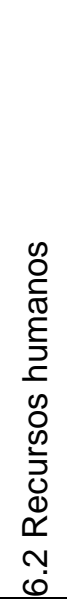 & 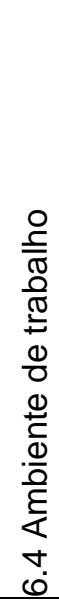 & 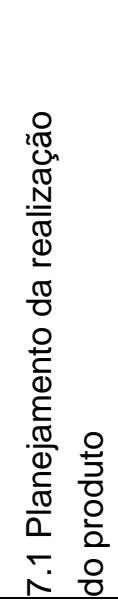 & 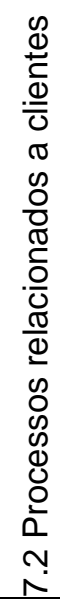 & 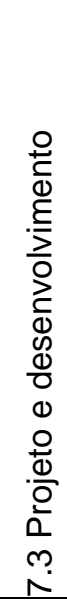 & 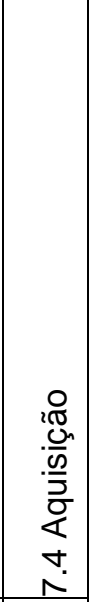 & $\begin{array}{c}0 \\
0 \\
.00 \\
20 \\
0 \\
0 \\
0 \\
0 \\
0 \\
0 \\
\mathbb{T} \\
00 \\
0 \\
0 \\
0 \\
0 \\
10 \\
0 \\
0 \\
0 \\
0 \\
10 \\
1\end{array}$ & 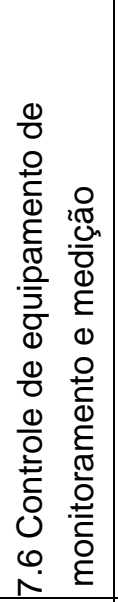 & 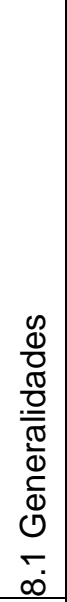 & 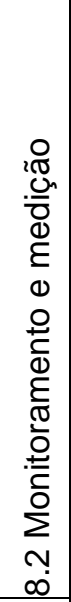 & 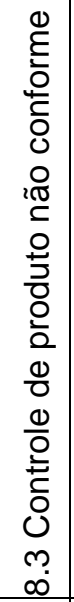 & 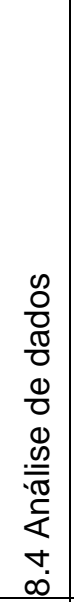 & $\begin{array}{l}\stackrel{\sigma}{0} \\
\overline{0} \\
\overline{0} \\
\sum_{20}^{0} \\
\infty \\
\infty\end{array}$ & \\
\hline $\begin{array}{l}\text { 41. Comprometimento da alta direção com as questões socioambientais } \\
\text { (Ethos, 2013). }\end{array}$ & 0 & 0 & 0 & 0 & 2,25 & 0 & 0 & 0 & 0 & 0 & 0 & 0 & 0 & 0 & 0 & 0 & 0 & 0 & 0 & 0 & 0 & 0 & 0,1 \\
\hline $\begin{array}{l}\text { 42. Incorporar critérios socioambiental na estratégia da organização (Ethos, } \\
\text { 2013). }\end{array}$ & 0 & 0 & 0 & 0 & 2,25 & 0 & 0 & 0 & 0 & 0 & 0 & 0 & 0 & 0 & 0 & 0 & 0 & 0 & 0 & 0 & 0 & 0 & 0,1 \\
\hline $\begin{array}{l}\text { 43. Comunicar a toda a organização e outras partes interessadas a } \\
\text { importância de considerar os aspectos socioambientais (Ethos, 2013). }\end{array}$ & 0 & 0 & 0 & 0 & 2,25 & 0 & 0 & 0 & 0 & 0 & 0 & 0 & 0 & 0 & 0 & 0 & 0 & 0 & 0 & 0 & 0 & 0 & 0,1 \\
\hline $\begin{array}{l}\text { 44. A responsabilidade socioambiental deve ser repassada em toda a cadeia } \\
\text { produtiva (Ethos, 2013), (ISE, 2013) e (GRI). }\end{array}$ & 0 & 0 & 0 & 0 & 2,25 & 0 & 0 & 0 & 0 & 0 & 0 & 0 & 0 & 0 & 0 & 0 & 0 & 0 & 0 & 0 & 0 & 0 & 0,1 \\
\hline $\begin{array}{l}\text { 45. Possuir normas de seleção e avaliação de fornecedores que contemplam } \\
\text { critérios específicos de responsabilidade socioambiental (Ethos, 2013), (ISE, } \\
2013 \text { ) e (GRI). }\end{array}$ & 0 & 0 & 0 & 0 & 2,25 & 0 & 0 & 0 & 0 & 0 & 0 & 0 & 0 & 0 & 0 & 0 & 0 & 0 & 0 & 0 & 0 & 0 & 0,1 \\
\hline $\begin{array}{l}\text { 46. Produzir relatórios periódicos com evidências de que questões } \\
\text { relacionadas à responsabilidade socioambiental empresarial estão sendo } \\
\text { cumpridas e implementadas em sua cadeia produtiva (Ethos, 2013). }\end{array}$ & 0 & 0 & 0 & 0 & 0 & 0 & 0 & 0 & 0 & 0 & 0 & 0 & 0 & 0 & 0 & 0 & 0 & 0 & 0 & 0 & 0 & 0 & 0 \\
\hline $\begin{array}{l}\text { 47. Caso necessário treinar os fornecedores para que se adequem as } \\
\text { questões relacionadas a responsabilidade socioambiental (Ethos, 2013) e } \\
\text { (ISE, 2013). }\end{array}$ & 0 & 0 & 0 & 0 & 0 & 0 & 0 & 0 & 0 & 0 & 0 & 0 & 0 & 0 & 2,25 & 0 & 0 & 0 & 0 & 0 & 0 & 0 & 0,1 \\
\hline $\begin{array}{l}\text { 48. Participar de comitês/conselhos locais ou regionais para discutirem a } \\
\text { questão ambiental com o governo e a comunidade (Ethos, 2013). }\end{array}$ & 0 & 0 & 0 & 0 & 0 & 0 & 0 & 0 & 0 & 0 & 0 & 0 & 0 & 0 & 0 & 0 & 0 & 0 & 0 & 0 & 0 & 0 & 0 \\
\hline $\begin{array}{l}\text { 49. Desenvolver campanhas, apoiar ou participar de projetos educacionais } \\
\text { em parceria com organizações não governamentais e ambientalistas, } \\
\text { exercendo liderança social em favor dessa causa (Ethos, 2013). }\end{array}$ & 0 & 0 & 0 & 0 & 0 & 0 & 0 & 0 & 0 & 0 & 0 & 0 & 0 & 0 & 0 & 0 & 0 & 0 & 0 & 0 & 0 & 0 & 0 \\
\hline $\begin{array}{l}\text { 50. Disponibilizar suporte técnico aos consumidores finais com vistas ao uso } \\
\text { sustentável de seus produtos ou serviços (ISE, 2013). }\end{array}$ & 0 & 0 & 0 & 0 & 0 & 0 & 0 & 0 & 0 & 0 & 0 & 0 & 0 & 0 & 0 & 0 & 0 & 0 & 0 & 0 & 0 & 0 & 0 \\
\hline $\begin{array}{l}\text { 51. Fornecer aos consumidores e clientes informações detalhadas sobre } \\
\text { danos socioambientais resultantes do uso e na destinação final de seus } \\
\text { produtos (Ethos, 2013). }\end{array}$ & 0 & 0 & 0 & 0 & 0 & 0 & 0 & 0 & 0 & 0 & 0 & 0 & 0 & 0 & 0 & 0 & 0 & 0 & 0 & 0 & 0 & 0 & 0 \\
\hline $\begin{array}{l}\text { 52. Divulgar informações a respeito dos aspectos e impactos ambientais } \\
\text { gerados pela organização (ISE, 2013). }\end{array}$ & 0 & 0 & 0 & 0 & 0 & 0 & 0 & 0 & 0 & 0 & 0 & 0 & 0 & 0 & 0 & 0 & 0 & 0 & 0 & 0 & 0 & 0 & 0 \\
\hline $\begin{array}{l}\text { 53. Mecanismos de Queixas e Reclamações Relativas a Impactos Ambientais } \\
\text { (ISE, 2013) }\end{array}$ & 0 & 0 & 0 & 0 & 0 & 0 & 0 & 0 & 0 & 0 & 0 & 0 & 0 & 0 & 0 & 0 & 0 & 0 & 0 & 0 & 0 & 0 & 0 \\
\hline MÉDIA - Requisitos da ISO 9001 & 0 & 0 & 0 & 0 & 0,87 & 0 & 0 & 0 & 0 & 0 & 0 & 0 & 0 & 0 & 0,17 & 0 & 0 & 0 & 0 & 0 & 0 & 0 & 0,05 \\
\hline
\end{tabular}


Apêndice 7. Matriz de Relação Consolidada ISO 9001 - Dimensão Socioeconômica.

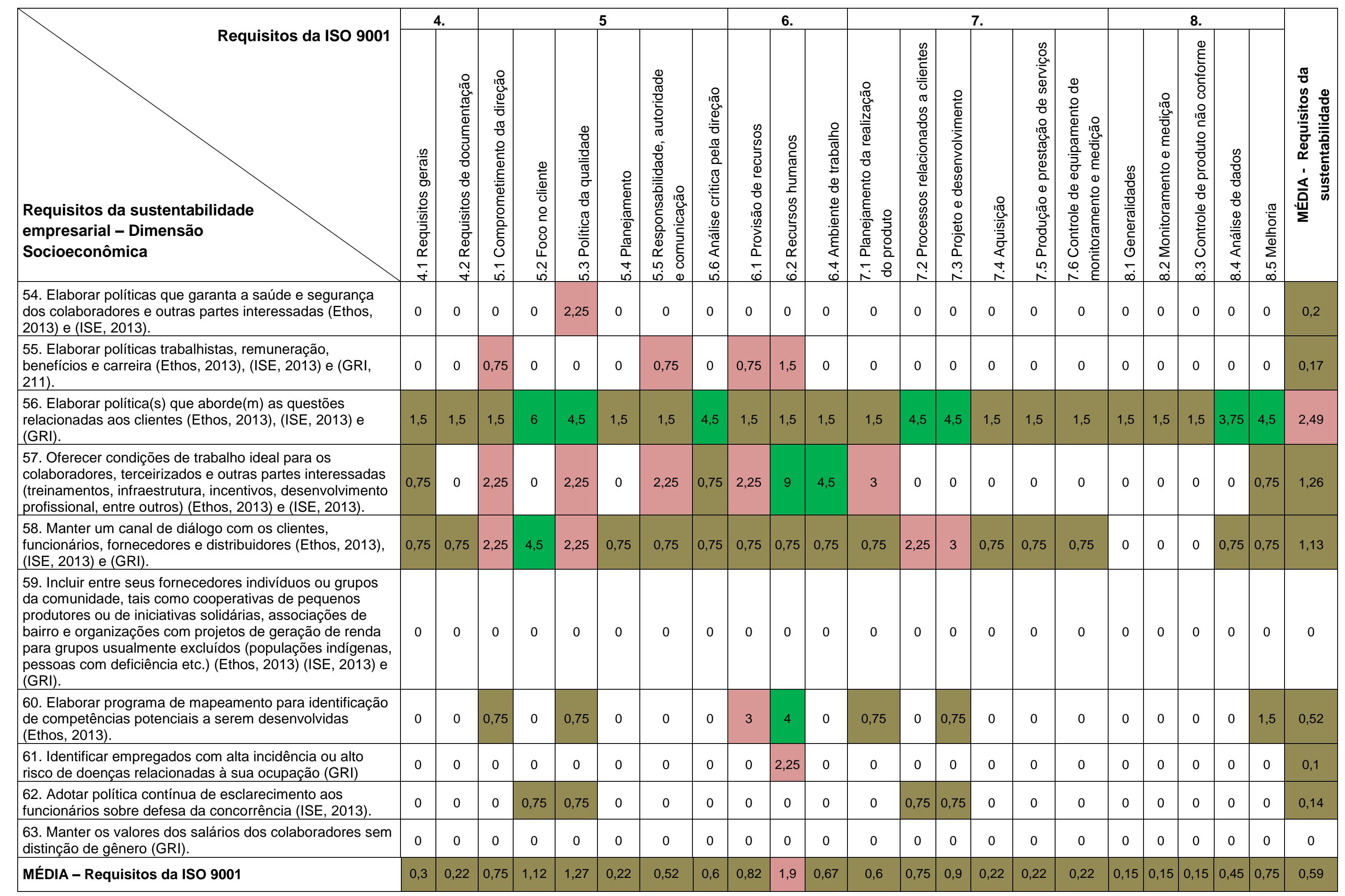


Apêndice 8. Matriz de Relação Consolidada ISO 9001 - Dimensão Econômico - ambiental.

\begin{tabular}{|c|c|c|c|c|c|c|c|c|c|c|c|c|c|c|c|c|c|c|c|c|c|c|c|}
\hline \multirow[b]{2}{*}{$\begin{array}{l}\text { Requisitos da sustentabilidade } \\
\text { empresarial - Dimensão econômica - } \\
\text { ambiental }\end{array}$} & \multicolumn{2}{|c|}{4.} & \multicolumn{6}{|c|}{5} & \multicolumn{3}{|c|}{6.} & \multicolumn{6}{|c|}{7.} & \multicolumn{5}{|c|}{8.} & \\
\hline & 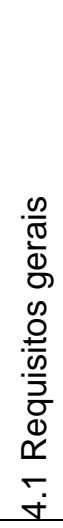 & 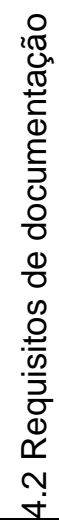 & 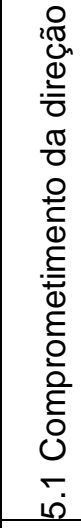 & 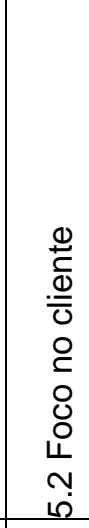 & 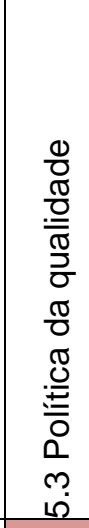 & 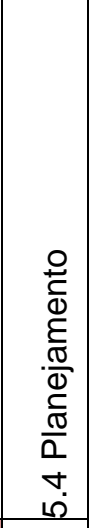 & 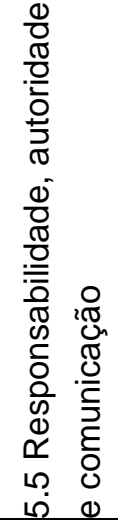 & 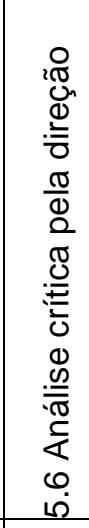 & 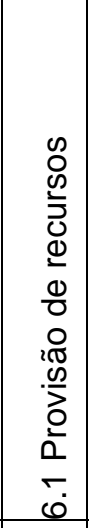 & 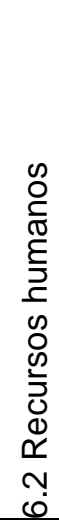 & 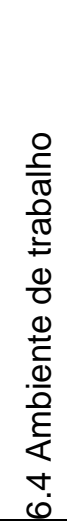 & 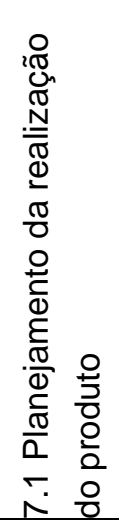 & 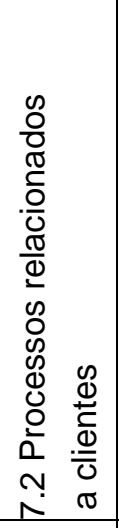 & 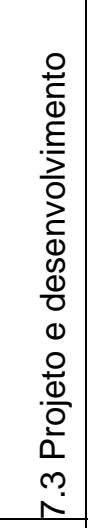 & 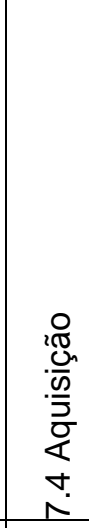 & $\begin{array}{l}\frac{2}{0} \\
0 \\
0 \\
0 \\
0 \\
0 \\
0 \\
\frac{\pi}{0} \\
0 \\
0 \\
0 \\
0 \\
0 \\
0 \\
20 \\
0 \\
0 \\
0 \\
0 \\
0 \\
10 \\
1\end{array}$ & 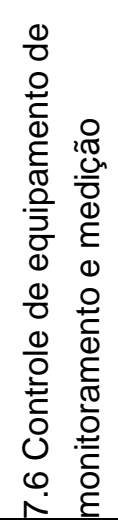 & 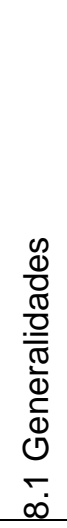 & 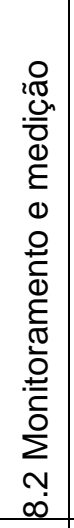 & \begin{tabular}{l}
0 \\
0 \\
0 \\
0 \\
0 \\
20 \\
\multicolumn{1}{c}{} \\
0 \\
0 \\
$\frac{1}{0}$ \\
0 \\
0 \\
0 \\
0 \\
0 \\
0 \\
0 \\
0 \\
0 \\
0 \\
0 \\
0 \\
$\infty$ \\
$\infty$
\end{tabular} & 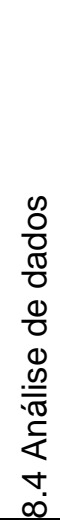 & 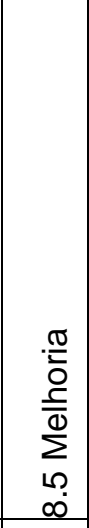 & \\
\hline $\begin{array}{l}\text { 64. Desenvolver programas internos de melhoramento ambiental } \\
\text { (Ethos, 2013). }\end{array}$ & 0 & 0 & 0 & 0 & 2,25 & 0 & 0 & 0 & 0 & 0 & 0 & 0 & 0 & 0 & 0 & 0 & 0 & 0 & 0 & 0 & 0 & 0 & 0,1 \\
\hline 65. Possuir programas de gerenciamento de resíduos (Ethos, 2013). & 0 & 0 & 0 & 0 & 0 & 0 & 0 & 0 & 0 & 0 & 0 & 0 & 0 & 2,25 & 0 & 0 & 0 & 0 & 0 & 0 & 0 & 0 & 0,1 \\
\hline $\begin{array}{l}\text { 66. Possuir programas específicos para verificar a origem e a cadeia } \\
\text { de produção dos insumos madeireiros e florestais utilizados em sua } \\
\text { operação diária e/ou processo produtivo (Ethos, 2013). }\end{array}$ & 0 & 0 & 0 & 0 & 0 & 0 & 0 & 0 & 0 & 0 & 0 & 0 & 0 & 0 & 2,25 & 0 & 0 & 0 & 0 & 0 & 0 & 0 & 0,1 \\
\hline 67. Priorizar políticas preventivas (Ethos, 2013). & 0 & 0 & 0,75 & 0,75 & 0,75 & 0,75 & 0,75 & 0,75 & 0,75 & 0 & 0 & 0,75 & 0 & 0,75 & 0 & 0 & 0 & 0 & 0 & 0 & 0 & 6,75 & 0,62 \\
\hline $\begin{array}{l}\text { 68. Possuir políticas e sistema de monitoramento visando o aumento } \\
\text { da qualidade ambiental (Ethos, 2013). }\end{array}$ & 0 & 0 & 0 & 0 & 0 & 0 & 0 & 0 & 0 & 0 & 0 & 0 & 0 & 0 & 0 & 0 & 0 & 0 & 0 & 0 & 0 & 0 & 0 \\
\hline $\begin{array}{l}\text { 69. Participar da destinação final dos produtos e processos pós- } \\
\text { consumo (Ethos, 2013). }\end{array}$ & 0 & 0 & 0 & 0,75 & 0,75 & 0 & 0 & 0 & 0 & 0 & 0 & 0,75 & 0 & 4,5 & 0 & 0 & 0 & 0 & 0 & 0 & 0 & 0 & 0,31 \\
\hline $\begin{array}{l}\text { 70. Sem alterar seus padrões tecnológicos atuais, procurar reduzir o } \\
\text { consumo de energia, de água, de produtos tóxicos e de matérias- } \\
\text { primas e implantar processos para a destinação adequada de resíduos } \\
\text { (Ethos, 2013). }\end{array}$ & 0 & 0 & 0,75 & 0 & 0,75 & 0 & 0 & 0 & 0,75 & 0 & 0 & 0,75 & 0 & 5,25 & 0 & 0 & 0 & 0 & 0 & 0 & 0 & 0 & 0,38 \\
\hline 71. Considerar os passivos ambientais (ISE, 2013). & 0 & 0 & 0 & 0 & 0 & 0 & 0 & 0 & 0 & 0 & 0 & 0 & 0 & 2,25 & 0 & 0 & 0 & 0 & 0 & 0 & 0 & 0 & 0,1 \\
\hline $\begin{array}{l}\text { 72. Possuir seguro para degradação ambiental decorrente de } \\
\text { acidentes em suas operações (ISE, 2013). }\end{array}$ & 0 & 0 & 0 & 0 & 0 & 0 & 0 & 0 & 0 & 0 & 0 & 0 & 0 & 0 & 0 & 0 & 0 & 0 & 0 & 0 & 0 & 0 & 0 \\
\hline $\begin{array}{l}\text { 73. Considera a abordagem baseado no ciclo de vida dos produtos } \\
\text { (ISE, 2013). }\end{array}$ & 0 & 0 & 0 & 0,75 & 0,75 & 0 & 0,75 & 0 & 0 & 0 & 0 & 0,75 & 0,75 & 5,25 & 0 & 0 & 0 & 0 & 0 & 0 & 0 & 0 & 0,41 \\
\hline $\begin{array}{l}\text { 74. Possuir processo para medir, monitorar e auditar periodicamente } \\
\text { os aspectos ambientais significativos relacionados ao consumo de } \\
\text { recursos naturais e à produção de resíduos e dejetos, estabelecendo } \\
\text { periodicamente novas metas (Ethos, 2013), (ISE, 2013). }\end{array}$ & 0 & 0 & 0 & 0 & 0 & 0 & 0 & 0 & 0 & 0 & 0 & 0 & 0 & 2,25 & 0 & 0 & 0 & 0 & 0 & 0 & 0 & 0 & 0,1 \\
\hline $\begin{array}{l}\text { 75. Monitorar o consumo de recursos naturais na cadeia produtiva } \\
\text { (ISE, 2013). }\end{array}$ & 0 & 0 & 0 & 0 & 1,5 & 0 & 1,5 & 0 & 1,5 & 0 & 0 & 1,5 & 1,5 & 2,25 & 0 & 0 & 0 & 0 & 0 & 0 & 0 & 0 & 0,44 \\
\hline $\begin{array}{l}\text { 76. Considerar iniciativas tais como "ecodesign" ou DfE (Desing for } \\
\text { Environment) (ISE, 2013). }\end{array}$ & 0 & 0 & 0 & 0,75 & 0,75 & 0 & 0 & 0 & 0,75 & 0 & 0 & 0,75 & 0,75 & 3 & 0 & 0 & 0 & 0 & 0 & 0 & 0 & 0 & 0,31 \\
\hline $\begin{array}{l}\text { 77. As estratégias envolvendo a definição de produtos e/ou serviços } \\
\text { oferecidos pela companhia e/ou por suas controladas ou os projetos } \\
\text { de Pesquisa e Desenvolvimento elaborados pelas mesmas preveem } \\
\text { planos para reposicionamento (refere-se à mudança no mix de } \\
\text { produtos/serviços do portfólio e/ou público-alvo) em função das } \\
\text { potenciais mudanças nos padrões de oferta e demanda de recursos } \\
\text { naturais (ISE, 2013). }\end{array}$ & 0 & 0 & 0 & 0,75 & 0,75 & 0 & 0 & 0 & 0,75 & 0 & 0 & 0,75 & 0,75 & 5,25 & 0 & 0 & 0 & 0 & 0 & 0 & 0 & 0 & 0,41 \\
\hline MÉDIA - Requisitos da ISO 9001 & 0 & 0 & 0,11 & 0,27 & 0,59 & 0,05 & 0,21 & 0,05 & 0,32 & 0 & 0 & 0,43 & 0,27 & 2,36 & 0,16 & 0 & 0 & 0 & 0 & 0 & 0 & 0,48 & 0,24 \\
\hline
\end{tabular}


Apêndice 9. Matriz de Relação Consolidada ISO 9001 - Dimensão ambiental - social - econômica.

\begin{tabular}{|c|c|c|c|c|c|c|c|c|c|c|c|c|c|c|c|c|c|c|c|c|c|c|c|}
\hline \multirow[b]{2}{*}{$\begin{array}{l}\text { Requisitos da sustentabilidade } \\
\text { empresarial - Dimensão Econômica } \\
\text { ambiental - social }\end{array}$} & \multicolumn{2}{|c|}{4.} & \multicolumn{6}{|c|}{5} & \multicolumn{3}{|c|}{6.} & \multicolumn{6}{|c|}{7.} & \multicolumn{5}{|c|}{8.} & \multirow[b]{2}{*}{ 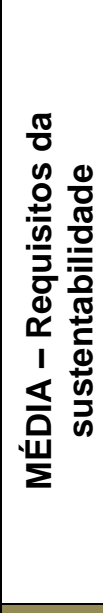 } \\
\hline & 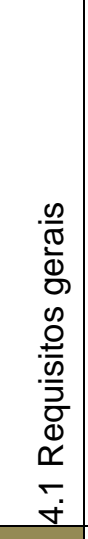 & 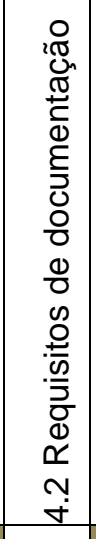 & 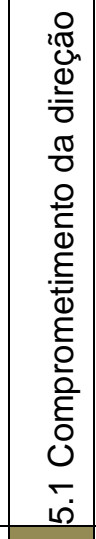 & 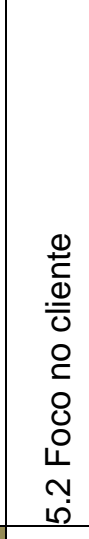 & 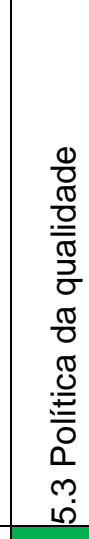 & 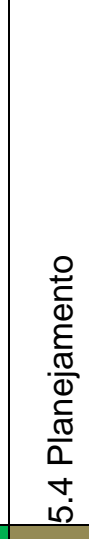 & 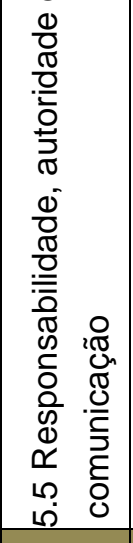 & 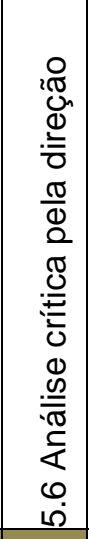 & 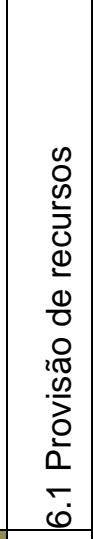 & 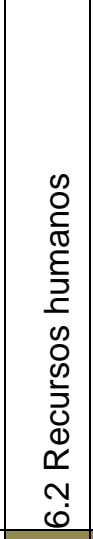 & 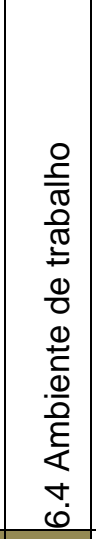 & 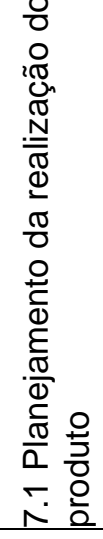 & 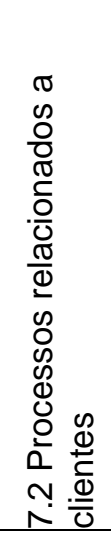 & 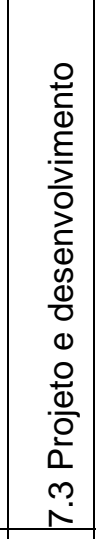 & 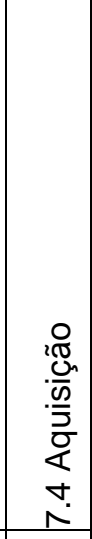 & 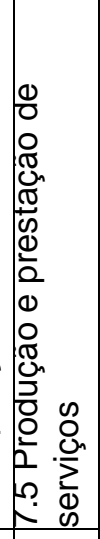 & 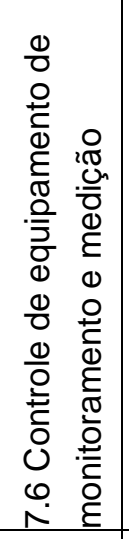 & $\begin{array}{l}0 \\
\frac{0}{0} \\
\frac{\pi}{0} \\
\frac{0}{\sqrt{0}} \\
\frac{\pi}{0} \\
\frac{0}{0} \\
\mathbb{0} \\
\mathbb{0} \\
\frac{\infty}{0}\end{array}$ & 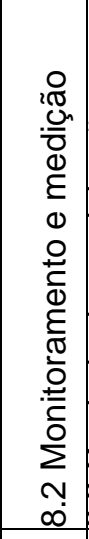 & 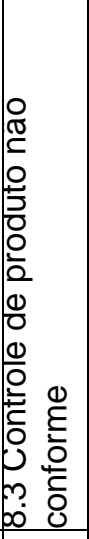 & 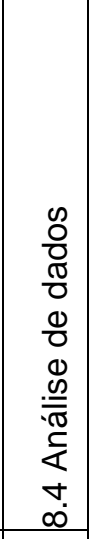 & 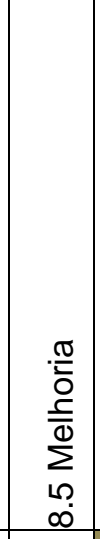 & \\
\hline 78. Elaborar política de comunicação (Ethos, 2013). & 0,75 & 0 & 0,75 & 0 & 6,75 & 0,75 & 0,75 & 0,75 & 0 & 0,75 & 0,75 & 0 & 0 & 0 & 0 & 0 & 0 & 0 & 0 & 0 & 0 & 0 & 0,55 \\
\hline 79. Assumir uma postura ética (Ethos, 2013). & 0 & 0 & 2,25 & 3 & 1,5 & 0,75 & 0,75 & 0 & 0 & 1,5 & 0,75 & 0 & 0 & 0 & 0 & 0 & 0 & 0 & 0 & 0 & 0 & 0 & 0,48 \\
\hline $\begin{array}{l}\text { 80. Identificar as partes interessadas e conhecer o contexto em } \\
\text { que cada parte está inserida para que as mesmas possam } \\
\text { auxiliar na mitigação dos impactos socioambientais envolvidos } \\
\text { em cada contexto (Ethos, 2013) e (ISE, 2013). }\end{array}$ & 0 & 0 & 0 & 0 & 0 & 0 & 0 & 0 & 0 & 0 & 0 & 0 & 0 & 2,25 & 0 & 0 & 0 & 0 & 0 & 0 & 0 & 0 & 0,1 \\
\hline $\begin{array}{l}\text { 81. Manter o diálogo com as partes interessadas (Ethos, 2013) } \\
\text { (ISE, 2013) e (GRI). }\end{array}$ & 0,75 & 0 & $0,75 \mid$ & 1,5 & 0,75 & 0 & 0,75 & 0,75 & 0,75 & $0,75 \mid$ & $0,75 \mid$ & 0 & 0 & 0,75 & 0,75 & $0,75 \mid$ & 0 & 0 & 0 & 0 & 0 & 0,75 & 0,48 \\
\hline $\begin{array}{l}\text { 82. Monitorar os impactos causados por suas atividades na } \\
\text { comunidade de entorno (Ethos, 2013). }\end{array}$ & 0 & 0 & 0,75 & 0 & 0,75 & 0 & 0,75 & 0 & 0 & 0,75 & 0 & 0 & 0 & 2,25 & 0 & 0 & 0 & 0 & 0 & 0 & 0 & 0,75 & 0,27 \\
\hline $\begin{array}{l}\text { 83. Possuir conselho ou responsável formal por questões éticas } \\
\text { internas e externas e garantir a gerência eficaz (Ethos, 2013) e } \\
\text { (ISE, 2013). }\end{array}$ & 0 & 0 & 0,75 & 0 & 0,75 & 0 & 0,75 & 0 & 0 & 0,75 & 0 & 0 & 0 & 2,25 & 0 & 0 & 0 & 0 & 0 & 0 & 0 & 0,75 & 0,27 \\
\hline 84. Não praticar concorrência desleal (Ethos, 2013) e (GRI). & 0 & 0 & 1,5 & 0,75 & 0,75 & 0 & 0 & 0 & 0 & 0 & 0 & 0 & 0 & 0 & 0 & 0 & 0 & 0 & 0 & 0 & 0 & 0 & 0,14 \\
\hline $\begin{array}{l}\text { 85. Cumprir a legislação e pagamentos de tributos (Ethos, 2013) } \\
\text { e (ISE, 2013). }\end{array}$ & 0 & 0 & 1,5 & 0 & 5,25 & 0 & 0,75 & 0,75 & 0 & 0 & 0 & 0 & 0 & 0 & 0 & 0 & 0 & 0 & 0 & 0 & 0 & 0 & 0,38 \\
\hline $\begin{array}{l}\text { 86. Comunicar o compromisso com o desenvolvimento } \\
\text { sustentável (ISE, 2013). }\end{array}$ & 0 & 0 & 0,75 & 0 & 3,75 & 0,75 & 0,75 & 0,75 & 0,75 & $0,75 \mid$ & 0 & 0 & 0 & 0 & 0 & 0 & 0 & 0 & 0 & 0 & 0 & 0,75 & 0,41 \\
\hline 87. Definir responsabilidades e autoridades (ISE, 2013). & 0 & 0 & 1,5 & 0 & 1,5 & 1,5 & 1,5 & 1,5 & 1,5 & 1,5 & 0 & 0 & 0 & 2,25 & 0 & 0 & 0 & 0 & 0 & 0 & 0 & 1,5 & 0,65 \\
\hline $\begin{array}{l}\text { 88. Existir processos e procedimentos implementados para } \\
\text { gestão de oportunidades corporativas que considere aspectos } \\
\text { socioambientais de curto, médio e longo prazo (ISE, 2013). }\end{array}$ & 0 & 0 & 0 & 0 & 0 & 0 & 0 & 0 & 0 & 0 & 0 & 0 & 0 & 2,25 & 0 & 0 & 0 & 0 & 0 & 0 & 0 & 0 & 0,1 \\
\hline $\begin{array}{l}\text { 89. Possuir plano de contingência que considere desastres } \\
\text { naturais, impactos ambientais, impactos sociais, impactos em } \\
\text { infraestrutura/operacionais (incluindo TI) (ISE, 2013). }\end{array}$ & 0 & 0 & 0 & 0 & 0 & 0 & 0 & 0 & 0 & 0 & 0 & 0 & 0 & 0 & 0 & 0 & 0 & 0 & 0 & 0 & 0 & 0 & 0 \\
\hline MÉDIA - Requisitos da ISO 9001 & 0,13 & 0,00 & 0,88 & 0,44 & 1,81 & 0,31 & 0,56 & 0,38 & 0,25 & $\mid 0,56$ & $|0,19|$ & 0,00 & 0,00 & $\mid 1,00$ & 0,06 & $|0,06|$ & 0,00 & 0,00 & 0,00 & 0,00 & 0,00 & 0,38 & 0,32 \\
\hline
\end{tabular}


Apêndice 10. Matriz de Relação Consolidada ISO 14001 - Dimensão Social.

\begin{tabular}{|c|c|c|c|c|c|c|c|c|c|c|c|c|c|c|c|c|c|c|c|}
\hline \multirow[b]{2}{*}{$\begin{array}{l}\text { Requisitos da sustentabilidade } \\
\text { empresarial - Dimensão social }\end{array}$} & \multirow[b]{2}{*}{ 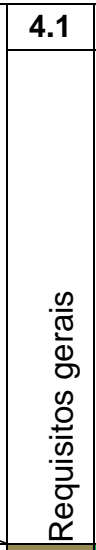 } & \multirow[b]{2}{*}{ 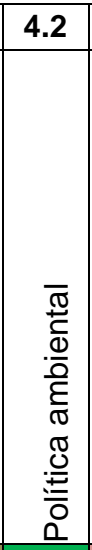 } & \multicolumn{3}{|c|}{4.3} & \multicolumn{7}{|c|}{4.4} & \multicolumn{6}{|c|}{4.5} & \multirow[b]{2}{*}{ 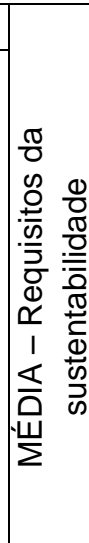 } \\
\hline & & & 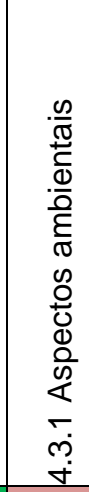 & 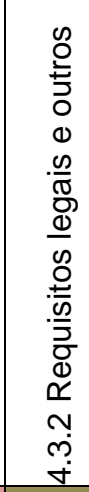 & 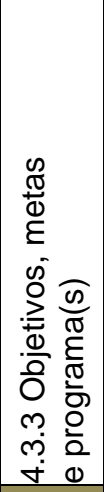 & 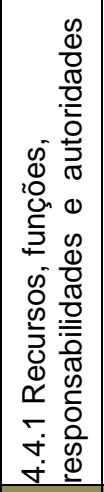 & 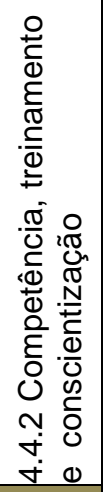 & 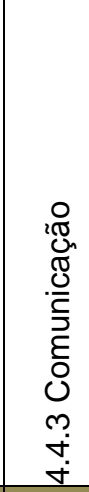 & 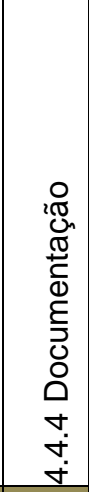 & 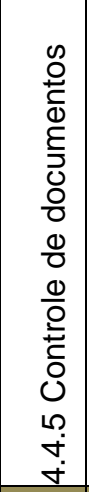 & 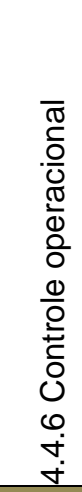 & 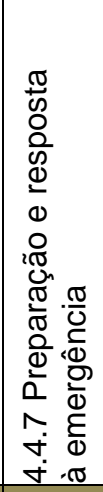 & 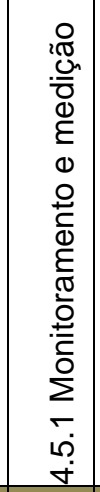 & 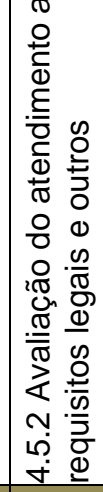 & 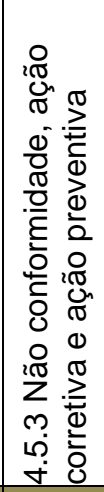 & 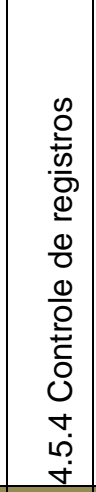 & 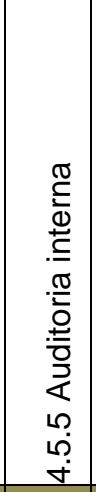 & 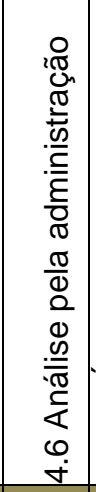 & \\
\hline $\begin{array}{l}\text { 1. Elaborar política para que os indicadores/dados/informações advindos do processo de } \\
\text { diálogo e engajamento das partes interessadas sejam, preservadas (quando confidencial), } \\
\text { comparáveis, confiáveis, relevantes e compreensíveis por suas partes interessadas } \\
\text { (Ethos, 2013) e (ISE, 2013). }\end{array}$ & 0,75 & 6,75 & 3 & 0,75 & 0,75 & 0,75 & 0,75 & 0,75 & 0,75 & 0,75 & 0,75 & 0,75 & 0,75 & 0,75 & 0,75 & 0,75 & 0,75 & 0,75 & 1,21 \\
\hline $\begin{array}{l}\text { 2. Valorizar a diversidade, equidade e não discriminação ( racial, gênero, opção sexual ou } \\
\text { qualquer outra forma de discriminação) (Ethos, 2013), (ISE, 2013) e (GRI). }\end{array}$ & 0,75 & 6,75 & 0,75 & 1,5 & 2,25 & 0,75 & 2,25 & 0,75 & 0,75 & 0,75 & 0,75 & 0,75 & 0,75 & 0,75 & 0,75 & 0,75 & 0,75 & 2,25 & 1,38 \\
\hline $\begin{array}{l}\text { 3.Considerar a responsabilidade social na cadeia de fornecimento (Ethos, 2013) e (ISE, } \\
\text { 2013). }\end{array}$ & 0,75 & 5,25 & 0,75 & 2,25 & 0,75 & 0,75 & 0,75 & 0,75 & 0,75 & 0,75 & 0,75 & 0,75 & 0,75 & 0,75 & 0,75 & 0,75 & 0,75 & 2,25 & 1,17 \\
\hline 4. Engajar as partes interessadas (Ethos, 2013) e (ISE, 2013). & 0,75 & 2,25 & 0,75 & 0,75 & 2,25 & 0,75 & 0,75 & 2,25 & 0,75 & 0,75 & 0,75 & 0,75 & 0,75 & 0,75 & 0,75 & 0,75 & 0,75 & 2,25 & 1,08 \\
\hline $\begin{array}{l}\text { 5. Participar do processo de elaboração, avaliação, implantação ou monitoramento de } \\
\text { políticas públicas (Ethos, 2013), (ISE, 2013) e (GRI). }\end{array}$ & 0 & 0 & 0 & 0 & 1,5 & 1,5 & 0 & 0 & 0 & 0 & 0 & 0 & 0 & 0 & 0 & 0 & 0 & 0 & 0,17 \\
\hline $\begin{array}{l}\text { 6. Apoiar, patrocinar e desenvolver projetos, programas, campanhas e pesquisas } \\
\text { científicas (Ethos, 2013), (ISE, 2013) e (GRI). }\end{array}$ & 0 & 2,25 & 0 & 0 & 3,75 & 1,5 & 0 & 0 & 0 & 0 & 0 & 0 & 0 & 0 & 0 & 0 & 0 & 0 & 0,42 \\
\hline 7. Oferecer oportunidade de trabalho para grupos vulneráveis (Ethos, 2013). & 0 & 0 & 0 & 0 & 0 & 1,5 & 0 & 0 & 0 & 0 & 0 & 0 & 0 & 0 & 0 & 0 & 0 & 0 & 0,08 \\
\hline $\begin{array}{l}\text { 8. Estimular os funcionários a cumprirem os valores e princípios éticos da organização } \\
\text { (Ethos, 2013). }\end{array}$ & 2,25 & 2,25 & 0,75 & 1,5 & 0,75 & 0,75 & 5,25 & 0,75 & 0,75 & 0,75 & 0,75 & 0,75 & 0,75 & 0,75 & 0,75 & 0,75 & 0,75 & 2,25 & 1,29 \\
\hline 9. Garantir o atendimento dos direitos humanos (GRI). & 2,25 & 5,25 & 0,75 & 3 & 6,75 & 0,75 & 0,75 & 0,75 & 0,75 & 0,75 & 0,75 & 0,75 & 0,75 & 0,75 & 0,75 & 0,75 & 0,75 & 2,25 & 1,63 \\
\hline $\begin{array}{l}\text { 10.Elaborar programas de aconselhamento sobre o planejamento de carreiras, de forma a } \\
\text { auxiliar os empregados na reflexão sobre suas funções e identificação de objetivos em } \\
\text { longo prazo (Ethos, 2013). }\end{array}$ & 0,75 & 0,75 & 0 & 0 & 1,5 & 2,25 & 2,25 & 0 & 0 & 0 & 0 & 0 & 0 & 0 & 0 & 0 & 0 & 0 & 0,42 \\
\hline $\begin{array}{l}\text { 11.Elaborar programa sistemático de preparação interna, oferecendo oportunidades de } \\
\text { aproveitamento da capacidade de trabalho dos aposentados (Ethos, 2013). }\end{array}$ & 0 & 0 & 0 & 0 & 0 & 2,25 & 0,75 & 0 & 0 & 0 & 0 & 0 & 0 & 0 & 0 & 0 & 0 & 0 & 0,17 \\
\hline $\begin{array}{l}\text { 12.Elaborar programa para empregar, na medida do possível, o maior número de } \\
\text { moradores do local em que está inserida, dando-lhes formação, com o objetivo de } \\
\text { aumentar os níveis de qualificação daquela comunidade, em cooperação com sindicatos, } \\
\text { ONGs, representantes da comunidade ou autoridades públicas competentes (Ethos, 2013) } \\
\text { e (ISE, 2013). }\end{array}$ & 0 & 4,5 & 0 & 0 & 0,75 & 0,75 & 0,75 & 0 & 0 & 0 & 0 & 0 & 0 & 0 & 0 & 0 & 0 & 0 & 0,38 \\
\hline $\begin{array}{l}\text { 13. Elaborar programa específico de contratação de pessoas com deficiência (Ethos, } \\
\text { 2013). }\end{array}$ & 0 & 0,75 & 0 & 3 & 1,5 & 0,75 & 0 & 0 & 0 & 0 & 0 & 0 & 0 & 0 & 0 & 0 & 0 & 0 & 0,33 \\
\hline $\begin{array}{l}\text { 14. Identificar os tipos e taxas de lesões, doenças ocupacionais, dias perdidos, } \\
\text { absenteísmo e número de óbitos relacionados ao trabalho, discriminados por região e } \\
\text { gênero (GRI). }\end{array}$ & 0 & 0 & 0 & 2,25 & 1,5 & 1,5 & 0 & 0 & 0 & 0 & 0 & 0 & 0 & 0 & 0 & 0 & 0 & 0,75 & 0,33 \\
\hline $\begin{array}{l}\text { 15. Estabelecer acordos formais entre as empresas, sindicatos e colaboradores para } \\
\text { manter o direito dos colaboradores (GRI). }\end{array}$ & 0 & 0 & 0 & 2,25 & 1,5 & 1,5 & 0 & 0,75 & 0 & 0 & 0 & 0 & 0 & 0 & 0 & 0 & 0 & 0,75 & 0,38 \\
\hline MÉDIA - Requisitos ISO 14001 & 0,55 & 2,45 & 0,45 & 1,15 & 1,7 & 1,2 & 0,95 & 0,45 & 0,3 & 0,3 & 0,3 & 0,3 & 0,3 & 0,3 & 0,3 & 0,3 & 0,3 & 0,9 & 0,7 \\
\hline
\end{tabular}


Apêndice 11. Matriz de Relação Consolidada ISO 14001 - Dimensão Ambiental.

\begin{tabular}{|c|c|c|c|c|c|c|c|c|c|c|c|c|c|c|c|c|c|c|c|}
\hline & 4.1 & 4.2 & & 4.3 & & & & & 4.4 & & & & & & 4.5 & & & & \\
\hline $\begin{array}{l}\text { Requisitos da sustentabilidade } \\
\text { empresarial - Dimensão ambiental }\end{array}$ & 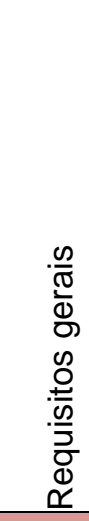 & 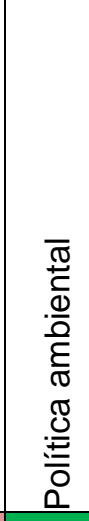 & 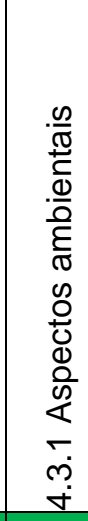 & 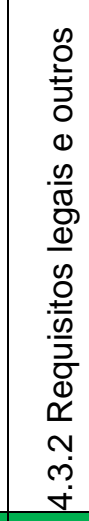 & 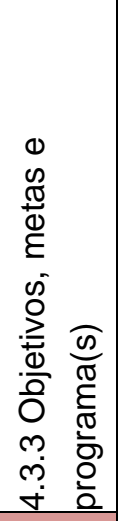 & 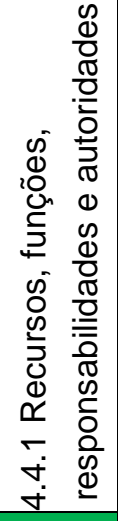 & 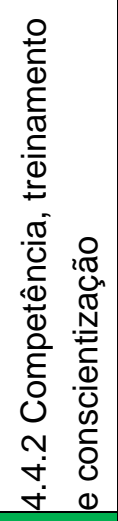 & 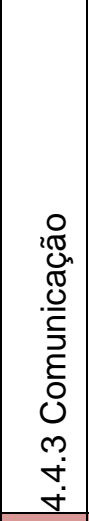 & 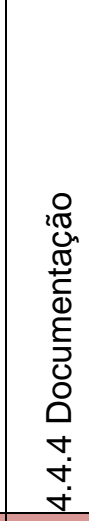 & 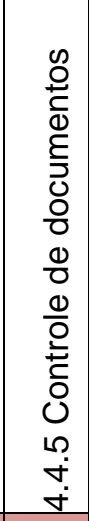 & 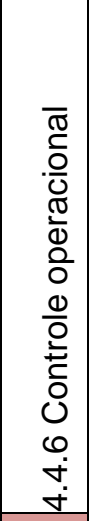 & 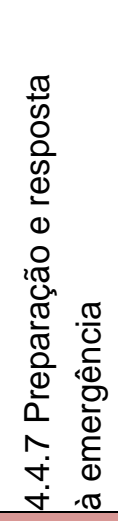 & 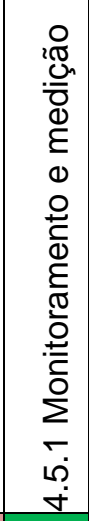 & 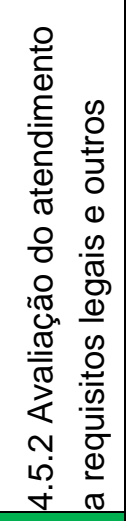 & 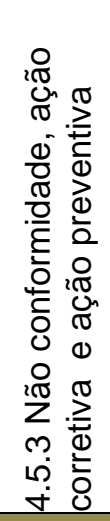 & 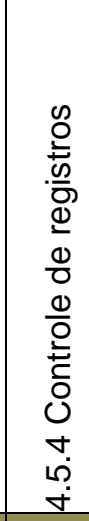 & 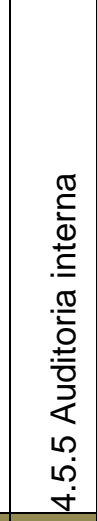 & 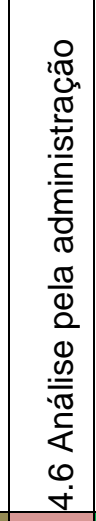 & 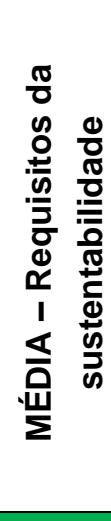 \\
\hline $\begin{array}{l}\text { 16. Garantir a preservação das Áreas de Preservação Permanente (APP) } \\
\text { (ISE, 2013). }\end{array}$ & 2,25 & 3,75 & 5,25 & 6,75 & 2,25 & 3,75 & 5,25 & 2,25 & 2,25 & 2,25 & 2,25 & 2,25 & 5,25 & 5,25 & 0,75 & 0,75 & 0,75 & 2,25 & 3,08 \\
\hline 17. Delimitar a área de Reserva Legal em situações aplicáveis (ISE, 2013). & 0,75 & 2,25 & 5,25 & 6,75 & 3 & 2,25 & 5,25 & 0,75 & 3 & 3 & 0,75 & 0,75 & 5,25 & 5,25 & 0,75 & 0,75 & 0,75 & 2,25 & 2,71 \\
\hline $\begin{array}{l}\text { 18. Possuir todas as licenças necessárias no licenciamento ambiental (ISE, } \\
\text { 2013). }\end{array}$ & 0,75 & 2,25 & 5,25 & 6,75 & 3 & 2,25 & 0,75 & 0,75 & 5,25 & 5,25 & 0,75 & 0,75 & 0,75 & 0,75 & 0,75 & 0,75 & 0,75 & 0,75 & 2,13 \\
\hline 19. Considerar a questão das mudanças climáticas (ISE, 2013). & 0,75 & 3,75 & 4,5 & 4,5 & 3,75 & 1,5 & 1,5 & 0,75 & 0,75 & 0,75 & 0,75 & 0,75 & 0,75 & 1,5 & 0,75 & 0,75 & 0,75 & 0,75 & 1,63 \\
\hline $\begin{array}{l}\text { 21. Contribuir para a preservação da biodiversidade por meio de políticas } \\
\text { específicas (Ethos, 2013) e (ISE, 2013). }\end{array}$ & 0,75 & 7,5 & 4,5 & 3 & 3,75 & 1,5 & 1,5 & 0,75 & 0,75 & 0,75 & 0,75 & 0,75 & 1,5 & 1,5 & 1,5 & 0,75 & 0,75 & 0,75 & 1,83 \\
\hline 22. Possuir área ou comitê responsável pelo meio ambiente (Ethos, 2013). & 2,25 & 4,5 & 2,25 & 2,25 & 2,25 & 6,75 & 0,75 & 0,75 & 0,75 & 0,75 & 0,75 & 0,75 & 0,75 & 0,75 & 0,75 & 0,75 & 0,75 & 2,25 & 1,71 \\
\hline $\begin{array}{l}\text { 23. Exigir estudos de impacto ambiental em toda a cadeia produtiva (Ethos, } \\
\text { 2013). }\end{array}$ & 0,75 & 2,25 & 6,75 & 4,5 & 2,25 & 2,25 & 2,25 & 0,75 & 0,75 & 0,75 & 0,75 & 0,75 & 0,75 & 0,75 & 0,75 & 0,75 & 0,75 & 2,25 & 1,71 \\
\hline $\begin{array}{l}\text { 24. Possuir planos de emergência ambiental, que relacionem todos os seus } \\
\text { processos e produtos ou serviços que envolvam situações de risco, e treinar } \\
\text { seus empregados regularmente para enfrentar tais situações (Ethos, 2013). }\end{array}$ & 0,75 & 2,25 & 2,25 & 2,25 & 2,25 & 2,25 & 2,25 & 0,75 & 0,75 & 0,75 & 0,75 & 9 & 0,75 & 0,75 & 0,75 & 0,75 & 0,75 & 2,25 & 1,79 \\
\hline 25.Identificar e monitorar os riscos e os aspectos ambientais (Ethos, 2013). & 0,75 & 2,25 & 9 & 6,75 & 2,25 & 2,25 & 2,25 & 0,75 & 0,75 & 0,75 & 0,75 & 0,75 & 5,25 & 5,25 & 0,75 & 0,75 & 0,75 & 2,25 & 2,46 \\
\hline 26. Elaborar planos de ações (Ethos, 2013). & 0 & 0 & 0 & 0 & 0 & 0 & 0 & 0 & 0 & 4,5 & 4,5 & 4,5 & 2,25 & 0 & 2,25 & 0,75 & 0,75 & 0,75 & 1,13 \\
\hline 27. Divulgar o inventário de emissões de GEE (ISE, 2013). & 0,75 & 0,75 & 3,75 & 4,5 & 0,75 & 0,75 & 0,75 & 5,25 & 0,75 & 0,75 & 0,75 & 0,75 & 3 & 0,75 & 0,75 & 0,75 & 0,75 & 0,75 & 1,50 \\
\hline $\begin{array}{l}\text { 28. Os processos de gestão da companhia devem incorporar o uso } \\
\text { sustentável dos recursos naturais renováveis como requisito prioritário (ISE, } \\
\text { 2013). }\end{array}$ & 0,75 & 4,5 & 6,75 & 2,25 & 1,5 & 1,5 & 0,75 & 0,75 & 0 & 0 & 2,25 & 0 & 0,75 & 0,75 & 0,75 & 0,75 & 0,75 & 2,25 & 1,50 \\
\hline MÉDIA - Requisitos da ISO 14001 & 1,04 & 3,46 & 4,50 & 4,10 & 2,48 & 2,31 & 2,08 & 1,50 & 1,44 & 1,79 & 1,44 & 1,90 & 2,31 & 2,02 & 1,10 & 0,92 & 0,92 & 1,73 & 2,06 \\
\hline
\end{tabular}


Apêndice 12. Matriz de Relação Consolidada ISO 14001 - Dimensão Econômica.

\begin{tabular}{|c|c|c|c|c|c|c|c|c|c|c|c|c|c|c|c|c|c|c|c|}
\hline \multirow[b]{2}{*}{$\begin{array}{l}\text { Requisitos da sustentabilidade } \\
\text { empresarial - Dimensão econômica }\end{array}$} & \multirow[b]{2}{*}{ 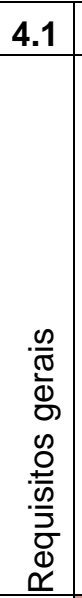 } & \multirow[b]{2}{*}{ 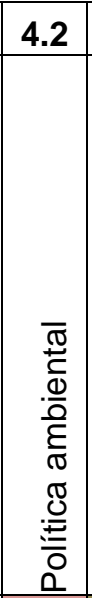 } & \multicolumn{3}{|c|}{4.3} & \multicolumn{7}{|c|}{4.4} & \multicolumn{6}{|c|}{4.5} & \multirow[b]{2}{*}{ 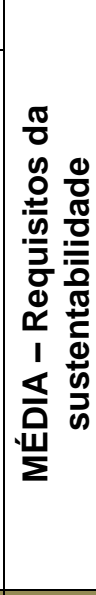 } \\
\hline & & & 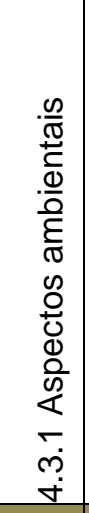 & 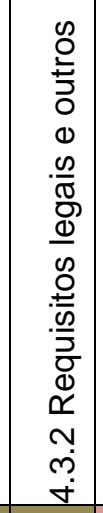 & 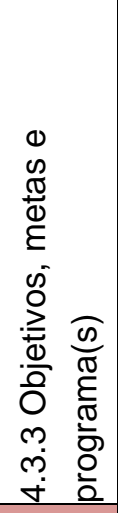 & 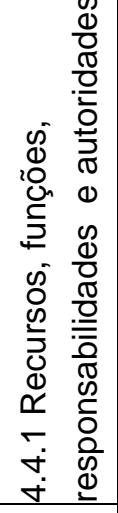 & 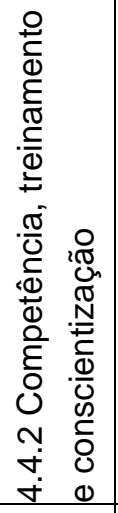 & 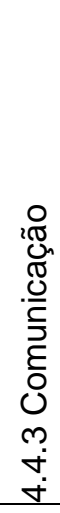 & 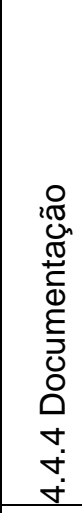 & 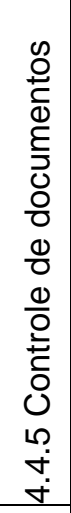 & 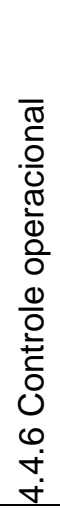 & 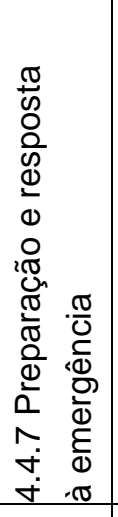 & 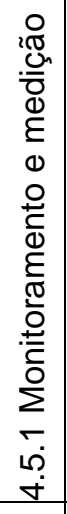 & 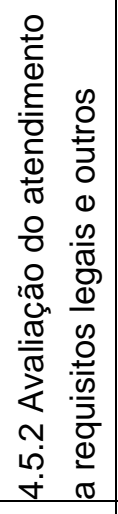 & 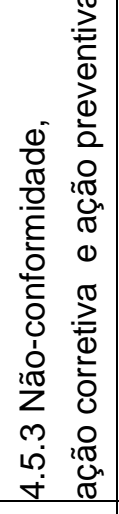 & 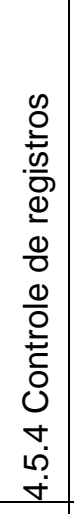 & 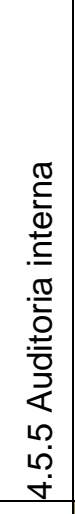 & 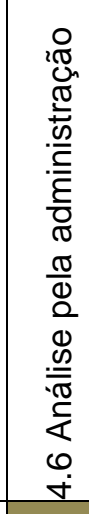 & \\
\hline $\begin{array}{l}\text { 29. Adotar políticas para os ativos intangíveis (capital organizacional, capital } \\
\text { humano, capital de informação e capital reputacional) (ISE, 2013). }\end{array}$ & 0 & 2,25 & 0,75 & 0,75 & 2,25 & 0 & 0 & 0 & 0 & 0 & 0 & 0 & 0 & 0 & 0 & 0 & 0 & 0,75 & 0,38 \\
\hline $\begin{array}{l}\text { 30. Considerar os valores da defesa da concorrência em suas políticas } \\
\text { corporativas (ISE, 2013). }\end{array}$ & 0 & 1,5 & 0,75 & 0 & 1,5 & 0 & 0 & 0 & 0 & 0 & 0 & 0 & 0 & 0 & 0 & 0 & 0 & 0,75 & 0,25 \\
\hline $\begin{array}{l}\text { 31. Elaborar processos e procedimentos implementados de gestão de riscos } \\
\text { corporativos (risco estratégico, risco operacional, risco financeiro - mercado, } \\
\text { crédito e liquidez, risco reputacional e risco legal) que considerem aspectos de } \\
\text { curto, médio e longo prazo, acompanhados pelo Conselho de Administração (ISE, } \\
\text { 2013). }\end{array}$ & 0 & 1,5 & 0,75 & 0,75 & 0,75 & 3,75 & 0,75 & 0 & 0 & 0 & 0 & 0 & 0 & 0 & 0 & 0 & 0 & 0,75 & 0,50 \\
\hline $\begin{array}{l}\text { 32. Restringir o uso de instrumentos financeiros derivativos para fins exclusivos de } \\
\text { proteção (ISE, 2013). }\end{array}$ & 0 & 0 & 0 & 0 & 0 & 1,5 & 0 & 0 & 0 & 0 & 0 & 0 & 0 & 0 & 0 & 0 & 0 & 0 & 0,08 \\
\hline $\begin{array}{l}\text { 33. Implementar processos e procedimentos para monitorar impactos econômicos } \\
\text { indiretos das atividades da companhia (ISE, 2013). }\end{array}$ & 0 & 0 & 0 & 0 & 0 & 0,75 & 0 & 0 & 0 & 0 & 0 & 0 & 0 & 0 & 0 & 0 & 0 & 0 & 0,04 \\
\hline $\begin{array}{l}\text { 34. Elaborar processos e procedimentos implementados de gestão de ativos } \\
\text { intangíveis, além dos contabilizados (ISE, 2013). }\end{array}$ & 0 & 0 & 0 & 0 & 0 & 1,5 & 0 & 0 & 1,5 & 0 & 0 & 0 & 0 & 0 & 0 & 0 & 0 & 0 & 0,17 \\
\hline $\begin{array}{l}\text { 35. Possuir sistema de gestão de desempenho baseado em indicadores vinculados } \\
\text { ao planejamento estratégico (ISE, 2013). }\end{array}$ & 0 & 2,25 & 2,25 & 0 & 6,75 & 1,5 & 0 & 0 & 0 & 0 & 0 & 0 & 0 & 0 & 0 & 0 & 0 & 0,75 & 0,75 \\
\hline 36. Implantar medidas de defesa da concorrência (ISE, 2013). & 0 & 0 & 0 & 0 & 0 & 0,75 & 0 & 0 & 0 & 0 & 0 & 0 & 0 & 0 & 0 & 0 & 0 & 0 & 0,04 \\
\hline $\begin{array}{l}\text { 37. Preparar e publicar as demonstrações financeiras em moeda constante (ISE, } \\
\text { 2013) }\end{array}$ & 0 & 0 & 0 & 0 & 0 & 0,75 & 0 & 0 & 0 & 0 & 0 & 0 & 0 & 0 & 0 & 0 & 0 & 0 & 0,04 \\
\hline $\begin{array}{l}\text { 38. Calcular o lucro econômico ou outras medidas de geração de valor econômico } \\
\text { (ISE, 2013). }\end{array}$ & 0 & 0 & 0 & 0 & 0 & 0,75 & 0 & 0 & 0 & 0 & 0 & 0 & 0 & 0 & 0 & 0 & 0 & 0 & 0,04 \\
\hline $\begin{array}{l}\text { 39. Relatar o valor econômico direto (receitas) gerado e distribuído (custos } \\
\text { operacionais; salários e benefícios de empregados; pagamentos a provedores de } \\
\text { capital; pagamentos ao governo (por país); investimentos comunitários), com base } \\
\text { no regime de competência de exercícios (GRI). }\end{array}$ & 0 & 0 & 0 & 0 & 2,25 & 3,75 & 0 & 0 & 0 & 0 & 0 & 0 & 0 & 0 & 0 & 0 & 0 & 0 & 0,33 \\
\hline 40. Elaborar um plano de benefícios da organização (GRI). & 0 & 0 & 0 & 0 & 0 & 0 & 0 & 0 & 0 & 0 & 0 & 0 & 0 & 0 & 0 & 0 & 0 & 0 & 0,00 \\
\hline MÉDIA - Requisitos ISO 14001 & 0 & 0,63 & 0,38 & 0,13 & 1,13 & 1,13 & 0,06 & 0 & 0,13 & 0 & 0 & 0 & 0 & 0 & 0 & 0 & 0 & 0,25 & 0,22 \\
\hline
\end{tabular}


Apêndice 13. Matriz de Relação Consolidada ISO 14001 - Dimensão socioambiental.

\begin{tabular}{|c|c|c|c|c|c|c|c|c|c|c|c|c|c|c|c|c|c|c|c|}
\hline \multirow[b]{2}{*}{$\begin{array}{l}\text { Requisitos da sustentabilidade } \\
\text { empresarial - Dimensão socioambiental }\end{array}$} & \multirow[b]{2}{*}{ 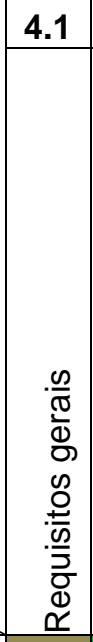 } & \multirow[b]{2}{*}{ 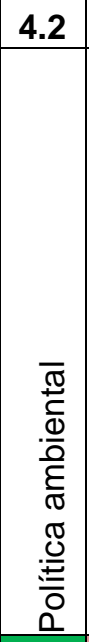 } & \multicolumn{3}{|c|}{4.3} & \multicolumn{7}{|c|}{4.4} & \multicolumn{6}{|c|}{4.5} & \multirow[b]{2}{*}{ 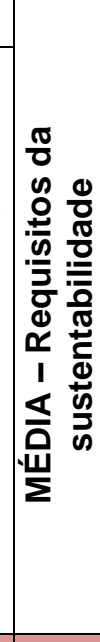 } \\
\hline & & & 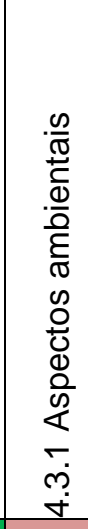 & 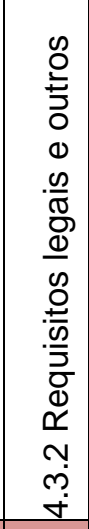 & 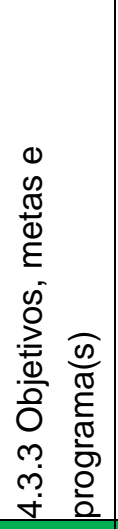 & 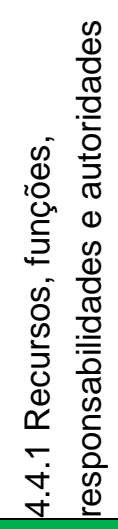 & 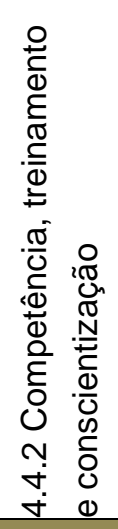 & 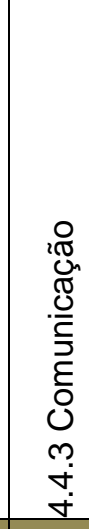 & 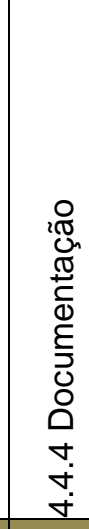 & $\begin{array}{l}0 \\
0 \\
0 \\
0 \\
0 \\
\frac{1}{5} \\
0 \\
0 \\
0 \\
0 \\
0 \\
0 \\
0 \\
0 \\
0 \\
0 \\
0 \\
0 \\
10 \\
\dot{0} \\
\dot{0}\end{array}$ & $\begin{array}{l}\overline{0} \\
\frac{0}{0} \\
\frac{0}{0} \\
\frac{\pi}{0} \\
\frac{0}{0} \\
0 \\
0 \\
0 \\
0 \\
0 \\
0 \\
0 \\
0 \\
0 \\
\dot{0} \\
\dot{v}\end{array}$ & 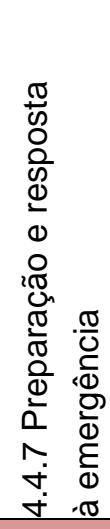 & 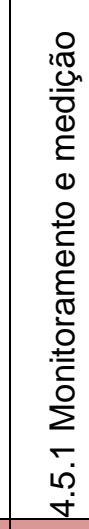 & 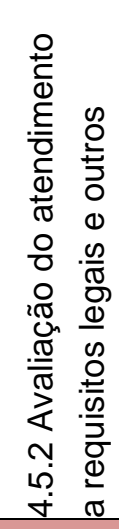 & 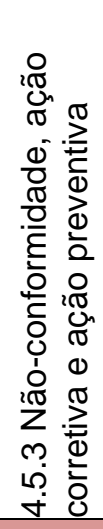 & 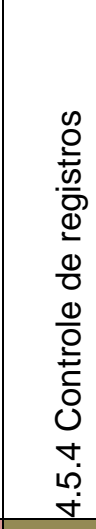 & 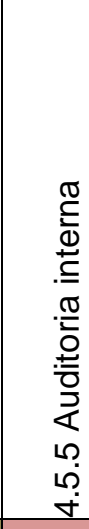 & 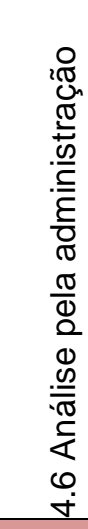 & \\
\hline $\begin{array}{l}\text { 41. Comprometimento da alta direção com as questões socioambientais } \\
\text { (Ethos, 2013). }\end{array}$ & 0,75 & 3,75 & 2,25 & 2,25 & 6,75 & 6,75 & 0,75 & 0,75 & 0,75 & 0,75 & 2,25 & 2,25 & 2,25 & 2,25 & 2,25 & 0,75 & 2,25 & 2,25 & 2,33 \\
\hline $\begin{array}{l}\text { 42. Incorporar critérios socioambiental na estratégia da organização (Ethos, } \\
\text { 2013). }\end{array}$ & 0,75 & 2,25 & 2,25 & 2,25 & 6,75 & 3,75 & 2,25 & 0,75 & 0,75 & 0,75 & 2,25 & 2,25 & 2,25 & 2,25 & 2,25 & 2,25 & 2,25 & 2,25 & 2,25 \\
\hline $\begin{array}{l}\text { 43. Comunicar a toda a organização e outras partes interessadas a } \\
\text { importância de considerar os aspectos socioambientais (Ethos, 2013). }\end{array}$ & 0,75 & 3 & 0,75 & 1,5 & 2,25 & 3,75 & 3,75 & 6,75 & 0,75 & 0,75 & 0,75 & 0,75 & 0,75 & 0,75 & 0,75 & 0,75 & 0,75 & 2,25 & 1,75 \\
\hline $\begin{array}{l}\text { 44. A responsabilidade socioambiental deve ser repassada em toda a cadeia } \\
\text { produtiva (Ethos, 2013), (ISE, 2013) e (GRI). }\end{array}$ & 0,75 & 3,75 & 0,75 & 0,75 & 5,25 & 5,25 & 5,25 & 2,25 & 0,75 & 0,75 & 0,75 & 0,75 & 0,75 & 0,75 & 0,75 & 0,75 & 0,75 & 2,25 & 1,83 \\
\hline $\begin{array}{l}\text { 45. Possuir normas de seleção e avaliação de fornecedores que contemplam } \\
\text { critérios específicos de responsabilidade socioambiental (Ethos, 2013), (ISE, } \\
\text { 2013) e (GRI). }\end{array}$ & 0,75 & 2,25 & 2,25 & 0,75 & 2,25 & 0,75 & 2,25 & 0,75 & 0,75 & 1,5 & 1,5 & 0,75 & 6,75 & 3 & 2,25 & 0,75 & 0,75 & 0,75 & 1,71 \\
\hline $\begin{array}{l}\text { 46. Produzir relatórios periódicos com evidências de que questões } \\
\text { relacionadas à responsabilidade socioambiental empresarial estão sendo } \\
\text { cumpridas e implementadas em sua cadeia produtiva (Ethos, 2013). }\end{array}$ & 0,75 & 3,75 & 0,75 & 0,75 & 2,25 & 2,25 & 3,75 & 1,5 & 0,75 & 0,75 & 0,75 & 0,75 & 0,75 & 0,75 & 0,75 & 0,75 & 0,75 & 2,25 & 1,38 \\
\hline $\begin{array}{l}\text { 47. Caso necessário treinar os fornecedores para que se adequem as } \\
\text { questões relacionadas a responsabilidade socioambiental (Ethos, 2013) e (ISE, } \\
\text { 2013). }\end{array}$ & 0,75 & 2,25 & 0,75 & 0,75 & 2,25 & 0,75 & 6,75 & 0,75 & 0,75 & 0,75 & 0,75 & 0,75 & 0,75 & 0,75 & 0,75 & 0,75 & 0,75 & 2,25 & 1,33 \\
\hline $\begin{array}{l}\text { 48. Participar de comitês/conselhos locais ou regionais para discutirem a } \\
\text { questão ambiental com o governo e a comunidade (Ethos, 2013). }\end{array}$ & 0,75 & 3 & 0,75 & 2,25 & 2,25 & 6,75 & 0,75 & 0,75 & 0,75 & 0,75 & 0,75 & 0,75 & 0,75 & 0,75 & 0,75 & 0,75 & 0,75 & 0,75 & 1,38 \\
\hline $\begin{array}{l}\text { 49. Desenvolver campanhas, apoiar ou participar de projetos educacionais em } \\
\text { parceria com organizações não governamentais e ambientalistas, exercendo } \\
\text { liderança social em favor dessa causa (Ethos, 2013). }\end{array}$ & 0,75 & 3 & 0,75 & 0 & 3,75 & 6,75 & 2,25 & 0,75 & 0 & 0 & 0 & 0 & 0 & 0 & 0 & 0 & 0 & 0,75 & 1,04 \\
\hline $\begin{array}{l}\text { 50. Disponibilizar suporte técnico aos consumidores finais com vistas ao uso } \\
\text { sustentável de seus produtos ou serviços (ISE, 2013). }\end{array}$ & 0,75 & 2,25 & 0 & 0 & 0 & 0 & 2,25 & 0,75 & 0 & 0 & 4,5 & 0 & 0 & 0 & 0 & 0 & 0 & 0,75 & 0,63 \\
\hline $\begin{array}{l}\text { 51. Fornecer aos consumidores e clientes informações detalhadas sobre danos } \\
\text { socioambientais resultantes do uso e na destinação final de seus produtos } \\
\text { (Ethos, 2013). }\end{array}$ & 0,75 & 0,75 & 0 & 0 & 0,75 & 0,75 & 0,75 & 2,25 & 0 & 0 & 4,5 & 0 & 0 & 0 & 0 & 1,5 & 4,5 & 0 & 0,92 \\
\hline $\begin{array}{l}\text { 52. Divulgar informações a respeito dos aspectos e impactos ambientais } \\
\text { gerados pela organização (ISE, 2013). }\end{array}$ & 0,75 & 5,25 & | 6,75 & 6,75 & 2,25 & 2,25 & 3,75 & 6,75 & 0,75 & 0,75 & 0,75 & 0,75 & 0,75 & 0,75 & 0,75 & 0,75 & 0,75 & 2,25 & 2,42 \\
\hline $\begin{array}{l}\text { 53. Mecanismos de Queixas e Reclamações Relativas a Impactos Ambientais } \\
\text { (ISE, 2013) }\end{array}$ & 0,75 & 0,75 & |5,25 & 6,75 & 3 & 3 & 0,75 & 5,25 & 0,75 & 0,75 & 0,75 & 0,75 & 0,75 & 0,75 & 0,75 & 0,75 & 0,75 & 2,25 & 1,92 \\
\hline MÉDIA - Requisitos da ISO 14001 & 0,75 & 2,77 & 1,79 & 1,90 & 3,06 & 3,29 & 2,71 & 2,31 & 0,58 & 0,63 & 1,56 & 0,81 & 1,27 & 0,98 & 0,92 & 0,81 & 1,15 & 1,62 & 1,6 \\
\hline
\end{tabular}


Apêndice 14. Matriz de Relação Consolidada ISO 14001 - Dimensão socioeconômica.

\begin{tabular}{|c|c|c|c|c|c|c|c|c|c|c|c|c|c|c|c|c|c|c|c|}
\hline \multirow[b]{2}{*}{$\begin{array}{l}\text { Requisitos da sustentabilidade } \\
\text { empresarial - Dimensão socioeconômica }\end{array}$} & \multirow[b]{2}{*}{ 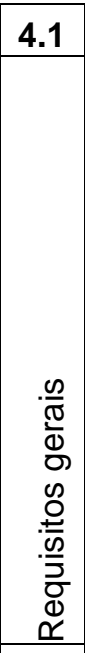 } & \multirow[b]{2}{*}{ 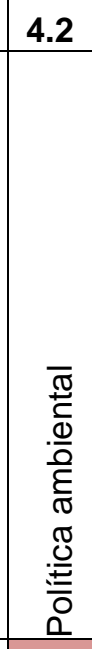 } & \multicolumn{3}{|c|}{4.3} & \multicolumn{7}{|c|}{4.4} & \multicolumn{6}{|c|}{4.5} & \multirow[b]{2}{*}{ 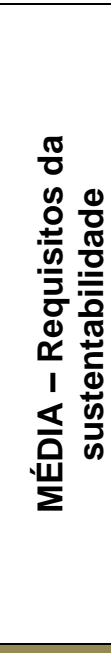 } \\
\hline & & & 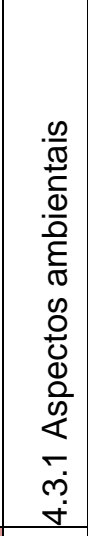 & 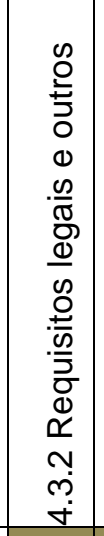 & 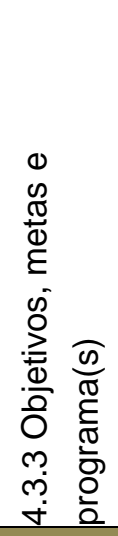 & 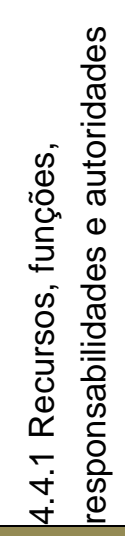 & 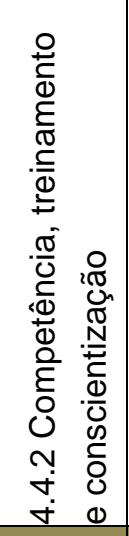 & 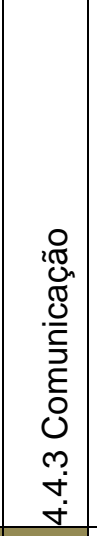 & 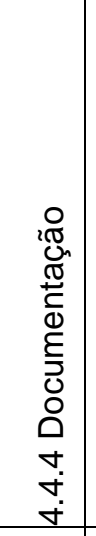 & 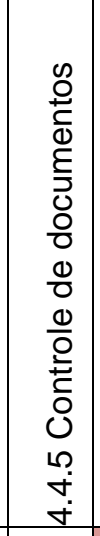 & $\begin{array}{l}\overline{0} \\
\frac{0}{0} \\
\frac{0}{0} \\
\frac{\pi}{0} \\
\overline{0} \\
0 \\
0 \\
0 \\
0 \\
0 \\
0 \\
0 \\
0 \\
0 \\
0 \\
\dot{0} \\
\dot{0}\end{array}$ & 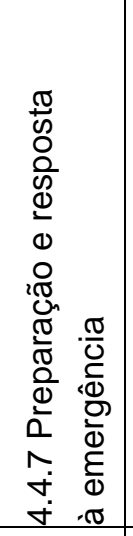 & 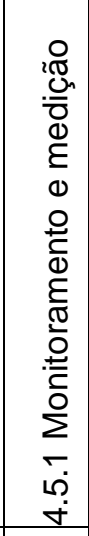 & 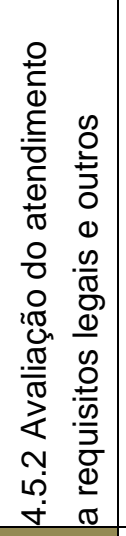 & 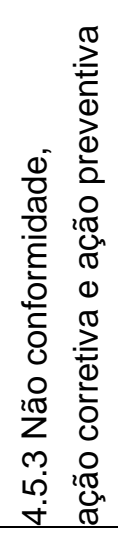 & 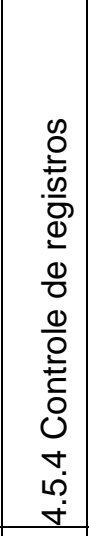 & 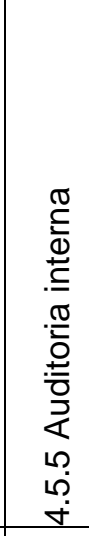 & 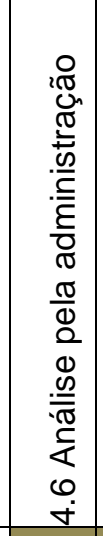 & \\
\hline $\begin{array}{l}\text { 54. Elaborar políticas que garanta a saúde e segurança dos colaboradores e } \\
\text { outras partes interessadas (Ethos, 2013) e (ISE, 2013). }\end{array}$ & 0 & 2,25 & 0 & 1,5 & 0,75 & 0,75 & 0,75 & 0,75 & 0 & 0 & 3 & 0 & 0 & 1,5 & 0 & 0 & 0 & 0,75 & 0,67 \\
\hline $\begin{array}{l}\text { 55. Elaborar políticas trabalhistas, remuneração, benefícios e carreira (Ethos, } \\
\text { 2013), (ISE, 2013) e (GRI, 211). }\end{array}$ & 3 & 0 & 0 & 0,75 & 1,5 & 0,75 & 0,75 & 0 & 0 & 0 & 0 & 0 & 0 & 0,75 & 0 & 0 & 0 & 0 & 0,42 \\
\hline $\begin{array}{l}\text { 56. Elaborar política(s) que aborde (m) as questões relacionadas aos clientes } \\
\text { (Ethos, 2013), (ISE, 2013) e (GRI). }\end{array}$ & 0 & 1,5 & 0,75 & 0 & 0 & 0,75 & 1,5 & 4,5 & 0 & 0 & 0 & 0 & 0 & 0 & 0 & 0 & 0 & 0 & 0,50 \\
\hline $\begin{array}{l}\text { 57. Oferecer condições de trabalho ideal para os colaboradores, } \\
\text { terceirizados e outras partes interessadas (treinamentos, infraestrutura, } \\
\text { incentivos, desenvolvimento profissional, entre outros) (Ethos, 2013) e (ISE, } \\
\text { 2013). }\end{array}$ & 0 & 1,5 & 0,75 & 5,25 & 0,75 & 0,75 & 2,25 & 0 & 0 & 0 & 0,75 & 0 & 0 & 0,75 & 0 & 0 & 0 & 0 & 0,71 \\
\hline $\begin{array}{l}\text { 58. Manter um canal de diálogo com os clientes, funcionários, fornecedores e } \\
\text { distribuidores (Ethos, 2013), (ISE, 2013) e (GRI). }\end{array}$ & 0 & 0,75 & 0,75 & 0,75 & 0,75 & 0,75 & 0,75 & 4,5 & 0 & 0 & 0,75 & 0 & 0 & 0,75 & 0 & 0 & 0 & 0 & 0,58 \\
\hline $\begin{array}{l}\text { 59. Incluir entre seus fornecedores indivíduos ou grupos da comunidade, tais } \\
\text { como cooperativas de pequenos produtores ou de iniciativas solidárias, } \\
\text { associações de bairro e organizações com projetos de geração de renda } \\
\text { para grupos usualmente excluídos (populações indígenas, pessoas com } \\
\text { deficiência etc.) (Ethos, 2013) (ISE, 2013) e (GRI). }\end{array}$ & 0 & 0,75 & 0 & 0 & 5,25 & 2,25 & 0 & 0 & 0 & 0 & 0 & 0 & 0 & 0 & 0 & 0 & 0 & 0 & 0,46 \\
\hline $\begin{array}{l}\text { 60. Elaborar programa de mapeamento para identificação de competências } \\
\text { potenciais a serem desenvolvidas (Ethos, 2013). }\end{array}$ & 0 & 0 & 0 & 0 & 2,25 & 1,5 & 0,75 & 0 & 0 & 0 & 0 & 0 & 0 & 0 & 0 & 0 & 0 & 0 & 0,25 \\
\hline $\begin{array}{l}\text { 61. Identificar empregados com alta incidência ou alto risco de doenças } \\
\text { relacionadas à sua ocupação (GRI) }\end{array}$ & 3 & 0,75 & 0 & 0,75 & 0,75 & 0 & 0,75 & 0 & 0 & 0 & 0 & 0 & 0 & 0 & 0 & 0 & 0 & 0 & 0,33 \\
\hline $\begin{array}{l}\text { 62. Adotar política contínua de esclarecimento aos funcionários sobre defesa } \\
\text { da concorrência (ISE, 2013). }\end{array}$ & 0 & 0 & 0 & 0 & 1,5 & 0 & 1,5 & 0,75 & 0 & 0 & 0 & 0 & 0 & 0 & 0 & 0 & 0 & 0 & 0,21 \\
\hline $\begin{array}{l}\text { 63. Manter os valores dos salários dos colaboradores sem distinção de } \\
\text { gênero (GRI). }\end{array}$ & 0 & 1,5 & 0 & 0 & 1,5 & 0 & 0 & 0 & 0 & 0 & 0 & 0 & 0 & 0 & 0 & 0 & 0 & 0 & 0,17 \\
\hline
\end{tabular}


Apêndice 15. Matriz de Relação Consolidada ISO 14001 - Dimensão Econômico-ambiental.

\begin{tabular}{|c|c|c|c|c|c|c|c|c|c|c|c|c|c|c|c|c|c|c|c|}
\hline \multirow[b]{2}{*}{$\begin{array}{l}\text { Requisitos da sustentabilidade } \\
\text { empresarial - Dimensão econômico-ambiental }\end{array}$} & \multirow[b]{2}{*}{ 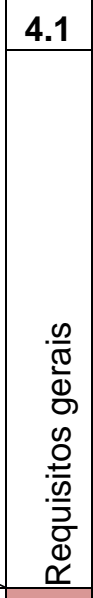 } & \multirow[b]{2}{*}{ 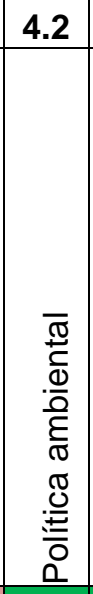 } & \multicolumn{3}{|c|}{4.3} & \multicolumn{7}{|c|}{4.4} & \multicolumn{6}{|c|}{4.5} & \multirow[b]{2}{*}{ 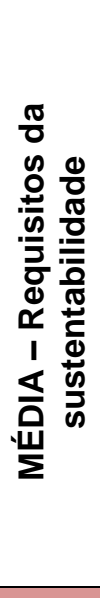 } \\
\hline & & & 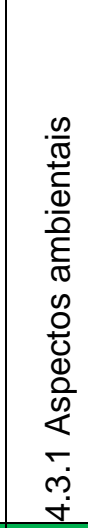 & 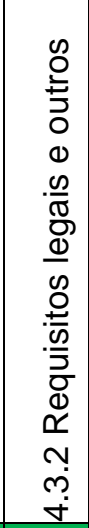 & 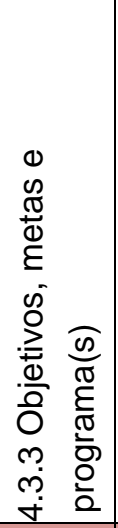 & 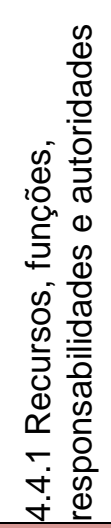 & 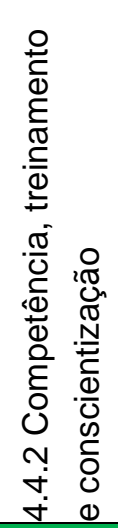 & 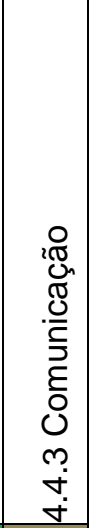 & 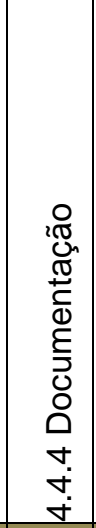 & 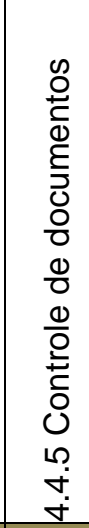 & 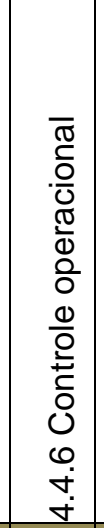 & 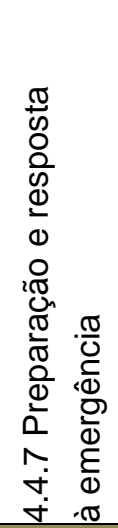 & 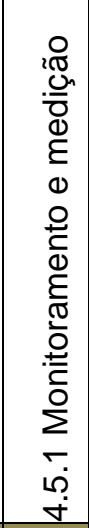 & 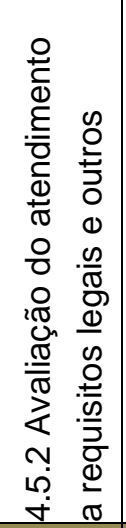 & 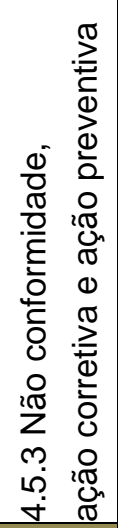 & 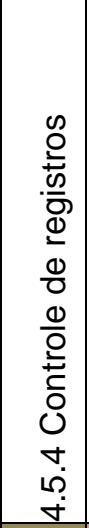 & 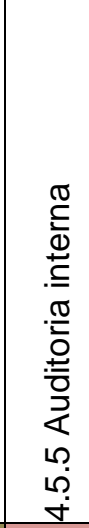 & 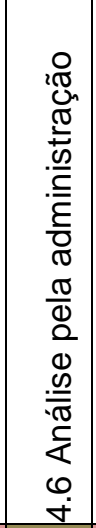 & \\
\hline $\begin{array}{l}\text { 64. Desenvolver programas internos de melhoramento ambiental (Ethos, } \\
\text { 2013). }\end{array}$ & 3 & 4,5 & 5,25 & 3,75 & 3 & 3 & 4,5 & 1,5 & 0,75 & 0,75 & 0,75 & 0,75 & 1,5 & 0,75 & 0,75 & 0,75 & 3 & 0,75 & 2,17 \\
\hline 65. Possuir programas de gerenciamento de resíduos (Ethos, 2013). & 3 & 0,75 & 6,75 & 6,75 & 2,25 & 2,25 & 2,25 & 2,25 & 2,25 & 6,75 & 2,25 & 6,75 & 2,25 & 2,25 & 0,75 & 2,25 & 2,25 & 2,25 & 3,13 \\
\hline $\begin{array}{l}\text { 66. Possuir programas específicos para verificar a origem e a cadeia de } \\
\text { produção dos insumos madeireiros e florestais utilizados em sua operação } \\
\text { diária e/ou processo produtivo (Ethos, 2013). }\end{array}$ & 0,75 & 2,25 & 6,75 & 6,75 & 2,25 & 0,75 & 2,25 & 0,75 & 2,25 & 5,25 & 0,75 & 0,75 & 0,75 & 0,75 & 0,75 & 0,75 & 0,75 & 2,25 & 2,08 \\
\hline 67. Priorizar políticas preventivas (Ethos, 2013). & 0,75 & 3 & 2,25 & 0,75 & 6,75 & 2,25 & 2,25 & 2,25 & 0,75 & 0,75 & 2,25 & 2,25 & 3 & 2,25 & 2,25 & 0,75 & 2,25 & 2,25 & 2,17 \\
\hline $\begin{array}{l}\text { 68. Possuir políticas e sistema de monitoramento visando o aumento da } \\
\text { qualidade ambiental (Ethos, 2013). }\end{array}$ & 2,25 & 2,25 & 2,25 & 0,75 & 6,75 & 4,5 & 2,25 & 2,25 & 0,75 & 0,75 & 2,25 & 2,25 & 6,75 & 2,25 & 2,25 & 3,75 & 2,25 & 2,25 & 2,71 \\
\hline $\begin{array}{l}\text { 69. Participar da destinação final dos produtos e processos pós-consumo } \\
\text { (Ethos, 2013). }\end{array}$ & 3 & 2,25 & 6,75 & 6,75 & 2,25 & 2,25 & 2,25 & 2,25 & 0,75 & 0,75 & 0,75 & 0,75 & 0,75 & 0,75 & 0,75 & 0,75 & 0,75 & 0,75 & 1,96 \\
\hline $\begin{array}{l}\text { 70. Sem alterar seus padrões tecnológicos atuais, procurar reduzir o consumo } \\
\text { de energia, de água, de produtos tóxicos e de matérias-primas e implantar } \\
\text { processos para a destinação adequada de resíduos (Ethos, 2013). }\end{array}$ & 0,75 & 6,75 & 6,75 & 6,75 & 2,25 & 2,25 & 2,25 & 2,25 & 0,75 & 0,75 & 6,75 & 2,25 & 2,25 & 2,25 & 2,25 & 2,25 & 2,25 & 2,25 & 3,00 \\
\hline 71. Considerar os passivos ambientais (ISE, 2013). & 0,75 & 4,5 & 6,75 & 9 & 2,25 & 2,25 & 0,75 & 0,75 & 0,75 & 0,75 & 0,75 & 0,75 & 0,75 & 0,75 & 0,75 & 0,75 & 0,75 & 2,25 & 2,00 \\
\hline $\begin{array}{l}\text { 72. Possuir seguro para degradação ambiental decorrente de acidentes em } \\
\text { suas operações (ISE, 2013). }\end{array}$ & 0 & 2,25 & 2,25 & 0 & 2,25 & 6,75 & 0 & 0 & 0 & 0 & 0 & 2,25 & 0 & 0 & 0 & 0 & 0 & 0,75 & 0,92 \\
\hline $\begin{array}{l}\text { 73. Considera a abordagem baseado no ciclo de vida dos produtos (ISE, } \\
\text { 2013). }\end{array}$ & 0 & 2,25 & 2,25 & 2,25 & 2,25 & 2,25 & 0 & 0 & 0 & 0 & 3 & 0 & 0 & 0 & 0 & 0 & 0 & 2,25 & 0,92 \\
\hline $\begin{array}{l}\text { 74. Possuir processo para medir, monitorar e auditar periodicamente os } \\
\text { aspectos ambientais significativos relacionados ao consumo de recursos } \\
\text { naturais e à produção de resíduos e dejetos, estabelecendo periodicamente } \\
\text { novas metas (Ethos, 2013), (ISE, 2013). }\end{array}$ & 0,75 & 2,25 & 9 & 2,25 & 6,75 & 2,25 & 0,75 & 0,75 & 0,75 & 0,75 & 3,75 & 2,25 & 6,75 & 2,25 & 2,25 & 0,75 & 4,5 & 2,25 & 2,83 \\
\hline $\begin{array}{l}\text { 75. Monitorar o consumo de recursos naturais na cadeia produtiva (ISE, } \\
\text { 2013). }\end{array}$ & 0,75 & 2,25 & 9 & 0,75 & 2,25 & 2,25 & 2,25 & 2,25 & 0,75 & 0,75 & 6,75 & 2,25 & 6,75 & 2,25 & 2,25 & 0,75 & 4,5 & 2,25 & 2,83 \\
\hline $\begin{array}{l}\text { 76. Considerar iniciativas tais como "ecodesign" ou DfE (Desing for } \\
\text { Environment) (ISE, 2013). }\end{array}$ & 0,75 & 2,25 & 2,25 & 0,75 & 6,75 & 3,75 & 2,25 & 0,75 & 0,75 & 0,75 & 4,5 & 2,25 & 2,25 & 2,25 & 0,75 & 0,75 & 0,75 & 2,25 & 2,04 \\
\hline $\begin{array}{l}\text { 77. As estratégias envolvendo a definição de produtos e/ou serviços } \\
\text { oferecidos pela companhia e/ou por suas controladas ou os projetos de } \\
\text { Pesquisa e Desenvolvimento elaborados pelas mesmas preveem planos para } \\
\text { reposicionamento (refere-se à mudança no mix de produtos/serviços do } \\
\text { portfólio e/ou público-alvo) em função das potenciais mudanças nos padrões } \\
\text { de oferta e demanda de recursos naturais (ISE, 2013). }\end{array}$ & 0 & 0 & 0 & 0 & 3 & 0 & 0 & 0 & 0 & 0 & 2,25 & 0 & 0 & 0 & 0 & 0 & 0 & 0 & 0,29 \\
\hline MÉDIA - Requisitos da ISO 14001 & 1,18 & 2,68 & 4,88 & 3,38 & 3,64 & 2,63 & 1,71 & 1,29 & 0,80 & 1,34 & 2,63 & 1,82 & 2,41 & 1,34 & 1,13 & 1,02 & 1,71 & 1,77 & 2,07 \\
\hline
\end{tabular}


Apêndice 16. Matriz de Relação Consolidada ISO 14001 - Dimensão ambiental-social-econômica.

\begin{tabular}{|c|c|c|c|c|c|c|c|c|c|c|c|c|c|c|c|c|c|c|c|}
\hline \multirow[b]{2}{*}{$\begin{array}{l}\text { Requisitos da sustentabilidade } \\
\text { empresarial - Dimensões ambiental- } \\
\text { social-econômica }\end{array}$} & \multirow[b]{2}{*}{ 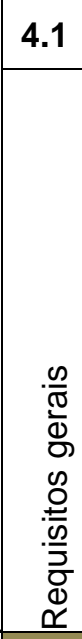 } & \multirow[b]{2}{*}{ 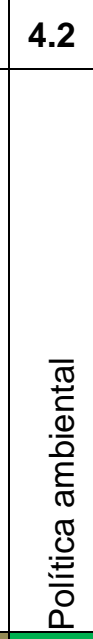 } & \multicolumn{3}{|c|}{4.3} & \multicolumn{7}{|c|}{4.4} & \multicolumn{6}{|c|}{4.5} & \multirow[b]{2}{*}{ 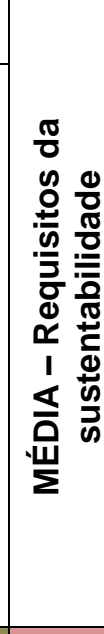 } \\
\hline & & & 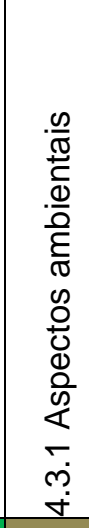 & 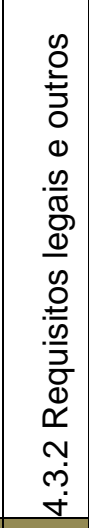 & 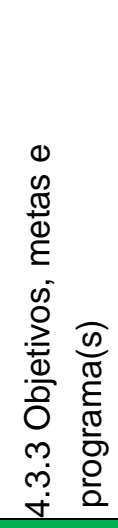 & 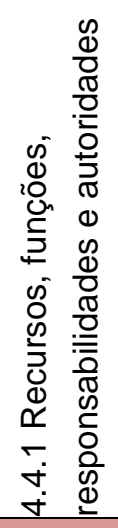 & 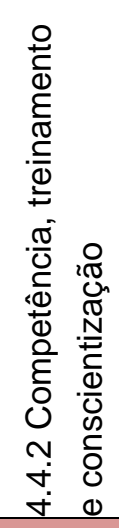 & 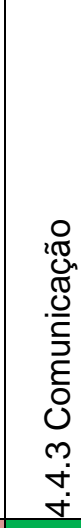 & 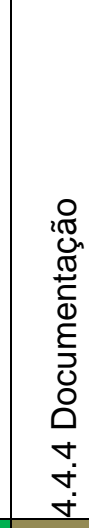 & 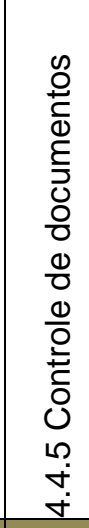 & 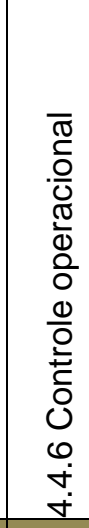 & 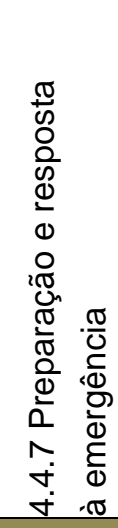 & 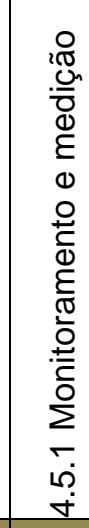 & 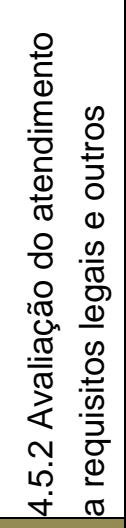 & 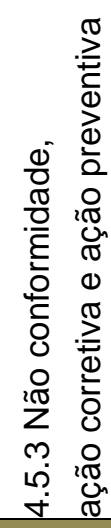 & 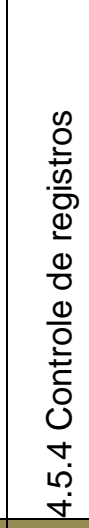 & 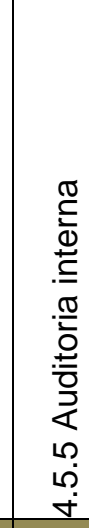 & 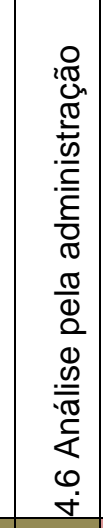 & \\
\hline 78. Elaborar política de comunicação (Ethos, 2013). & 0,75 & 4,5 & 0,75 & 0,75 & 6,75 & 2,25 & 2,25 & 5,25 & 0,75 & 0,75 & 0,75 & 0,75 & 0,75 & 0,75 & 0,75 & 0,75 & 0,75 & 0,75 & 1,71 \\
\hline 79. Assumir uma postura ética (Ethos, 2013). & 0,75 & 6,75 & 0,75 & 4,5 & 2,25 & 0,75 & 6,75 & 2,25 & 0,75 & 0,75 & 0,75 & 0,75 & 0,75 & 0,75 & 2,25 & 0,75 & 0,75 & 2,25 & 1,96 \\
\hline $\begin{array}{l}\text { 80. Identificar as partes interessadas e conhecer o contexto em que cada } \\
\text { parte está inserida para que as mesmas possam auxiliar na mitigação dos } \\
\text { impactos socioambientais envolvidos em cada contexto (Ethos, 2013) e } \\
\text { (ISE, 2013). }\end{array}$ & 0,75 & 6 & 2,25 & 2,25 & 6,75 & 5,25 & 5,25 & 0,75 & 0,75 & 0,75 & 2,25 & 0,75 & 0,75 & 0,75 & 0,75 & 0,75 & 0,75 & 2,25 & 2,21 \\
\hline $\begin{array}{l}\text { 81. Manter o diálogo com as partes interessadas (Ethos, 2013) (ISE, 2013) } \\
\text { e (GRI). }\end{array}$ & 0,75 & 2,25 & 0,75 & 2,25 & 2,25 & 2,25 & 1,5 & 5,25 & 0,75 & 0,75 & 0,75 & 0,75 & 0,75 & 0,75 & 0,75 & 0,75 & 0,75 & 2,25 & 1,46 \\
\hline $\begin{array}{l}\text { 82. Monitorar os impactos causados por suas atividades na comunidade de } \\
\text { entorno (Ethos, 2013). }\end{array}$ & 0,75 & 0,75 & 6,75 & 5,25 & 2,25 & 0,75 & 0,75 & 0,75 & 0,75 & 0,75 & 0,75 & 0,75 & 6,75 & 0,75 & 2,25 & 0,75 & 0,75 & 2,25 & 1,92 \\
\hline $\begin{array}{l}\text { 83. Possuir conselho ou responsável formal por questões éticas internas e } \\
\text { externas e garantir a gerência eficaz (Ethos, 2013) e (ISE, 2013). }\end{array}$ & 2,25 & 0,75 & 2,25 & 0,75 & 2,25 & 6,75 & 5,25 & 0,75 & 0,75 & 0,75 & 0,75 & 0,75 & 0,75 & 0,75 & 0,75 & 0,75 & 0,75 & 2,25 & 1,67 \\
\hline 84. Não praticar concorrência desleal (Ethos, 2013) e (GRI). & 0 & 0 & 0 & 4,5 & 4,5 & 0 & 0 & 0 & 0 & 0 & 0 & 0 & 0 & 0 & 0 & 0 & 0 & 0 & 0,50 \\
\hline $\begin{array}{l}\text { 85. Cumprir a legislação e pagamentos de tributos (Ethos, 2013) e (ISE, } \\
\text { 2013). }\end{array}$ & 0,75 & 2,25 & 0,75 & 6,75 & 0,75 & 0,75 & 0,75 & 0,75 & 0,75 & 0,75 & 0,75 & 0,75 & 0,75 & 0,75 & 0,75 & 0,75 & 0,75 & 0,75 & 1,17 \\
\hline $\begin{array}{l}\text { 86. Comunicar o compromisso com o desenvolvimento sustentável (ISE, } \\
\text { 2013). }\end{array}$ & 0,75 & 6,75 & 0,75 & 4,5 & 2,25 & 0,75 & 0,75 & 5,25 & 0,75 & 0,75 & 0,75 & 0,75 & 0,75 & 0,75 & 0,75 & 0,75 & 0,75 & 2,25 & 1,71 \\
\hline 87. Definir responsabilidades e autoridades (ISE, 2013). & 0,75 & 2,25 & 0,75 & 2,25 & 2,25 & 6,75 & 0,75 & 0,75 & 0,75 & 0,75 & 0,75 & 0,75 & 0,75 & 0,75 & 0,75 & 0,75 & 0,75 & 3,75 & 1,50 \\
\hline $\begin{array}{l}\text { 88. Existir processos e procedimentos implementados para gestão de } \\
\text { oportunidades corporativas que considere aspectos socioambientais de } \\
\text { curto, médio e longo prazo (ISE, 2013). }\end{array}$ & 2,25 & 2,25 & 0,75 & 0,75 & 6,75 & 0,75 & 0,75 & 0,75 & 0,75 & 0,75 & 0,75 & 0,75 & 0,75 & 0,75 & 0,75 & 0,75 & 0,75 & 2,25 & 1,33 \\
\hline $\begin{array}{l}\text { 89. Possuir plano de contigência que considere desastres naturais, } \\
\text { impactos ambientais, impactos sociais, impactos em } \\
\text { infraestrutura/operacionais (incluindo TI) (ISE, 2013). }\end{array}$ & $|0,75|$ & 2,25 & 6,75 & 2,25 & 2,25 & 2,25 & 2,25 & 0,75 & 2,25 & 2,25 & 2,25 & 4,5 & 6,75 & 2,25 & 2,25 & 2,25 & 2,25 & 2,25 & 2,71 \\
\hline MÉDIA - Requisitos da ISO 14001 & 0,94 & 3,06 & 1,94 & 3,06 & 3,44 & 2,44 & 2,25 & 1,94 & 0,81 & 0,81 & 0,94 & 1,00 & 1,69 & 0,81 & 1,06 & 0,81 & 0,81 & 1,94 & 1,65 \\
\hline
\end{tabular}


Apêndice 17. Matriz de Relação Consolidada NBR 16001 - Dimensão Social.

\begin{tabular}{|c|c|c|c|c|c|c|c|c|c|c|c|c|c|c|c|c|c|c|c|c|c|c|c|c|}
\hline \multirow[b]{2}{*}{$\begin{array}{l}\text { Requisitos da sustentabilidade } \\
\text { empresarial - Dimensão social }\end{array}$} & \multirow[b]{2}{*}{ 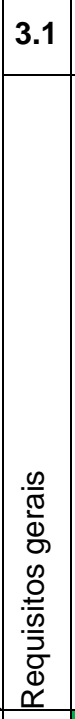 } & \multirow[b]{2}{*}{ 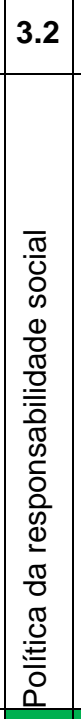 } & \multicolumn{7}{|c|}{3.3} & \multicolumn{5}{|c|}{3.4} & \multicolumn{4}{|c|}{3.5} & \multicolumn{5}{|c|}{3.6} & \multirow[b]{2}{*}{ 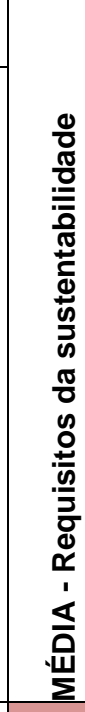 } \\
\hline & & & 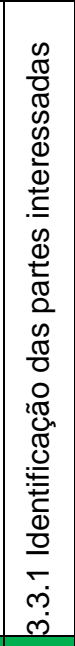 & 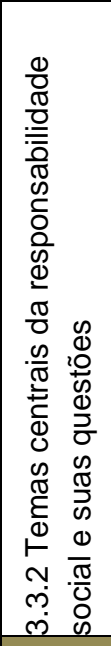 & 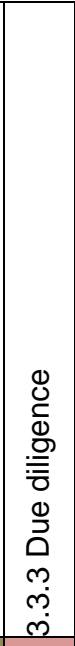 & 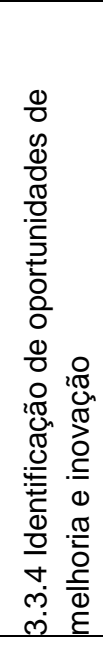 & 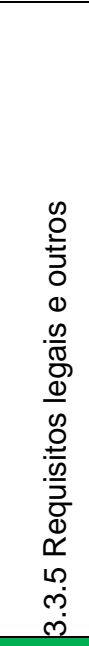 & 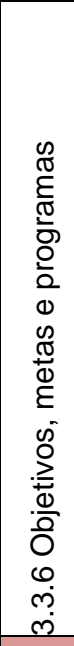 & 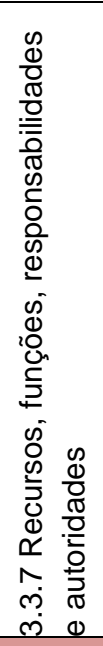 & 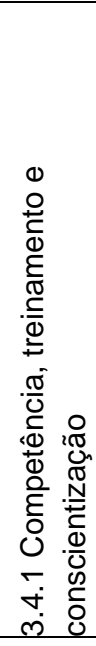 & 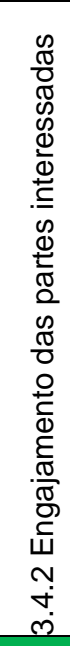 & 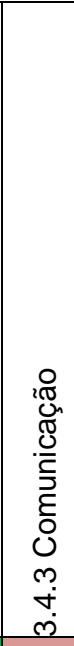 & 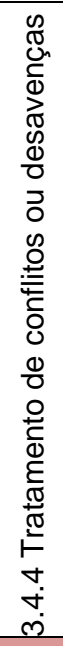 & 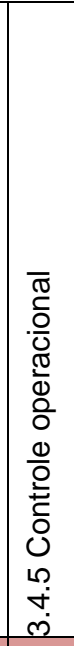 & 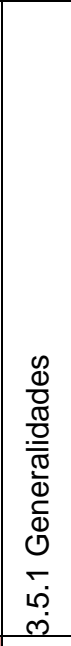 & 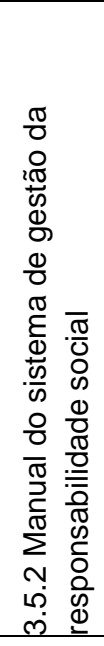 & 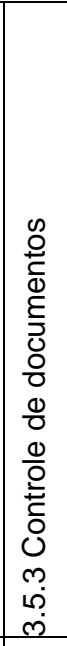 & 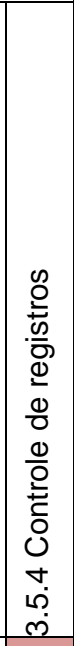 & 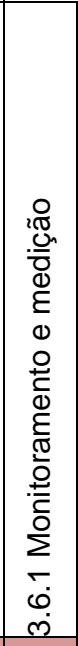 & 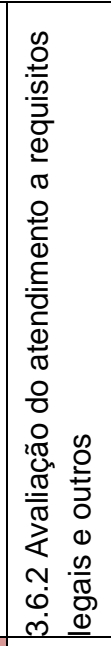 & 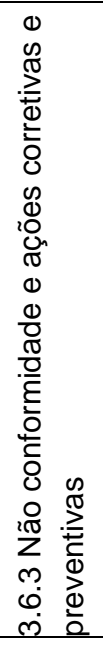 & 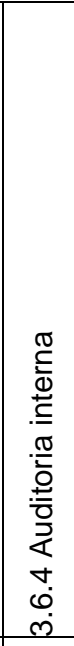 & 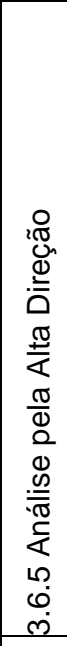 & \\
\hline $\begin{array}{l}\text { 1. Elaborar política para que os indicadores/dados/informações } \\
\text { advindos do processo de diálogo e engajamento das partes } \\
\text { interessadas sejam, preservadas (quando confidencial), } \\
\text { comparáveis, confiáveis, relevantes e compreensíveis por suas } \\
\text { partes interessadas (Ethos, 2013) e (ISE, 2013). }\end{array}$ & 0 & 9 & 9 & 1,5 & 3 & 0 & 9 & 3 & 3 & 0 & 9 & 3 & 3 & 3 & 0 & 0 & 0 & 3 & 3 & 0 & 0 & 0 & 0 & 2,67 \\
\hline $\begin{array}{l}\text { 2. Valorizar a diversidade, equidade e não discriminação ( racial, } \\
\text { gênero, opção sexual ou qualquer outra forma de discriminação) } \\
\text { (Ethos, 2013), (ISE, 2013) e (GRI). }\end{array}$ & 0 & 3 & 0 & 9 & 0 & 3 & 9 & 9 & 0 & 9 & 1,5 & 3 & 9 & 9 & 0 & 0 & 0 & 0 & 3 & 3 & 0 & 0 & 1,5 & 3,13 \\
\hline $\begin{array}{l}\text { 3.Considerar a responsabilidade social na cadeia de fornecimento } \\
\text { (Ethos, 2013) e (ISE, 2013). }\end{array}$ & 0 & 6 & 0 & 9 & 3 & 0 & 9 & 3 & 3 & 0 & 6 & 6 & 0 & 9 & 0 & 1,5 & 3 & 3 & 3 & 0 & 0 & 0 & 1,5 & 2,87 \\
\hline 4. Engajar as partes interessadas (Ethos, 2013) e (ISE, 2013). & 1,5 & 4,5 & 9 & 9 & 0 & 1,5 & 9 & 9 & 3 & 0 & 9 & 6 & 6 & 0 & 0 & 1,5 & 0 & 0 & 3 & 3 & 0 & 0 & 1,5 & 3,33 \\
\hline $\begin{array}{l}\text { 5. Participar do processo de elaboração, avaliação, implantação ou } \\
\text { monitoramento de políticas públicas (Ethos, 2013), (ISE, 2013) e } \\
\text { (GRI). }\end{array}$ & 0 & 1,5 & 3 & 3 & 0 & 3 & 9 & 6 & 4,5 & 1,5 & 1,5 & 3 & 1,5 & 0 & 0 & 0 & 0 & 0 & 0 & 3 & 0 & 0 & 0 & 1,76 \\
\hline $\begin{array}{l}\text { 6. Apoiar, patrocinar e desenvolver projetos, programas, } \\
\text { campanhas e pesquisas científicas (Ethos, 2013), (ISE, 2013) e } \\
\text { (GRI). }\end{array}$ & 0 & 0 & 0 & 3 & 0 & 3 & 0 & 0 & 0 & 3 & 0 & 0 & 0 & 0 & 0 & 0 & 0 & 0 & 0 & 0 & 0 & 0 & 0 & 0,39 \\
\hline $\begin{array}{l}\text { 7. Oferecer oportunidade de trabalho para grupos vulneráveis } \\
\text { (Ethos, 2013). }\end{array}$ & 0 & 0 & 0 & 9 & 0 & 0 & 9 & 9 & 3 & 9 & 0 & 3 & 0 & 3 & 0 & 0 & 0 & 0 & 3 & 0 & 0 & 0 & 0 & 2,09 \\
\hline $\begin{array}{l}\text { 8. Estimular os funcionários a cumprirem os valores e princípios } \\
\text { éticos da organização (Ethos, 2013). }\end{array}$ & 0 & 6 & 1,5 & 9 & 1,5 & 0 & 1,5 & 3 & 3 & 9 & 9 & 9 & 0 & 0 & 0 & 1,5 & 0 & 0 & 1,5 & 4,5 & 0 & 0 & 4,5 & 2,80 \\
\hline 9. Garantir o atendimento dos direitos humanos (GRI). & 0 & 6 & 1,5 & 9 & 0 & 0 & 4,5 & 9 & 3 & 9 & 1,5 & 9 & 9 & 9 & 0 & 0 & 0 & 0 & 3 & 0 & 0 & 0 & 4,5 & 3,39 \\
\hline $\begin{array}{l}\text { 10.Elaborar programas de aconselhamento sobre o planejamento } \\
\text { de carreiras, de forma a auxiliar os empregados na reflexão sobre } \\
\text { suas funções e identificação de objetivos em longo prazo (Ethos, } \\
\text { 2013). }\end{array}$ & 0 & 0 & 0 & 0 & 0 & 0 & 0 & 3 & 9 & 9 & 0 & 3 & 0 & 3 & 0 & 0 & 0 & 0 & 3 & 0 & 0 & 0 & 0 & 1,30 \\
\hline $\begin{array}{l}\text { 11.Elaborar programa sistemático de preparação interna, } \\
\text { oferecendo oportunidades de aproveitamento da capacidade de } \\
\text { trabalho dos aposentados (Ethos, 2013). }\end{array}$ & 0 & 0 & 0 & 3 & 0 & 0 & 0 & 9 & 6 & 3 & 4,5 & 3 & 0 & 3 & 0 & 0 & 0 & 0 & 0 & 0 & 0 & 0 & 0 & 1,37 \\
\hline $\begin{array}{l}\text { 12.Elaborar programa para empregar, na medida do possível, o } \\
\text { maior número de moradores do local em que está inserida, dando- } \\
\text { Ihes formação, com o objetivo de aumentar os níveis de } \\
\text { qualificação daquela comunidade, em cooperação com sindicatos, } \\
\text { ONGs, representantes da comunidade ou autoridades públicas } \\
\text { competentes (Ethos, 2013) e (ISE, 2013). }\end{array}$ & 0 & 1,5 & 9 & 9 & 0 & 1,5 & 1,5 & 3 & 4,5 & 9 & 4,5 & 6 & 0 & 0 & 0 & 1,5 & 0 & 0 & 3 & 4,5 & 0 & 1,5 & 1,5 & 2,67 \\
\hline $\begin{array}{l}\text { 13. Elaborar programa específico de contratação de pessoas com } \\
\text { deficiência (Ethos, 2013). }\end{array}$ & 0 & 0 & 3 & 9 & 0 & 1,5 & 4,5 & 6 & 4,5 & 9 & 4,5 & 6 & 0 & 0 & 0 & 0 & 0 & 0 & 3 & 0 & 0 & 1,5 & 1,5 & 2,35 \\
\hline $\begin{array}{l}\text { 14. Identificar os tipos e taxas de lesões, doenças ocupacionais, } \\
\text { dias perdidos, absenteísmo e número de óbitos relacionados ao } \\
\text { trabalho, discriminados por região e gênero (GRI). }\end{array}$ & 0 & 3 & 3 & 9 & 0 & 0 & 9 & 9 & 3 & 3 & 0 & 6 & 0 & 9 & 0 & 0 & 3 & 3 & 9 & 3 & 0 & 1,5 & 1,5 & 3,26 \\
\hline $\begin{array}{l}\text { 15. Estabelecer acordos formais entre as empresas, sindicatos e } \\
\text { colaboradores para manter o direito dos colaboradores (GRI). }\end{array}$ & 0 & 3 & 3 & 9 & 0 & 0 & 9 & 3 & 0 & 0 & 6 & 6 & 0 & 3 & 0 & 0 & 3 & 3 & 0 & 0 & 0 & 0 & 1,5 & 2,15 \\
\hline MÉDIA - Requisitos NBR 16001 & 0,1 & 2,9 & 2,8 & 6,7 & 0,5 & 0,9 & 5,6 & 5,6 & 3,3 & 4,9 & 3,8 & 4,8 & 1,9 & 3,4 & 0 & 0,4 & 0,6 & 0,8 & 2,5 & 1,4 & 0 & 0,3 & 1,3 & 2,37 \\
\hline
\end{tabular}


Apêndice 18. Matriz de Relação Consolidada NBR 16001 - Dimensão ambiental.

\begin{tabular}{|c|c|c|c|c|c|c|c|c|c|c|c|c|c|c|c|c|c|c|c|c|c|c|c|c|}
\hline & 3.1 & 3.2 & & & & 3.3 & & & & & & 3.4 & & & & 3. & & & & & 3.6 & & & \\
\hline $\begin{array}{l}\text { Requisitos da sustentabilidade } \\
\text { empresarial - Dimensão ambiental. }\end{array}$ & 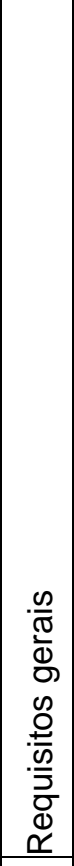 & 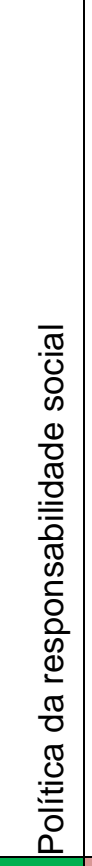 & 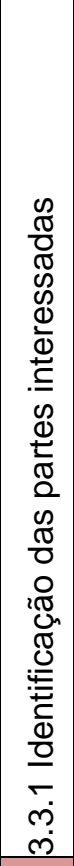 & 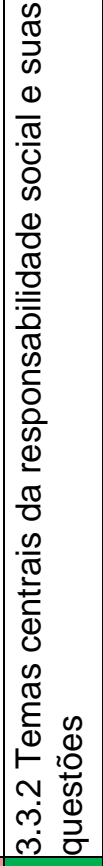 & 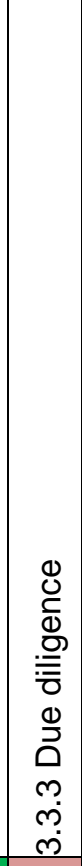 & 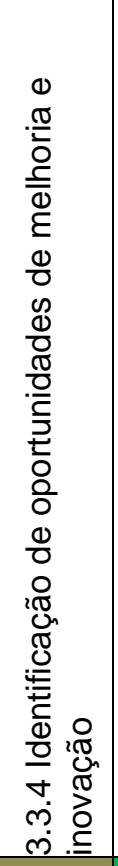 & 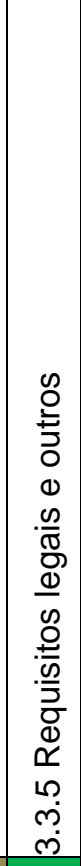 & 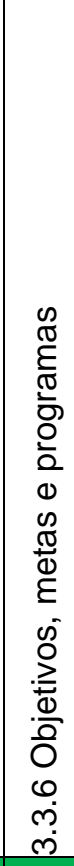 & 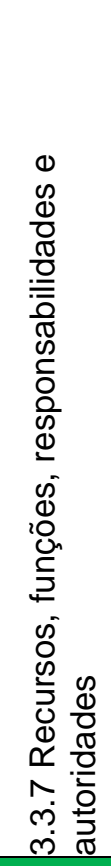 & 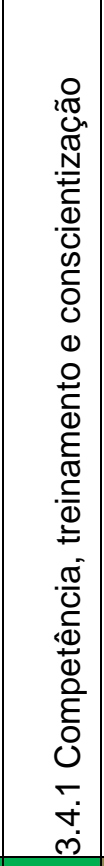 & 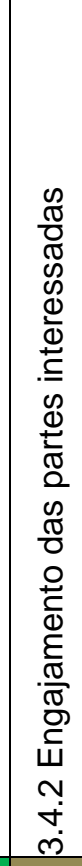 & 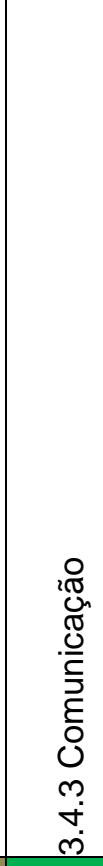 & 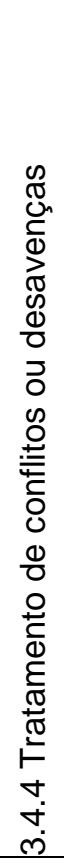 & 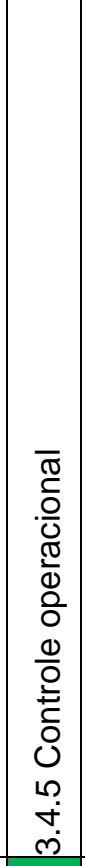 & 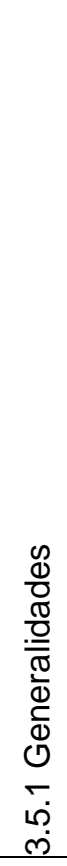 & 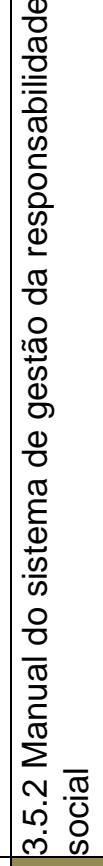 & 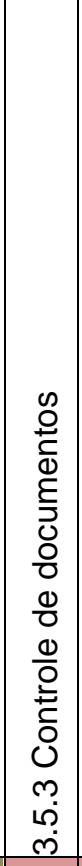 & 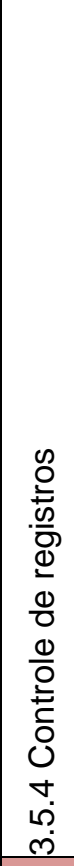 & 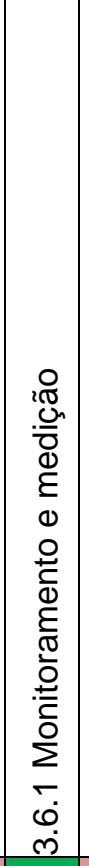 & 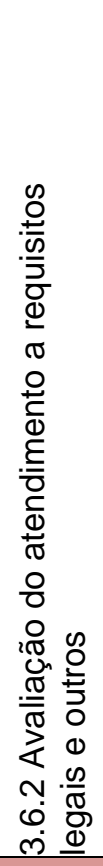 & 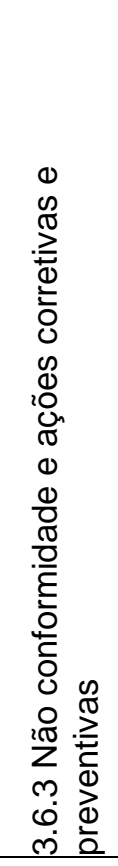 & 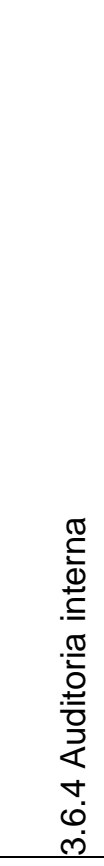 & 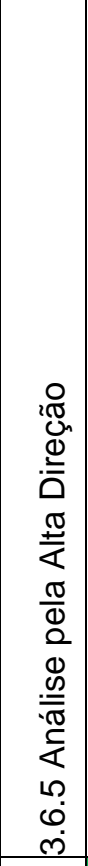 & 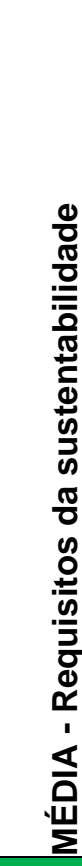 \\
\hline $\begin{array}{l}\text { 16. Garantir a preservação das Áreas de Preservação } \\
\text { Permanente (APP) (ISE, 2013). }\end{array}$ & 0 & 6 & 3 & 9 & 3 & 1,5 & 9 & 9 & 6 & 6 & 1,5 & 6 & 0 & 9 & 0 & 1,5 & 3 & 3 & 9 & 3 & 0 & 0 & 0 & 3,85 \\
\hline $\begin{array}{l}\text { 17. Delimitar a área de Reserva Legal em situações aplicáveis } \\
\text { (ISE, 2013). }\end{array}$ & 0 & 6 & 3 & 9 & 3 & 1,5 & 9 & 9 & 6 & 6 & 1,5 & 6 & 0 & 9 & 0 & 1,5 & 3 & 3 & 9 & 3 & 0 & 0 & 0 & 3,85 \\
\hline $\begin{array}{l}\text { 18. Possuir todas as licenças necessárias no licenciamento } \\
\text { ambiental (ISE, 2013). }\end{array}$ & 0 & 6 & 3 & 9 & 3 & 1,5 & 9 & 9 & 6 & 6 & 1,5 & 6 & 0 & 9 & 0 & 1,5 & 3 & 3 & 9 & 3 & 0 & 0 & 0 & 3,85 \\
\hline $\begin{array}{l}\text { 19. Considerar a questão das mudanças climáticas (ISE, } \\
\text { 2013). }\end{array}$ & 0 & 6 & 3 & 9 & 3 & 1,5 & 9 & 9 & 6 & 6 & 1,5 & 6 & 0 & 9 & 0 & 1,5 & 3 & 3 & 9 & 3 & 0 & 0 & 0 & 3,85 \\
\hline $\begin{array}{l}\text { 20. Elaborar Política Ambiental (deve ser formal, de } \\
\text { conhecimento de todos os empregados e constar no código } \\
\text { de conduta e/ou na declaração de valores das empresas) }\end{array}$ & 0 & 9 & 0 & 3 & 0 & 0 & 0 & 3 & 3 & 9 & 0 & 9 & 0 & 0 & 0 & 3 & 3 & 0 & 0 & 0 & 0 & 0 & 1,5 & 1,89 \\
\hline $\begin{array}{l}\text { 21. Contribuir para a preservação da biodiversidade por meio } \\
\text { de políticas específicas (Ethos, 2013) e (ISE, 2013). }\end{array}$ & 0 & 6 & 3 & 9 & 1,5 & 1,5 & 9 & 9 & 6 & 6 & 3 & 6 & 0 & 9 & 0 & 1,5 & 3 & 3 & 9 & 3 & 0 & 0 & 0 & 3,85 \\
\hline $\begin{array}{l}\text { 22. Possuir área ou comitê responsável pelo meio ambiente } \\
\text { (Ethos, 2013). }\end{array}$ & 0 & 1,5 & 0 & 3 & 0 & 0 & 3 & 3 & 9 & 3 & 0 & 3 & 0 & 3 & 0 & 3 & 3 & 0 & 0 & 0 & 0 & 0 & 1,5 & 1,57 \\
\hline $\begin{array}{l}\text { 23. Exigir estudos de impacto ambiental em toda a cadeia } \\
\text { produtiva (Ethos, 2013). }\end{array}$ & 0 & 6 & 1,5 & 9 & 3 & 1,5 & 9 & 6 & 6 & 4,5 & 3 & 6 & 0 & 9 & 0 & 1,5 & 3 & 3 & 6 & 1,5 & 0 & 0 & 0 & 3,46 \\
\hline $\begin{array}{l}\text { 24. Possuir planos de emergência ambiental, que relacionem } \\
\text { todos os seus processos e produtos ou serviços que } \\
\text { envolvam situações de risco, e treinar seus empregados } \\
\text { regularmente para enfrentar tais situações (Ethos, 2013). }\end{array}$ & 0 & 1,5 & 1,5 & 9 & 0 & 0 & 9 & 3 & 9 & 9 & 0 & 9 & 0 & 3 & 0 & 0 & 9 & 9 & 3 & 0 & 0 & 0 & 1,5 & 3,33 \\
\hline $\begin{array}{l}\text { 25. Identificar e monitorar os riscos e os aspectos ambientais } \\
\text { (Ethos, 2013). }\end{array}$ & 0 & 9 & 3 & 9 & 0 & 0 & 9 & 3 & 3 & 3 & 0 & 3 & 0 & 9 & 0 & 0 & 3 & 3 & 9 & 3 & 0 & 3 & 1,5 & 3,20 \\
\hline 26. Elaborar planos de ações (Ethos, 2013). & 0 & 1,5 & 0 & 0 & 0 & 0 & 0 & 0 & 3 & 3 & 0 & 0 & 0 & 3 & 0 & 3 & 3 & 3 & 3 & 0 & 6 & 3 & 1,5 & 1,43 \\
\hline 27. Divulgar o inventário de emissões de GEE (ISE, 2013). & 0 & 1,5 & 3 & 1,5 & 0 & 1,5 & 9 & 3 & 3 & 3 & 0 & 9 & 0 & 0 & 0 & 3 & 3 & 3 & 9 & 3 & 0 & 0 & 1,5 & 2,48 \\
\hline $\begin{array}{l}\text { 28. Os processos de gestão da companhia devem incorporar } \\
\text { o uso sustentável dos recursos naturais renováveis como } \\
\text { requisito prioritário (ISE, 2013). }\end{array}$ & 0 & 9 & 0 & 9 & 0 & 1,5 & 1,5 & 9 & 3 & 0 & 0 & 1,5 & 0 & 9 & 0 & 3 & 3 & 3 & 9 & 3 & 0 & 0 & 1,5 & 2,87 \\
\hline MÉDIA - Requisitos NBR 16001 & 0 & 5,3 & 1,8 & 6,81 & 1,2 & 0,92 & 6,6 & 5,8 & 5,31 & 4,96 & 0,9 & 5,42 & 0 & 6,2 & 0 & 1,85 & 3,5 & 3 & 6,5 & 1,96 & 0,46 & 0,46 & 0,8 & 3,04 \\
\hline
\end{tabular}


Apêndice 19. Matriz de Relação Consolidada NBR 16001 - Dimensão econômica.

\begin{tabular}{|c|c|c|c|c|c|c|c|c|c|c|c|c|c|c|c|c|c|c|c|c|c|c|c|c|}
\hline & 3.1 & 3.2 & 3.3 & & & & & & & 3.4 & & & & & 3.5 & & & & 3.6 & & & & & \\
\hline $\begin{array}{l}\text { Requisitos da sustentabilidade } \\
\text { empresarial - Dimensão econômica. }\end{array}$ & 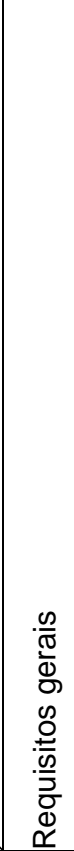 & 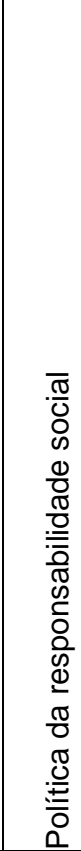 & 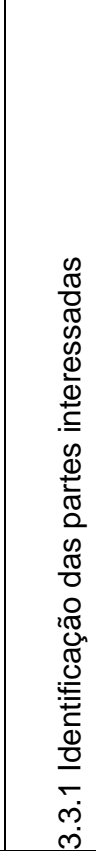 & 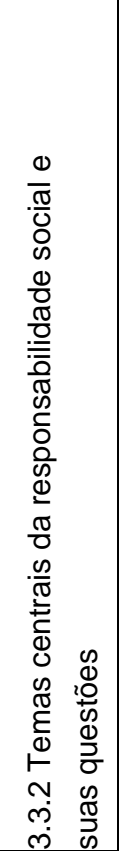 & 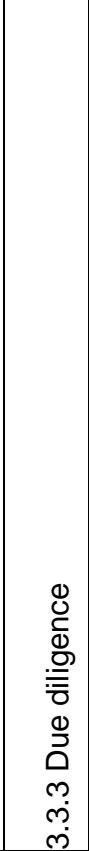 & 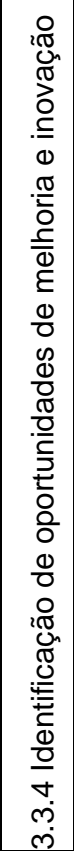 & 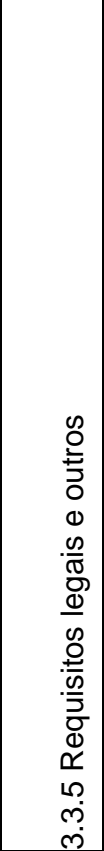 & 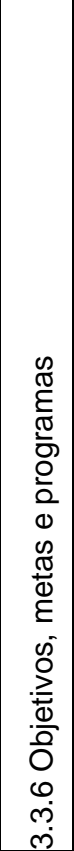 & 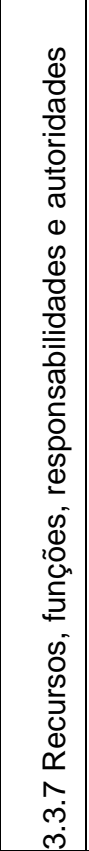 & 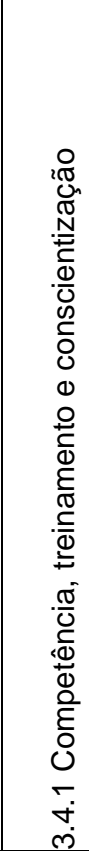 & 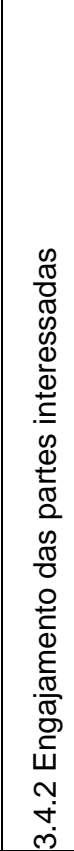 & 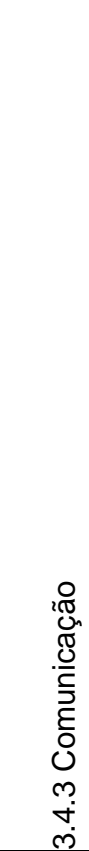 & 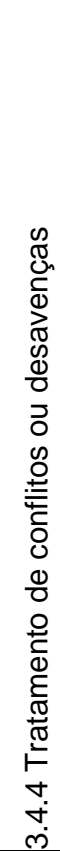 & 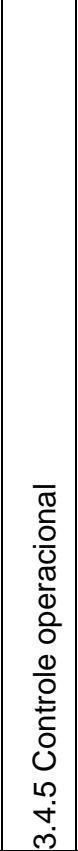 & 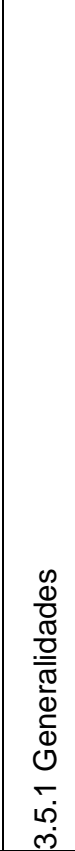 & 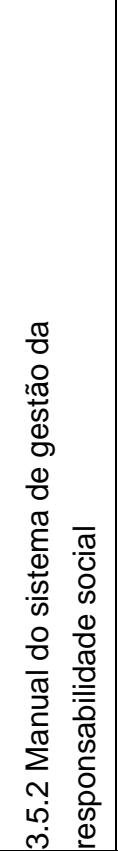 & 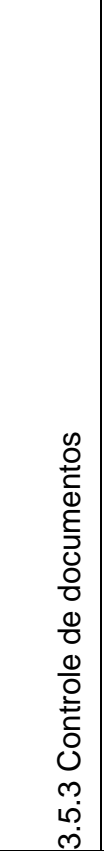 & 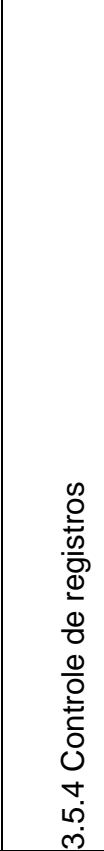 & 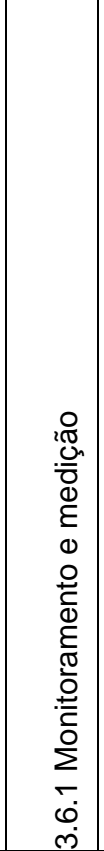 & 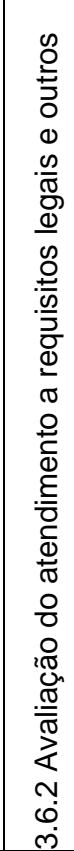 & 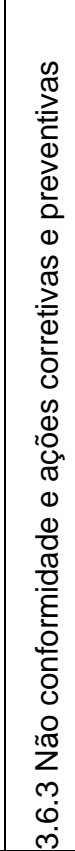 & 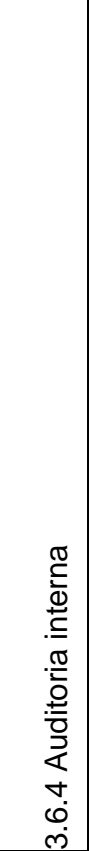 & 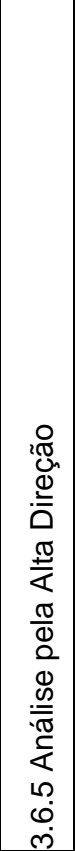 & 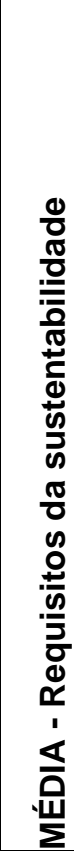 \\
\hline $\begin{array}{l}\text { 29. Adotar políticas para os ativos intangíveis (capital } \\
\text { organizacional, capital humano, capital de informação e capital } \\
\text { reputacional) (ISE, 2013). }\end{array}$ & 0 & 6 & 1,5 & 3 & 0 & 0 & 1,5 & 3 & 1,5 & 3 & 0 & 0 & 0 & 3 & 0 & 0 & 0 & 0 & 3 & 0 & 0 & 0 & 1,5 & 1,17 \\
\hline $\begin{array}{l}\text { 30. Considerar os valores da defesa da concorrência em suas } \\
\text { políticas corporativas (ISE, 2013). }\end{array}$ & 0 & 6 & 1,5 & 3 & 0 & 0 & 9 & 3 & 3 & 3 & 0 & 0 & 0 & 3 & 0 & 0 & 0 & 0 & 3 & 0 & 0 & 0 & 0 & 1,50 \\
\hline $\begin{array}{l}\text { 31. Elaborar processos e procedimentos implementados de gestão } \\
\text { de riscos corporativos (risco estratégico, risco operacional, risco } \\
\text { financeiro - mercado, crédito e liquidez, risco reputacional e risco } \\
\text { legal) que considerem aspectos de curto, médio e longo prazo, } \\
\text { acompanhados pelo Conselho de Administração (ISE, 2013). }\end{array}$ & 0 & 6 & 1,5 & 3 & 0 & 0 & 3 & 3 & 0 & 3 & 0 & 0 & 0 & 3 & 0 & 0 & 0 & 0 & 3 & 0 & 0 & 0 & 1,5 & $\mid \begin{array}{l}1,17 \\
\end{array}$ \\
\hline $\begin{array}{l}\text { 32. Restringir o uso de instrumentos financeiros derivativos para } \\
\text { fins exclusivos de proteção (ISE, 2013). }\end{array}$ & 0 & 0 & 0 & 3 & 0 & 0 & 3 & 3 & 3 & 3 & 0 & 3 & 0 & 9 & 0 & 0 & 0 & 0 & 3 & 0 & 0 & 0 & 0 & 1,30 \\
\hline $\begin{array}{l}\text { 33. Implementar processos e procedimentos para monitorar } \\
\text { impactos econômicos indiretos das atividades da companhia (ISE, } \\
\text { 2013). }\end{array}$ & 0 & 0 & 0 & 0 & 3 & 6 & 0 & 0 & 0 & 0 & 0 & 0 & 0 & 3 & 0 & 0 & 0 & 0 & 3 & 6 & 0 & 0 & 1,5 & 0,98 \\
\hline $\begin{array}{l}\text { 34. Elaborar processos e procedimentos implementados de gestão } \\
\text { de ativos intangíveis, além dos contabilizados (ISE, 2013). }\end{array}$ & 0 & 6 & 0 & 3 & 0 & 0 & 0 & 3 & 0 & 3 & 0 & 0 & 0 & 3 & 0 & 0 & 0 & 0 & 3 & 0 & 0 & 0 & 1,5 & 0,98 \\
\hline $\begin{array}{l}\text { 35. Possuir sistema de gestão de desempenho baseado em } \\
\text { indicadores vinculados ao planejamento estratégico (ISE, 2013). }\end{array}$ & 0 & 3 & 0 & 0 & 0 & 0 & 0 & 9 & 0 & 0 & 0 & 0 & 0 & 3 & 0 & 0 & 0 & 3 & 9 & 0 & 0 & 0 & 9 & 1,57 \\
\hline 36. Implantar medidas de defesa da concorrência (ISE, 2013). & 0 & 3 & 0 & 3 & 0 & 0 & 9 & 3 & 3 & 3 & 0 & 0 & 0 & 3 & 0 & 0 & 0 & 0 & 3 & 0 & 0 & 0 & 0 & 1,30 \\
\hline $\begin{array}{l}\text { 37. Preparar e publicar as demonstrações financeiras em moeda } \\
\text { constante (ISE, 2013) }\end{array}$ & 0 & 0 & 0 & 0 & 0 & 0 & 1,5 & 0 & 3 & 0 & 0 & 3 & 0 & 0 & 0 & 0 & 3 & 3 & 0 & 0 & 0 & 0 & 0 & 0,59 \\
\hline $\begin{array}{l}\text { 38. Calcular o lucro econômico ou outras medidas de geração de } \\
\text { valor econômico (ISE, 2013). }\end{array}$ & 0 & 0 & 0 & 0 & 0 & 0 & 1,5 & 0 & 1,5 & 0 & 0 & 0 & 0 & 0 & 0 & 0 & 1,5 & 1,5 & 0 & 0 & 0 & 0 & 0 & 0,26 \\
\hline $\begin{array}{l}\text { 39. Relatar o valor econômico direto (receitas) gerado e distribuído } \\
\text { (custos operacionais; salários e benefícios de empregados; } \\
\text { pagamentos a provedores de capital; pagamentos ao governo (por } \\
\text { país); investimentos comunitários), com base no regime de } \\
\text { competência de exercícios (GRI). }\end{array}$ & 0 & 0 & 0 & 0 & 0 & 0 & 3 & 0 & 3 & 0 & 3 & 6 & 0 & 0 & 0 & 0 & 3 & 3 & 0 & 0 & 0 & 0 & 1,5 & 0,98 \\
\hline 40. Elaborar um plano de benefícios da organização (GRI). & 0 & 0 & 3 & 0 & 0 & 0 & 3 & 3 & 3 & 0 & 3 & 3 & 0 & 0 & 0 & 0 & 0 & 0 & 3 & 0 & 0 & 0 & 1,5 & 0,98 \\
\hline MÉDIA - Requisitos NBR 16001 & 0 & 2,5 & 0,63 & 1,5 & 0,25 & 0,5 & 2,875 & 2,5 & 1,75 & 1,5 & 0,5 & 1,25 & 0 & 2,5 & 0 & 0 & 0,625 & 0,875 & 2,75 & 0,5 & 0 & 0 & 1,5 & 1,07 \\
\hline
\end{tabular}


Apêndice 20. Matriz de Relação Consolidada NBR 16001 - Dimensão socioambiental.

\begin{tabular}{|c|c|c|c|c|c|c|c|c|c|c|c|c|c|c|c|c|c|c|c|c|c|c|c|c|}
\hline \multirow[b]{2}{*}{ Requisitos da NBR 16001.} & \multirow[b]{2}{*}{$\begin{array}{l}3.1 \\
\\
\end{array}$} & \multirow[b]{2}{*}{ 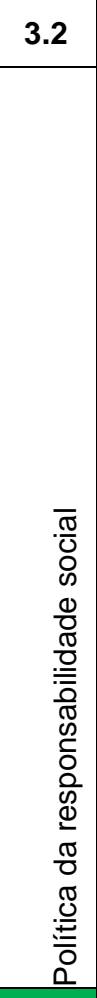 } & \multicolumn{7}{|c|}{3.3} & \multicolumn{5}{|c|}{3.4} & \multicolumn{4}{|c|}{3.5} & \multicolumn{5}{|c|}{3.6} & \multirow[b]{2}{*}{ 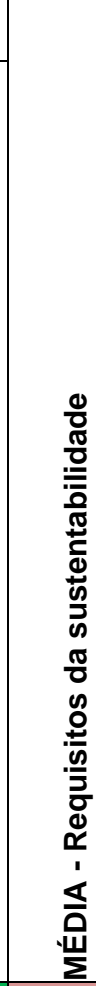 } \\
\hline & & & 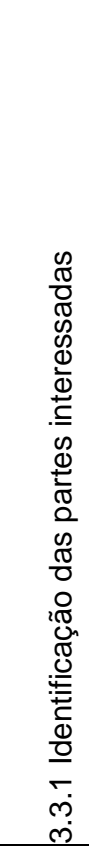 & 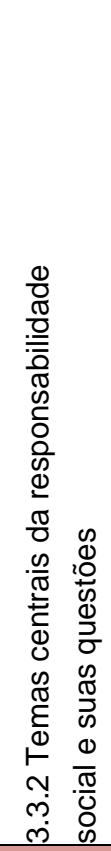 & 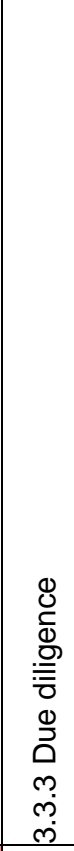 & 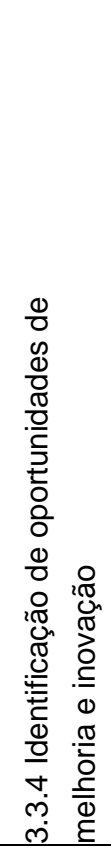 & 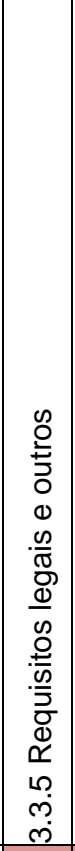 & 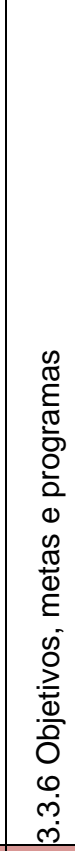 & 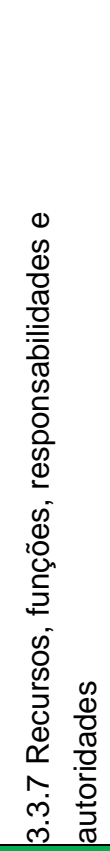 & 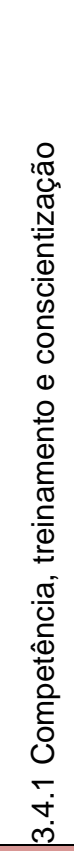 & 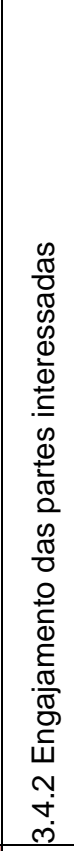 & 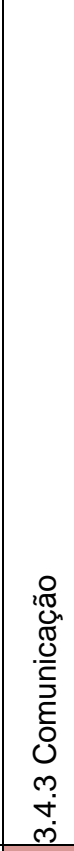 & 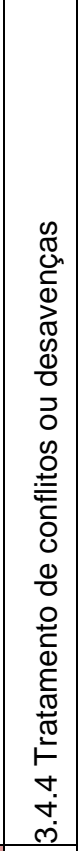 & 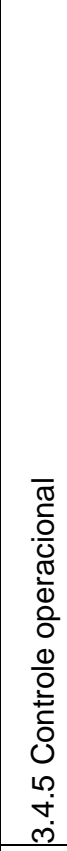 & 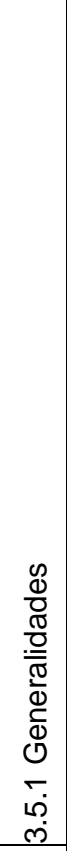 & 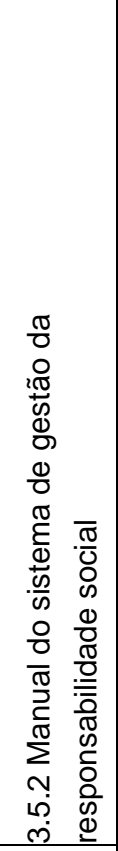 & 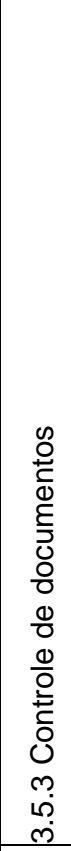 & 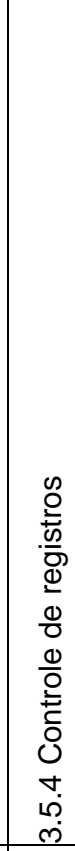 & 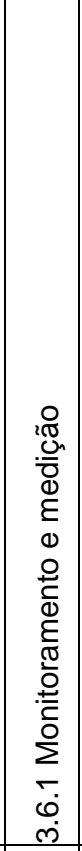 & 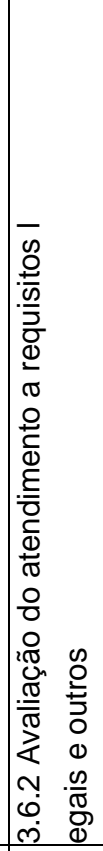 & 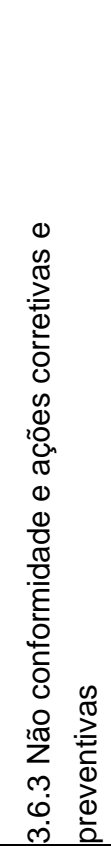 & 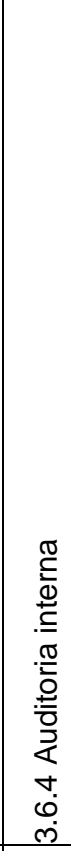 & 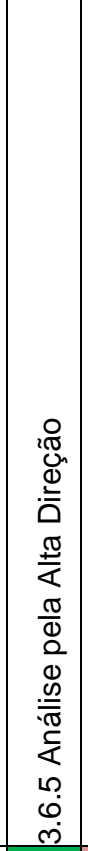 & \\
\hline $\begin{array}{l}\text { 41. Comprometimento da alta direção com as questões } \\
\text { socioambientais (Ethos, 2013). }\end{array}$ & 0 & 9 & 0 & 3 & 0 & 0 & 3 & 3 & 9 & 3 & 0 & 3 & 0 & 0 & 0 & 0 & 0 & 0 & 0 & 0 & 0 & 0 & 4,5 & 1,63 \\
\hline $\begin{array}{l}\text { 42. Incorporar critérios socioambiental na estratégia da } \\
\text { organização (Ethos, 2013). }\end{array}$ & 0 & 9 & 3 & 9 & 3 & 0 & 3 & 9 & 3 & 3 & 0 & 3 & 3 & 3 & 0 & 0 & 3 & 3 & 3 & 3 & 0 & 0 & 4,5 & 2,93 \\
\hline $\begin{array}{l}\text { 43. Comunicar a toda a organização e outras partes interessadas } \\
\text { a importância de considerar os aspectos socioambientais (Ethos, } \\
\text { 2013). }\end{array}$ & 0 & 9 & 3 & 9 & 3 & 0 & 3 & 9 & 3 & 9 & 0 & 9 & 0 & 9 & 0 & 1,5 & 0 & 0 & 9 & 3 & 0 & 0 & 1,5 & 3,52 \\
\hline $\begin{array}{l}\text { 44. A responsabilidade socioambiental deve ser repassada em } \\
\text { toda a cadeia produtiva (Ethos, 2013), (ISE, 2013) e (GRI). }\end{array}$ & 0 & 3 & 3 & 3 & 0 & 0 & 3 & 3 & 0 & 0 & 3 & 3 & 0 & 6 & 0 & 3 & 3 & 3 & 9 & 3 & 3 & 3 & 0 & 2,35 \\
\hline $\begin{array}{l}\text { 45. Possuir normas de seleção e avaliação de fornecedores que } \\
\text { contemplam critérios específicos de responsabilidade } \\
\text { socioambiental (Ethos, 2013), (ISE, 2013) e (GRI). }\end{array}$ & 0 & 3 & 3 & 3 & 0 & 0 & 3 & 3 & 0 & 0 & 3 & 3 & 0 & 6 & 0 & 3 & 3 & 3 & 9 & 3 & 3 & 3 & 0 & 2,35 \\
\hline $\begin{array}{l}\text { 46. Produzir relatórios periódicos com evidências de que questões } \\
\text { relacionadas à responsabilidade socioambiental empresarial estão } \\
\text { sendo cumpridas e implementadas em sua cadeia produtiva } \\
\text { (Ethos, 2013). }\end{array}$ & 0 & 1,5 & 0 & 1,5 & 0 & 0 & 1,5 & 1,5 & 3 & 0 & 3 & 6 & 0 & 3 & 0 & 0 & 3 & 3 & 3 & 0 & 0 & 0 & 1,5 & 1,37 \\
\hline $\begin{array}{l}\text { 47. Caso necessário treinar os fornecedores para que se adequem } \\
\text { as questões relacionadas a responsabilidade socioambiental } \\
\text { (Ethos, 2013) e (ISE, 2013). }\end{array}$ & 0 & 1,5 & 3 & 3 & 0 & 0 & 3 & 3 & 1,5 & 9 & 1,5 & 9 & 0 & 9 & 0 & 0 & 9 & 9 & 9 & 0 & 0 & 3 & 1,5 & 3,26 \\
\hline $\begin{array}{l}\text { 48. Participar de comitês/conselhos locais ou regionais para } \\
\text { discutirem a questão ambiental com o governo e a comunidade } \\
\text { (Ethos, 2013). }\end{array}$ & 0 & 4,5 & 3 & 3 & 0 & 3 & 6 & 3 & 0 & 0 & 1,5 & 3 & 0 & 0 & 0 & 0 & 0 & 0 & 0 & 3 & 0 & 0 & 1,5 & 1,37 \\
\hline $\begin{array}{l}\text { 49. Desenvolver campanhas, apoiar ou participar de projetos } \\
\text { educacionais em parceria com organizações não governamentais } \\
\text { e ambientalistas, exercendo liderança social em favor dessa causa } \\
\text { (Ethos, 2013). }\end{array}$ & 0 & 9 & 3 & 3 & 0 & 1,5 & 6 & 3 & 4,5 & 1,5 & 3 & 1,5 & 0 & 0 & 0 & 0 & 0 & 0 & 1,5 & 1,5 & 0 & 0 & 1,5 & 1,76 \\
\hline $\begin{array}{l}\text { 50. Disponibilizar suporte técnico aos consumidores finais com } \\
\text { vistas ao uso sustentável de seus produtos ou serviços (ISE, } \\
\text { 2013). }\end{array}$ & 0 & 9 & 3 & 3 & 0 & 3 & 9 & 9 & 3 & 3 & 3 & 0 & 0 & 3 & 0 & 0 & 3 & 3 & 9 & 3 & 0 & 0 & 0 & 2,87 \\
\hline $\begin{array}{l}\text { 51. Fornecer aos consumidores e clientes informações detalhadas } \\
\text { sobre danos socioambientais resultantes do uso e na destinação } \\
\text { final de seus produtos (Ethos, 2013). }\end{array}$ & 0 & 9 & 9 & 9 & 3 & 0 & 9 & 9 & 9 & 3 & 0 & 9 & 0 & 0 & 0 & 9 & 9 & 9 & 9 & 9 & 3 & 3 & 0 & 5,22 \\
\hline $\begin{array}{l}\text { 52. Divulgar informações a respeito dos aspectos e impactos } \\
\text { ambientais gerados pela organização (ISE, 2013). }\end{array}$ & 0 & 9 & 0 & 1,5 & 3 & 1,5 & 9 & 9 & 9 & 3 & 3 & 9 & 3 & 9 & 0 & 9 & 3 & 3 & 9 & 9 & 0 & 0 & 9 & 4,83 \\
\hline $\begin{array}{l}\text { 53. Mecanismos de Queixas e Reclamações Relativas a Impactos } \\
\text { Ambientais (ISE, 2013) }\end{array}$ & 0 & 9 & 1,5 & 0 & 0 & 0 & 9 & 9 & 9 & 3 & 3 & 0 & 9 & 0 & 0 & 0 & 0 & 0 & 0 & 0 & 9 & 3 & 3 & 2,93 \\
\hline MÉDIA - Requisitos NBR 16001 & 0 & 6,56 & 2,65 & 3,92 & 0,9 & 0,69 & 5,2 & 5,7 & 4,15 & 2,9 & 1,8 & 4,5 & $\mid 1,2$ & 3,7 & 0 & 1,962 & 2,8 & 2,8 & 5,4 & 2,88 & 1,38 & 1,2 & 2,2 & 2,80 \\
\hline
\end{tabular}


Apêndice 21. Matriz de Relação Consolidada NBR 16001 - Dimensão socioeconômica.

\begin{tabular}{|c|c|c|c|c|c|c|c|c|c|c|c|c|c|c|c|c|c|c|c|c|c|c|c|c|}
\hline \multirow{3}{*}{$\begin{array}{l}\text { Requisitos da sustentabilidade } \\
\text { empresarial - Dimensão socioeconômica. } \\
\text { 54. Elaborar políticas que garanta a saúde e segurança dos } \\
\text { colaboradores e outras partes interessadas (Ethos, 2013) e } \\
\text { (ISE, 2013). }\end{array}$} & \multirow[b]{2}{*}{ 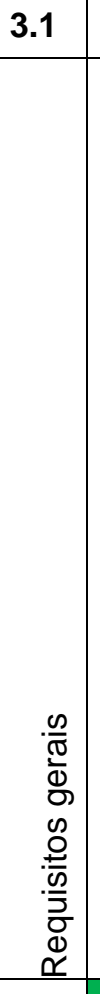 } & \multirow[b]{2}{*}{ 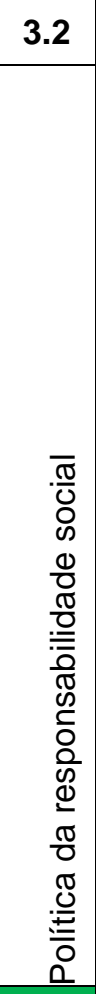 } & \multicolumn{7}{|c|}{3.3} & \multicolumn{5}{|c|}{3.4} & \multicolumn{4}{|c|}{3.5} & \multicolumn{5}{|c|}{3.6} & \multirow[b]{2}{*}{ 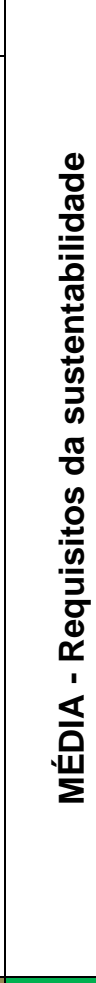 } \\
\hline & & & 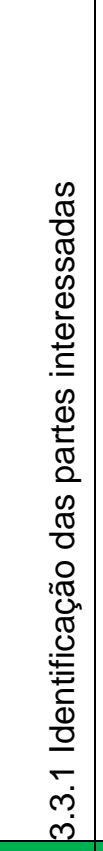 & 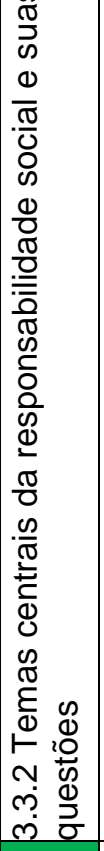 & 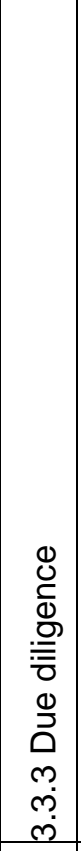 & 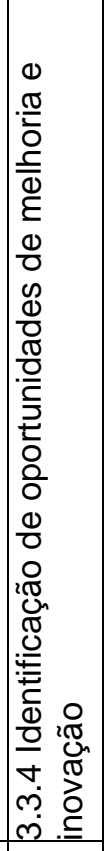 & 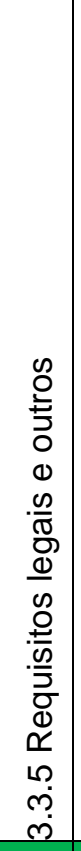 & 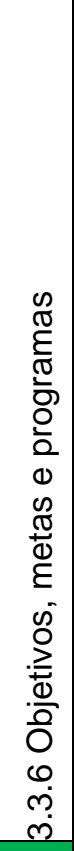 & 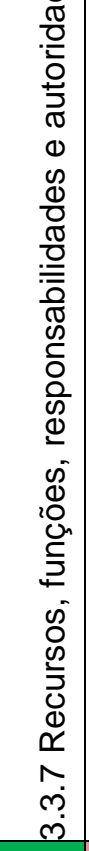 & 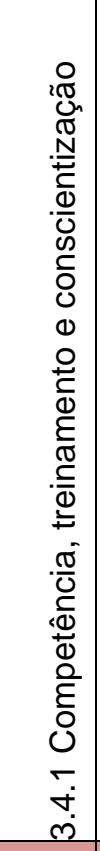 & 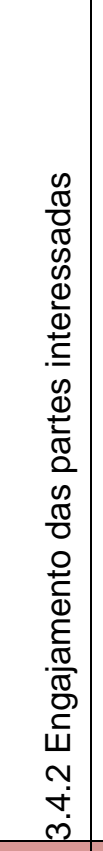 & 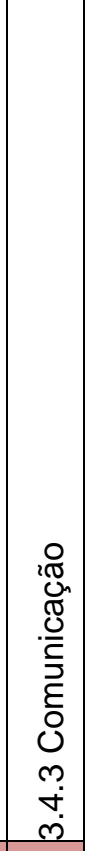 & 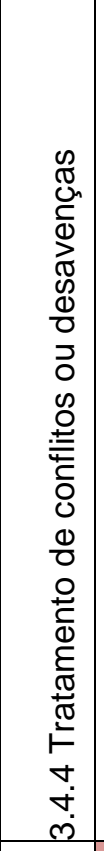 & 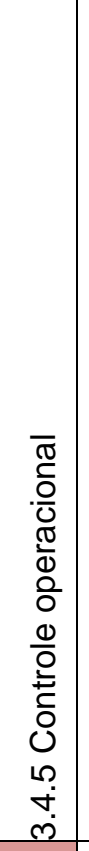 & 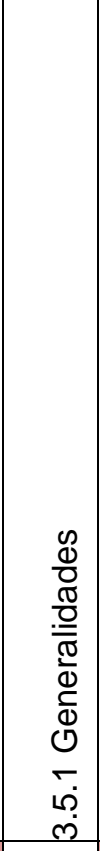 & 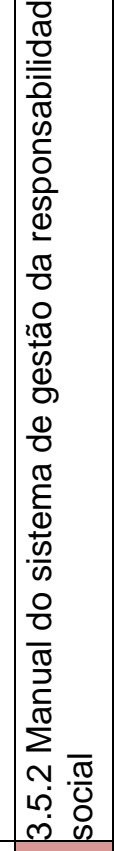 & 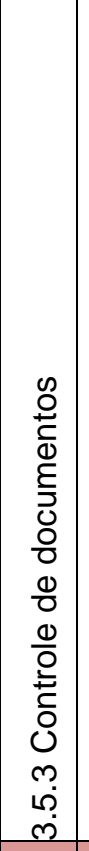 & 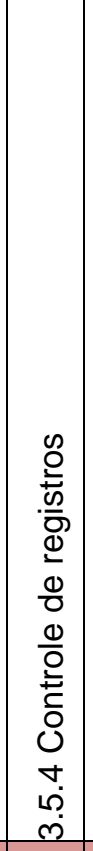 & 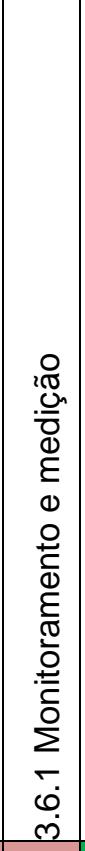 & 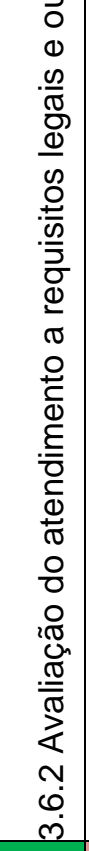 & 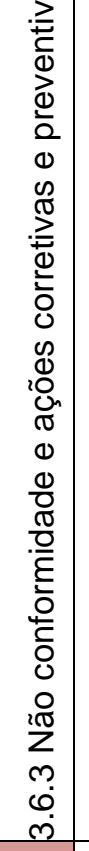 & 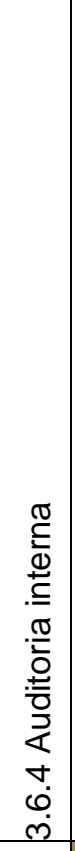 & 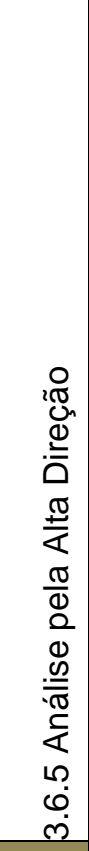 & \\
\hline & 0 & 9 & 9 & 9 & 0 & 0 & 9 & 9 & 9 & 3 & 3 & 3 & 0 & 3 & 0 & 3 & 3 & 3 & 3 & 9 & 3 & 0 & 1,5 & 3,98 \\
\hline $\begin{array}{l}\text { 55. Elaborar políticas trabalhistas, remuneração, benefícios } \\
\text { e carreira (Ethos, 2013), (ISE, 2013) e (GRI, 211). }\end{array}$ & 0 & 9 & 9 & 9 & 0 & 0 & 9 & 9 & 9 & 3 & 3 & 3 & 0 & 3 & 0 & 3 & 3 & 3 & 3 & 9 & 3 & 0 & 1,5 & 3,98 \\
\hline $\begin{array}{l}\text { 56. Elaborar política(s) que aborde(m) as questões } \\
\text { relacionadas aos clientes (Ethos, 2013), (ISE, 2013) e (GRI). }\end{array}$ & 0 & 9 & 9 & 9 & 0 & 1,5 & 6 & 6 & 6 & 3 & 3 & 3 & 1,5 & 3 & 1,5 & 3 & 3 & 3 & 3 & 6 & 3 & 0 & 1,5 & 3,65 \\
\hline $\begin{array}{l}\text { 57. Oferecer condições de trabalho ideal para os } \\
\text { colaboradores, terceirizados e outras partes interessadas } \\
\text { (treinamentos, infraestrutura, incentivos, desenvolvimento } \\
\text { profissional, entre outros) (Ethos, 2013) e (ISE, 2013). }\end{array}$ & 0 & 9 & 9 & 9 & 3 & 0 & 9 & 9 & 9 & 3 & 3 & 3 & 0 & 3 & 0 & 3 & 3 & 3 & 3 & 9 & 3 & 0 & 3 & 4,17 \\
\hline $\begin{array}{l}\text { 58. Manter um canal de diálogo com os clientes, } \\
\text { funcionários, fornecedores e distribuidores (Ethos, 2013), } \\
\text { (ISE, 2013) e (GRI). }\end{array}$ & 0 & 9 & 9 & 1,5 & 0 & 1,5 & 0 & 3 & 3 & 3 & 9 & 9 & 3 & 3 & 0 & 0 & 0 & 0 & 3 & 0 & 0 & 0 & 3 & 2,61 \\
\hline $\begin{array}{l}\text { 59. Incluir entre seus fornecedores indivíduos ou grupos da } \\
\text { comunidade, tais como cooperativas de pequenos } \\
\text { produtores ou de iniciativas solidárias, associações de bairro } \\
\text { e organizações com projetos de geração de renda para } \\
\text { grupos usualmente excluídos (populações indígenas, } \\
\text { pessoas com deficiência etc.) (Ethos, 2013) (ISE, 2013) e } \\
\text { (GRI). }\end{array}$ & 0 & 4,5 & 9 & 3 & 3 & 3 & 9 & 3 & 3 & 0 & 0 & 3 & 0 & 0 & 0 & 3 & 3 & 3 & 3 & 0 & 0 & 0 & 1,5 & 2,35 \\
\hline $\begin{array}{l}\text { 60. Elaborar programa de mapeamento para identificação de } \\
\text { competências potenciais a serem desenvolvidas (Ethos, } \\
\text { 2013). }\end{array}$ & 0 & 3 & 1,5 & 3 & 0 & 1,5 & 0 & 3 & 3 & 9 & 9 & 3 & 0 & 3 & 0 & 0 & 0 & 0 & 3 & 0 & 0 & 0 & 3 & 1,96 \\
\hline $\begin{array}{l}\text { 61. Identificar empregados com alta incidência ou alto risco } \\
\text { de doenças relacionadas à sua ocupação (GRI) }\end{array}$ & 0 & 3 & 9 & 9 & 0 & 0 & 9 & 9 & 9 & 3 & 3 & 3 & 0 & 9 & 0 & 0 & 3 & 3 & 3 & 9 & 3 & 0 & 3 & 3,91 \\
\hline $\begin{array}{l}\text { 62. Adotar política contínua de esclarecimento aos } \\
\text { funcionários sobre defesa da concorrência (ISE, 2013). }\end{array}$ & 0 & 3 & 3 & 3 & 3 & 0 & 3 & 3 & 3 & 6 & 0 & 9 & 0 & 9 & 0 & 0 & 0 & 0 & 9 & 0 & 0 & 0 & 3 & 2,48 \\
\hline $\begin{array}{l}\text { 63. Manter os valores dos salários dos colaboradores sem } \\
\text { distinção de gênero (GRI). }\end{array}$ & 0 & 3 & 9 & 9 & 0 & 1,5 & 9 & 9 & 9 & 3 & 3 & 3 & 0 & 9 & 0 & 0 & 3 & 3 & 3 & 9 & 3 & 0 & 3 & 3,98 \\
\hline MÉDIA - Requisitos NBR 16001 & 0 & 6,15 & 7,65 & 6,45 & 0,9 & 0,9 & 6,3 & 6,3 & 6,3 & 3,6 & 3,6 & 4,2 & 0,45 & 4,5 & 0,15 & 1,5 & 2,1 & 2,1 & 3,6 & 5,1 & 1,8 & 0 & 2,4 & 3,31 \\
\hline
\end{tabular}


Apêndice 22. Matriz de Relação Consolidada NBR 16001 - Dimensão econômica - ambiental.

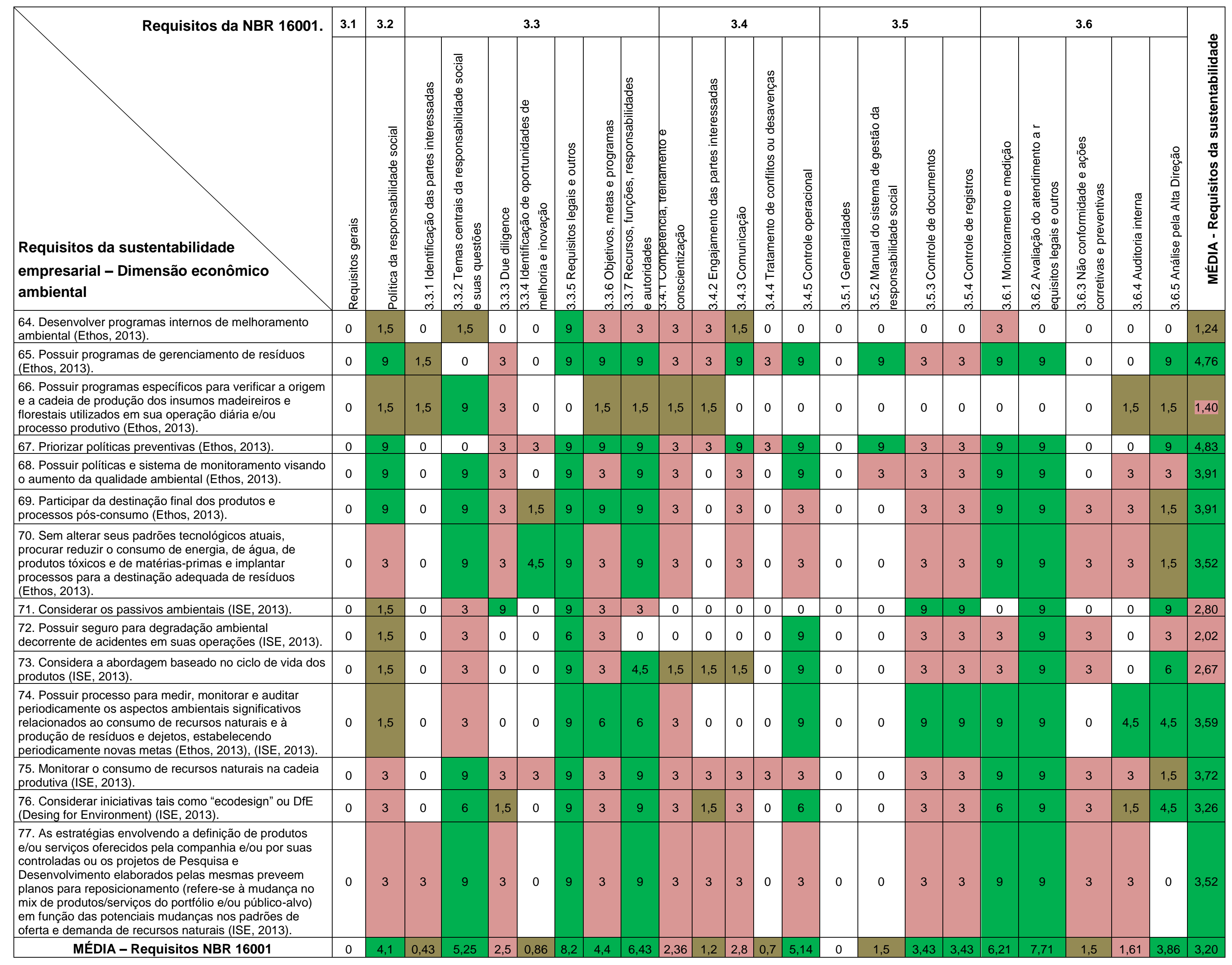


Apêndice 23. Matriz de Relação Consolidada NBR 16001 - Dimensão ambiental - social- econômica.

\begin{tabular}{|c|c|c|c|c|c|c|c|c|c|c|c|c|c|c|c|c|c|c|c|c|c|c|c|c|}
\hline \multirow{3}{*}{$\begin{array}{l}\text { Requisitos da sustentabilidade } \\
\text { empresarial - Dimensão ambiental - } \\
\text { social - econômica. }\end{array}$} & \multirow[b]{2}{*}{ 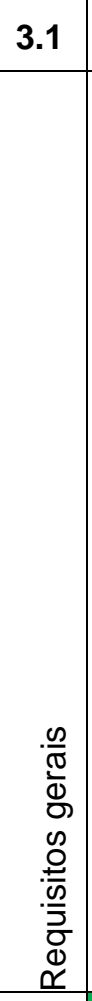 } & \multirow[b]{2}{*}{ 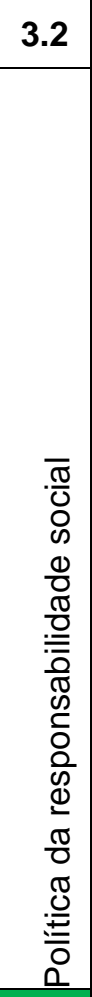 } & \multicolumn{7}{|c|}{3.3} & \multicolumn{5}{|c|}{3.4} & \multicolumn{4}{|c|}{3.5} & \multicolumn{5}{|c|}{3.6} & \multirow[b]{2}{*}{ 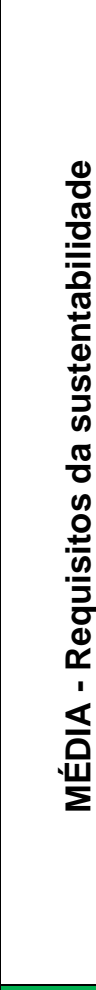 } \\
\hline & & & 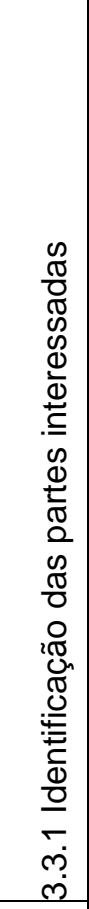 & 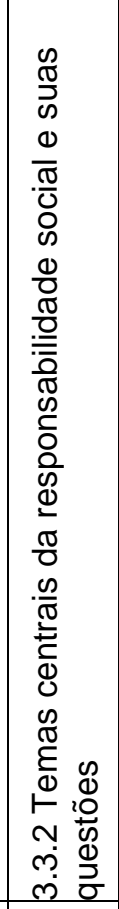 & 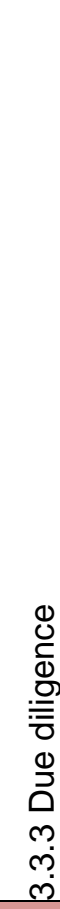 & 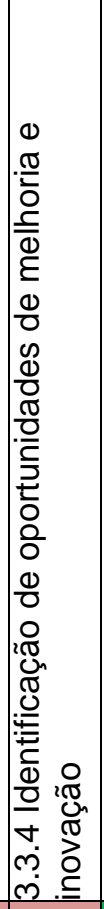 & 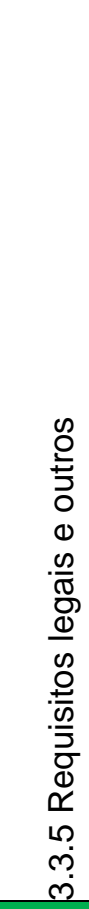 & 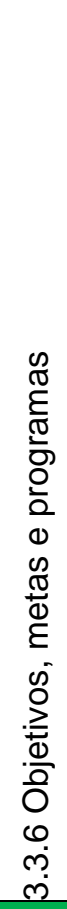 & 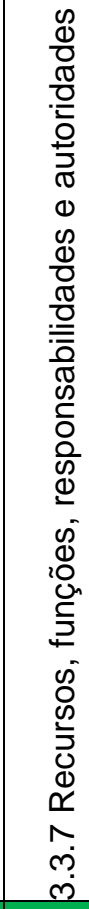 & 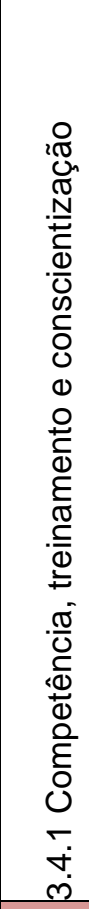 & 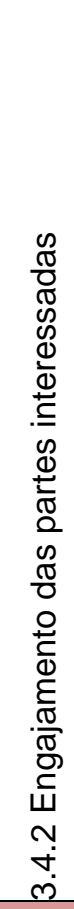 & 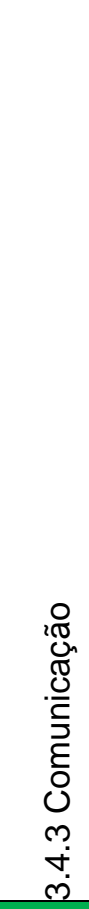 & 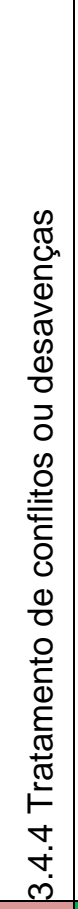 & 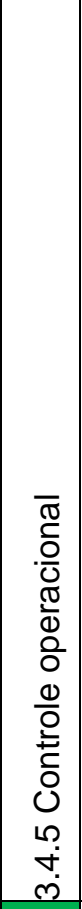 & 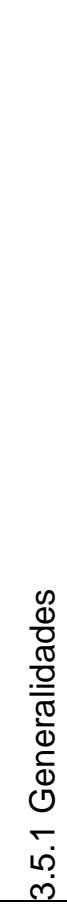 & 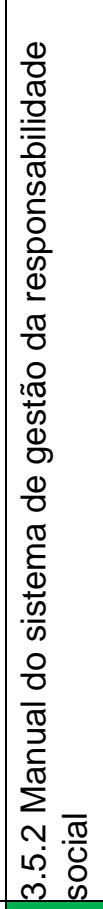 & 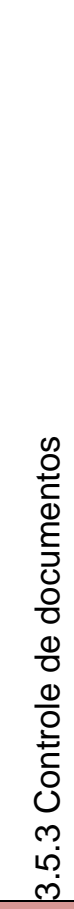 & 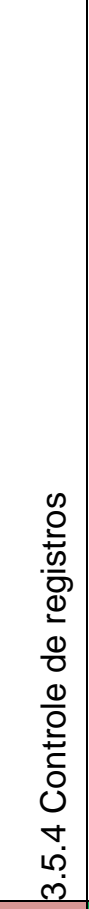 & 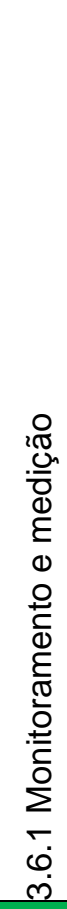 & 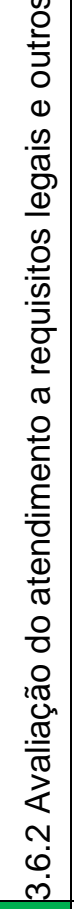 & 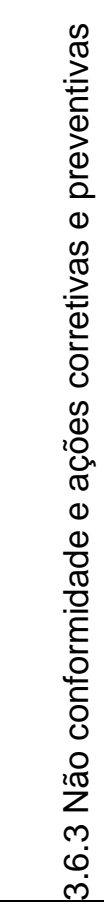 & 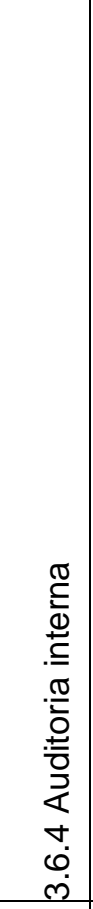 & 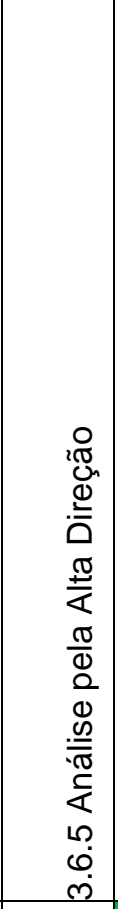 & \\
\hline & 0 & 9 & 0 & 0 & 3 & 3 & 9 & 9 & 9 & 3 & 3 & 9 & 3 & 9 & 0 & 9 & 3 & 3 & 9 & 9 & 0 & 0 & 0 & 4,43 \\
\hline 79. Assumir uma postura ética (Ethos, 2013). & 0 & 9 & 0 & 1,5 & 3 & 3 & 9 & 9 & 9 & 3 & 3 & 9 & 3 & 9 & 0 & 9 & 3 & 3 & 9 & 9 & 0 & 0 & 4,5 & 4,70 \\
\hline $\begin{array}{l}\text { 80. Identificar as partes interessadas e conhecer o } \\
\text { contexto em que cada parte está inserida para que as } \\
\text { mesmas possam auxiliar na mitigação dos impactos } \\
\text { socioambientais envolvidos em cada contexto (Ethos, } \\
\text { 2013) e (ISE, 2013). }\end{array}$ & 0 & 9 & 9 & 9 & 0 & 0 & 9 & 9 & 3 & 3 & 9 & 9 & 3 & 0 & 0 & 0 & 0 & 0 & 0 & 3 & 0 & 0 & 9 & 3,65 \\
\hline $\begin{array}{l}\text { 81. Manter o diálogo com as partes interessadas } \\
\text { (Ethos, 2013) (ISE, 2013) e (GRI). }\end{array}$ & 0 & 9 & 9 & 9 & 0 & 0 & 9 & 9 & 3 & 3 & 9 & 9 & 9 & 0 & 0 & 0 & 0 & 0 & 0 & 3 & 0 & 0 & 9 & 3,91 \\
\hline $\begin{array}{l}\text { 82. Monitorar os impactos causados por suas atividades } \\
\text { na comunidade de entorno (Ethos, 2013). }\end{array}$ & 0 & 9 & 9 & 9 & 0 & 0 & 9 & 9 & 3 & 3 & 3 & 9 & 9 & 9 & 0 & 0 & 3 & 3 & 9 & 3 & 0 & 0 & 9 & 4,70 \\
\hline $\begin{array}{l}\text { 83. Possuir conselho ou responsável formal por } \\
\text { questões éticas internas e externas e garantir a } \\
\text { gerência eficaz (Ethos, 2013) e (ISE, 2013). }\end{array}$ & 0 & 0 & 0 & 3 & 0 & 0 & 3 & 9 & 9 & 9 & 3 & 9 & 9 & 0 & 0 & 0 & 0 & 0 & 3 & 0 & 0 & 0 & 3 & 2,61 \\
\hline $\begin{array}{l}\text { 84. Não praticar concorrência desleal (Ethos, 2013) e } \\
\text { (GRI). }\end{array}$ & 0 & 9 & 0 & 9 & 0 & 0 & 9 & 3 & 3 & 3 & 0 & 0 & 0 & 3 & 0 & 0 & 0 & 0 & 3 & 0 & 0 & 0 & 4,5 & 2,02 \\
\hline $\begin{array}{l}\text { 85. Cumprir a legislação e pagamentos de tributos } \\
\text { (Ethos, 2013) e (ISE, 2013). }\end{array}$ & 0 & 9 & 3 & 9 & 3 & 0 & 9 & 3 & 0 & 0 & 0 & 0 & 0 & 9 & 0 & 0 & 3 & 3 & 9 & 0 & 0 & 0 & 6 & 2,87 \\
\hline $\begin{array}{l}\text { 86. Comunicar o compromisso com o desenvolvimento } \\
\text { sustentável (ISE, 2013). }\end{array}$ & 0 & 6 & 3 & 0 & 0 & 0 & 9 & 9 & 9 & 3 & 3 & 9 & 0 & 0 & 0 & 3 & 3 & 3 & 0 & 0 & 0 & 3 & 6 & 3,00 \\
\hline 87. Definir responsabilidades e autoridades (ISE, 2013). & 0 & 6 & 3 & 0 & 0 & 0 & 9 & 9 & 9 & 9 & 0 & 9 & 0 & 0 & 0 & 3 & 3 & 3 & 0 & 0 & 0 & 0 & 3 & 2,87 \\
\hline $\begin{array}{l}\text { 88. Existir processos e procedimentos implementados } \\
\text { para gestão de oportunidades corporativas que } \\
\text { considere aspectos socioambientais de curto, médio e } \\
\text { longo prazo (ISE, 2013). }\end{array}$ & 0 & 3 & 3 & 0 & 0 & 9 & 0 & 9 & 9 & 3 & 0 & 0 & 0 & 0 & 0 & 3 & 3 & 3 & 9 & 0 & 0 & 1,5 & 0 & 2,41 \\
\hline $\begin{array}{l}\text { 89. Possuir plano de contigência que considere } \\
\text { desastres naturais, impactos ambientais, impactos } \\
\text { sociais, impactos em infraestrutura/operacionais } \\
\text { (incluindo TI) (ISE, 2013). }\end{array}$ & 0 & 9 & 3 & 9 & 3 & 0 & 9 & 9 & 9 & 3 & 3 & 3 & 0 & 3 & 0 & 0 & 3 & 3 & 9 & 9 & 9 & 0 & 1,5 & 4,24 \\
\hline MÉDIA - Requisitos NBR 16001 & 0 & 7,25 & 3,5 & 4,875 & 1 & 1,25 & 7,75 & 8 & 6,25 & 3,75 & 3 & 6,25 & 3 & 3,5 & 0 & 2,25 & 2 & 2 & 5 & 3 & 0,75 & 0,38 & 4,625 & 3,451 \\
\hline
\end{tabular}


Apêndice 24. Matriz de Relação Consolidada OHSAS 18001 - Dimensão social.

\begin{tabular}{|c|c|c|c|c|c|c|c|c|c|c|c|c|c|c|c|c|c|c|c|}
\hline \multirow[b]{2}{*}{$\begin{array}{l}\text { Requisitos da sustentabilidade } \\
\text { empresarial - Dimensão social }\end{array}$} & \multirow[b]{2}{*}{ 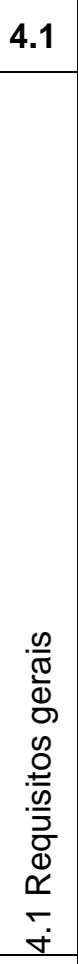 } & \multirow[b]{2}{*}{ 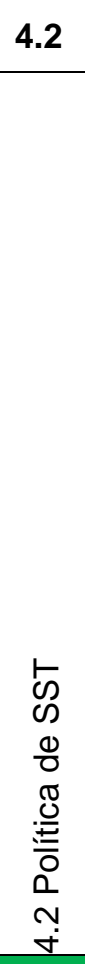 } & \multicolumn{3}{|c|}{4.3} & \multicolumn{7}{|c|}{4.4} & \multicolumn{5}{|c|}{4.5} & \multirow[b]{2}{*}{ 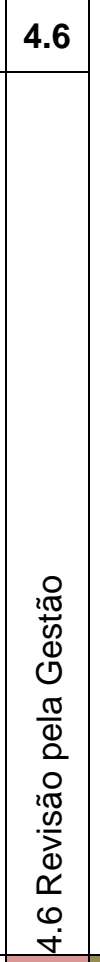 } & \multirow[b]{2}{*}{ 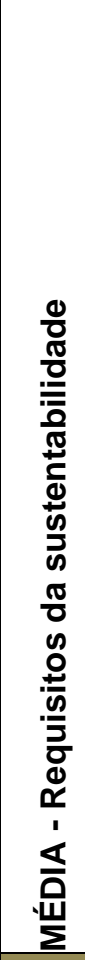 } \\
\hline & & & 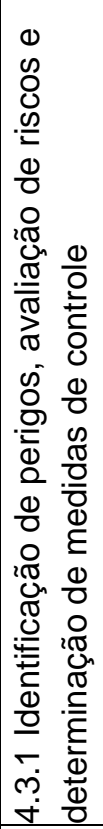 & 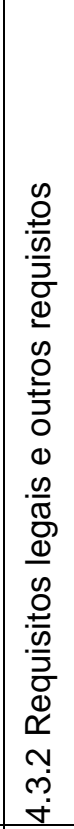 & 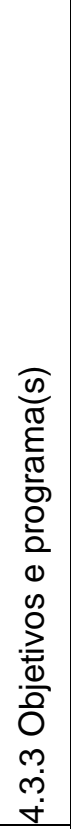 & 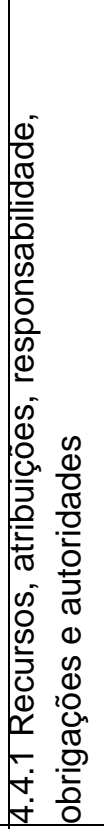 & 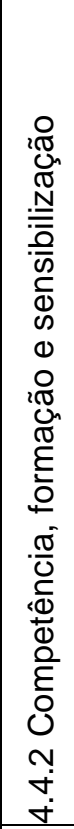 & 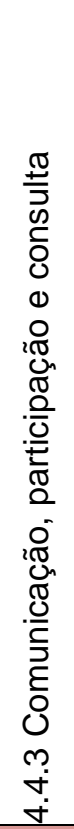 & 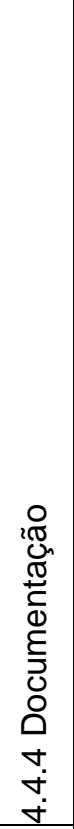 & 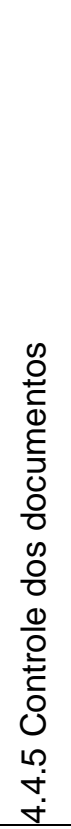 & $\begin{array}{l}\bar{\pi} \\
\overline{0} \\
\frac{0}{0} \\
\frac{\pi}{0} \\
\frac{0}{0} \\
\frac{0}{0} \\
\frac{0}{0} \\
\overline{0} \\
0 \\
0 \\
\dot{+}\end{array}$ & 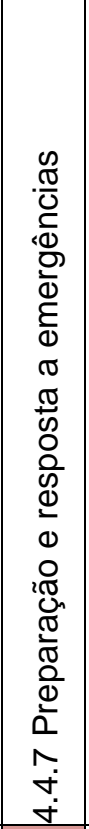 & 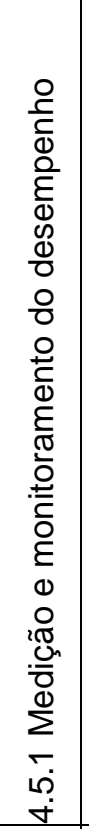 & 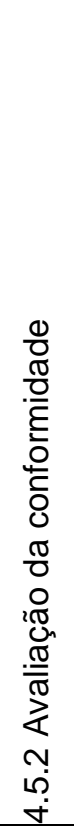 & 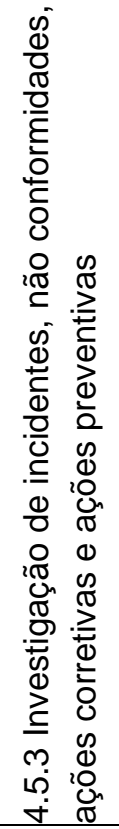 & 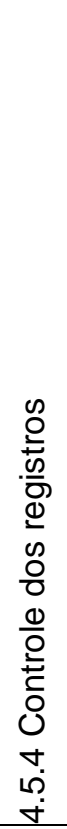 & 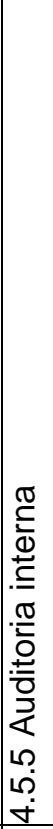 & & \\
\hline $\begin{array}{l}\text { 1. Elaborar política para que os indicadores/dados/informações advindos do processo de diálogo e } \\
\text { engajamento das partes interessadas sejam, preservadas (quando confidencial), comparáveis, confiáveis, } \\
\text { relevantes e compreensíveis por suas partes interessadas (Ethos, 2013) e (ISE, 2013). }\end{array}$ & 0 & 9 & 0 & 0 & 0 & 0 & 0 & 3 & 0 & 0 & 0 & 3 & 0 & 0 & 0 & 0 & 0 & 3 & 1 \\
\hline $\begin{array}{l}\text { 2. Valorizar a diversidade, equidade e não discriminação ( racial, gênero, opção sexual ou qualquer outra } \\
\text { forma de discriminação) (Ethos, 2013), (ISE, 2013) e (GRI). }\end{array}$ & 0 & 0 & 0 & 0 & 0 & 0 & 0 & 0 & 0 & 0 & 0 & 0 & 0 & 0 & 0 & 0 & 0 & 0 & 0 \\
\hline 3.Considerar a responsabilidade social na cadeia de fornecimento (Ethos, 2013) e (ISE, 2013). & 0 & 0 & 0 & 0 & 0 & 0 & 0 & 0 & 0 & 0 & 3 & 0 & 0 & 0 & 0 & 0 & 0 & 0 & 0,17 \\
\hline 4. Engajar as partes interessadas (Ethos, 2013) e (ISE, 2013). & 0 & 3 & 3 & 3 & 0 & 0 & 3 & 9 & 0 & 0 & 3 & 9 & 0 & 0 & 0 & 0 & 0 & 0 & 1,83 \\
\hline $\begin{array}{l}\text { 5. Participar do processo de elaboração, avaliação, implantação ou monitoramento de políticas públicas } \\
\text { (Ethos, 2013), (ISE, 2013) e (GRI). }\end{array}$ & 0 & 0 & 0 & 0 & 0 & 0 & 0 & 0 & 0 & 0 & 0 & 0 & 0 & 0 & 0 & 0 & 0 & 0 & 0 \\
\hline $\begin{array}{l}\text { 6. Apoiar, patrocinar e desenvolver projetos, programas, campanhas e pesquisas científicas (Ethos, 2013), } \\
\text { (ISE, 2013) e (GRI). }\end{array}$ & 0 & 0 & 0 & 0 & 0 & 0 & 0 & 0 & 0 & 0 & 0 & 0 & 0 & 0 & 0 & 0 & 0 & 0 & 0 \\
\hline 7. Oferecer oportunidade de trabalho para grupos vulneráveis (Ethos, 2013). & 0 & 0 & 0 & 0 & 0 & 0 & 0 & 0 & 0 & 0 & 0 & 0 & 0 & 0 & 0 & 0 & 0 & 0 & 0 \\
\hline 8. Estimular os funcionários a cumprirem os valores e princípios éticos da organização (Ethos, 2013). & 0 & 3 & 0 & 0 & 0 & 0 & 3 & 3 & 0 & 0 & 0 & 0 & 0 & 0 & 0 & 0 & 0 & 0 & 0,5 \\
\hline 9. Garantir o atendimento dos direitos humanos (GRI). & 0 & 0 & 0 & 3 & 0 & 0 & 0 & 0 & 0 & 0 & 0 & 0 & 0 & 0 & 0 & 0 & 0 & 0 & 0,17 \\
\hline $\begin{array}{l}\text { 10.Elaborar programas de aconselhamento sobre o planejamento de carreiras, de forma a auxiliar os } \\
\text { empregados na reflexão sobre suas funções e identificação de objetivos em longo prazo (Ethos, 2013). }\end{array}$ & 0 & 0 & 0 & 0 & 0 & 0 & 3 & 0 & 0 & 0 & 0 & 0 & 0 & 0 & 0 & 0 & 0 & 0 & 0,17 \\
\hline $\begin{array}{l}\text { 11.Elaborar programa sistemático de preparação interna, oferecendo oportunidades de aproveitamento da } \\
\text { capacidade de trabalho dos aposentados (Ethos, 2013). }\end{array}$ & 0 & 0 & 0 & 0 & 0 & 0 & 0 & 0 & 0 & 0 & 0 & 0 & 0 & 0 & 0 & 0 & 0 & 0 & 0 \\
\hline $\begin{array}{l}\text { 12.Elaborar programa para empregar, na medida do possível, o maior número de moradores do local em } \\
\text { que está inserida, dando-lhes formação, com o objetivo de aumentar os níveis de qualificação daquela } \\
\text { comunidade, em cooperação com sindicatos, ONGs, representantes da comunidade ou autoridades } \\
\text { públicas competentes (Ethos, 2013) e (ISE, 2013). }\end{array}$ & 0 & 0 & 0 & 0 & 0 & 0 & 0 & 0 & 0 & 0 & 0 & 0 & 0 & 0 & 0 & 0 & 0 & 0 & 0 \\
\hline 13. Elaborar programa específico de contratação de pessoas com deficiência (Ethos, 2013). & 0 & 0 & 0 & 0 & 0 & 0 & 0 & 0 & 0 & 0 & 0 & 0 & 0 & 0 & 0 & 0 & 0 & 0 & 0 \\
\hline $\begin{array}{l}\text { 14. Identificar os tipos e taxas de lesões, doenças ocupacionais, dias perdidos, absenteísmo e número de } \\
\text { óbitos relacionados ao trabalho, discriminados por região e gênero (GRI). }\end{array}$ & 0 & 0 & 0 & 0 & 0 & 0 & 0 & 0 & 0 & 0 & 0 & 0 & 9 & 0 & 0 & 0 & 0 & 0 & 0,5 \\
\hline $\begin{array}{l}\text { 15. Estabelecer acordos formais entre as empresas, sindicatos e colaboradores para manter o direito dos } \\
\text { colaboradores (GRI). }\end{array}$ & 0 & 0 & 0 & 0 & 0 & 0 & 0 & 0 & 0 & 0 & 0 & 0 & 0 & 0 & 0 & 0 & 0 & 0 & 0 \\
\hline MÉDIA - Requisitos OHSAS 18001 & 0 & 1 & 0,2 & 0,4 & 0 & 0 & 0,6 & 1 & 0 & 0 & 0,4 & 0,8 & 0,6 & 0 & 0 & 0 & 0 & 0,2 & 0,29 \\
\hline
\end{tabular}


Apêndice 25. Matriz de Relação Consolidada OHSAS 18001 - Dimensão ambiental.

\begin{tabular}{|c|c|c|c|c|c|c|c|c|c|c|c|c|c|c|c|c|c|c|c|}
\hline \multirow[b]{2}{*}{$\begin{array}{l}\text { Requisitos da sustentabilidade } \\
\text { empresarial - Dimensão ambiental }\end{array}$} & \multirow[b]{2}{*}{ 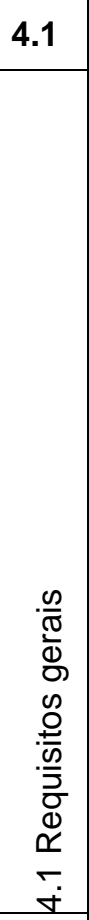 } & \multirow[b]{2}{*}{ 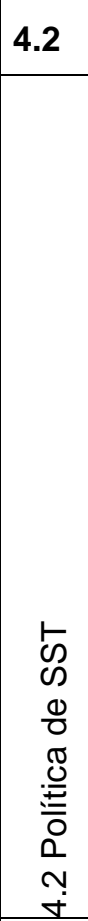 } & \multicolumn{3}{|l|}{4.3} & \multicolumn{7}{|l|}{4.4} & \multicolumn{5}{|l|}{4.5} & \multirow[b]{2}{*}{ 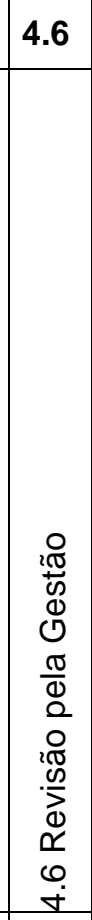 } & \multirow[b]{2}{*}{ 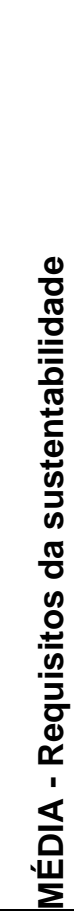 } \\
\hline & & & 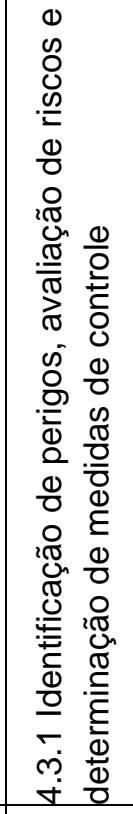 & 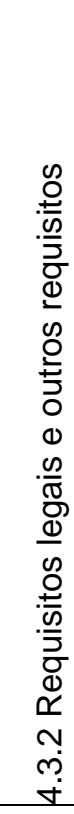 & 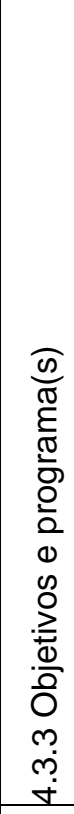 & 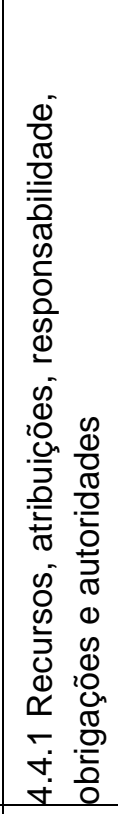 & 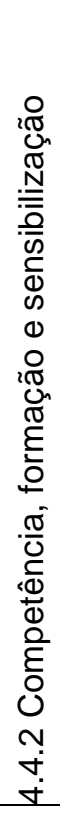 & 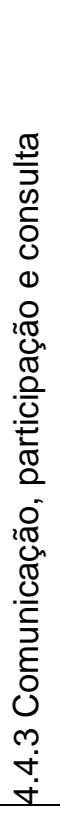 & 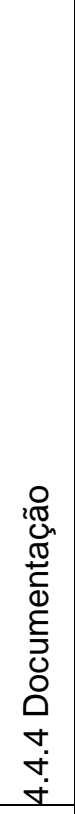 & 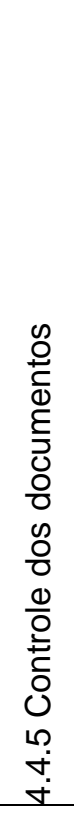 & 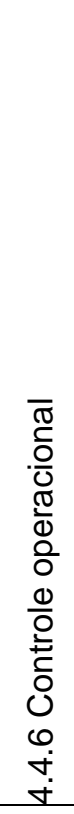 & 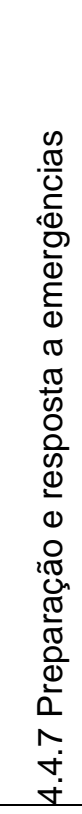 & 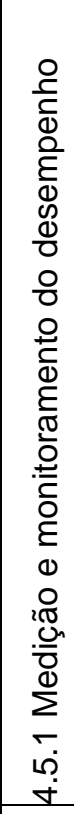 & 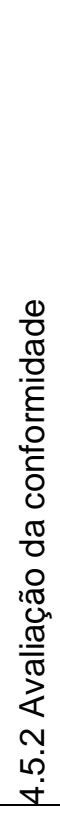 & 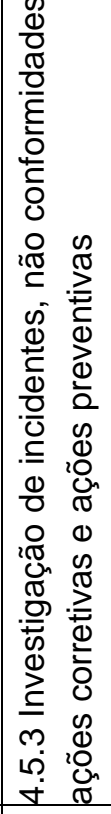 & 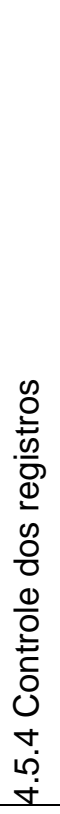 & 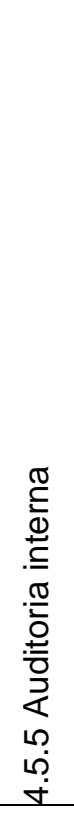 & & \\
\hline $\begin{array}{l}\text { 16. Garantir a preservação das Áreas de Preservação Permanente (APP) (ISE, } \\
\text { 2013). }\end{array}$ & 0 & 0 & 0 & 0 & 0 & 0 & 0 & 0 & 0 & 0 & 0 & 0 & 0 & 0 & 0 & 0 & 0 & 0 & 0 \\
\hline 17. Delimitar a área de Reserva Legal em situações aplicáveis (ISE, 2013). & 0 & 0 & 0 & 0 & 0 & 0 & 0 & 0 & 0 & 0 & 0 & 0 & 0 & 0 & 0 & 0 & 0 & 0 & 0 \\
\hline $\begin{array}{l}\text { 18. Possuir todas as licenças necessárias no licenciamento ambiental (ISE, } \\
\text { 2013). }\end{array}$ & 0 & 0 & 0 & 0 & 0 & 0 & 0 & 0 & 0 & 0 & 0 & 0 & 0 & 0 & 0 & 0 & 0 & 0 & 0 \\
\hline 19. Considerar a questão das mudanças climáticas (ISE, 2013). & 0 & 0 & 0 & 0 & 0 & 0 & 0 & 0 & 0 & 0 & 0 & 0 & 0 & 0 & 0 & 0 & 0 & 0 & 0 \\
\hline $\begin{array}{l}\text { 20. Elaborar Política Ambiental (deve ser formal, de conhecimento de todos os } \\
\text { empregados e constar no código de conduta e/ou na declaração de valores das } \\
\text { empresas) (Ethos, 2013) e (ISE, 2013). }\end{array}$ & 0 & 0 & 0 & 0 & 0 & 0 & 0 & 0 & 0 & 0 & 0 & 0 & 0 & 0 & 0 & 0 & 0 & 0 & 0 \\
\hline $\begin{array}{l}\text { 21. Contribuir para a preservação da biodiversidade por meio de políticas } \\
\text { específicas (Ethos, 2013) e (ISE, 2013). }\end{array}$ & 0 & 0 & 0 & 0 & 0 & 0 & 0 & 0 & 0 & 0 & 0 & 0 & 0 & 0 & 0 & 0 & 0 & 0 & 0 \\
\hline 22. Possuir área ou comitê responsável pelo meio ambiente (Ethos, 2013). & 0 & 0 & 0 & 0 & 0 & 0 & 0 & 0 & 0 & 0 & 0 & 0 & 0 & 0 & 0 & 0 & 0 & 0 & 0 \\
\hline $\begin{array}{l}\text { 23. Exigir estudos de impacto ambiental em toda a cadeia produtiva (Ethos, } \\
\text { 2013). }\end{array}$ & 0 & 0 & 0 & 0 & 0 & 0 & 0 & 0 & 0 & 0 & 0 & 0 & 0 & 0 & 0 & 0 & 0 & 0 & 0 \\
\hline $\begin{array}{l}\text { 24. Possuir planos de emergência ambiental, que relacionem todos os seus } \\
\text { processos e produtos ou serviços que envolvam situações de risco, e treinar } \\
\text { seus empregados regularmente para enfrentar tais situações (Ethos, 2013). }\end{array}$ & 0 & 0 & 0 & 0 & 0 & 0 & 0 & 0 & 0 & 0 & 0 & 9 & 0 & 0 & 0 & 0 & 0 & 0 & 0,5 \\
\hline 25.Identificar e monitorar os riscos e os aspectos ambientais (Ethos, 2013). & 0 & 0 & 0 & 0 & 3 & 0 & 0 & 0 & 0 & 0 & 0 & 0 & 0 & 0 & 0 & 0 & 0 & 0 & 0,17 \\
\hline 26. Elaborar planos de ações (Ethos, 2013). & 0 & 0 & 0 & 0 & 3 & 0 & 0 & 0 & 0 & 0 & 0 & 0 & 0 & 0 & 0 & 0 & 0 & 0 & 0,17 \\
\hline 27. Divulgar o inventário de emissões de GEE (ISE, 2013). & 0 & 0 & 0 & 0 & 0 & 0 & 0 & 0 & 0 & 0 & 0 & 0 & 0 & 0 & 0 & 0 & 0 & 0 & 0 \\
\hline $\begin{array}{l}\text { 28. Os processos de gestão da companhia devem incorporar o uso sustentável } \\
\text { dos recursos naturais renováveis como requisito prioritário (ISE, 2013). }\end{array}$ & 0 & 0 & 0 & 0 & 0 & 0 & 0 & 0 & 0 & 0 & 0 & 0 & 0 & 0 & 0 & 0 & 0 & 0 & 0 \\
\hline MÉDIA - Requisitos OHSAS 18001 & 0 & 0 & 0 & 0 & 0,5 & 0 & 0 & 0 & 0 & 0 & 0 & 0,7 & 0 & 0 & 0 & 0 & 0 & 0 & 0,06 \\
\hline
\end{tabular}


Apêndice 26. Matriz de Relação Consolidada OHSAS 18001 - Dimensão econômica.

\begin{tabular}{|c|c|c|c|c|c|c|c|c|c|c|c|c|c|c|c|c|c|c|c|}
\hline & 4.1 & 4.2 & & 4.3 & & & & & & & & & & & 4.5 & & & 4.6 & \\
\hline $\begin{array}{l}\text { Requisitos da sustentabilidade } \\
\text { empresarial - Dimensão econômica }\end{array}$ & 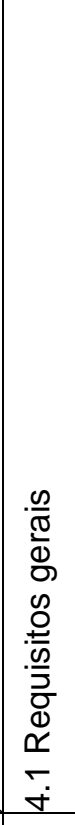 & 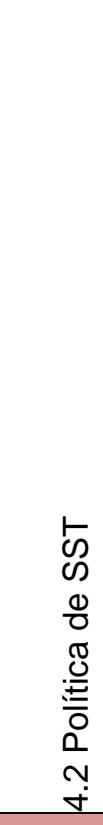 & 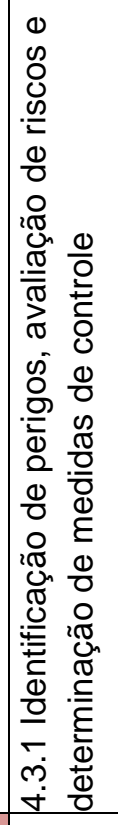 & 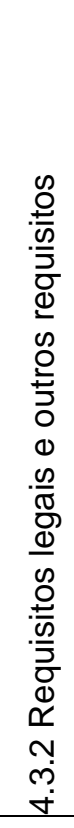 & 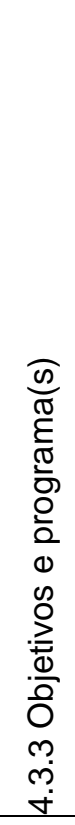 & 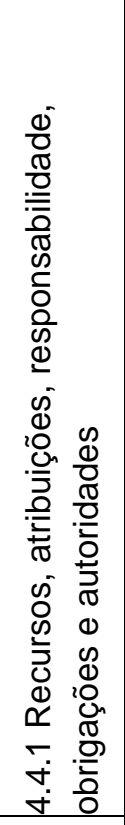 & 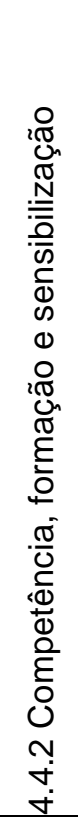 & 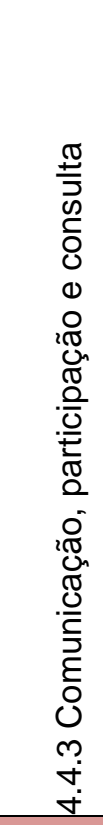 & 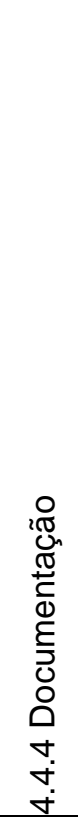 & 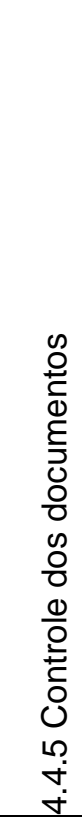 & 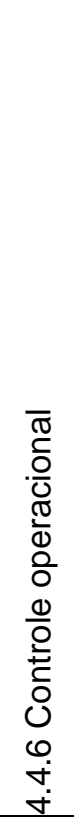 & 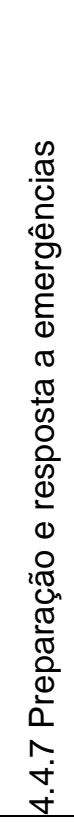 & 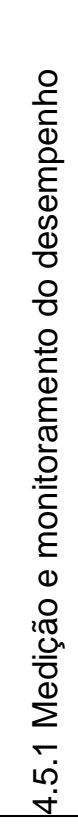 & 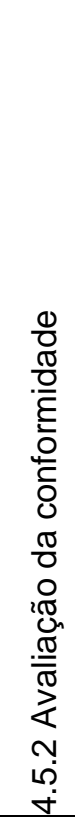 & 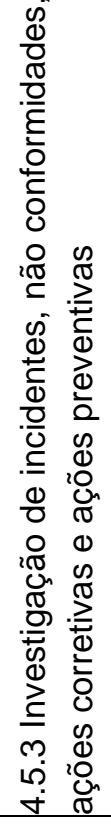 & 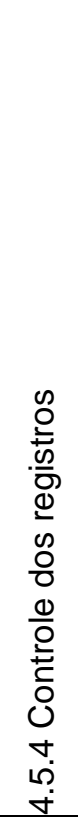 & 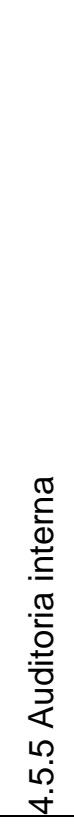 & 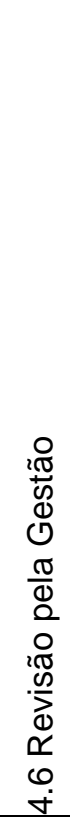 & 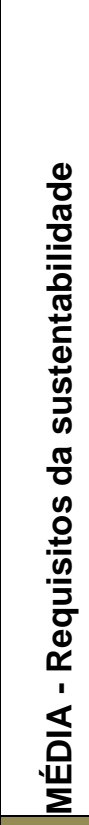 \\
\hline $\begin{array}{l}\text { 29. Adotar políticas para os ativos intangíveis (capital organizacional, capital } \\
\text { humano, capital de informação e capital reputacional) (ISE, 2013). }\end{array}$ & 0 & 3 & 0 & 0 & 0 & 0 & 0 & 3 & 0 & 0 & 0 & 0 & 0 & 0 & 0 & 0 & 0 & 0 & 0,33 \\
\hline $\begin{array}{l}\text { 30. Considerar os valores da defesa da concorrência em suas políticas } \\
\text { corporativas (ISE, 2013). }\end{array}$ & 0 & 0 & 3 & 0 & 0 & 0 & 0 & 0 & 0 & 0 & 0 & 0 & 0 & 0 & 0 & 0 & 0 & 0 & 0,17 \\
\hline $\begin{array}{l}\text { 31. Elaborar processos e procedimentos implementados de gestão de riscos } \\
\text { corporativos (risco estratégico, risco operacional, risco financeiro - mercado, } \\
\text { crédito e liquidez, risco reputacional e risco legal) que considerem aspectos } \\
\text { de curto, médio e longo prazo, acompanhados pelo Conselho de } \\
\text { Administração (ISE, 2013). }\end{array}$ & 0 & 0 & 0 & 0 & 0 & 0 & 0 & 0 & 0 & 0 & 0 & 0 & 0 & 0 & 0 & 0 & 0 & 0 & 0 \\
\hline $\begin{array}{l}\text { 32. Restringir o uso de instrumentos financeiros derivativos para fins } \\
\text { exclusivos de proteção (ISE, 2013). }\end{array}$ & 0 & 0 & 0 & 0 & 0 & 0 & 0 & 0 & 0 & 0 & 0 & 0 & 0 & 0 & 0 & 0 & 0 & 0 & 0 \\
\hline $\begin{array}{l}\text { 33. Implementar processos e procedimentos para monitorar impactos } \\
\text { econômicos indiretos das atividades da companhia (ISE, 2013). }\end{array}$ & 0 & 0 & 0 & 0 & 0 & 0 & 0 & 0 & 0 & 0 & 0 & 0 & 0 & 0 & 0 & 0 & 0 & 0 & 0 \\
\hline $\begin{array}{l}\text { 34. Elaborar processos e procedimentos implementados de gestão de ativos } \\
\text { intangíveis, além dos contabilizados (ISE, 2013). }\end{array}$ & 0 & 0 & 0 & 0 & 0 & 0 & 0 & 0 & 0 & 0 & 0 & 0 & 0 & 0 & 0 & 0 & 0 & 0 & 0 \\
\hline $\begin{array}{l}\text { 35. Possuir sistema de gestão de desempenho baseado em indicadores } \\
\text { vinculados ao planejamento estratégico (ISE, 2013). }\end{array}$ & 0 & 0 & 0 & 0 & 3 & 0 & 0 & 0 & 0 & 0 & 0 & 0 & 0 & 0 & 0 & 0 & 0 & 0 & 0,17 \\
\hline 36. Implantar medidas de defesa da concorrência (ISE, 2013). & 0 & 0 & 0 & 0 & 0 & 0 & 0 & 0 & 0 & 0 & 0 & 0 & 0 & 0 & 0 & 0 & 0 & 0 & 0 \\
\hline $\begin{array}{l}\text { 37. Preparar e publicar as demonstrações financeiras em moeda constante } \\
\text { (ISE, 2013) }\end{array}$ & 0 & 0 & 0 & 0 & 0 & 0 & 0 & 0 & 0 & 0 & 0 & 0 & 0 & 0 & 0 & 0 & 0 & 0 & 0 \\
\hline $\begin{array}{l}\text { 38. Calcular o lucro econômico ou outras medidas de geração de valor } \\
\text { econômico (ISE, 2013). }\end{array}$ & 0 & 0 & 0 & 0 & 0 & 0 & 0 & 0 & 0 & 0 & 0 & 0 & 0 & 0 & 0 & 0 & 0 & 0 & 0 \\
\hline $\begin{array}{l}\text { 39. Relatar o valor econômico direto (receitas) gerado e distribuído (custos } \\
\text { operacionais; salários e benefícios de empregados; pagamentos a } \\
\text { provedores de capital; pagamentos ao governo (por país); investimentos } \\
\text { comunitários), com base no regime de competência de exercícios (GRI). }\end{array}$ & 0 & 0 & 0 & 0 & 0 & 0 & 0 & 0 & 0 & 0 & 0 & 0 & 0 & 0 & 0 & 0 & 0 & 0 & 0 \\
\hline 40. Elaborar um plano de benefícios da organização (GRI). & 0 & 0 & 0 & 0 & 0 & 0 & 0 & 0 & 0 & 0 & 0 & 0 & 0 & 0 & 0 & 0 & 0 & 0 & 0 \\
\hline MÉDIA - Requisitos OHSAS 18001 & 0 & 0,25 & 0,25 & 0 & 0,3 & 0 & 0 & 0,3 & 0 & 0 & 0 & 0 & 0 & 0 & 0 & 0 & 0 & 0 & 0,06 \\
\hline
\end{tabular}


Apêndice 27. Matriz de Relação Consolidada OHSAS 18001 - Dimensão socioambiental.

\begin{tabular}{|c|c|c|c|c|c|c|c|c|c|c|c|c|c|c|c|c|c|c|c|}
\hline & 4.1 & 4.2 & 4 & & & & & & 4.4 & & & & & & 4.5 & & & 4.6 & \\
\hline $\begin{array}{l}\text { Requisitos da sustentabilidade } \\
\text { empresarial - Dimensão socioambiental }\end{array}$ & 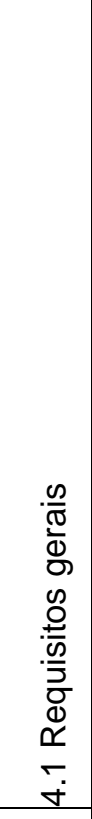 & 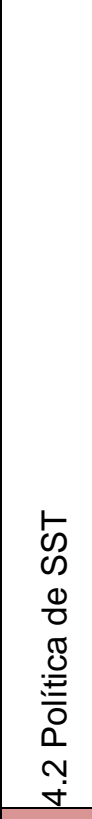 & 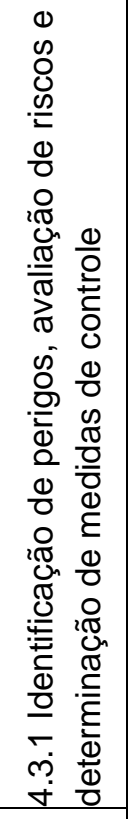 & 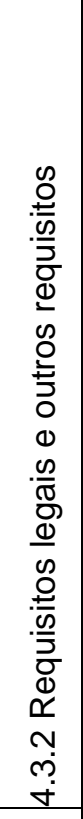 & 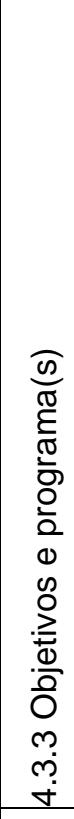 & 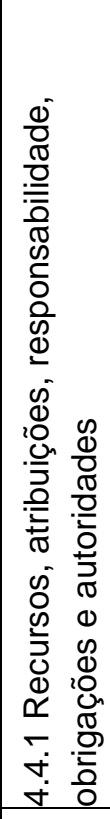 & 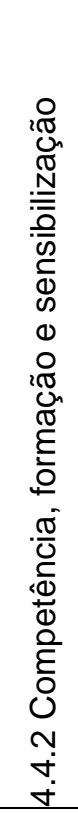 & 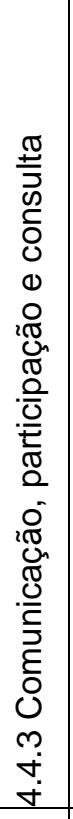 & 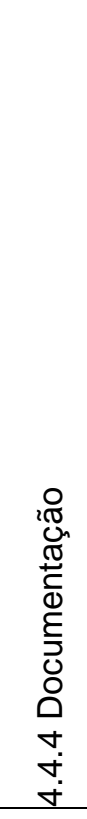 & 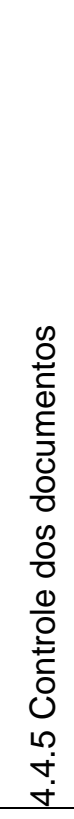 & 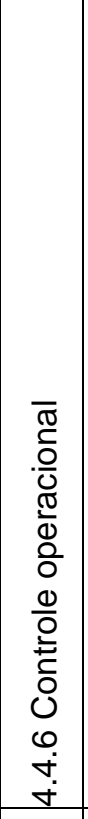 & 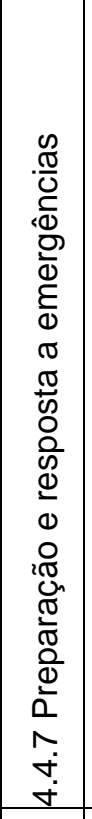 & 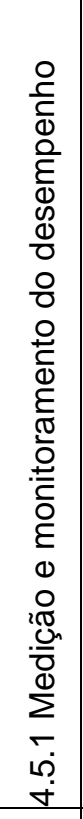 & 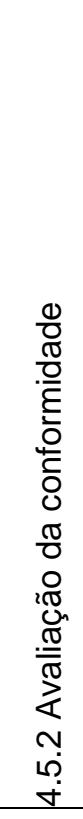 & 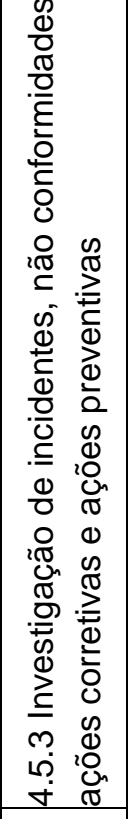 & 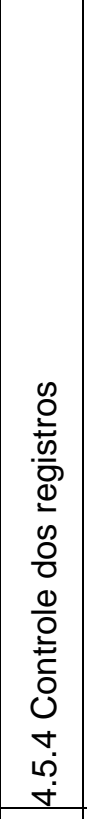 & 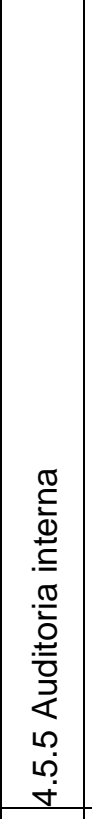 & 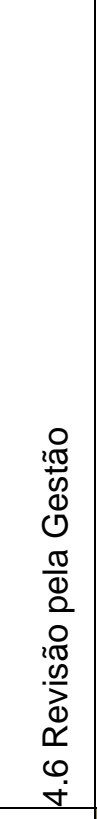 & 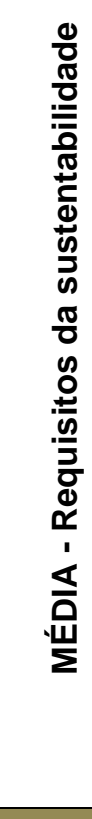 \\
\hline $\begin{array}{l}\text { 41. Comprometimento da alta direção com as questões socioambientais (Ethos, } \\
\text { 2013). }\end{array}$ & 0 & 3 & 0 & 0 & 0 & 0 & 0 & 0 & 0 & 0 & 0 & 0 & 0 & 0 & 0 & 0 & 0 & 0 & 0,17 \\
\hline $\begin{array}{l}\text { 42. Incorporar critérios socioambiental na estratégia da organização (Ethos, } \\
\text { 2013). }\end{array}$ & 0 & 0 & 0 & 0 & 0 & 0 & 0 & 0 & 0 & 0 & 0 & 0 & 0 & 0 & 0 & 0 & 0 & 0 & 0 \\
\hline $\begin{array}{l}\text { 43. Comunicar a toda a organização e outras partes interessadas a importância } \\
\text { de considerar os aspectos socioambientais (Ethos, 2013). }\end{array}$ & 0 & 0 & 0 & 0 & 0 & 0 & 0 & 0 & 0 & 0 & 0 & 0 & 0 & 0 & 0 & 0 & 0 & 0 & 0 \\
\hline $\begin{array}{l}\text { 44. A responsabilidade socioambiental deve ser repassada em toda a cadeia } \\
\text { produtiva (Ethos, 2013), (ISE, 2013) e (GRI). }\end{array}$ & 0 & 0 & 0 & 0 & 0 & 0 & 0 & 0 & 0 & 0 & 3 & 0 & 0 & 0 & 0 & 0 & 0 & 0 & 0,17 \\
\hline $\begin{array}{l}\text { 45. Possuir normas de seleção e avaliação de fornecedores que contemplam } \\
\text { critérios específicos de responsabilidade socioambiental (Ethos, 2013), (ISE, } \\
\text { 2013) e (GRI). }\end{array}$ & 0 & 0 & 0 & 0 & 0 & 0 & 0 & 0 & 0 & 0 & 3 & 0 & 0 & 0 & 0 & 0 & 0 & 0 & 0,17 \\
\hline $\begin{array}{l}\text { 46. Produzir relatórios periódicos com evidências de que questões relacionadas } \\
\text { à responsabilidade socioambiental empresarial estão sendo cumpridas e } \\
\text { implementadas em sua cadeia produtiva (Ethos, 2013). }\end{array}$ & 0 & 0 & 0 & 0 & 0 & 0 & 0 & 0 & 0 & 0 & 3 & 0 & 0 & 0 & 0 & 0 & 0 & 0 & 0,17 \\
\hline $\begin{array}{l}\text { 47. Caso necessário treinar os fornecedores para que se adequem as questões } \\
\text { relacionadas a responsabilidade socioambiental (Ethos, 2013) e (ISE, 2013). }\end{array}$ & 0 & 0 & 0 & 0 & 0 & 0 & 0 & 0 & 0 & 0 & 3 & 0 & 0 & 0 & 0 & 0 & 0 & 0 & 0,17 \\
\hline $\begin{array}{l}\text { 48. Participar de comitês/conselhos locais ou regionais para discutirem a questão } \\
\text { ambiental com o governo e a comunidade (Ethos, 2013). }\end{array}$ & 0 & 0 & 0 & 0 & 0 & 0 & 0 & 0 & 0 & 0 & 0 & 0 & 0 & 0 & 0 & 0 & 0 & 0 & 0 \\
\hline $\begin{array}{l}\text { 49. Desenvolver campanhas, apoiar ou participar de projetos educacionais em } \\
\text { parceria com organizações não governamentais e ambientalistas, exercendo } \\
\text { liderança social em favor dessa causa (Ethos, 2013). }\end{array}$ & 0 & 0 & 0 & 0 & 0 & 0 & 0 & 0 & 0 & 0 & 0 & 0 & 0 & 0 & 0 & 0 & 0 & 0 & 0 \\
\hline $\begin{array}{l}\text { 50. Disponibilizar suporte técnico aos consumidores finais com vistas ao uso } \\
\text { sustentável de seus produtos ou serviços (ISE, 2013). }\end{array}$ & 0 & 0 & 0 & 0 & 0 & 0 & 0 & 0 & 0 & 0 & 0 & 0 & 0 & 0 & 0 & 0 & 0 & 0 & 0 \\
\hline $\begin{array}{l}\text { 51. Fornecer aos consumidores e clientes informaç̃̃es detalhadas sobre danos } \\
\text { socioambientais resultantes do uso e na destinação final de seus produtos } \\
\text { (Ethos, 2013). }\end{array}$ & 0 & 0 & 0 & 0 & 0 & 0 & 0 & 0 & 0 & 0 & 0 & 0 & 0 & 0 & 0 & 0 & 0 & 0 & 0 \\
\hline $\begin{array}{l}\text { 52. Divulgar informações a respeito dos aspectos e impactos ambientais gerados } \\
\text { pela organização (ISE, 2013). }\end{array}$ & 0 & 0 & 0 & 0 & 0 & 0 & 0 & 0 & 0 & 0 & 0 & 0 & 0 & 0 & 0 & 0 & 0 & 0 & 0 \\
\hline $\begin{array}{l}\text { 53. Mecanismos de Queixas e Reclamações Relativas a Impactos Ambientais } \\
\text { (ISE, 2013) }\end{array}$ & 0 & 0 & 0 & 0 & 0 & 0 & 0 & 0 & 0 & 0 & 0 & 0 & 0 & 0 & 0 & 0 & 0 & 0 & 0 \\
\hline MÉDIA - Requisitos OHSAS 18001 & 0 & 0,23 & 0 & 0 & 0 & 0 & 0 & 0 & 0 & 0 & 0,9 & 0 & 0 & 0 & 0 & 0 & 0 & 0 & 0,06 \\
\hline
\end{tabular}


Apêndice 28. Matriz de Relação Consolidada OHSAS 18001 - Dimensão socioeconômica.

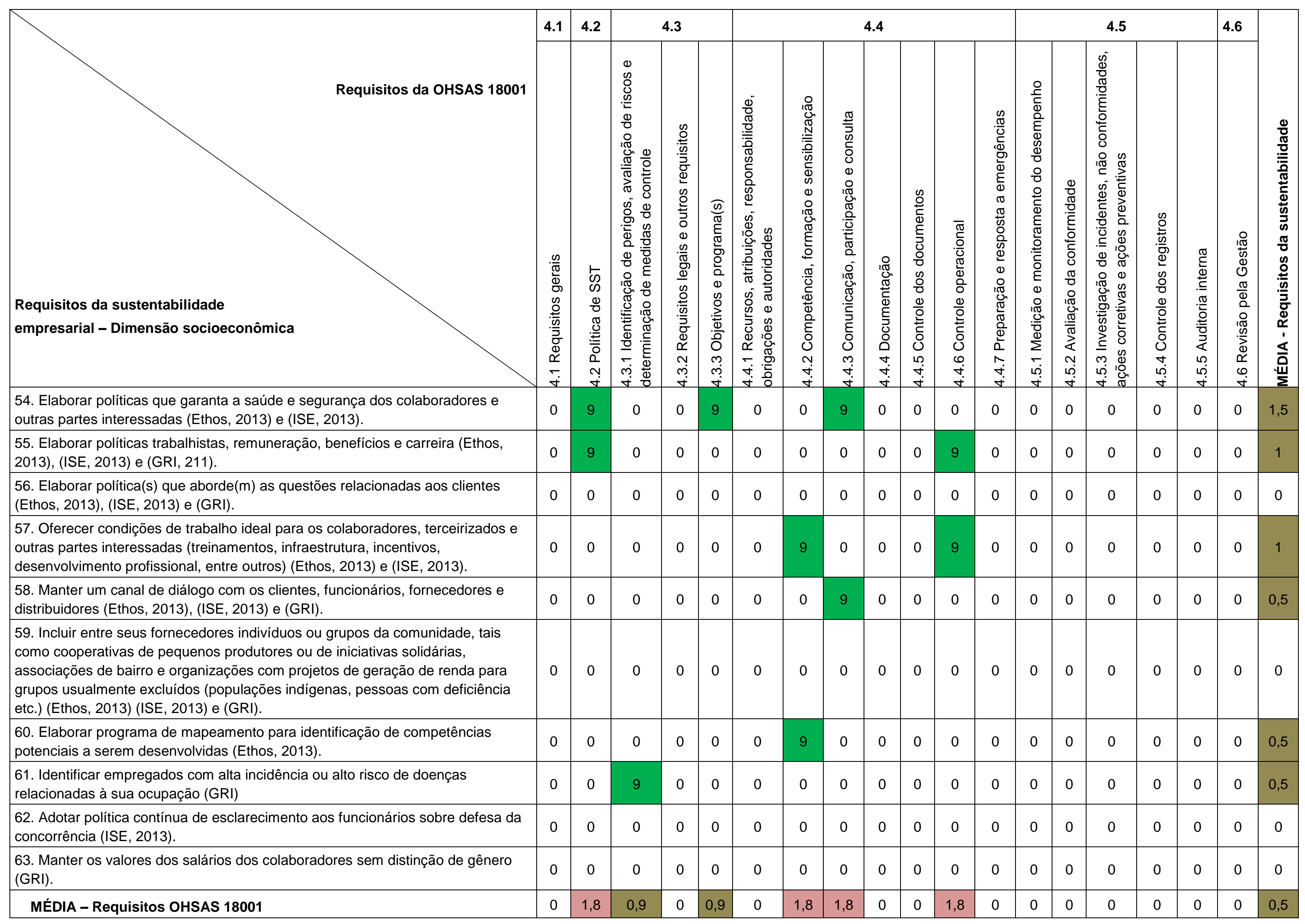


Apêndice 29. Matriz de Relação Consolidada OHSAS 18001 - Dimensão econômica - ambiental

\begin{tabular}{|c|c|c|c|c|c|c|c|c|c|c|c|c|c|c|c|c|c|c|c|}
\hline & 4.1 & 4.2 & & 4.3 & & & & & 4.4 & & & & & & 4.5 & & & 4.6 & \\
\hline $\begin{array}{l}\text { Requisitos da sustentabilidade } \\
\text { empresarial - Dimensão econômico-ambiental }\end{array}$ & 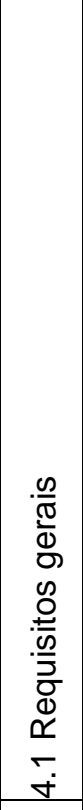 & 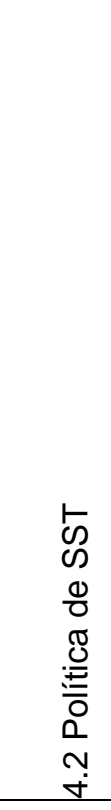 & 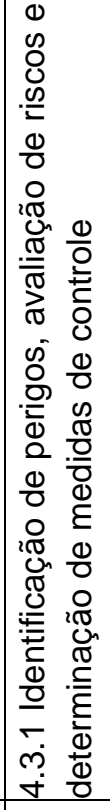 & 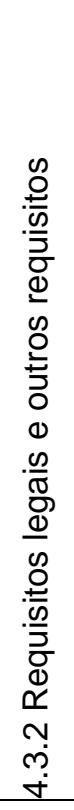 & 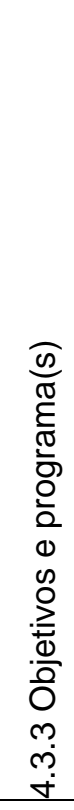 & 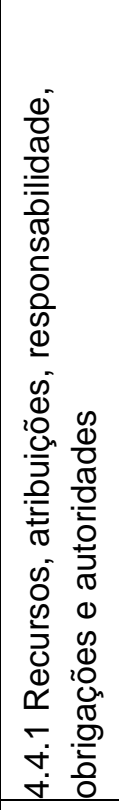 & 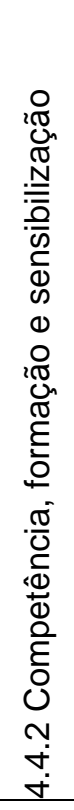 & 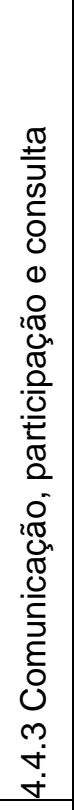 & 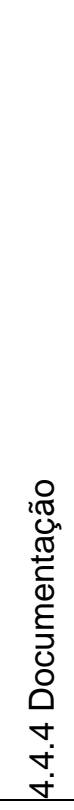 & 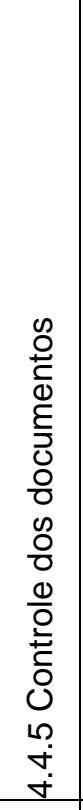 & 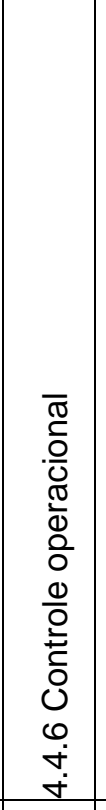 & 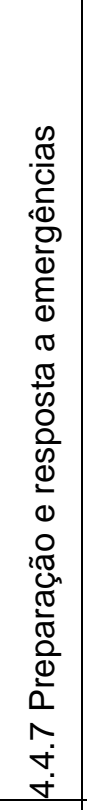 & 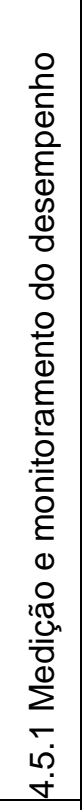 & 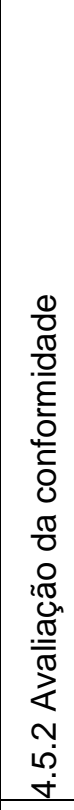 & 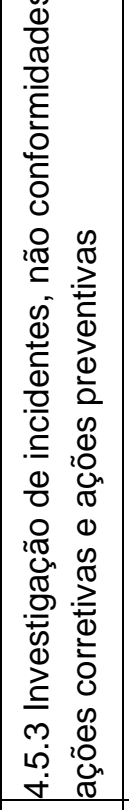 & 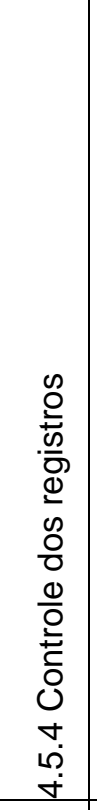 & 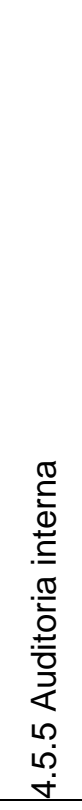 & 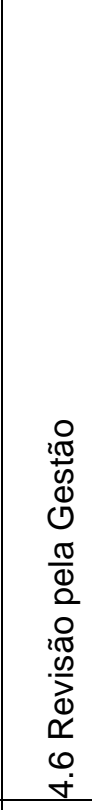 & 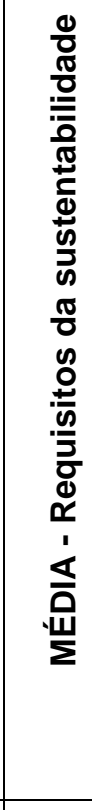 \\
\hline 64. Desenvolver programas internos de melhoramento ambiental (Ethos, 2013). & 0 & 0 & 0 & 0 & 0 & 0 & 0 & 0 & 0 & 0 & 0 & 0 & 0 & 0 & 0 & 0 & 0 & 0 & 0 \\
\hline 65. Possuir programas de gerenciamento de resíduos (Ethos, 2013). & 0 & 0 & 0 & 0 & 0 & 0 & 0 & 0 & 0 & 0 & 3 & 0 & 0 & 0 & 0 & 0 & 0 & 0 & 0,17 \\
\hline $\begin{array}{l}\text { 66. Possuir programas específicos para verificar a origem e a cadeia de } \\
\text { produção dos insumos madeireiros e florestais utilizados em sua operação diária } \\
\text { e/ou processo produtivo (Ethos, 2013). }\end{array}$ & 0 & 0 & 0 & 0 & 0 & 0 & 0 & 0 & 0 & 0 & 0 & 0 & 0 & 0 & 0 & 0 & 0 & 0 & 0 \\
\hline 67. Priorizar políticas preventivas (Ethos, 2013). & 0 & 9 & 9 & 0 & 0 & 0 & 0 & 0 & 0 & 0 & 9 & 9 & 0 & 0 & 0 & 0 & 0 & 0 & 2 \\
\hline $\begin{array}{l}\text { 68. Possuir políticas e sistema de monitoramento visando o aumento da } \\
\text { qualidade ambiental (Ethos, 2013). }\end{array}$ & 0 & 0 & 0 & 0 & 0 & 0 & 0 & 0 & 0 & 0 & 0 & 0 & 0 & 0 & 0 & 0 & 0 & 0 & 0 \\
\hline $\begin{array}{l}\text { 69. Participar da destinação final dos produtos e processos pós-consumo (Ethos, } \\
\text { 2013). }\end{array}$ & 0 & 0 & 0 & 0 & 0 & 0 & 0 & 0 & 0 & 0 & 0 & 0 & 0 & 0 & 0 & 0 & 0 & 0 & 0 \\
\hline $\begin{array}{l}\text { 70. Sem alterar seus padrões tecnológicos atuais, procurar reduzir o consumo de } \\
\text { energia, de água, de produtos tóxicos e de matérias-primas e implantar } \\
\text { processos para a destinação adequada de resíduos (Ethos, 2013). }\end{array}$ & 0 & 0 & 0 & 0 & 0 & 0 & 0 & 0 & 0 & 0 & 0 & 0 & 0 & 0 & 0 & 0 & 0 & 0 & 0 \\
\hline 71. Considerar os passivos ambientais (ISE, 2013). & 0 & 0 & 0 & 0 & 0 & 0 & 0 & 0 & 0 & 0 & 0 & 0 & 0 & 0 & 0 & 0 & 0 & 0 & 0 \\
\hline $\begin{array}{l}\text { 72. Possuir seguro para degradação ambiental decorrente de acidentes em suas } \\
\text { operações (ISE, 2013). }\end{array}$ & 0 & 0 & 0 & 0 & 0 & 0 & 0 & 0 & 0 & 0 & 0 & 0 & 0 & 0 & 0 & 0 & 0 & 0 & 0 \\
\hline 73. Considera a abordagem baseado no ciclo de vida dos produtos (ISE, 2013). & 0 & 0 & 0 & 0 & 0 & 0 & 0 & 0 & 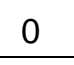 & 0 & 0 & 0 & 0 & 0 & 0 & 0 & 0 & 0 & 0 \\
\hline $\begin{array}{l}\text { 74. Possuir processo para medir, monitorar e auditar periodicamente os aspectos } \\
\text { ambientais significativos relacionados ao consumo de recursos naturais e à } \\
\text { produção de resíduos e dejetos, estabelecendo periodicamente novas metas } \\
\text { (Ethos, 2013), (ISE, 2013). }\end{array}$ & 0 & 0 & 0 & 0 & 0 & 0 & 0 & 0 & 0 & 0 & 0 & 0 & 0 & 0 & 0 & 0 & 0 & 0 & 0 \\
\hline 75. Monitorar o consumo de recursos naturais na cadeia produtiva (ISE, 2013). & 0 & 0 & 0 & 0 & 0 & 0 & 0 & 0 & 0 & 0 & 0 & 0 & 0 & 0 & 0 & 0 & 0 & 0 & 0 \\
\hline $\begin{array}{l}\text { 76. Considerar iniciativas tais como "ecodesign" ou DfE (Desing for Environment) } \\
\text { (ISE, 2013). }\end{array}$ & 0 & 0 & 0 & 0 & 0 & 0 & 0 & 0 & 0 & 0 & 0 & 0 & 0 & 0 & 0 & 0 & 0 & 0 & 0 \\
\hline $\begin{array}{l}\text { 77. As estratégias envolvendo a definição de produtos e/ou serviços oferecidos } \\
\text { pela companhia e/ou por suas controladas ou os projetos de Pesquisa e } \\
\text { Desenvolvimento elaborados pelas mesmas preveem planos para } \\
\text { reposicionamento (refere-se à mudança no mix de produtos/serviços do portfólio } \\
\text { e/ou público-alvo) em função das potenciais mudanças nos padrões de oferta e } \\
\text { demanda de recursos naturais (ISE, 2013). }\end{array}$ & 0 & 0 & 0 & 0 & 0 & 0 & 0 & 0 & 0 & 0 & 0 & 0 & 0 & 0 & 0 & 0 & 0 & 0 & 0 \\
\hline MÉDIA - Requisitos OHSAS 18001 & 0 & 0,64 & 0,64 & 0 & 0 & 0 & 0 & 0 & 0 & 0 & 0,86 & 0,6 & 0 & 0 & 0 & 0 & 0 & 0 & 0,15 \\
\hline
\end{tabular}


Apêndice 30. Matriz de Relação Consolidada OHSAS 18001 - Dimensão ambiental - social - econômica

\begin{tabular}{|c|c|c|c|c|c|c|c|c|c|c|c|c|c|c|c|c|c|c|c|}
\hline \multirow[b]{2}{*}{$\begin{array}{l}\text { Requisitos da OHSAS } 18001 \\
\text { empresarial - Dimensão ambiental - social - econômica da sustentabilidade } \\
\text { emproarial }\end{array}$} & \multirow[b]{2}{*}{ 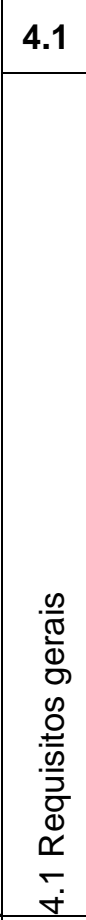 } & \multirow[b]{2}{*}{\begin{tabular}{|l|l}
4.2 \\
\\
\\
\\
\\
\end{tabular}} & \multicolumn{3}{|c|}{4.3} & \multicolumn{7}{|c|}{4.4} & \multicolumn{5}{|c|}{4.5} & \multirow[b]{2}{*}{ 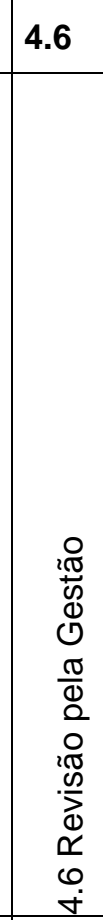 } & \multirow[b]{2}{*}{ 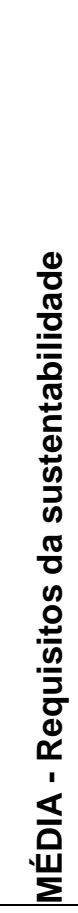 } \\
\hline & & & 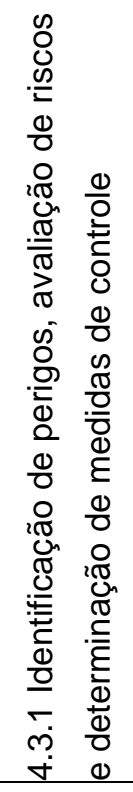 & 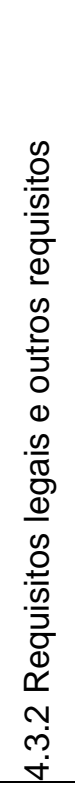 & 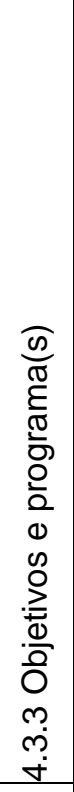 & 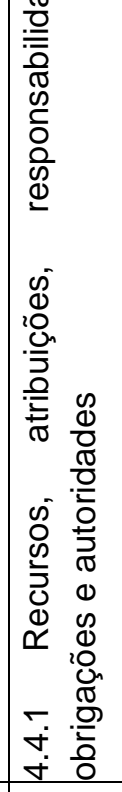 & 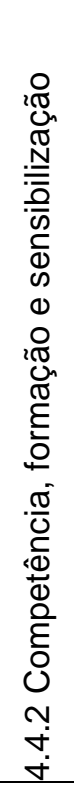 & 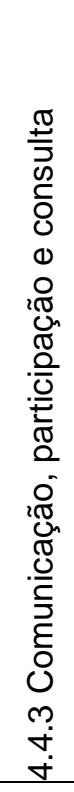 & 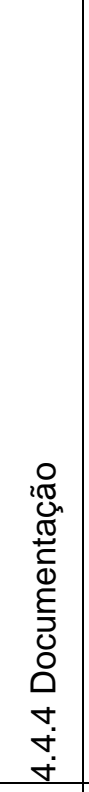 & 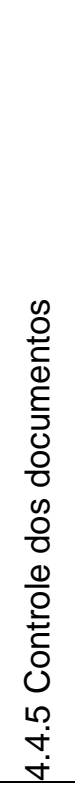 & $\begin{array}{l}\bar{\sigma} \\
\overline{0} \\
\frac{0}{0} \\
\frac{\pi}{0} \\
\frac{0}{0} \\
0 \\
0 \\
0 \\
0 \\
0 \\
0 \\
0 \\
\dot{0} \\
\dot{0}\end{array}$ & 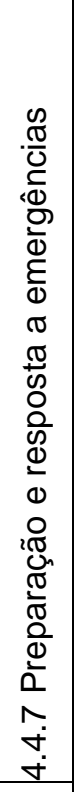 & 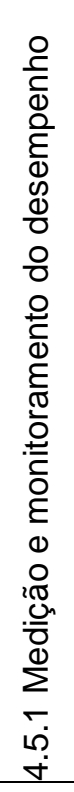 & 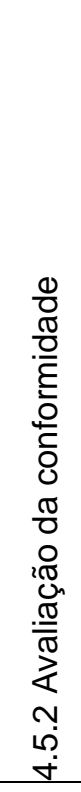 & 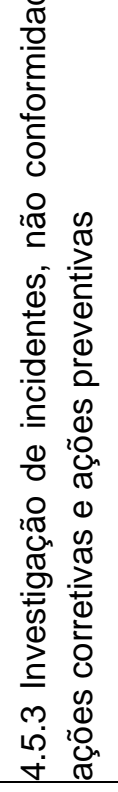 & 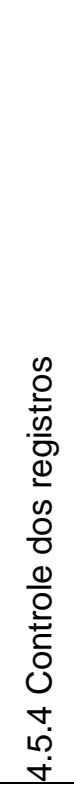 & 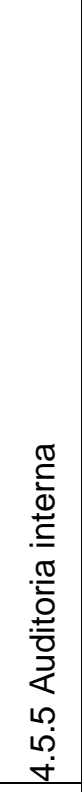 & & \\
\hline 78. Elaborar política de comunicação (Ethos, 2013). & 0 & 0 & 0 & 0 & 0 & 0 & 0 & 0 & 0 & 0 & 0 & 0 & 0 & 0 & 0 & 0 & 0 & 0 & 0 \\
\hline 79. Assumir uma postura ética (Ethos, 2013). & 0 & 0 & 0 & 0 & 0 & 0 & 0 & 0 & 0 & 0 & 0 & 0 & 0 & 0 & 0 & 0 & 0 & 0 & 0 \\
\hline $\begin{array}{l}\text { 80. Identificar as partes interessadas e conhecer o contexto em que cada parte } \\
\text { está inserida para que as mesmas possam auxiliar na mitigação dos impactos } \\
\text { socioambientais envolvidos em cada contexto (Ethos, 2013) e (ISE, 2013). }\end{array}$ & 0 & 0 & 0 & 0 & 0 & 0 & 0 & 0 & 0 & 0 & 0 & 0 & 0 & 0 & 0 & 0 & 0 & 0 & 0 \\
\hline $\begin{array}{l}\text { 81. Manter o diálogo com as partes interessadas (Ethos, 2013) (ISE, 2013) e } \\
\text { (GRI). }\end{array}$ & 0 & 0 & 0 & 0 & 0 & 0 & 0 & 0 & 0 & 0 & 0 & 0 & 0 & 0 & 0 & 0 & 0 & 0 & 0 \\
\hline $\begin{array}{l}\text { 82. Monitorar os impactos causados por suas atividades na comunidade de } \\
\text { entorno (Ethos, 2013). }\end{array}$ & 0 & 0 & 0 & 0 & 0 & 0 & 0 & 0 & 0 & 0 & 0 & 0 & 0 & 0 & 0 & 0 & 0 & 0 & 0 \\
\hline $\begin{array}{l}\text { 83. Possuir conselho ou responsável formal por questões éticas internas e } \\
\text { externas e garantir a gerência eficaz (Ethos, 2013) e (ISE, 2013). }\end{array}$ & 0 & 0 & 0 & 0 & 0 & 0 & 0 & 0 & 0 & 0 & 0 & 0 & 0 & 0 & 0 & 0 & 0 & 0 & 0 \\
\hline 84. Não praticar concorrência desleal (Ethos, 2013) e (GRI). & 0 & 0 & 0 & 0 & 0 & 0 & 0 & 0 & 0 & 0 & 0 & 0 & 0 & 0 & 0 & 0 & 0 & 0 & 0 \\
\hline 85. Cumprir a legislação e pagamentos de tributos (Ethos, 2013) e (ISE, 2013). & 0 & 0 & 0 & 0 & 0 & 0 & 0 & 0 & 0 & 0 & 0 & 0 & 0 & 0 & 0 & 0 & 0 & 0 & 0 \\
\hline 86. Comunicar o compromisso com o desenvolvimento sustentável (ISE, 2013). & 0 & 0 & 0 & 0 & 0 & 0 & 0 & 0 & 0 & 0 & 0 & 0 & 0 & 0 & 0 & 0 & 0 & 0 & 0 \\
\hline 87. Definir responsabilidades e autoridades (ISE, 2013). & 0 & 0 & 0 & 0 & 0 & 0 & 0 & 0 & 0 & 0 & 0 & 0 & 0 & 0 & 0 & 0 & 0 & 0 & 0 \\
\hline $\begin{array}{l}\text { 88. Existir processos e procedimentos implementados para gestão de } \\
\text { oportunidades corporativas que considere aspectos socioambientais de curto, } \\
\text { médio e longo prazo (ISE, 2013). }\end{array}$ & 0 & 0 & 0 & 0 & 0 & 0 & 0 & 0 & 0 & 0 & 0 & 0 & 0 & 0 & 0 & 0 & 0 & 0 & 0 \\
\hline $\begin{array}{l}\text { 89. Possuir plano de contigência que considere desastres naturais, impactos } \\
\text { ambientais, impactos sociais, impactos em infraestrutura/operacionais (incluindo } \\
\text { TI) (ISE, 2013). }\end{array}$ & 0 & 0 & 0 & 0 & 0 & 0 & 0 & 0 & 0 & 0 & 0 & 0 & 0 & 0 & 0 & 0 & 0 & 0 & 0 \\
\hline MÉDIA - Requisitos OHSAS 18001 & 0 & 0 & 0 & 0 & 0 & 0 & 0 & 0 & 0 & 0 & 0 & 0 & 0 & 0 & 0 & 0 & 0 & 0 & 0 \\
\hline
\end{tabular}

